\title{
Regulação e Universalização dos Serviços de Água e Esgoto: Estudo do Nordeste Brasileiro
}

\section{Alceu de Castro Galvão Junior}

Tese apresentada ao Programa de PósGraduação em Saúde Pública da Faculdade de Saúde Pública da Universidade de São Paulo para obtenção do título de Doutor em Saúde Pública.

Área de Concentração: Saúde Ambiental

Orientador: Prof. Dr. Wanderley da Silva Paganini

São Paulo

2008

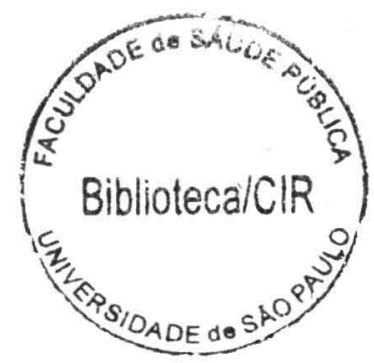


É expressamente proibida a comercialização deste documento tanto na sua forma impressa como eletrônica. Sua reprodução total ou parcial é permitida exclusivamente para fins acadêmicos e científicos, desde que na reprodução figure a identificação do autor, título e ano da tese.

$$
49676 / 2008 \text { doc }
$$




\section{DEDICATÓRIA}

À minha família pelo incansável apoio, incentivo, companheirismo, amor e carinho ao longo desta jornada 


\section{AGRADECIMENTOS}

A minha família, Alceu, Marli, André, Natália e Alcélia, pelo apoio, carinho, compreensão e paciência ao longo de minha jornada.

Ao Professor Wanderley Paganini, pelo apoio, clareza e objetividade durante a orientação do curso de doutorado.

Aos Professores Fred Turolla e José Carlos Araújo, pelas contribuições que tanto enriqueceram este trabalho.

Ao Paulo, Paula Jorge, Glória, Sandra Nishio, Beatriz, Lucélia e Rafael, pela amizade e convivência na Pós-Graduação.

Aos professores e funcionários do Departamento de Saúde Ambiental e da Faculdade de Saúde Pública, pela convivência e aprendizado em aula.

Ao Conselho Diretor da ARCE, na pessoa da Marfisa Ximenes, pela confiança e apoio durante o doutorado.

Aos companheiros da Coordenadoria de Saneamento Básico, Alexandre, Geraldo, Marcio, Danúbio, Cristina e Vinícius, pelo apoio durante meu afastamento da ARCE.

As agências reguladoras ARCE, ARSAL, ARSBAN, ARPE e ARPB, além da ABAR, pela contribuição nas entrevistas.

A Maria do Céu e ao Lúcio pelo apoio no desenvolvimento desta tese.

Ao grupo da orientação coletiva do Prof. Wanderley, Patrícia, Miriam, Camila, Ana Paula, Cláudia, Carlos Roberto, pelo apoio durante esta jornada.

A Fundação Cearense de Apoio ao Desenvolvimento Científico e Tecnológico (FUNCAP), pela bolsa de Doutorado concedida. 


\section{RESUMO}

GALVÃo JUNIOR, A. C. - Regulação e Universalização dos Serviços de Água e Esgoto: Estudo do Nordeste Brasileiro [tese de doutorado]. São Paulo: Faculdade de Saúde Pública da USP, 2008.

Introdução - Considerando o contexto da provisão dos serviços de água e esgoto na região Nordeste, é de se esperar que a regulação assuma papel fundamental na melhoria e na universalização da prestação dos serviços. Objetivo - Analisar as experiências regulatórias para a prestação dos serviços de água e esgoto no Nordeste brasileiro e oferecer subsídios para elaboração e aperfeiçoamento de modelos regulatórios pró-universalização. Metodologia - Os procedimentos técnicos utilizados foram as pesquisas bibliográfica e documental, assim como a entrevista. $\mathrm{O}$ objeto da pesquisa foi a regulação dos serviços de água e esgoto na região Nordeste e as agências reguladoras estaduais. Resultados e Discussão - Foram observados problemas de natureza institucional na maioria das agências reguladoras estudadas, resultado da existência de instrumentos precários para regulação e da ausência de cooperação institucional entre agências reguladoras e municípios para o exercício desta atividade. Não obstante estes problemas, as experiências em andamento têm criado incentivos no sentido de ganhos de eficiência nas empresas reguladas, mesmo de forma incipiente, o que contribui para a busca da universalização dos serviços. Em função deste quadro, é indicado comportamento evolutivo das agências assim como proposição de arranjos institucionais entre agências estaduais e municípios para regulação dos serviços. Conclusão - Neste contexto, os marcos regulatórios subnacionais e sua implementação permitirão definir mecanismos concretos para o desempenho adequado da regulação e de seus entes. Assim, ante aos diferentes pontos abordados nesta pesquisa, entende-se que no desenvolvimento da regulação setorial devem ser consideradas os seguintes aspectos: gradatividade e sustentabilidade da atividade regulatória, aproveitamento das capacidades instaladas, modelos regulatórios adaptáveis as diferentes realidades locais e regionais e fortalecimento institucional do ente regulador.

Descritores: Regulação, Agências Reguladoras, Universalização, Saneamento Básico. 


\begin{abstract}
GALVÃO JUNIOR, A. C. - Regulation and Universal Access of Water and Sewage Services: Study of Northeastern Region of Brazil [Thesis]. São Paulo (BR): Faculty of Public Health of University of São Paulo, 2008.

Introduction - Considering the context of the provision of the water and sewage services in the Northeast region of Brazil, it is expected that regulation assumes fundamental role for the improvement and the universal access of this services. Objective - Analyze the regulatory experiences in the Northeast region and offer subsidies for elaboration and improvement of the regulatory models. Methodology The technical procedures used were the bibliographic and documentary research, as well as the interview. The object of the research was the regulation of the water and sewage services in the Northeast region and its state regulatory agencies. Results and Discussion - It was observed institutional problems in most of the agencies, resulted from the existence of precarious instruments to regulation and the absence of institutional cooperation between regulatory agencies and the municipalities for the exercise of the regulation. Instead these problems, the experiences underway have created incentives for the companies to gain efficiency, even in a incipient form, that contributes to the universal access of the services. In function of this frame, it is indicated an evolutionary behavior of the agencies as well as a proposition of institutional arrangements between state agencies and municipalities to regulation of the services. Conclusion - In this context, the sub-national framework and its implementation will permit to define concrete mechanism for the adequate performance of the regulation and its entities. In face of the different points discussed in this research, the development of the regulation needs to consider these aspects: gradation and sustainability of the regulatory activity, use of the installed abilities, regulatory models adaptable to the different local and regional realities and institutional strengthening of the regulator.
\end{abstract}

Descriptors: Regulation, Regulatory Agencies, Universal Access, Basic Sanitation. 


\section{ÍNDICE}

1 INTRODUÇÃO 18

1.1 FORMULAÇÃO DO PROBLEMA 18

1.2 OBJETIVOS 23

1.2.1 Geral $\quad 23$

1.2.2 Específicos 23

2 METODOLOGIA 24

2.1 OBJETO DA PESQUISA 24

2.2 PESQUISA BIBLIOGRÁFICA E DOCUMENTAL 27

2.3 ENTREVISTAS 28

2.4 REGIÃO NORDESTE $\quad 30$

2.4.1 Características Gerais $\quad 30$

2.4.2 Situação do Saneamento Básico 31

3 REVISÃO DA LITERATURA 39

3.1 UNIVERSALIZAÇÃO DOS SERVIÇOS DE ÁGUA E 39 ESGOTO

3.1.1 Padrões de Atendimento 49

3.1.2 Mecanismos de Políticas Públicas de Universalização $\quad 52$

3.1.3 Desafios para a Universalização 55

3.2 REGULAÇÃO $\quad 62$

3.2.1 Origem da Regulação $\quad 62$

3.2.2 Teorias sobre a Regulação $\quad 67$

3.2.3 Propriedade Estatal $\quad 71$

3.2.4 Políticas de Estado, de Governo e Regulatória $\quad 74$

3.2.5 Regulação - Eficiência e Equidade $\quad 80$

3.2.6 Formas de Regulação $\quad 82$

3.3 AGÊNCIAS REGULADORAS $\quad 94$

3.3.1 Desenho Regulatório $\quad 94$ 
3.3.1.1 Independência da agência

3.3.1.2 Mandatos dos dirigentes

3.3.1.3 Participação e controle social 97

3.3.1.4 Decisão colegiada $\quad 99$

3.3.1.5 Tecnicidade e quadro de pessoal $\quad 100$

3.3.2 Marco Regulatório e Agências 101

3.3.3 Agências Reguladoras no Brasil 102

3.4 REGULAÇÃO DO SETOR DE ÁGUA E ESGOTO 109

3.4.1 Características do Setor de Água e Esgoto 109

3.4.2 Regulação Suprasetorial 112

4. REGULAÇÃo dOS SERVIÇOS DE ÁGUA E ESGOTO 119 NO NORDESTE BRASILEIRO

4.1. MODELO REGULATÓRIO NA LEI N ${ }^{0} 11.445 / 2007$

4.2. OPERACIONALIZAÇÃO DA REGULAÇÃO DO SETOR 126 DE ÁGUA E ESGOTO

4.3. REGULAÇÃO NO NORDESTE BRASILEIRO 131

4.3.1 Agência Reguladora do Estado da Paraíba 132

4.3.2 Agência Reguladora de Serviços Públicos do Estado de 134 Alagoas

4.3.3 Agência Reguladora de Serviços Públicos Delegados do Estado do Ceará

4.3.4 Agência de Regulação dos Serviços Públicos Delegados 145 do Estado de Pernambuco

4.3.5 Agência Reguladora de Serviços de Saneamento Básico do 148 Município de Natal (RN)

4.3.6 Considerações Gerais

4.3.6.1 Universalização

4.3.6.2 Poder de recomendação

4.3.6.3 Vinculação administrativa 
4.3.6.4 Quadro de pessoal próprio

4.3.6.5 Indicação dos quadros intermediários

4.3.6.6 Falta de instrumentos efetivos de sanção

4.3.6.7 Evolução institucional

4.3.6.8 Arranjos para a regulação dos serviços

4.3.6.9 Parcerias intersetoriais

4.3.6.10 Quadro-resumo

5. ESTRUTURA PARA O MODELO REGULATÓRIO 161

5.1. EVOLUÇÃO INSTITUCIONAL 161

5.2 COOPERAÇÃO INSTITUCIONAL ENTRE AGÊNCIAS 165 REGULADORAS ESTADUAIS E MUNICÍPIOS

6 CONCLUSÃO

7 RECOMENDAÇÕES

8 REFERÊNCIAS

\section{ANEXO}

Anexo 1 - Roteiro da entrevista com os reguladores 


\section{Lista de Figuras}

Figura 1 - Cobertura dos serviços de água e esgoto por redes nos 32 estados da região Nordeste

Figura 2A - Cobertura de rede de água por classe de rendimento mensal $\quad 34$ domiciliar nos Estados da região Nordeste

Figura 2B - Cobertura de rede de esgoto por classe de rendimento mensal domiciliar nos Estados da região Nordeste

Figura 3 - Impactos negativos da ausência de saneamento básico nos recursos hídricos, meio ambiente e atividades humanas

Figura 4 - Algumas tecnologias para universalização dos serviços de 48 água e esgoto e etapas de implementação

Figura 5A - Distribuição no acesso de água por rede geral dos domicílios brasileiros segundo renda, região e localização

Figura 5B - Distribuição no acesso ao esgotamento sanitário por rede geral dos domicílios brasileiros segundo renda, região e localização

Figura 6 - Acesso aos serviços de infra-estrutura no país (1970-2005) 58

Figura 7 - Evolução das políticas sociais, de saneamento básico e de 61 infra-estrutura

Figura 8 - Pressupostos para intervenção do Estado na economia 66

Figura 9 - Políticas de Estado, governamental e regulatória 76

Figura 10 - Configurações dos setores de energia e saneamento básico 84

Figura 11 - Principais variáveis para definição da forma de regulação dos 90 serviços públicos de infra-estrutura

Figura 12A - Principais variáveis para definição da forma de regulação no setor de telecomunicações

Figura 12B - Principais variáveis para definição da forma de regulação no setor de saneamento básico

Figura 13 - Leis de criação das agências reguladoras brasileiras

Figura 14 - Mapa de atuação das agências reguladoras brasileiras 
Figura 15 - Interfaces da regulação da prestação dos serviços de 113 abastecimento de água com a regulação intersetorial

Figura 16 - Interfaces da regulação da prestação dos serviços de 115 esgotamento e tratamento de esgotos com a regulação intersetorial

Figura 17 - Interfaces da regulação da prestação dos serviços de 116 comercialização dos serviços de saneamento básico com a regulação intersetorial

$\begin{array}{lll}\text { Figura } 18 \text { - Organograma da ARPB } & 134\end{array}$

$\begin{array}{lll}\text { Figura } 19-\text { Organograma da ARSAL } & 138\end{array}$

$\begin{array}{lll}\text { Figura } 20 \text { - Organograma da ARCE } & 141\end{array}$

$\begin{array}{lll}\text { Figura } 21 \text { - Organograma da ARPE } & 146\end{array}$

$\begin{array}{lll}\text { Figura } 22 \text { - Organograma da ARSBAN } & 150\end{array}$

Figura 23 - Proposição de evolução institucional das agências 162 reguladoras estaduais de saneamento básico 


\section{Lista de Quadros}

Quadro 1 - Legislação relevante para a universalização dos serviços de 41 água e esgoto

Quadro 2 - Padrões de atendimento para universalização dos serviços de 50 água e esgoto

Quadro 3 - Padrão de universalização da OMS e do UNICEF 51

Quadro 4 - Políticas e papéis do Estado, governo e regulador na 78 universalização do setor de telecomunicações

Quadro 5 - Características dos principais métodos de regulação de 85 preços

Quadro 6 - Regulação da qualidade de serviços públicos de infra- 87 estrutura

Quadro 7 - Principais características e desvantagens das formas de 89 regulação

Quadro 8 - Características do setor de saneamento e suas repercussões 109

Quadro 9 - Funções do titular e do regulador previstas na Lei $\mathrm{n}^{\circ} 120$ $11.445 / 2007$

Quadro 10 - Taxas de regulação das agências com competência para atuar 122 no saneamento básico

Quadro 11 - Considerações gerais e específicas das atividades de 128 fiscalização, normatização, regulação econômica e ouvidoria

Quadro 12 - Arranjos de cooperação entre a ARCE, governo estadual e 143 municípios para regulação no Estado do Ceará

Quadro 13 - Resumo das revisões tarifárias da CAERN

Quadro 14 - Resumo das características gerais das agências reguladoras 159 do Nordeste brasileiro

Quadro 15 - Arranjos de cooperação entre agências reguladoras estaduais 166 e municípios para regulação dos serviços de água e esgoto 


\section{Lista de Tabelas}

Tabela 1 - Características demográficas e fiscais dos municípios 31 nordestinos

Tabela 2 - Características gerais das companhias estaduais de 37 saneamento básico da região Nordeste

Tabela 3 - Investimentos para universalização dos serviços de água e 50 esgoto no Brasil 


\section{Siglas Utilizadas}

AAGISA - Agência de Águas, Irrigação e Saneamento do Estado da Paraíba

ABAR — - Associação Brasileira das Agências de Regulação

ABCON - Associação Brasileira das Concessionárias de Serviços Públicos de Água e Esgoto

ABDIB - $\quad$ Associação Brasileira das Indústrias de Base

ABES — - Associação Brasileira de Engenharia Sanitária e Ambiental

ADASA - Agência Reguladora de Águas e Saneamento do Distrito Federal

ADIN — - Ação Direta de Inconstitucionalidade

AESA — Agência Executiva de Gestão das Águas do Estado da Paraíba

AESBE — - Associação das Empresas de Saneamento Básico Estaduais

AGEAC - Agência Reguladora dos Serviços Públicos do Estado do Acre

AGENERSA - Agência Reguladora de Energia e Saneamento do Estado do Rio de Janeiro

AGENREG - Agência de Regulação dos Serviços Públicos Delegados de Campo Grande

AGEPAN - Agência Estadual de Regulação de Serviços Públicos do Mato Grosso do Sul

AGER - Agência Estadual de Regulação dos Serviços Públicos Delegados do Estado do Mato Grosso

AGERBA - Agência de Regulação de Serviços Públicos de Energia, Transportes e Comunicações da Bahia

AGERGS - Agência Estadual de Regulação dos Serviços Públicos Delegados do Rio Grande do Sul

AGERSA - Agência Municipal de Regulação de Serviços de Saneamento de Cachoeiro do Itapemirim (ES)

AGESAN - Agência Estadual de Saneamento do Tocantins

AGESC - Agência Reguladora de Serviços Públicos de Santa Catarina

AGESPISA - Companhia de Água e Esgoto do Piauí 


\begin{tabular}{|c|c|c|}
\hline AGETRANSP & - & $\begin{array}{l}\text { Agência Estadual de Serviços Públicos Concedidos de } \\
\text { Transportes Aquaviários, Ferroviários e Metroviários e de } \\
\text { Rodovias do Estado do Rio de Janeiro }\end{array}$ \\
\hline AGR & - & $\begin{array}{l}\text { Agência Goiana de Regulação, Controle e Fiscalização de } \\
\text { Serviços Públicos }\end{array}$ \\
\hline AMAE & - & Agência Municipal de Água e Esgotos (Joinville - SC) \\
\hline ANA & - & Agência Nacional de Águas \\
\hline ANATEL & - & Agência Nacional de Telecomunicações \\
\hline ANCINE & - & Agência Nacional do Cinema \\
\hline ANEEL & - & Agência Nacional de Energia Elétrica \\
\hline ANP & - & Agência Nacional do Petróleo \\
\hline ANS & - & Agência Nacional de Saúde Complementar \\
\hline ANTAQ & - & Agência Nacional de Transportes Aquaviários \\
\hline ANTT & - & Agência Nacional de Transportes Terrestres \\
\hline ANVISA & - & Agência Nacional de Vigilância Sanitária \\
\hline ARCE & - & $\begin{array}{l}\text { Agência Reguladora de Serviços Públicos Delegados do } \\
\text { Estado do Ceará }\end{array}$ \\
\hline ARCON & - & $\begin{array}{l}\text { Agência Estadual de Regulação e Controle dos Serviços } \\
\text { Públicos do Pará }\end{array}$ \\
\hline ARPB & - & Agência Reguladora do Estado da Paraíba \\
\hline ARPE & - & $\begin{array}{l}\text { Agência de Regulação dos Serviços Públicos Delegados do } \\
\text { Estado de Pernambuco }\end{array}$ \\
\hline ARSAE & - & $\begin{array}{l}\text { Agência Reguladora dos Serviços de Água e Esgoto } \\
\text { (Mauá/SP) }\end{array}$ \\
\hline ARSAL & - & $\begin{array}{l}\text { Agência Reguladora de Serviços Públicos do Estado de } \\
\text { Alagoas }\end{array}$ \\
\hline ARSAM & - & $\begin{array}{l}\text { Agência Reguladora dos Serviços Públicos Concedidos do } \\
\text { Estado do Amazonas }\end{array}$ \\
\hline ARSBAN & - & $\begin{array}{l}\text { Agência Reguladora de Serviços de Saneamento Básico do } \\
\text { Município de Natal (RN) }\end{array}$ \\
\hline ARSEP & - & Agência Reguladora de Serviços Públicos do Rio Grande do \\
\hline
\end{tabular}


Norte

ARSESP - Agência Reguladora de Saneamento e Energia do Estado de São Paulo

ARTESP - Agência Reguladora de Serviços Públicos Delegados de Transporte do Estado de São Paulo

ASEP - Agência Reguladora de Serviços Públicos Concedidos do Estado do Rio de Janeiro

ASPE - Agência de Serviços Públicos de Energia do Estado do Espírito Santo

ASSEMAE - Associação Nacional dos Serviços Municipais de Saneamento

ATR - Agência Tocantinense de Regulação, Controle e Fiscalização dos Serviços Públicos

BID _ - Banco Interamericano de Desenvolvimento

BIRD _ - Banco Internacional de Reconstrução e Desenvolvimento

BNDES _ - Banco Nacional de Desenvolvimento Econômico e Social

CADE - Conselho Administrativo de Defesa da Concorrência

CAEMA — Companhia de Água e Esgotos do Maranhão

CAERN - Companhia de Água e Esgotos do Rio Grande do Norte

CAGECE - Companhia de Água e Esgotos do Ceará

CAGEPA - Companhia de Água e Esgotos da Paraíba

CASAL - Companhia de Abastecimento D'Água e Saneamento de Alagoas

CEPAL - Comissão Econômica para a América Latina e o Caribe

CESB — Companhia Estadual de Saneamento Básico

COMPESA - Companhia Pernambucana de Saneamento

COMSAB - Conselho Municipal de Saneamento Básico

CSPE - Comissão de Serviços Públicos de Energia (SP)

DEC - - Duração Equivalente de Interrupção por Unidade Consumidora

DIC _ - Duração de Interrupção Individual por Unidade Consumidora ou por Ponto de Conexão

DMCI - Duração Máxima de Interrupção Contínua por Unidade 


\begin{tabular}{|c|c|c|}
\hline & & Consumidora ou por Ponto de Conexão \\
\hline DESO & - & Companhia de Saneamento de Sergipe \\
\hline EMBASA & - & Empresa Baiana de Águas e Saneamento \\
\hline FMI & - & Fundo Monetário Internacional \\
\hline FUNASA & - & Fundação Nacional de Saúde \\
\hline FUST & - & Fundo de Universalização dos Serviços de Telecomunicações \\
\hline IBGE & - & Instituto Brasileiro de Geografia e Estatística \\
\hline IGARN & - & $\begin{array}{l}\text { Instituto de Gestão das Águas do Estado do Rio Grande do } \\
\text { Norte }\end{array}$ \\
\hline IMA & - & Instituto do Meio Ambiente \\
\hline IPEA & - & $\begin{array}{l}\text { Instituto de Pesquisas e Economia Aplicada do Governo } \\
\text { Federal }\end{array}$ \\
\hline NARUC & - & National Association of Regulatory Utilities Comission \\
\hline OFWAT & - & Water Services Regulation Authority \\
\hline OGU & - & Orçamento Geral da União \\
\hline OMS & - & Organização Mundial da Saúde \\
\hline ONU & - & Organização das Nações Unidas \\
\hline OPAS & - & Organização Pan-Americana de Saúde \\
\hline PBGÁS & - & Companhia Paraibana de Gás \\
\hline PCS & - & Plano de Cargos e Salários \\
\hline PLANASA & - & Plano Nacional de Saneamento \\
\hline PMSS & - & Programa de Modernização do Setor de Saneamento \\
\hline PNAD & - & Pesquisa Nacional por Amostra de Domicílios \\
\hline PNSB & - & Pesquisa Nacional de Saneamento Básico \\
\hline SEMPLA & - & Secretaria Municipal de Planejamento \\
\hline SNIS & - & Sistema Nacional de Informações sobre Saneamento \\
\hline STF & - & Supremo Tribunal Federal \\
\hline SUS & - & Sistema Único de Saúde \\
\hline TUP & - & Telefone de Uso Público \\
\hline UNICEF & - & Fundo das Nações Unidas para a Infância \\
\hline UPF & - & Unidade Padrão Fiscal do Estado do Rio Grande do Sul \\
\hline
\end{tabular}




\section{INTRODUÇÃO}

\subsection{FORMULAÇÃO DO PROBLEMA}

O acesso aos serviços de saneamento básico é condição fundamental para a sobrevivência e a dignidade da pessoa humana. $\mathrm{O}$ déficit em saneamento básico traz conseqüências graves em termos de saúde pública, meio ambiente e cidadania (GLEICK, 1999; HELLER et al., 2003; HUTTON e HALLER, 2004; SOARES et al., 2002; TEIXEIRA e PUNGIRUM, 2005).

De acordo com o relatório mundial de saúde da OMS, estima-se que em 2007 exista cerca de 1,1 bilhão de pessoas sem acesso à água segura e 2,6 bilhões sem saneamento adequado (OMS, 2007). Isto contribui diariamente para a morte de 4.500 crianças no mundo por doenças de veiculação hídrica perfeitamente evitáveis, como a diarréia (Id. Ibid.).

A Organização das Nações Unidas estabeleceu como meta $^{1}$ a redução pela metade, até 2015 , da proporção da população sem acesso permanente e sustentável à água potável e ao saneamento (ONU, 2005). Apesar dos esforços de muitos governos de países em desenvolvimento, somente a América Latina e o Caribe apresentam perspectiva para atendimento integral da meta (ONU, 2007).

No Brasil, o déficit do setor de saneamento básico é elevado, sobretudo no que se refere ao esgotamento e tratamento de esgotos, com maior carência nas áreas periféricas dos centros urbanos e nas zonas rurais, onde está concentrada a população mais pobre.

Em relação às regiões brasileiras, o Nordeste do Brasil se caracteriza por ser uma das mais deficitárias em termos de infra-estrutura de água e de esgoto. Conforme o censo do Instituto Brasileiro de Geografia e Estatística de 2000, dos 45 milhões de domicílios brasileiros, 35 milhões estavam conectados à rede de distribuição de água, 7 milhões possuíam poço ou nascente e 3 milhões, outras fontes

\footnotetext{
${ }^{1}$ Meta no âmbito dos objetivos do milênio da Organização das Nações Unidas para redução da pobreza, reversão do quadro de deterioração ambiental, melhoramento da educação e da saúde, entre outros.
} 
de abastecimento de água. Daqueles que eram atendidos por outras fontes, como reservatório abastecido por carro-pipa ou água de chuva, $67 \%$ estavam localizados na região Nordeste (IBGE, 2001). Quanto ao esgotamento sanitário, dos quase 45 milhões de domicílios, 41,1 milhões tinham banheiro ou sanitário, enquanto 3,7 milhões eram desprovidos desta infra-estrutura. Destes domicílios, $72,5 \%$ estavam localizados na região Nordeste (Ib. Idib.).

Neste contexto, $42,1 \%$ das crianças e adolescentes do semi-árido brasileiro, localizado predominantemente na região Nordeste, não dispõem de rede de distribuição, poço ou nascente na propriedade (GOMES FILHO, 2003). Referido percentual é semelhante ao encontrado para a falta de acesso à rede coletora, fossa séptica ou negra. Tais deficiências de infra-estrutura estão relacionadas a algumas doenças de veiculação hídrica, como a diarréia, responsável por $40 \%$ das internações hospitalares no semi-árido do Nordeste em 2001 (Id. Ibid.). Dos quase 3,5 milhões de internações hospitalares do país, vinculadas com a falta de saneamento básico no período de 1995 a 1999, 44,64 \% estavam localizadas na região Nordeste (ABICALIL, 2002).

Diversos são os fatores responsáveis pelo déficit dos serviços de água e esgoto no país. Destes, podem ser mencionadas a fragmentação de políticas públicas e a carência de instrumentos de regulamentação e de regulação (NASCIMENTO e HELLER, 2005). De fato, desde o final dos anos 1980, com a extinção do Plano Nacional de Saneamento, o país não dispõe de política setorial ${ }^{2}$ consistente de água $\mathrm{e}$ esgoto. $\mathrm{O}$ principal impasse para o estabelecimento desta política é a ausência de definição na Constituição Federal da titularidade dos serviços nos sistemas integrados e nas regiões metropolitanas, cuja decisão encontra-se sob análise do Supremo Tribunal Federal ${ }^{3}$. Desde então, inúmeros projetos de lei de política nacional, entre eles os de $n^{\text {os }} 199 / 91,266 / 96,4.147 / 01$, e 5.296/05, foram debatidos no âmbito do Congresso Nacional e pelos atores do setor. Como resultado, poucos

\footnotetext{
${ }^{2}$ Compreendida como o conjunto de leis, mecanismos de investimentos, políticas regulatórias, entre outros.

${ }^{3} \mathrm{ADIN} \mathrm{n}^{\circ} 1.842$, referente à ação impetrada pelo Partido Democrático Trabalhista contra o Governo e a Assembléia Legislativa do Estado do Rio de Janeiro; e a $\operatorname{ADIN~}^{\circ} 2.077$, argüída pelo Partido dos Trabalhadores contra a Assembléia Legislativa do Estado da Bahia.
} 
são os estados e municípios que possuem políticas setoriais, o que se constitui em mais um entrave para a expansão da infra-estrutura.

Somente no início de 2007 foi promulgada a Lei $\mathrm{n}^{0} 11.445 / 2007$, que estabelece as diretrizes nacionais para o saneamento básico. Entre os princípios da lei destaca-se a universalização, conceituada como a "ampliação progressiva do acesso de todos os domicílios ocupados ao saneamento básico" (BRASIL, 2007a). Esta lei pretende ser o ponto de inflexão do setor, apontando mecanismos efetivos para a universalização dos serviços. A regulação é um dos principais instrumentos, e deve ser realizada com independência, definida como autonomia administrativa, orçamentária e financeira da entidade reguladora, além de transparência, tecnicidade, celeridade e objetividade das decisões.

O estudo da regulação permite, entre outros, conhecer seus limites e potencialidades, para se ter clareza de que forma esta atividade pode contribuir efetivamente para a universalização da prestação dos serviços de água e esgoto. Assim, não se espera que a regulação venha remover todos os obstáculos à universalização, mas é preciso considerá-la no conjunto de soluções como parcela significativa para consecução deste objetivo.

$\mathrm{Na}$ busca da universalização, a regulação pode exercer vários papéis. Um deles é fazer cumprir, por meio das políticas regulatórias, as macrodefinições estabelecidas nas políticas públicas setoriais decididas no âmbito dos poderes executivo e legislativo. Outro papel seria desenvolver mecanismos que incentivem a obtenção de eficiência das empresas prestadoras de serviço, pois, desse modo, mais recursos poderão ser canalizados para a expansão da infra-estrutura. Além disso, a regulação proporciona ambiente mais estável para realização de investimentos públicos e privados no setor.

Entretanto, o ganho de eficiência obtido com a regulação da prestação dos serviços é uma condição fundamental, mas não suficiente para que se tenha maior eficácia social. Para tanto, é necessário que os ganhos de eficiência das empresas reguladas sejam apropriados pela sociedade.

Inicialmente, a regulação da prestação de serviços públicos por meio de comissões foi discutida no país no âmbito das propostas para elaboração do Código das Águas nos anos 1930. Com o advento do Estado Novo e as subseqüentes 
políticas desenvolvimentistas dos anos 1950 a 1970, a provisão da infra-estrutura ocorreu de forma direta pelo Estado, limitando a regulação, em geral, à expedição de normas e regulamentos pelo poder executivo, apesar dos avanços regulatórios no setor de energia elétrica. Esse modelo de regulação, no qual a propriedade estatal era a principal característica, vigorou no país até o final dos anos 1980 .

Apenas em meados dos anos 1990, com os processos de privatização das áreas de energia e de telefonia, é que a regulação, modelada no formato de agências reguladoras, foi efetivamente implantada no país. Naqueles setores onde permaneceu a prestação estatal, como o saneamento básico, a regulação alcança somente $13 \%$ das concessões do país ${ }^{4}$ (GALVÃO JUNIOR e PAGANINI, 2006).

A implantação da regulação no setor de água e esgoto apresenta enormes desafios, ainda mais se considerar seu estabelecimento em regiões carentes como o Nordeste brasileiro. Não obstante o déficit de infra-estrutura, há falta de capacidade político-administrativa dos entes federados, sobretudo os municípios, para prover regulação nos termos da Lei ${ }^{0}$ 11.445/2007.

Outro aspecto relevante na discussão sobre regulação e universalização dos serviços de água e esgoto é a escassez de pesquisas na área institucional, fundamental como contribuição para a solução dos problemas do déficit de atendimento. A lacuna no campo do conhecimento das questões institucionais é evidente, até porque a regulação esteve ausente da pauta da agenda setorial nas três últimas décadas. Efetivamente, no campo da pesquisa do saneamento básico, somente as questões tecnológicas têm ocupado espaço com muitos avanços ocorridos particularmente nas áreas de tratamento de água e de esgotos. Outra evidência da falta de prioridade da discussão político-institucional do setor é a ausência de disciplinas ligadas às questões institucionais da grade curricular dos cursos de graduação e pós-graduação das ciências afins ao saneamento básico.

$\mathrm{O}$ ambiente institucional do setor aponta para a necessidade de estudos e pesquisas que estabeleçam diretrizes para elaboração de políticas públicas setoriais e regulatórias, identifiquem formas de arranjos federativos de regulação, discutam desenhos de agências reguladoras adaptados às realidades regionais e, em especial,

\footnotetext{
${ }^{4}$ Estimativa para o ano de 2006.
} 
indiquem caminhos para a universalização dos serviços. Considerando a relevância destes temas, HELLER et al. (2007) afirmam que a comunidade acadêmica tem estado ausente desta discussão.

Além disso, a interdisciplinaridade da temática regulatória abrange os campos da saúde pública, engenharia, direito, economia, ciências sociais, entre outros. Ao discutir a universalização dos serviços de água e esgoto, está-se diante de questões associadas à saúde pública e à engenharia sanitária, que buscam de forma integrada soluções tecnológicas e institucionais que resultem em eficácia social, traduzida na sustentabilidade dos sistemas e conseqüente redução de índices de morbi-mortalidade causados por doenças de veiculação hídrica. Ao mesmo tempo, a regulação do saneamento básico envolve o estudo da economia, relacionada à análise da viabilidade econômico-financeira dos sistemas e dos investimentos necessários para universalizar a infra-estrutura, assim como a disciplina do direito, a qual, por meio de políticas públicas e instrumentos normativos, equaciona arranjos legais que dêem validade às ações propostas. Tem-se ainda a inclusão da disciplina das ciências sociais, pois a regulação não prescinde da participação social para sua efetividade e legitimação no controle dos serviços públicos de natureza essencial, afora o estudo do comportamento dos atores setoriais e sociais, objeto também de análise das ciências econômicas.

Diante do contexto da provisão dos serviços de água e esgoto na região Nordeste e suas repercussões, marcado pelo déficit de atendimento e elevados indices de doenças associadas à falta de saneamento básico, e cuja operação em mais de $\mathbf{8 0} \%$ dos municípios encontra-se sob responsabilidade das companhias estaduais, a maioria ineficientes, é de se esperar que a regulação assuma papel fundamental na melhoria da prestação dos serviços na região. Entretanto, para o adequado desempenho desta atividade, exige-se uma regulação pró-ativa, independente e autônoma, técnica e capaz também de contribuir, por meio do poder de recomendação, com sugestões e soluções para a elaboração de políticas públicas setoriais.

Portanto, o desafio desta tese, acerca da regulação e da universalização dos serviços de água e esgoto na região Nordeste, decorre da possibilidade de indicar subsídios para a formulação de modelos regulatórios, que apontem a regulação como 
instrumento efetivo para eficiência, mudança cultural no setor, melhoria da prestação dos serviços e, notadamente, para sua universalização.

\subsection{OBJETIVOS}

\subsubsection{Geral}

Analisar as experiências regulatórias para a prestação dos serviços de água e esgoto no Nordeste brasileiro e oferecer subsídios para elaboração e aperfeiçoamento de modelos regulatórios pró-universalização.

\subsubsection{Específicos}

- Discutir o papel da regulação como instrumento de incentivo à universalização dos serviços de água e esgoto.

- Avaliar as características das experiências de regulação existentes no Nordeste brasileiro.

- Propor arranjos institucionais que envolvam estados e municípios para regulação da prestação dos serviços de água e esgoto na região Nordeste do Brasil.

- Fornecer subsídios para estruturação e fortalecimento institucional de agências reguladoras para o Nordeste brasileiro. 


\section{METODOLOGIA}

De acordo com classificação proposta por GIL (2002), a presente pesquisa quanto aos seus objetivos gerais é do tipo exploratória. Segundo este autor, estas pesquisas têm como escopo principal o aprimoramento de idéias, com um planejamento bastante flexível que possibilita a avaliação dos mais variados aspectos do objeto do estudo.

Os procedimentos técnicos utilizados no desenvolvimento desta tese foram as pesquisas bibliográfica e documental, assim como a entrevista.

\subsection{OBJETO DA PESQUISA}

$\mathrm{Na}$ investigação desenvolvida, o objeto da pesquisa foi a regulação da prestação dos serviços de água e esgoto na região Nordeste do Brasil e as agências reguladoras de âmbito estadual, que possuem competência para regular o saneamento básico na região.

O estudo da regulação no Nordeste brasileiro foi definido por ser esta região carente de infra-estrutura, ter a prestação dos serviços operada majoritariamente pelas Companhias Estaduais de Saneamento Básico e por compreender que a regulação do setor contribuirá de forma relevante para a ampliação dos índices de atendimento de água e esgoto na região e, conseqüentemente, para a universalização dos serviços. Além disso, já há no Nordeste algumas experiências regulatórias em andamento, as quais poderão contribuir para a expansão desta atividade no restante da região assim como em todo o país.

No âmbito das agências estaduais de saneamento básico foram estudadas as seguintes entidades:

- Agência Reguladora do Estado da Paraíba, em fase de implantação da regulação; 
- Agência Reguladora de Serviços Públicos do Estado de Alagoas, em fase de implantação da regulação ;

- Agência Reguladora de Serviços Públicos Delegados do Estado do Ceará, com regulação setorial iniciada em 2001;

- Agência de Regulação dos Serviços Públicos Delegados do Estado de Pernambuco, com regulação setorial iniciada em 2002.

No Estado do Rio Grande do Norte, a Agência Reguladora de Serviços Públicos não tem competência legal para atuar no saneamento básico. Mas a Agência Reguladora de Serviços de Saneamento Básico do Município de Natal/RN, responsável pela regulação da prestação dos serviços na capital do Estado, atua de forma indireta ${ }^{6}$ na regulação de todo o Estado. Em virtude desta característica, referida agência foi incluida no objeto do estudo.

Quanto aos Estados de Sergipe, Maranhão e Piauí, estes não dispõem de entes reguladores constituídos. Já na Bahia, a Agência de Regulação de Serviços Públicos de Energia, Transportes e Comunicações não possui prerrogativas legais para regular o saneamento básico.

Mesmo diante da ausência de definição do Supremo Tribunal Federal sobre a titularidade dos serviços de água e esgoto, optou-se por pesquisar os Estados, visto que, ante a fragilidade político-institucional da maioria dos municípios da região Nordeste, adquire importância a participação efetiva dos Estados na regulação da prestação dos serviços, por meio de suas agências reguladoras. Ademais, diversos autores apontam dificuldades para viabilização da regulação no âmbito municipal (ARAÚJO, 1999; CONFORTO, 2000; FARIA e FARIA, 2004; GALVÃO JUNIOR et al., 2008; JOURAVLEV, 2001b; MENDES et al., 2006; SEROA DA MOTTA, 2004; SILVA, 2004; TUPPER e RESENDE, 2004; TUROLLA, 2002; VARGAS, 2005).

\footnotetext{
${ }^{5}$ A ARPB e a ARSAL são agências multissetoriais, que já regulam a prestação dos serviços de energia elétrica. Entretanto, apesar de terem competência legal para regular a prestação dos serviços de saneamento básico, a atuação efetiva neste setor ainda não foi iniciada.

${ }^{6}$ As tarifas de água e esgoto definidas para o município de Natal pela ARSBAN desde 2003 são aplicadas em todo o Estado. Isto decorre da existência de tabela única de preços dos serviços de água e de esgoto para todos os municípios do Estado do Rio Grande do Norte operados pela Companhia de Águas e Esgotos do Rio Grande do Norte.
} 
Ainda na região Nordeste, as Companhias Estaduais de Saneamento Básico operam 79,7\% do total dos municípios (MCIDADES, 2006). Isto reforça 0 entendimento de que os Estados são fundamentais no alcance das metas de universalização da região, não obstante reconhecer a importância da participação dos municípios neste processo.

Não se considerou, neste contexto, a análise da regulação por consórcios de municípios, pois, apesar de haver previsão legal, sua execução é complexa em virtude de não haver experiência concreta de regulação por consórcio do saneamento básico no país.

O estudo compreende o período de 1990 a 2007. Considera-se este período oportuno, pois o final da década de 1980 marca o encerramento da última política nacional de saneamento ${ }^{7}$, enquanto no ano de 2007 é promulgada a Lei $\mathrm{n}^{\mathrm{o}}$ 11.445/2007, que estabelece as diretrizes nacionais para o saneamento básico.

Conceitualmente, o saneamento pode ser definido, em sentido amplo, como o conjunto de serviços que compreende: abastecimento de água, esgotamento sanitário, drenagem urbana, coleta e destinação final dos resíduos sólidos, controle de vetores e de reservatórios de doenças transmissíveis, controle da poluição ambiental, entre outros (PHILIPPI JR e SILVEIRA, 2004). Entretanto, o objeto desta pesquisa está limitado à prestação dos serviços de abastecimento de água e de coleta, tratamento $\mathrm{e}$ disposição final de esgotos sanitários, ora denominado de saneamento básico. Esta delimitação metodológica, porém, não descarta a importância dos demais serviços que compõem o saneamento, os quais devem ser objeto de outros estudos, inclusive analisados de forma integrada. Além disso, o emprego da terminologia "setor de água e esgoto" nesta pesquisa, usual nas discussões da área, tem como objetivo facilitar o entendimento das questões aqui analisadas.

\footnotetext{
${ }^{7}$ Um dos marcos que assinalam o encerramento do PLANASA foi a extinção do BNH, em 1986, por meio do Decreto-Lei ${ }^{\circ} 2.291$, de 21 de novembro de 1986.
} 


\subsection{PESQUISA BIBLIOGRÁFICA E DOCUMENTAL}

A busca por dados bibliográficos justifica-se pelo fato de possibilitar conhecimento pautado na revisão de dados científicos publicados e disponíveis. A principal vantagem da pesquisa bibliográfica é a possibilidade de o pesquisador cobrir uma maior quantidade de fenômenos representativos sem a necessidade de realizar pesquisa direta (GIL, 2002).

Inicialmente foi pesquisado o estado da arte relacionado aos seguintes temas: universalização dos serviços de água e esgoto, teoria da regulação, desenho regulatório e regulação setorial. Posteriormente, estes grandes temas foram detalhados em nível do objeto do estudo, abrangendo os seguintes tópicos: padrões de atendimento, mecanismos de políticas públicas para universalização; evolução da teoria da regulação; propriedade estatal ${ }^{8}$; marcos regulatórios; desenho regulatório; aspectos legais e institucionais da prestação dos serviços de água e esgoto; e controle social da prestação dos serviços.

Fontes relevantes de informações foram as pesquisas do Instituto Brasileiro de Geografia e Estatística, a saber: Pesquisa Nacional de Saneamento Básico, Censo Demográfico, Pesquisa Nacional por Amostra de Domicílios e demais estudos produzidos por este instituto.

Segundo LAKATOS e MARCONI (1985), a pesquisa documental tem como finalidade a procura dos materiais escritos que possam servir como fonte de informações para a pesquisa científica e que ainda não foram tratados cientificamente. Entre as vantagens da pesquisa documental destacam-se a riqueza e a estabilidade dos dados pesquisados e o custo quando comparado com outros tipos de pesquisa (GIL, 2002). Foram pesquisados os seguintes tipos de documentos e dados nos órgãos governamentais públicos das esferas federal e estadual: leis estaduais das políticas de água e esgoto e da criação das entidades reguladoras; critérios para atendimento às camadas mais pobres da população; contratos de

\footnotetext{
${ }^{8}$ Definida como a provisão direta de bens e serviços pelo Estado.
} 
concessão e leis autorizativas das concessões; marcos regulatórios de setores da infra-estrutura; e normas da prestação dos serviços de água e esgoto.

No âmbito federal foram consultados estudos do Instituto de Pesquisas e Economia Aplicada do Governo Federal, do Banco Nacional de Desenvolvimento Econômico e Social, da Fundação Nacional de Saúde e do Programa de Modernização do Setor de Saneamento do Ministério das Cidades. Também foram examinados documentos de instituições internacionais como o Banco Internacional para Reconstrução e Desenvolvimento e a Organização das Nações Unidas por meio de suas instituições: Fundo das Nações Unidas para a Infância, Organização Mundial da Saúde, Organização Pan-Americana da Saúde e Comissão Econômica para a América Latina e o Caribe.

Outras fontes pesquisadas foram os documentos elaborados por entidades representativas de segmentos da prestação dos serviços como a Associação da Empresas de Saneamento Básico Estaduais, Associação Nacional dos Serviços Municipais de Saneamento, Associação Brasileira das Indústrias de Base, Associação Brasileira das Concessionárias de Serviços Públicos de Água e Esgoto e Associação Brasileira de Engenharia Sanitária e Ambiental.

A partir da coleta destas informações, os dados foram analisados, inferidos e discutidos.

\subsection{ENTREVISTAS}

De acordo com LAKATOS e MARCONI (1985), a entrevista é um encontro entre duas pessoas, a fim de que uma delas obtenha informações a respeito de determinado assunto, mediante conversa de natureza profissional. Este procedimento técnico permite ao pesquisador obter dados que poderia conseguir de outras fontes como estatísticas e censos e colher considerações relacionadas diretamente ao entrevistado como atitudes, valores e opiniões (MINAYO, 2004). A entrevista pode ser estruturada, por meio de questionários aplicados pelo pesquisador ou indiretamente mediante roteiros fechados, e semi-estruturada ou não-estruturada, 
onde as questões do roteiro são elaboradas de forma mais abrangente possível, a partir das hipóteses ou pressupostos do pesquisador (Ib. Idib.).

$\mathrm{O}$ instrumento de coleta de dados utilizado na entrevista foi um questionário aberto com base em parâmetros obtidos da literatura, documentos e experiência do autor, com o objetivo de colher opiniões, contribuições e críticas junto aos reguladores dos serviços de água e esgoto para elaboração dos subsídios dos modelos regulatórios estaduais da região Nordeste. Tal documento consta do Anexo 1, onde é apresentado o roteiro das perguntas da entrevista. Esta opção metodológica teve como finalidade adicionar à discussão as percepções dos reguladores do setor, o que a torna relevante em virtude da escassa bibliografia e estudos científicos acerca da temática.

Os entrevistados foram os presidentes, conselheiros diretores ou diretores das agências reguladoras. Este pré-requisito justifica-se, pois foi preciso colher opiniões de gestores representativos e credenciados do pensamento das agências reguladoras. Além disso, as entrevistas pessoais foram posteriormente complementadas com perguntas por e-mail para estes dirigentes.

As entrevistas foram realizadas no segundo semestre de 2007, após a conclusão da discussão do arcabouço teórico-conceitual da pesquisa. Desta forma, a construção das perguntas argüídas aos reguladores possibilitou aprofundar alguns temas não contemplados na discussão da literatura.

Os dados qualitativos obtidos por meio das entrevistas foram analisados e agregados às informações coletadas na pesquisa bibliográfica e documental, fornecendo assim elementos para as discussões e conclusões acerca dos subsídios dos modelos regulatórios de água e esgoto para os Estados da região Nordeste. 


\subsection{REGIÃO NORDESTE}

\subsubsection{Características Gerais}

Composta por nove Estados: Bahia, Sergipe, Alagoas, Pernambuco, Paraiba, Rio Grande do Norte, Ceará, Piauí e Maranhão, e 1.793 municípios, a região Nordeste possui uma área de $1.561 .177,8 \mathrm{~km}^{2}$. Esta área equivale a $18,26 \%$ do território nacional, na qual os planaltos são a forma predominante de relevo (MRE, 2007).

De acordo com a contagem populacional de 2007 do IBGE, o Nordeste possui 51.535 .782 habitantes, equivalente a $28 \%$ da população brasileira (IBGE, 2007a).

Em relação ao Produto Interno Bruto, ano 2003, segundo apontam estatísticas do IBGE, o Nordeste participou com $13,8 \%$ do PIB, menor que as regiões Sudeste e Sul, com 55,2 e 18,6\%, respectivamente (IBGE, 2003a). Apenas os Estados da Bahia, Pernambuco e Ceará concentram dois terços da produção econômica da região (Id. Ibid.). Um dos aspectos decisivos para o baixo desempenho econômico da região é a vulnerabilidade econômica às variações climáticas, principalmente em função da ocorrência de longos períodos de estiagem (GAESE, 2003).

Conforme dados da Tabela 1, dos 1.793 municípios, 68,3\% possuem até 20 mil habitantes, totalizando cerca de um quarto da população da região. Da mesma forma, nos 11 municípios com mais de 500 mil habitantes, vive um quarto dos moradores, o que demonstra elevado nível de concentração populacional nas grandes cidades, entre as quais se encontram as nove capitais dos Estados. 
Tabela 1 - Características demográficas e fiscais dos municípios nordestinos.

\begin{tabular}{lccccccc}
\hline \multirow{2}{*}{$\begin{array}{c}\text { Faixa } \\
\text { Populacional }\end{array}$} & \multicolumn{2}{c}{ Municípios } & \multicolumn{2}{c}{ População } & \multicolumn{2}{c}{ Valor acumulado (x 1.000 RS), ano 2005 } \\
\cline { 2 - 7 } & Quant. & $\%$ & Total & $\%$ & $\begin{array}{c}\text { Receita } \\
\text { Arrecadada }^{(\mathbf{1})}\end{array}$ & Despesa Realizada $^{(2)}$ \\
\hline $\begin{array}{l}\text { Até 20.000 hab. } \\
\text { De 20.001 a }\end{array}$ & 1.224 & 68,3 & 12.186 .922 & 23,6 & $8593.707,56$ & $9.007 .702,76$ \\
100.000 hab. & 518 & 28,9 & 19.254 .908 & 37,4 & $10.926 .846,18$ & $12.898 .103,56$ \\
$\begin{array}{l}\text { De 100.000 a } \\
\text { 500.000 hab. }\end{array}$ & 40 & 2,2 & 7.395 .234 & 14,4 & $4.542 .055,95$ & $4.566 .221,84$ \\
$\begin{array}{l}\text { Acima } \\
500.000 \text { hab. }\end{array}$ & 11 & 0,6 & 12.698 .718 & 24,6 & $\mathbf{8 . 7 6 2 . 0 5 0 , 2 3}$ & $\mathbf{8 . 2 9 0 . 4 7 5 , 4 4}$ \\
\hline \multicolumn{1}{c}{ Total } & $\mathbf{1 . 7 9 3}$ & $\mathbf{1 0 0}$ & $\mathbf{5 1 . 5 3 5 . 7 8 2}$ & $\mathbf{1 0 0}$ & $\mathbf{3 2 . 8 2 4 . 6 5 9 , 9 2}$ & $\mathbf{3 4 . 7 6 2 . 5 0 3 , 6 1}$ \\
\hline
\end{tabular}

Fonte dos dados: IBGE, 2007a; IBGE, 2007b.

Notas:

(1) A receita arrecadada do município inclui o total efetivamente proveniente da arrecadação do município, o total das transferências realizadas pela União ou pelo Estado e as receitas de capital.

(2) A despesa realizada pelo município refere-se ao total do orçamento gasto pelo município, de acordo com todas as funções existentes.

Ainda de acordo com a Tabela 1, o conjunto dos municípios com população até 500 mil habitantes é deficitário em termos fiscais, onde as receitas arrecadadas são insuficientes para cobrir as despesas realizadas pelas administrações locais. Estes dados indicam a situação de déficit financeiro dominante nos municípios, notadamente os de pequeno porte, e a dependência de recursos e transferências de outros entes federados para se garantir a manutenção destas administrações.

A repercussão desta realidade pode ser vista na dificuldade dos municípios em assumirem diretamente novos encargos administrativos, como a regulação da prestação dos serviços de água e esgoto, agravada pela falta de quadros técnicos qualificados para gestão das máquinas públicas.

\subsubsection{Situação do Saneamento Básico}

Conforme dados apontados pelo Censo 2000 e pela Pesquisa Nacional por Amostragem de Domicílios, ano 2005, a região Nordeste apresenta ainda grave quadro de déficit no acesso aos serviços de saneamento básico, principalmente em relação ao esgotamento e tratamento dos esgotos. Na Figura 1 está exposta a situação da cobertura de redes de água e esgoto, por Estado e por localização, urbano e rural. 
Figura 1 - Cobertura dos serviços de água e esgoto por redes nos estados da região Nordeste.

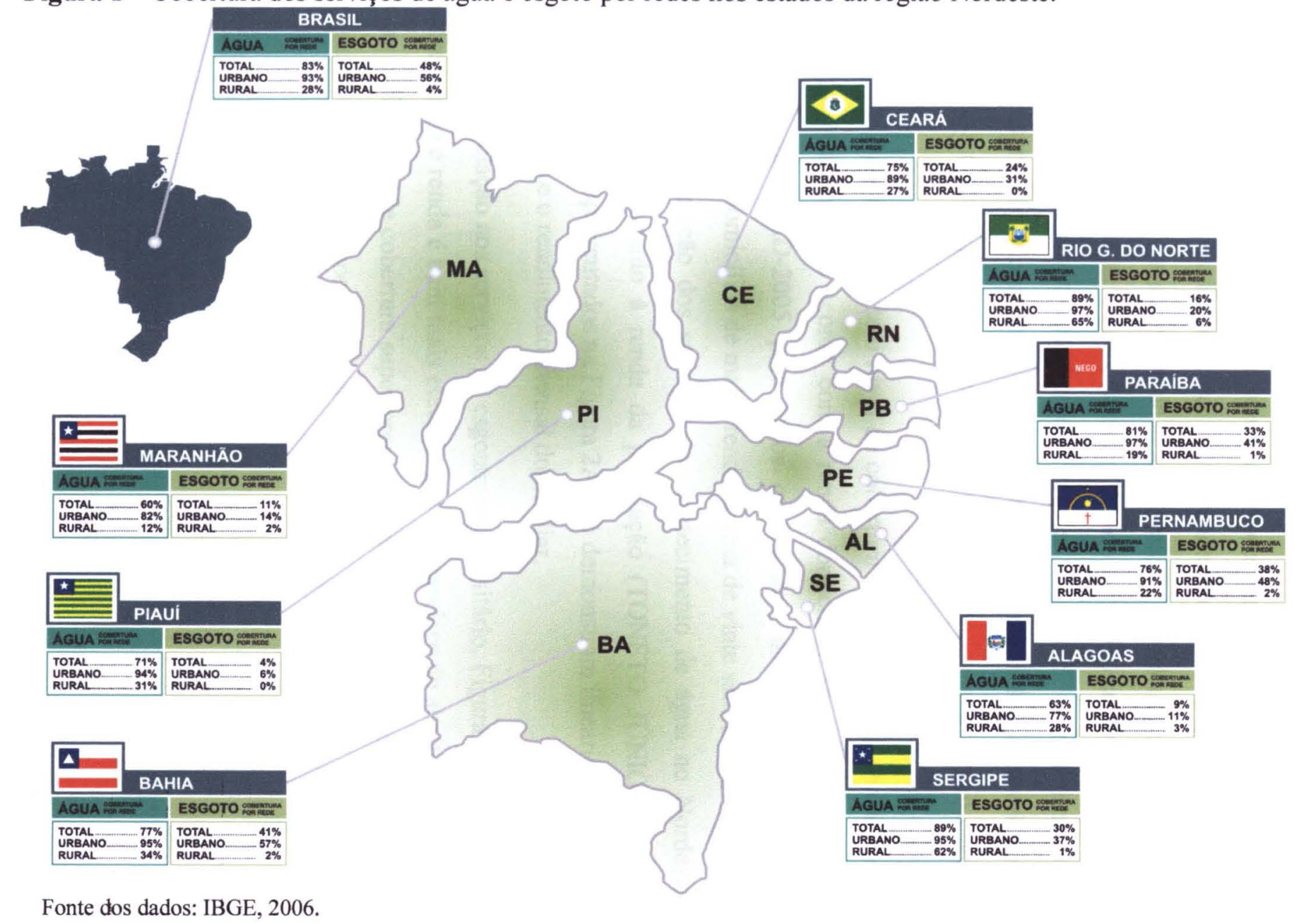

Fonte dos dados: IBGE, 2006. 
Como pode ser observado, as menores coberturas de infra-estrutura sanitária localizam-se nos Estados do Maranhão, com $60 \%$ de cobertura de redes de água, e Piauí, com $4 \%$ de cobertura de redes de esgoto. Já os melhores indicadores são encontrados nos Estados do Rio Grande do Norte e Sergipe, ambos com 89\% de cobertura por redes de água, e no Estado da Bahia, com $41 \%$ de cobertura de redes de esgoto. Quando comparados aos indicadores nacionais, também mostrados na Figura 1, somente os Estados do Rio Grande do Norte e de Sergipe possuem percentual de cobertura por redes de água superiores à média nacional. Já em relação à cobertura por redes de esgoto, nenhum Estado da região supera a média nacional: $48 \%$. Contudo, segundo critérios de pesquisa do IBGE, nem todos os esgotos coletados por redes são tratados, o que agrava ainda mais o déficit setorial. Ademais, parte destas redes é para coleta de águas pluviais, inadequada para o esgotamento sanitário.

Na Figura 2A consta o nível de cobertura dos serviços de abastecimento de água por rede geral de acordo com a renda domiciliar. Segundo demonstram os resultados da PNAD-2005 para todos os Estados, as maiores coberturas são encontradas nos domicílios de maior renda, acima de vinte salários mínimos. Apesar do acesso à prestação dos serviços de abastecimento de água no Nordeste esta diretamente relacionado à renda da população (TONETO JÚNIOR e SAIANI, 2006), os dados apresentados na Figura 2A não demonstram linearidade entre acesso a estes serviços e o rendimento mensal domiciliar.

Em relação aos serviços de esgotamento sanitário, Figura 2B, a desigualdade entre acesso e renda é bem mais elevada que nos serviços de abastecimento de água, com indicadores de cobertura superiores no mínimo duas vezes nos extratos de renda mais elevados do que nos de menor renda. 
Figura 2A - Cobertura de rede de água por classe de rendimento mensal domiciliar nos Estados da região Nordeste.

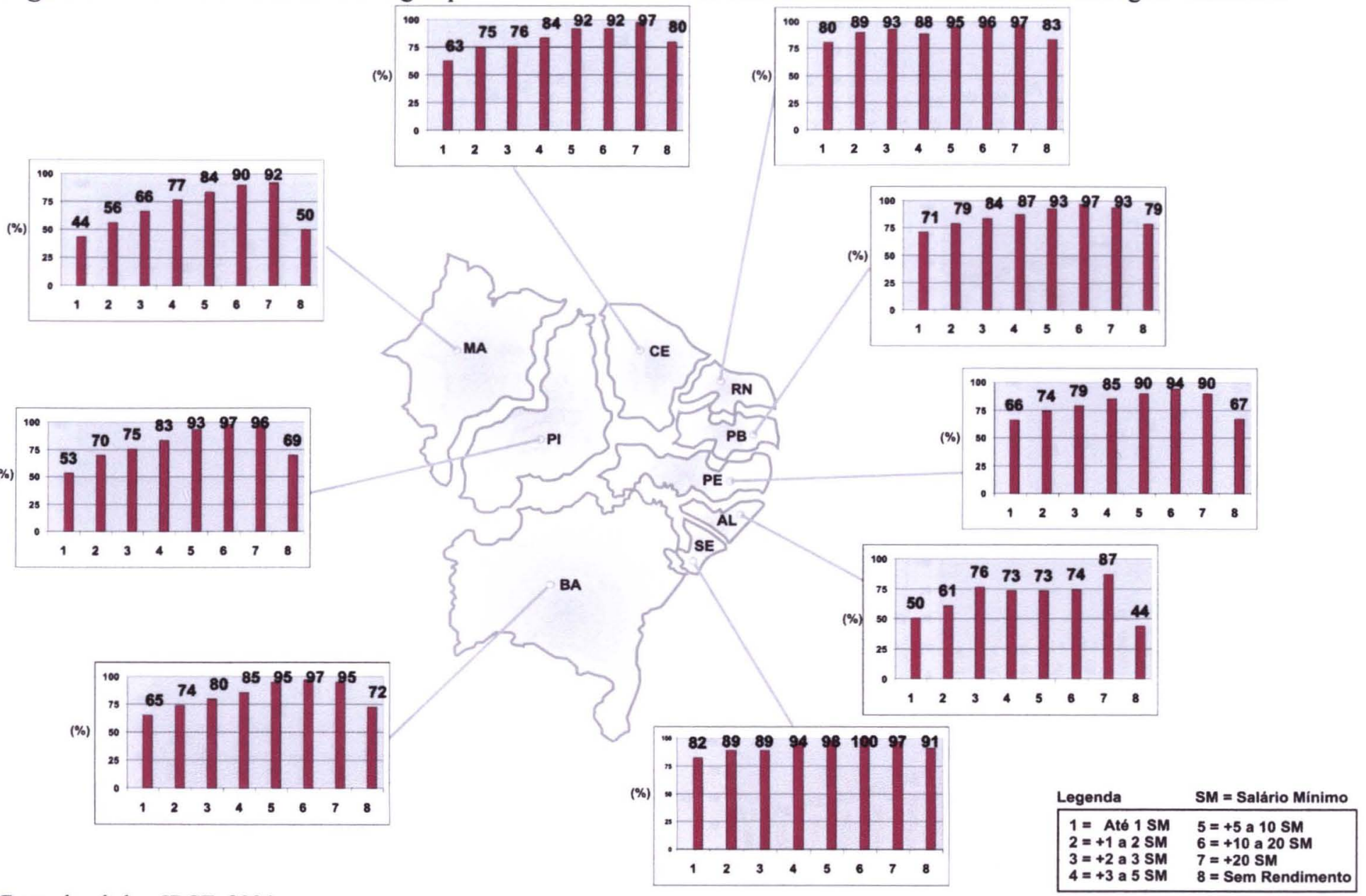

Fonte dos dados: IBGE, 2006. 
Figura 2B - Cobertura de rede de esgoto por classe de rendimento mensal domiciliar nos Estados da região Nordeste.

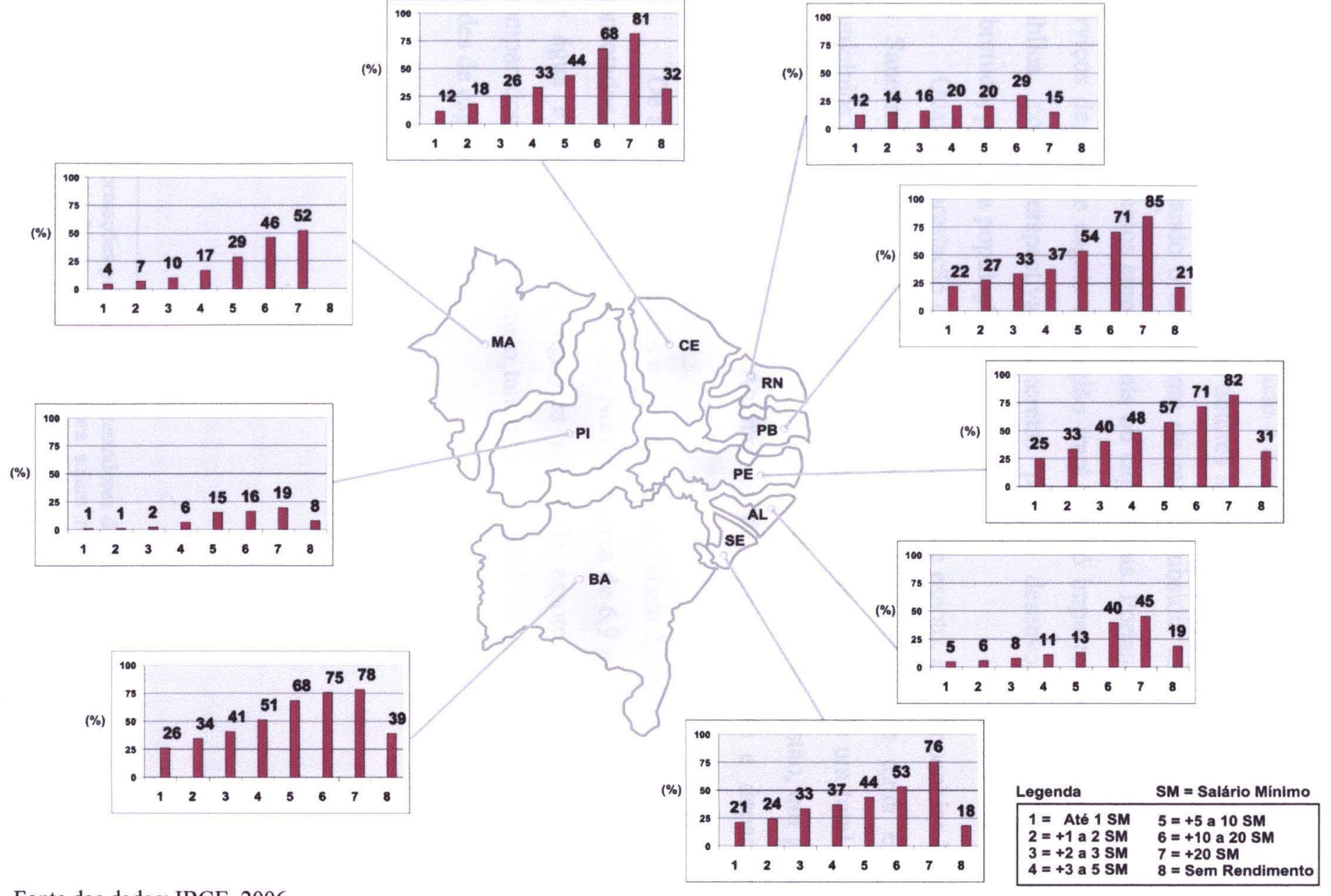

Fonte dos dados: IBGE, 2006. 
Efetivamente, a principal consequiência da ausência de infra-estrutura de saneamento básico na região Nordeste é o elevado índice de internações hospitalares decorrentes de doenças de veiculação hídrica, com repercussão nas taxas de mortalidade infantil (GOMES FILHO, 2003; PENA e ABICALIL, 1999). Além disso, estudo elaborado por SILVA e RESENDE (2005) indica o não acesso aos serviços de água distribuída, a saúde e a educação como causas para a baixa renda dos municípios nordestinos. Estes autores afirmam ainda que o retorno econômico e social é maior quando o orçamento da região subsidia estes serviços públicos ao invés de investimentos empresariais ou capitalistas. Portanto, a universalização dos serviços de água e esgoto na região trará não só impactos positivos para a saúde pública, como perspectivas concretas para o desenvolvimento econômico e, sobretudo, para sua população.

Quanto à prestação dos serviços de água e esgoto, as Companhias Estaduais de Saneamento Básico operam serviços de abastecimento de água em 1.429 municípios e serviços de esgotos sanitários em 166 municípios de um total de 1.793 municípios da região (MCIDADES, 2006). Os demais serviços estão, em geral, sob responsabilidade dos Sistemas Autônomos de Água e Esgoto e departamentos municipais.

De acordo com os dados apresentados na Tabela 2, SNIS $^{9}$ ano de 2005, estão conectados às redes das CESBs do Nordeste cerca de 6,9 milhões de ligações ativas de água e 1,4 milhão de ligações ativas de esgoto. Estes números, quando comparados entre si, mostram o tamanho do déficit no atendimento por ligações e redes de esgotos na região.

\footnotetext{
${ }^{9}$ O SNIS coleta informações primárias dos prestadores de serviço e calcula os indicadores técnicos e econômico-financeiros. Neste cálculo, embora sejam realizados testes de consistência, os dados primários não são auditados. Apesar desta ressalva, o SNIS existe há dez anos e se constitui na referência de dados e informações do setor de saneamento básico no país.
} 
Tabela 2 - Características gerais das companhias estaduais de saneamento básico da região Nordeste.

\begin{tabular}{|c|c|c|c|c|c|c|c|c|c|}
\hline \multirow{2}{*}{ Estado } & \multirow{2}{*}{$\begin{array}{l}\text { Total } \\
\text { Munic. }\end{array}$} & \multirow{2}{*}{ CESB } & \multicolumn{2}{|c|}{$\begin{array}{c}\text { SAA }^{*} \text {-municípios } \\
\text { operados }\end{array}$} & \multicolumn{2}{|c|}{$\begin{array}{c}\text { SES }^{* *}-\text { municípios } \\
\text { operados }\end{array}$} & \multicolumn{3}{|c|}{ Situação da concessão } \\
\hline & & & $\begin{array}{l}\text { Total } \\
\text { Munic. }\end{array}$ & $\begin{array}{c}\text { Lig. } \\
\text { Ativas }\end{array}$ & $\begin{array}{l}\text { Total } \\
\text { Munic. }\end{array}$ & $\begin{array}{c}\text { Lig. } \\
\text { Ativas }^{(2)}\end{array}$ & $\underset{\text { vigor }^{(3)}}{\text { Em }}$ & $\underset{(4)}{\text { Vencida }}$ & $\begin{array}{l}\text { Inexis- } \\
\text { tente }^{(5)}\end{array}$ \\
\hline PI & 222 & AGESPISA & 146 & 448.429 & 4 & 26.226 & 82 & 32 & 32 \\
\hline MA & 216 & CAEMA & 139 & 476.545 & 2 & 102.667 & 88 & 38 & 13 \\
\hline $\mathrm{RN}$ & 166 & CAERN & 147 & 502.009 & 33 & 84.907 & 50 & 48 & 49 \\
\hline $\mathrm{CE}$ & 183 & CAGECE & 150 & 1.057 .938 & 39 & 317.854 & 137 & 12 & 1 \\
\hline PB & 222 & CAGEPA & 175 & 613.850 & 17 & 146.540 & 40 & 114 & 21 \\
\hline $\mathrm{AL}$ & 101 & CASAL & 77 & 299.436 & 2 & 27.772 & 9 & 50 & 18 \\
\hline PE & 184 & COMPESA & 169 & 1.250 .859 & 18 & 236.381 & 166 & 0 & 3 \\
\hline $\mathrm{SE}$ & 75 & DESO & 71 & 349.450 & 5 & 52.223 & 40 & 17 & 14 \\
\hline BA & 416 & EMBASA & 355 & 1.890 .692 & 46 & 417.275 & 335 & 18 & 2 \\
\hline Total & 1.793 & - & 1.429 & 6.889 .208 & 166 & 1.411 .845 & 947 & 329 & 153 \\
\hline
\end{tabular}

Fonte dos dados: MCIDADES, Secretaria Nacional de Saneamento Ambiental, 2006.

Notas:

*SAA - Sistema de Abastecimento de Água; **SES - Sistema de Esgotos Sanitários;

(1) Ligaç̃̃es ativas de água - quantidade de ligações ativas de água à rede pública, providas ou não de aparelho de medição (hidrômetro), que contribuíram para o faturamento no último mês do ano.

${ }^{(2)}$ Ligações ativas de esgoto - quantidade de ligações ativas de esgoto a rede pública que contribuíram para o faturamento no último mês do ano.

${ }^{(3)}$ Municípios atendidos com concessão em vigor - quantidade de municípios em que o prestador de serviços atua por meio de um instrumento de formalização da delegação (contrato ou convênio).

${ }^{(4)}$ Municípios atendidos com concessão vencida - quantidade de municipios em que o prestador de serviços atua por meio de um instrumento de formalização da delegação (contrato ou convênio) com vigência vencida.

${ }^{(5)}$ Municípios atendidos sem concessão - quantidade de municípios em que o prestador de serviços atua onde não exista um instrumento de formalização da delegação (contrato ou convênio).

Em relação à situação contratual destas companhias, a Tabela 2 aponta que $66,3 \%$ das concessões encontram-se em situação regular, com contratos e convênios assinados com os titulares dos serviços. Nas demais concessões, não há contratos ou estes encontram-se vencidos, o que evidencia mais um resultado da frágil institucionalidade do setor.

De forma geral, a operação das CESBs na região Nordeste limita-se às áreas urbanas e adensadas, e a sistemas de abastecimento de água. $\mathrm{O}$ não atendimento a outras áreas é justificado principalmente pela ausência de equilíbrio econômicofinanceiro, pois a população destas áreas não dispõe de capacidade de pagamento de tarifas. Não obstante de o atendimento ser mais amplo nos sistemas de água do que 
nos sistemas de esgoto, os contratos de concessão vigentes ${ }^{10}$ de diversas companhias do Nordeste compreendem a prestação dos serviços tanto de água como de esgoto.

Apesar da ampliação do atendimento do abastecimento de água na região Nordeste, promovido especialmente pelas CESBs ao longo dos últimos trinta anos, uma análise dos dados históricos do Sistema Nacional de Informações em Saneamento revela haver baixa eficiência na maioria das CESBs da região.

Segundo TONETO e SAIANI (2006) destacam, a baixa eficiência operacional e financeira são características gerais do setor, o que limita a execução de investimentos para modernização e expansão da infra-estrutura com recursos próprios. Este contexto pode ser justificado em parte pela ausência de regulação efetiva sobre os prestadores de serviços, ao longo das últimas décadas.

Efetivamente, somente três concessionárias da região são reguladas por agências, CAGECE, COMPESA e CAERN, desde o início dos anos 2000. Estas, entretanto, estão submetidas a marcos legais frágeis em virtude da ausência de diretrizes nacionais para a regulação, o que só ocorreu no ano de 2007.

10 Como exemplo, tem-se que os contratos da CAGECE, AGESPISA e CAERN, assinados anteriormente à Lei dos Consórcios, admitem a concessão plena. 


\section{REVISÃO DA LITERATURA}

\subsection{UNIVERSALIZAÇÃO DOS SERVIÇOS DE ÁGUA E ESGOTO}

O acesso aos serviços de saneamento básico é condição necessária à dignidade da pessoa humana e, particularmente, à sua própria sobrevivência. Portanto, a participação do indivíduo na atividade econômica e social depende de uma vida saudável na qual o acesso a estes serviços é requisito básico, assim como a moradia, a saúde e a educação.

Conforme a Declaração Universal dos Direitos Humanos da Organização das Nações Unidas assegura em seu art. $25, \S 1^{\circ}$,

Toda pessoa tem direito a um padrão de vida capaz de assegurar a si e à sua família saúde e bem-estar, inclusive alimentação, vestuário, habitação, cuidados médicos e os serviços sociais indispensáveis, e direito à segurança em caso de desemprego, doença, invalidez, viuvez, velhice ou outros casos de perda dos meios de subsistência em circunstâncias fora de seu controle.

Este artigo não é taxativo quanto ao reconhecimento do acesso à água como direito universal da pessoa humana, o que resultou em muitas controvérsias na comunidade internacional. Após esse direito ter sido referendado em inúmeros fóruns internacionais ${ }^{11}$ da própria $\mathrm{ONU}$, a consideração formal ocorreu somente no ano de 2002 com a Convenção Internacional sobre Direitos Econômicos, Sociais e Culturais, arts. 11 e 12 (ONU, 2003). Desta forma, os direitos humanos, originalmente tratados como equidade, liberdade, felicidade, vida e propriedade, avançaram conceitualmente no sentido de que todas as pessoas também tenham direito a um ambiente salubre (RIBEIRO, 2004), do qual o acesso à água potável e ao esgotamento e tratamento dos esgotos são partes integrantes.

\footnotetext{
${ }^{11}$ Convenção sobre eliminação de todas as formas de discriminação contra as mulheres, art. 14, §2; Convenção sobre os direitos das crianças, art. $24, \S 2^{\circ}$; Convenção sobre tratamento de prisioneiros de Guerra, arts. 20, 26, 29 e 46; Convenção sobre tratamento de pessoas civis em tempos de guerra; $\S$ 18.47 da Agenda 21; entre outros (ONU, 2003).
} 
No Brasil, o acesso universal aos serviços de água e esgoto está amparado de forma implícita e explícita em várias legislações, inclusive nas áreas afins como recursos hídricos, meio ambiente, saúde pública, defesa do consumidor e desenvolvimento urbano. No Quadro 1 estão relacionados de forma sucinta as disposições na legislação nacional. 
Quadro 1 - Legislação relevante para a universalização dos serviços de água e esgoto

\begin{tabular}{|c|c|}
\hline Legislação & Dispositivos \\
\hline $\begin{array}{l}\text { Constituição } \\
\text { Federal }\end{array}$ & $\begin{array}{l}\text { Art. } 1^{\circ} \text { - A República Federativa do Brasil, formada pela união indissolúvel dos Estados e Municípios } \\
\text { e do Distrito Federal, constitui-se em Estado Democrático de Direito e tem como fundamentos: } \\
\text { II - a cidadania; } \\
\text { III - a dignidade da pessoa humana; } \\
\text { Art. } 3^{\circ} \text { - Constituem objetivos fundamentais da República Federativa do Brasil: } \\
\text { II - garantir o desenvolvimento nacional; } \\
\text { III - erradicar a pobreza e a marginalização e reduzir as desigualdades sociais e regionais; } \\
\text { Art. } 6^{\circ} \text { - São direitos sociais a educação, a saúde, o trabalho, a moradia, o lazer, a segurança, a } \\
\text { previdência social, a proteção à maternidade e à infância, a assistência aos desamparados, na forma } \\
\text { desta Constituiçâo. } \\
\text { Art. } 23 \text { - É competência comum da União, dos Estados, do Distrito Federal e dos Municípios: } \\
\text { VI - proteger o meio ambiente e combater a poluição em qualquer de suas formas; } \\
\text { IX - promover programas de construção de moradias e a melhoria das condições habitacionais e de } \\
\text { saneamento básico; } \\
\text { Art. } 175 \text { - Incumbe ao Poder Público, na forma da lei, diretamente ou sob regime de concessão ou } \\
\text { permissão, sempre através de licitação, a prestação de serviços públicos. } \\
\text { Parágrafo único. A lei disporá sobre: } \\
\text { IV - a obrigação de manter serviço adequado. }\end{array}$ \\
\hline $\begin{array}{l}\text { Lei n' } 6.938 / 81 \text { - } \\
\text { Política Nacional } \\
\text { de Meio } \\
\text { Ambiente }\end{array}$ & $\begin{array}{l}\text { Art } 2^{\circ} \text { - A Política Nacional do Meio Ambiente tem por objetivo a preservação, melhoria e } \\
\text { recuperação da qualidade ambiental propícia à vida, visando assegurar, no País, condições ao } \\
\text { desenvolvimento sócio-econômico, aos interesses da segurança nacional e à proteção da dignidade da } \\
\text { vida humana, atendidos os seguintes princípios: } \\
\text { I - ação governamental na manutenção do equilíbrio ecológico, considerando o meio ambiente como } \\
\text { um património público a ser necessariamente assegurado e protegido, tendo em vista o uso coletivo; }\end{array}$ \\
\hline $\begin{array}{l}\text { Lei } \mathbf{n}^{0} 8.078 / 90- \\
\text { Código de Defesa } \\
\text { do Consumidor }\end{array}$ & $\begin{array}{l}\text { Art. } 6^{\circ} \text { - São direitos básicos do consumidor: } \\
\mathrm{X} \text { - a adequada e eficaz prestação dos serviços públicos em geral. }\end{array}$ \\
\hline $\begin{array}{l}\text { Lei } \mathbf{n}^{0} \mathbf{8 . 0 8 0 / 9 0 -} \\
\text { Estabelece } 0 \\
\text { Sistema Único de } \\
\text { Saúde (SUS) }\end{array}$ & $\begin{array}{l}\text { Art. } 2^{\circ} \text { - A saúde é um direito fundamental do ser humano, devendo o Estado prover as condições } \\
\text { indispensáveis ao seu pleno exercício. } \\
\S 1^{\circ} \text { - O dever do Estado de garantir a saúde consiste na formulação e execução de políticas } \\
\text { econômicas e sociais que visem à redução de riscos de doenças e de outros agravos e no } \\
\text { estabelecimento de condições que assegurem acesso universal e igualitário às ações e aos serviços } \\
\text { para a sua promoção, proteção e recuperação. } \\
\text { Art. } 7^{\circ} \text { - As ações e serviços públicos de saúde e os serviços privados contratados ou conveniados que } \\
\text { integram o Sistema Único de Saúde (SUS), são desenvolvidos de acordo com as diretrizes previstas } \\
\text { no art. } 198 \text { da Constituição Federal, obedecendo ainda aos seguintes princípios: } \\
\text { I - universalidade de acesso aos serviços de saúde em todos os níveis de assistência; } \\
\text { IV - igualdade da assistência à saúde, sem preconceitos ou privilégios de qualquer espécie; }\end{array}$ \\
\hline $\begin{array}{l}\text { Lei } \mathbf{n}^{0} 9.433 / 97 \text { - } \\
\text { Política Nacional } \\
\text { de Recursos } \\
\text { Hídricos }\end{array}$ & $\begin{array}{l}\text { Art. } 2^{\circ} \text { - São objetivos da Política Nacional de Recursos Hídricos: } \\
\text { I - assegurar à atual e à futuras geraçóes a necessária disponibilidade de água, em padrões de } \\
\text { qualidade adequados aos respectivos usos; }\end{array}$ \\
\hline $\begin{array}{c}\text { Lei } \mathbf{n}^{0} \mathbf{1 0 . 2 5 7 / 0 1} \\
\text { - Política } \\
\text { Urbana }\end{array}$ & $\begin{array}{l}\text { Art. } 2^{\circ} \text { - A política urbana tem por objetivo ordenar o pleno desenvolvimento das funções sociais da } \\
\text { cidade e da propriedade urbana, mediante as seguintes diretrizes gerais: } \\
\text { I - garantia do direito a cidades sustentáveis, entendido como o direito à terra urbana, à moradia, ao } \\
\text { saneamento ambiental, à infra-estrutura urbana, ao transporte e aos serviços públicos, ao trabalho e } \\
\text { ao lazer, para as presentes e futuras gerações; }\end{array}$ \\
\hline $\begin{array}{c}\text { Lei n }{ }^{0} 11.445 / 07 \\
\text { - Diretrizes para } \\
\text { o Saneamento } \\
\text { Básico }\end{array}$ & $\begin{array}{l}\text { Art. } 2^{\circ} \text { - Os serviços públicos de saneamento básico serão prestados com base nos seguintes } \\
\text { princípios fundamentais: } \\
\text { I - universalização do acesso; } \\
\text { Art. } 3^{\circ} \text { - Para os efeitos desta Lei, considera-se: } \\
\text { III - universalização: ampliação progressiva do acesso de todos os domicílios ocupados ao } \\
\text { saneamento básico; } \\
\text { Art. } 48 \text { - A União, no estabelecimento de sua política de saneamento básico, observará as seguintes } \\
\text { diretrizes: } \\
\text { I - prioridade para as ações que promovam a eqüidade social e territorial no acesso ao saneamento } \\
\text { básico; } \\
\text { Art. } 49 \text { - São objetivos da Política Federal de Saneamento Básico: } \\
\text { I - contribuir para o desenvolvimento nacional, a redução das desigualdades regionais, a geração de } \\
\text { emprego e de renda e a inclusão social; } \\
\text { II - priorizar planos, programas e projetos que visem à implantação e ampliação dos serviços e ações } \\
\text { de saneamento básico nas áreas ocupadas por populações de baixa renda. }\end{array}$ \\
\hline
\end{tabular}


Conforme explicitado no Quadro 1, a Constituição Federal não reconhece de forma clara a universalidade do acesso aos serviços de água e esgoto como direito social. Entretanto, ao instituir a saúde e a moradia como direitos sociais, entende-se haver contemplado o direito ao acesso a esses serviços, pois, conforme ratificado amplamente na literatura (GLEICK, 1999; HELLER et al., 2003; HUTTON e HALLER, 2004; SOARES et al., 2002; TEIXEIRA e PUNGIRUM, 2005), há correlação direta de causa-efeito entre saneamento e saúde. Esta interpretação está reforçada no art. $1^{\circ}$ da Constituição, que estabelece, entre os fundamentos da República Federativa, a cidadania e a dignidade da pessoa humana. Por outro lado, a Lei $\mathrm{n}^{0} 11.445 / 07$ é taxativa ao definir a universalização como princípio fundamental da prestação dos serviços públicos de saneamento básico. Não obstante se tratar de princípios constitucionais e legais, ARAGÃO (2007) ressalta que, apesar dos efeitos jurídicos que os princípios de uma lei acarretam, o seu caráter abrangente indica que suas consequências dependem das características em cada caso aplicado. Em outras palavras, a garantia legal para a universalização deverá estar assegurada nos marcos de cada concessão, mediante cláusulas e metas de expansão e de atendimento previstas nos contratos de concessão e de programa.

Quanto às legislações das áreas correlatas ao saneamento básico, é implícita a exigência ou recomendação de universalização dos serviços de água e esgoto. No que se refere à lei do SUS, é obrigação deste sistema promover, proteger e recuperar a saúde, traduzida na promoção de ações de saneamento básico e de vigilância sanitária. Ademais, a política nacional de recursos hídricos define como objetivo a garantia da disponibilidade de água para gerações futuras, considerada como a preservação do meio aquoso. Tal fato decorre principalmente de ações de conservação de água e de tratamento de esgotos. Já o Código de Defesa do Consumidor determina que os serviços públicos devem ser prestados de forma adequada, entendida como aquela "que satisfaz as condições de regularidade, continuidade, eficiência, segurança, atualidade, generalidade, cortesia na sua prestação e modicidade das tarifas" (BRASIL, 1995a). A política urbana é enfática em relação à garantia a cidades sustentáveis, que compreende, entre outros, o direito ao saneamento ambiental e à infra-estrutura urbana. Por fim, a política nacional de meio ambiente objetiva a preservação, melhoria e recuperação da qualidade 
ambiental, o que também remete à necessidade de intervenções de saneamento básico.

Os benefícios da universalização dos serviços de água e esgoto são relevantes, mas sua mensuração é complexa, e os métodos tradicionais de contabilização não conseguem avaliar todos os resultados diretos e indiretos, de curto e de longo prazo, e das externalidades nas áreas de saúde pública, meio ambiente, recursos hídricos e desenvolvimento urbano.

Para analisar os impactos da universalização, algumas metodologias foram desenvolvidas, com destaque para os estudos elaborados pela FUNASA e OPAS (BRASIL, 2004a) e pela OMS (HUTTON e HALLER, 2004).

Com o objetivo de avaliar as ações de saneamento desenvolvidas no âmbito do Ministério da Saúde e o respectivo impacto nas populações beneficiadas, a FUNASA e a OPAS estabeleceram metodologia que considera todas as relações intersetoriais do saneamento básico, com fundamento na análise das dimensões antropológica, epidemiológica, tecnológica e econômica (BRASIL, 2004a). Em relação aos benefícios econômicos, o método trabalhado busca apreender os beneficios gerados na saúde com a redução da mortalidade e com o custo do tratamento de doenças evitáveis, além dos não relacionados à saúde, tais como os ganhos de bem-estar, valorização da propriedade imobiliária e tempo poupado no tratamento em face da não ocorrência de enfermidade.

HUTTON e HALLER (2004) desenvolveram pesquisas utilizando os padrões de universalização definidos pela OMS e pelo UNICEF como premissas para dimensionamento tanto intervenções em saneamento básico como dos resultados alcançados. Os benefícios da universalização foram categorizados em econômicos, diretos e indiretos, e os não relacionados à saúde. No cálculo dos benefícios econômicos, foram incluídos aqueles advindos da redução do número de doentes nas áreas da saúde e da produção econômica, assim como as vidas poupadas de adultos e crianças, entre outros. Apesar de estes autores calcularem para o Brasil retorno financeiro entre US\$ 5 e US\$ 15 para cada US\$ 1 investido em abastecimento de água e esgotos sanitários, deve-se ressalvar que estes resultados não guardam necessariamente linearidade entre valores investidos e resultados financeiros em termos de benefícios econômicos diretos e indiretos. 
Apesar da unanimidade quanto às consequuências geradas pela falta de saneamento básico à saúde pública, mediante doenças de veiculação hídrica, BARCELLOS (2005) alerta para os riscos de sobreestimação destes impactos em virtude da interpretação equivocada dos dados dos sistemas de informação em saúde.

Além dos aspectos abordados nestes estudos, a ausência de universalização dos serviços de saneamento básico causa impactos negativos no desenvolvimento econômico, nos recursos hídricos e no meio ambiente, como demonstrado esquematicamente na Figura 3. 
Figura 3 - Impactos negativos da ausência de saneamento básico nos recursos hídricos, meio ambiente e atividades humanas.

- RECURSOS HIDRICOS |> Eutrofização |< Fauna e flora aquaticas

\begin{tabular}{l|l|l} 
E MEIO AMBIENTE & $\begin{array}{l}\text { > Assoreamento } \\
\text { < Navegabilidade }\end{array}$ & > Custo da gestão dos recursos hídricos
\end{tabular}

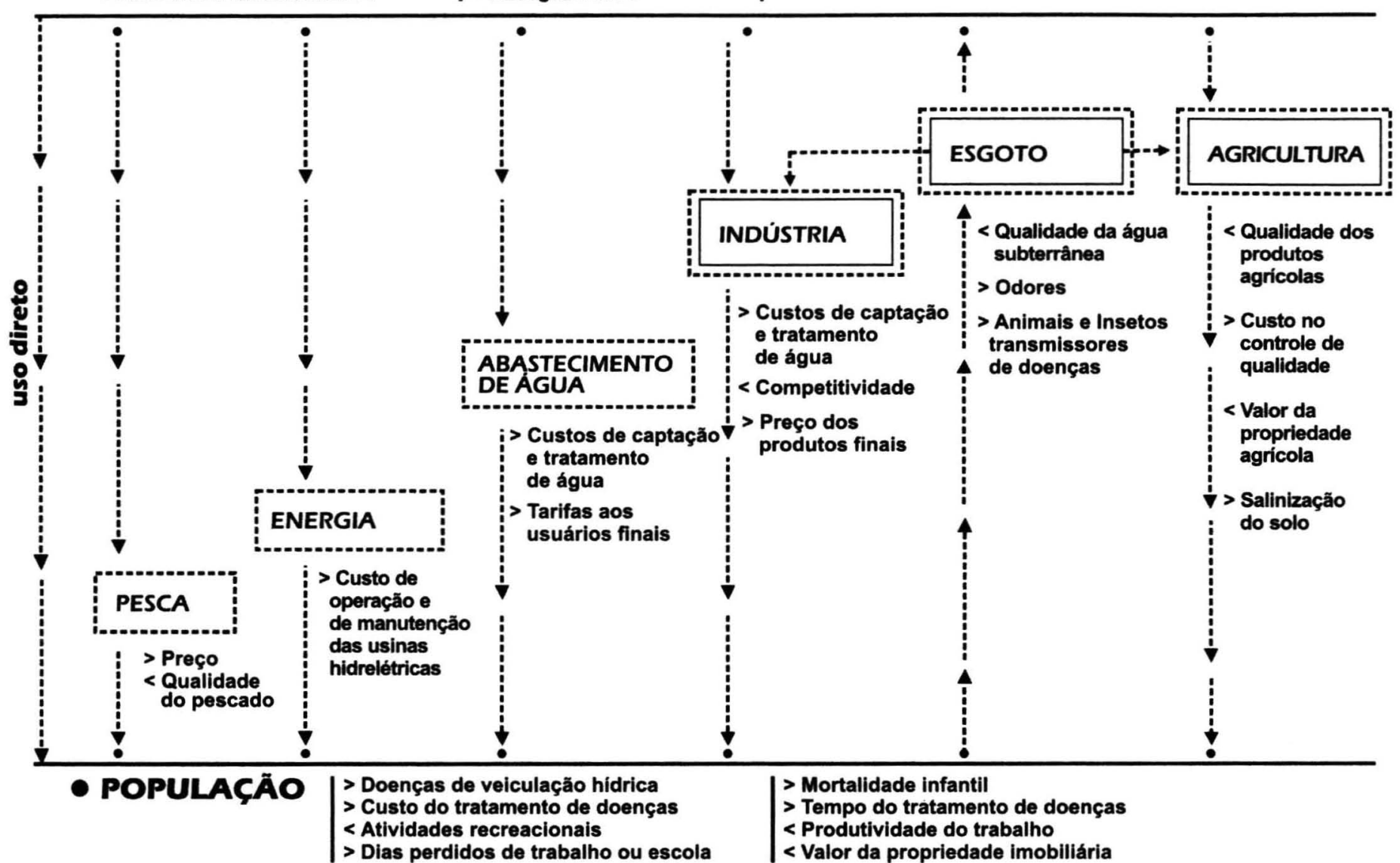

Fonte: Baseado em BRASIL, 2004a; HUTTON e HALLER, 2004; JOURAVLEV, 2004. 
A definição de universalização possui variáveis técnicas, sociais, políticas e econômicas, e segundo BLACKMAN (1995), este conceito tem sido usado e manipulado por diversos grupos para salvaguardar interesses específicos. Assim, ao discutir o acesso universal aos serviços de telecomunicações, GHARAM et al. (1996) questionaram a centralização do debate sob a perspectiva e os anseios da oferta, especificamente os custos e as questões técnicas e regulatórias para se atingir a universalização. Desse modo, pouca atenção tem sido dada para a demanda, usuários efetivos e potenciais, e os impactos sociais e econômicos na população com a universalização destes serviços (Id. Ibid.).

Em relação ao saneamento básico, a perspectiva da demanda é importante, pois, com base nesta, pode-se implantar tecnologia de fácil assimilação pela comunidade beneficiada, sob pena de ser utilizada de forma inadequada ou tornar-se inoperante. Efetivamente, a falta de apropriação das intervenções técnicas de saneamento por parte da população dificulta a ampliação do acesso aos serviços de água e esgoto (HELLER e NASCIMENTO, 2005). No referente aos aspectos técnicos, a universalização não significa o uso exclusivo de tecnologias convencionais e pode, portanto, contemplar alternativas simplificadas e individuais.

PATERSON et al. (2007) relatam que as tecnologias simplificadas não podem ser analisadas de modo preconceituoso ou como se fossem de segunda classe para uso dos mais pobres. A título de exemplo, estes autores discorrem sobre o êxito da aplicação destas tecnologias em comunidades de renda elevada de vários países. Ainda conforme este estudo, para os sistemas de esgotos sanitários, as soluções simplificadas geralmente são as mais viáveis técnica e economicamente para as populações de baixa renda e para áreas de alta densidade urbana. Assim, é necessário distinguir "tecnologias de baixo custo" do "atendimento de baixo padrão" (INFURB, 1995, p. 73), o que exigirá mudanças de comportamento tanto de prestadores de serviço como dos usuários.

Da mesma forma, TRÉMOLET e HUNT (2006) defendem que os padrões de qualidade devam ser adaptados às necessidades locaís no sentido de se obter tarifas sustentáveis. No entanto, é preciso garantir requisitos mínimos de qualidade que não venham a prejudicar a saúde dos usuários, o meio ambiente e os recursos hídricos, bem como identificar os impactos causados pelas soluções simplificadas e 
alternativas, porquanto o mau uso destas tecnologias pode agravar ainda mais as iniqüidades causadas pela falta de acesso aos serviços. Por exemplo, fossas sépticas, quando não operadas adequadamente, comprometem a qualidade do lençol freático e, conseqüentemente, podem contaminar as águas de abastecimento do próprio usuário e das áreas circunvizinhas. Da mesma forma, a não orientação à população quanto aos cuidados de higiene pessoal na utilização destas tecnologias aumenta os riscos de contaminação por via hídrica.

Apesar das discussões, não há solução padrão de tecnologia para a universalização dos serviços. Esta decisão depende da análise de variáveis técnicas, sociais e econômicas envolvidas na implantação e na sustentabilidade dos serviços. Na Figura 4 constam algumas tecnologias para universalização, em caráter não exaustivo, e respectivas etapas de implementação. 
Figura 4 - Algumas tecnologias para universalização dos serviços de água e de esgoto e etapas de implementação.

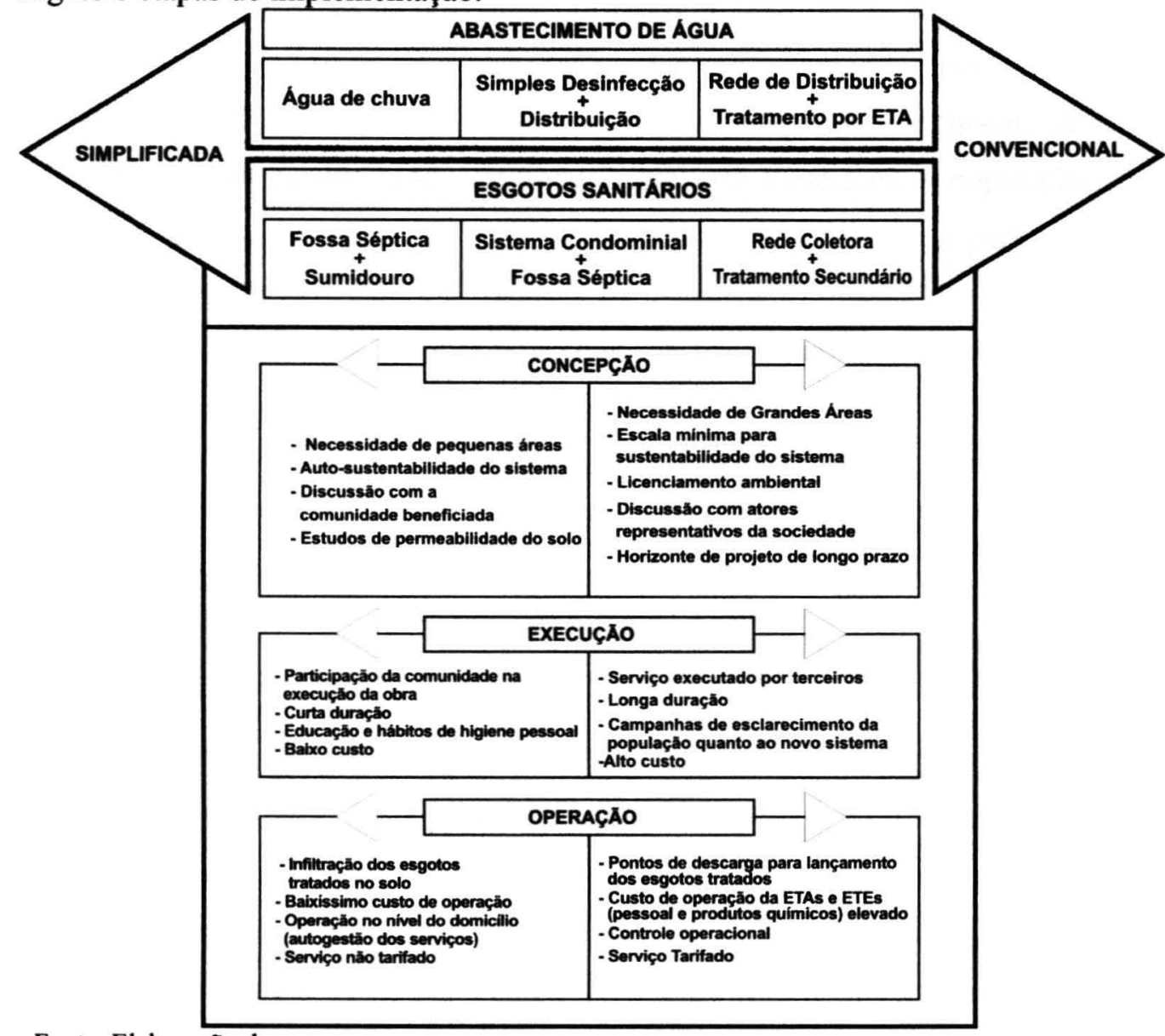

Fonte: Elaboração do autor.

Como mostra a Figura 4, estas variáveis apresentam-se para qualquer tipo de tecnologia envolvida, da simplificada à convencional, e a adoção de tecnologias simplificadas irá requerer mudança no modus operandi dos prestadores de serviço.

Outro aspecto a ser considerado na definição dos critérios de universalização, especificamente em relação ao abastecimento de água, é a qualidade e a continuidade do fornecimento público. Tais condições, quando não satisfatórias, propiciam os mesmos riscos sanitários, por vezes até maiores verificados no caso de usuários conectados a sistemas inadequados. Desta forma, o espalhamento das redes permite erroneamente concluir que os serviços encontram-se universalizados, o que mascara as reais condições de qualidade e de quantidades de acesso a estes serviços (SILVA, 2002). 
Ao aprofundar este tema, SILVA e MACHADO (2001) discutem a interpretação dos índices de cobertura por redes de distribuição de água, utilizados como indicador do acesso universal. Segundo os autores, o indicador de cobertura não reflete as condições de continuidade e de qualidade do abastecimento de água, notadamente nas extremidades das redes onde está localizada a população mais pobre. Além disso, estes indicadores não consideram outros aspectos particulares da prestação dos serviços, como o respeito ao direito dos usuários, as condições de preservação dos recursos hídricos e a conservação e manutenção dos sistemas de água e esgoto, relevantes para a universalização dos serviços (HESPANHOL, 1999).

A consequêencia desta análise é que na formulação das políticas públicas e no dimensionamento dos investimentos, o foco poderia ser considerado, por exemplo, a garantia da continuidade do fornecimento de água.

\subsubsection{Padrões de Atendimento}

No Brasil, a universalização, consoante disposto na Lei $n^{0} 11.445 / 2007$, é conceituada como a "ampliação progressiva do acesso de todos os domicílios ocupados ao saneamento básico" (BRASIL, 2007a). Como se trata de princípio, os padrões e critérios específicos devem ser reportados nos marcos regulatórios dos entes subnacionais.

O principal estudo sobre critérios e custos de universalização no país foi conduzido pelo Ministério das Cidades (BRASIL, 2003), por meio do PMSS. De acordo com este estudo, o serviço é universalizado quando,

$$
\begin{aligned}
& \text { a oferta atende a } 100 \% \text { da demanda, isto é, o serviço estará } \\
& \text { universalizado quando toda a população estiver atendida, } \\
& \text { segundo um determinado padrão de atendimento previamente } \\
& \text { estabelecido, considerando os diferentes usos dos serviços, não } \\
& \text { só nas casas, mas também no comércio, serviços, indústria e } \\
& \text { atividades públicas. }
\end{aligned}
$$

O padrão de atendimento analisado neste trabalho varia conforme o nível de agregação da população, urbano ou rural, e o tipo de sistema, abastecimento de água ou esgotos sanitários, como mencionado no Quadro 2. 
Quadro 2 - Padrões de atendimento para universalização dos serviços de água e esgoto.

\begin{tabular}{|c|c|c|}
\hline \multirow[t]{2}{*}{ População } & \multicolumn{2}{|r|}{ Sistema } \\
\hline & Abastecimento de Água & Esgotos Sanitários \\
\hline Urbana & $\begin{array}{l}\text { - ligações domiciliares } \\
\text { - atendimento contínuo } \\
\text { - padrão de qualidade de acordo } \\
\text { com a legislação }\end{array}$ & $\begin{array}{l}\text { - parte atendida por rede coletora e } \\
\text { tratamento seeundário conforme seguintes } \\
\text { critérios: } \\
\text { Até } 20.000 \text { hab. }-30 \% \text { por rede } \\
\text { De } 20.001 \text { a } 50.000 \text { hab. }-50 \% \text { por rede } \\
\text { De } 50.001 \text { a } 200.000 \text { hab. }-70 \% \text { por rede } \\
\text { Mais de } 200.000 \text { hab. }-90 \% \text { por rede } \\
\text { - parte atendida por fossas sépticas e } \\
\text { dispositivos de infiltração }\end{array}$ \\
\hline Rural* & $\begin{array}{l}\text { - ligações domiciliares } \\
\text { - padrão de qualidade de acordo } \\
\text { com a legislação }\end{array}$ & $\begin{array}{l}\text { - atendimento semelhante às pequenas } \\
\text { localidades urbanas }\end{array}$ \\
\hline
\end{tabular}

Fonte: BRASIL. Ministério das Cidades, 2003.

Nota: * Considerada população aglomerada em pequenas comunidades.

Ainda segundo BRASIL (2003), será necessário cerca de 178 bilhões de reais para a universalização dos serviços de água e esgoto até o ano de 2020 para as cinco regiões geográficas do país, em investimentos de expansão e reposição da infraestrutura, conforme dados apresentados na Tabela 3.

Tabela 3 - Investimentos para universalização dos serviços de água e esgoto no Brasil.

\begin{tabular}{lccc}
\hline \multirow{2}{*}{ Região } & \multicolumn{3}{c}{ Ano - Investimentos acumulados (R milhões) } \\
\cline { 2 - 4 } & 2010 & 2015 & 2020 \\
\hline Norte & 11.275 & 13.835 & 16.307 \\
Nordeste & 27.319 & 32.267 & 37.325 \\
Sudeste & 50.349 & 62.416 & 74.404 \\
Sul & 23.211 & 28.098 & 33.055 \\
Centro-Oeste & 11.470 & 14.507 & 17.314 \\
\hline Brasil & 123.624 & 151.124 & 178.405 \\
\hline
\end{tabular}

Fonte: BRASIL. Ministério das Cidades, 2003.

Apesar da necessidade de aportes significativos para universalizar os serviços, segundo dados oficiais da Secretaria Nacional de Saneamento Ambiental, o governo federal desembolsou, mediante recursos onerosos e não onerosos, $R$ \$ 6,31 bilhões nos anos 2003 a 2006 (BRASIL, 2007b), isto é, uma média anual de R\$1,57 bilhão neste período. Como são necessários $\mathrm{R} \$ 178,4$ bilhões em vinte anos, ou seja, $\mathrm{R} \$ \mathbf{8 , 9}$ bilhões ao ano, os recursos aportados no quadriênio representam somente 
$17,6 \%$ do total. Mesmo adicionando os investimentos oriundos de recursos próprios dos prestadores de serviço, o montante realizado está muito aquém da meta de universalização.

Segundo a AESBE, a continuar com este nível de investimentos, a universalização dos serviços de abastecimento de água ocorrerá no ano de 2034, enquanto os esgotos sanitários seriam universalizados somente em 2054 (AESBE, 2006) ${ }^{12}$. Já o INSTITUTO TRATA BRASIL (2007) apresenta em seu estudo, cenário mais pessimista quanto à universalização do acesso à rede geral de esgoto. De acordo com este estudo, o acesso universal a este serviço se dará apenas no ano de 2122.

Para a OMS e o UNICEF, o padrão de atendimento é definido conforme a tecnologia utilizada (OMS, 2000). Na metodologia adotada por estas organizações, as tecnologias para abastecimento de água e de esgotos sanitários são classificadas em melhoradas ${ }^{13}$ e não melhoradas, de tal forma que as populações atendidas por tecnologias melhoradas são consideradas universalizadas pelos serviços. O Quadro 3 mostra os padrões de atendimento adotados pela OMS e pelo UNICEF.

Quadro 3 - Padrão de universalização dos serviços de água e esgoto da OMS e do UNICEF.

\begin{tabular}{|c|l|l|}
\hline Categoria & \multicolumn{1}{|c|}{ Abastecimento de Água } & \multicolumn{1}{c|}{ Esgotos Sanitários } \\
\hline \multirow{5}{*}{ Melhorado } & $\begin{array}{l}\text { Conexão doméstica } \\
\text { Fonte pública } \\
\text { Poço perfurado } \\
\text { Poço escavado protegido } \\
\text { Captação de água de chuva } \\
\text { Manancial protegido }\end{array}$ & $\begin{array}{l}\text { Conexão a rede pública } \\
\text { Conexão a sistema séptico } \\
\text { Vaso sanitário com descarga } \\
\text { Sanitário de poço simples } \\
\text { Sanitário de poço melhorado - } \\
\text { ventilado }\end{array}$ \\
\hline \multirow{2}{*}{ Não } & $\begin{array}{l}\text { Poço não protegido } \\
\text { Manancial não protegido } \\
\text { Vendedores avulsos de água } \\
\text { Água engarrafada* } \\
\text { Caminhões-pipa }\end{array}$ & $\begin{array}{l}\text { Sanitário de cuba (as excretas } \\
\text { são eliminadas manualmente) } \\
\text { Sanitário público } \\
\text { Sanitário aberto }\end{array}$ \\
\hline
\end{tabular}

Fonte: OMS, 2000.

Nota: * Considerada em função da quantidade e não da qualidade da água.

\footnotetext{
${ }^{12}$ No referido estudo, a universalização dos serviços de água e esgoto é apresentada de forma genérica, não sendo explicitados padrões de atendimento para o alcance desta meta.

${ }^{13} \mathrm{O}$ termo "melhorado" (improved em inglês) substituiu as terminologias "segura" (safe em inglês) para abastecimento de água e "adequado" (adequate em inglês), antes utilizadas pela ONU como padrões, visto que as pesquisas realizadas no âmbito dos domicílios não conseguiam comprovar se as tecnologias eram seguras e/ou adequadas.
} 
Caso estas tecnologias não sejam acompanhadas de padrões de qualidade e de continuidade, o conceito de "melhorado" definido pela OMS e pelo UNICEF pode resultar em avaliações irreais quanto ao atendimento dos serviços. Desse modo, os critérios definidos pelo estudo do Ministério das Cidades, associados a padrões de qualidade, estão mais focados na realidade nacional.

\subsubsection{Mecanismos de Políticas Públicas de Universalização}

Dispor de serviços de água e esgoto, com áreas totalmente cobertas por redes, não necessariamente significa tê-los universalizados. Além das questões relativas à qualidade e à continuidade dos serviços, o acesso à infra-estrutura é muitas vezes limitado pela falta de capacidade de pagamento das tarifas pela população. Diante disso, há necessidade de políticas públicas redistributívas entendidas como "o desvio e o deslocamento consciente de recursos financeiros, direitos ou outros valores entre camadas sociais e grupos da sociedade" (Windhoff-Héritier apud FREY, 2000, p. 224).

Os mecanismos de implantação de políticas públicas redistributivas, tais como fundos, subsídios e recursos a fundo perdido, são essenciais para a universalização na maioria dos municípios brasileiros, e ao longo das últimas décadas, foram responsáveis pelo incremento da cobertura da infra-estrutura. A par disso, vários autores apontam caminhos para a universalização dos serviços de água $\mathrm{e}$ esgoto.

SEROA DA MOTTA (2006), por exemplo, defende a utilização de subsídios diretos mediante programas sociais. De acordo com este autor, a tarifa dos serviços seria composta de duas partes: a primeira, fixa, em função de consumo mínimo e paga diretamente à concessionária pelo gestor do programa social; a segunda, variável, em função da diferença efetivamente consumida em relação ao consumo mínimo e com pagamento feito pelo usuário. De outra forma, PARLATORE (2000) entende que investimentos a fundo perdido, combinados ou não com mecanismos tarifários ou tributários compensatórios, podem viabilizar a universalização. 
Os recursos não onerosos, oriundos do Orçamento Geral da União são os mais representativos dos investimentos públicos no setor. Para o período 2003-2006, estes desembolsos representaram $49 \%$ do total de recursos comprometidos, com a maior parcela destinada para as regiões mais carentes e para os municípios pequenos, áreas rurais e minorias étnico-sociais (BRASIL, 2007b). Apesar de a destinação de verbas estar focada nas áreas mais deficitárias de infra-estrutura sanitária, a qualidade do gasto público é reconhecida pelo próprio governo como um dos entraves para se atingir a eficiência e a eficácia na alocação dos recursos (Id. Ibid.). A qualidade do gasto está relacionada ao uso indevido dos recursos públicos, utilização de critérios políticos na definição da prioridade dos investimentos e ausência de eficácia da infra-estrutura instalada, o que é mais uma conseqüência da fragilidade institucional do setor.

Já TUROLLA (2002) advoga que a política adequada seria a implantação de fundos de universalização por área de concessão a partir de percentual arrecadado da receita bruta operacional do prestador de serviços da área, cuja gestão caberia ao regulador local. Ainda como afirma, para as localidades onde não fosse possível levantar recursos para formação do fundo, os investimentos seriam custeados com recursos do governo federal.

No país, o subsídio cruzado é amplamente praticado mediante a agregação em escala estadual da prestação dos serviços em uma única empresa, que distribui subsídios dos municípios mais ricos para os mais pobres e das categorias de usuários de maior poder aquisitivo (indústrias e comércio) para os de menor poder (residencial). A aplicação deste mecanismo é alvo de críticas, sobretudo ante a possibilidade de inversão de prioridades dos investimentos com os subsídios alocados. Como resultado, SEROA DA MOTTA (2006) aponta que famílias com rendas superiores a dez salários mínimos têm $50 \%$ a mais de cobertura de abastecimento de água e $100 \%$ a mais de rede de esgoto do que famílias com menos de dois salários mínimos. Isto, segundo o autor, comprova a desfocalização do mecanismo de subsídios cruzados. Tal mecanismo também tem gerado disputas entre estados e municípios pois os recursos arrecadados com a cobrança em municípios superavitários destinam-se à manutenção dos serviços e ao atendimento do 
crescimento vegetativo, com o excedente transferido para outros municípios (OGERA e PHILIPPI JR., 2005).

Contudo, o desvirtuamento na aplicação dos subsídios cruzados pode estar associado a diversos fatores, como falta de controle social, ausência de transparência na aplicação e distribuição dos subsídios, e no poder decisório do prestador de serviços quanto à definição dos critérios de repartição dos subsídios. Legalmente, as políticas redistributivas devem ser definidas pelo titular dos serviços, que possui legitimidade para estabelecimento destas políticas.

Efetivamente, a tarifa deveria ser o principal mecanismo de custeio dos serviços e de alavancagem de recursos para investimento (PENA e ABICALIL, 1999). Entretanto, esta é insuficiente para atender às demandas de universalização, que exigem recursos fiscais para provisão de infra-estrutura.

De modo geral, as discussões acerca dos mecanismos redistributivos abrangem os subsídios relativos às tarifas ou à expansão das redes. Mas não se pode desconsiderar a importância do subsídio na interligação da rede de água, cujo serviço é comumente tarifado pelas concessionárias, e, portanto, se constitui num obstáculo ao acesso dos mais pobres (VARGAS, 2005). TRÉMOLET e HUNT (2006) reforçam este entendimento ao afirmarem que o impacto causado pelo subsídio à conexão é maior que aquele relacionado ao consumo. Assim, diante da atual capacidade instalada do setor, há margem de ampliação da infra-estrutura, sobretudo nas zonas urbanas, muitas cobertas integralmente por redes, mas com vazios de atendimentos localizados nos bolsões de pobreza das cidades. Este é mais um grande desafio para o setor.

Além disso, TUROLLA e OHIRA (2006) afirmam que a baixa cobertura em áreas mais pobres está relacionada também à dificuldade dos prestadores de serviço em executar corte por inadimplência, pois ao tentar proteger os mais pobres, estas políticas acabam por inibir investimentos nestas áreas.

Independentemente dos mecanismos adotados, alguns requisitos são essenciais para o êxito das políticas redistributivas. A princípio, é preciso definir o foco da política que, indubitavelmente, deve ser o atendimento aos mais pobres. A transparência é outro requisito fundamental, e tornaria possível o monitoramento da eficácia deste mecanismo (SEROA DA MOTTA, 2004). Quem subsidia, quais os 
beneficiados, qual o volume de recursos envolvidos e quais os custos de transação na alocação dos recursos, são questões a serem respondidas na aplicação destes mecanismos. Ademais, a realização de investimentos sem a definição de políticas e mecanismos claros pode levar ao desperdício de recursos públicos, além da implantação de sistemas ineficazes tanto do ponto de vista técnico como dos resultados relacionados à saúde pública.

Deve-se ainda considerar as bases federativas do Estado brasileiro e a crise fiscal que há tempo assolam estados e municípios. Desta forma, a efetividade de qualquer mecanismo redistribuitivo depende da participação direta da União no financiamento das políticas. A promoção da melhoria do saneamento básico é competência comum da União, estados e municípios. Destes entes federados, os maiores aportes de recursos provêem da União, porém estes investimentos são marcados pela instabilidade. A própria falta de marco setorial e a localização das políticas públicas do setor em diversos órgãos e ministérios ao longo das últimas décadas contribuíram para redução da eficácia dos mecanismos redistributivos.

As opções dos mecanismos apresentados mostram vantagens e desvantagens para cada alternativa e que não existe apenas uma opção para aplicação nas diferentes realidades brasileiras. $\mathrm{O}$ importante é que, em quaisquer dos mecanismos a serem utilizados, devem-se resguardar premissas institucionais fundamentais para o êxito das políticas públicas de universalização, como transparência e controle social.

\subsubsection{Desafios para a Universalização}

No Brasil o déficit dos serviços de água e esgoto é mais acentuado nas populações de baixa renda, as quais apresentam maiores problemas de saúde pública (HELLER e NASCIMENTO, 2005; PENA e ABICALIL, 1999; SILVA e MACHADO, 2001; TUROLLA e OHIRA, 2006). Este déficit evidencia características de desigualdades sob os aspectos inter-regional, renda familiar e localização do domicílio, urbano e rural. Conforme dados da PNAD 2005, retratados na Figura 5A, o abastecimento por redes, mais adequado do ponto de vista sanitário, 
é maior nas regiões Sul e Sudeste, nos extratos de renda elevados e nas áreas urbanas. Contudo, a definição de rede geral do IBGE apenas identifica se o domicílio estava ligado à rede de distribuição de água, não fornecendo informações acerca da qualidade e da continuidade do abastecimento. Portanto, os percentuais apresentados na Figura 5A podem estar sobrevalorizados quanto às reais condições de universalização.

Conforme pode ser observado, a distribuição do acesso aos serviços de esgotos por rede coletora de acordo com a região, renda e áreas urbana e rural do domicílio, mostrada na Figura 5B, acompanha o mesmo perfil apresentado quanto ao abastecimento de água por rede, com o agravante de a rede coletora ter menor cobertura. No entanto, as desigualdades de cobertura por redes de esgoto são maiores que as de redes de água. Por exemplo, quanto à distribuição regional, o Sudeste possui $\mathbf{7 7 , 4 \%}$ de cobertura por redes de esgoto enquanto as regiões Nordeste, Sul e Norte têm, respectivamente, $27 \%, 25,9 \%$ e $4 \%$ de cobertura. Da mesma forma, em relação à renda, a população com renda superior a vinte salários mínimos tem $76,6 \%$ de acesso às redes de esgoto, mais que o dobro das famílias com menos de dois salários mínimos.

A definição de rede coletora abrange ainda o esgotamento por galerias de águas pluviais, assim como o lançamento destes esgotos in natura nos corpos d'água. Ao considerar este conceito, entende-se que os índices apresentados para o esgotamento sanitário por redes estão acima dos valores reais do que seria a condição adequada, ou seja, esgotamento por redes coletoras e tratamento e disposição final. Não obstante, ressalta-se, quando viável técnica e economicamente, tanto para os serviços de água como para os de esgoto, as soluções simplificadas também são consideradas adequadas. 
Figura 5A - Distribuição no acesso a água por rede geral dos domicílios brasileiros segundo renda, região e localização.

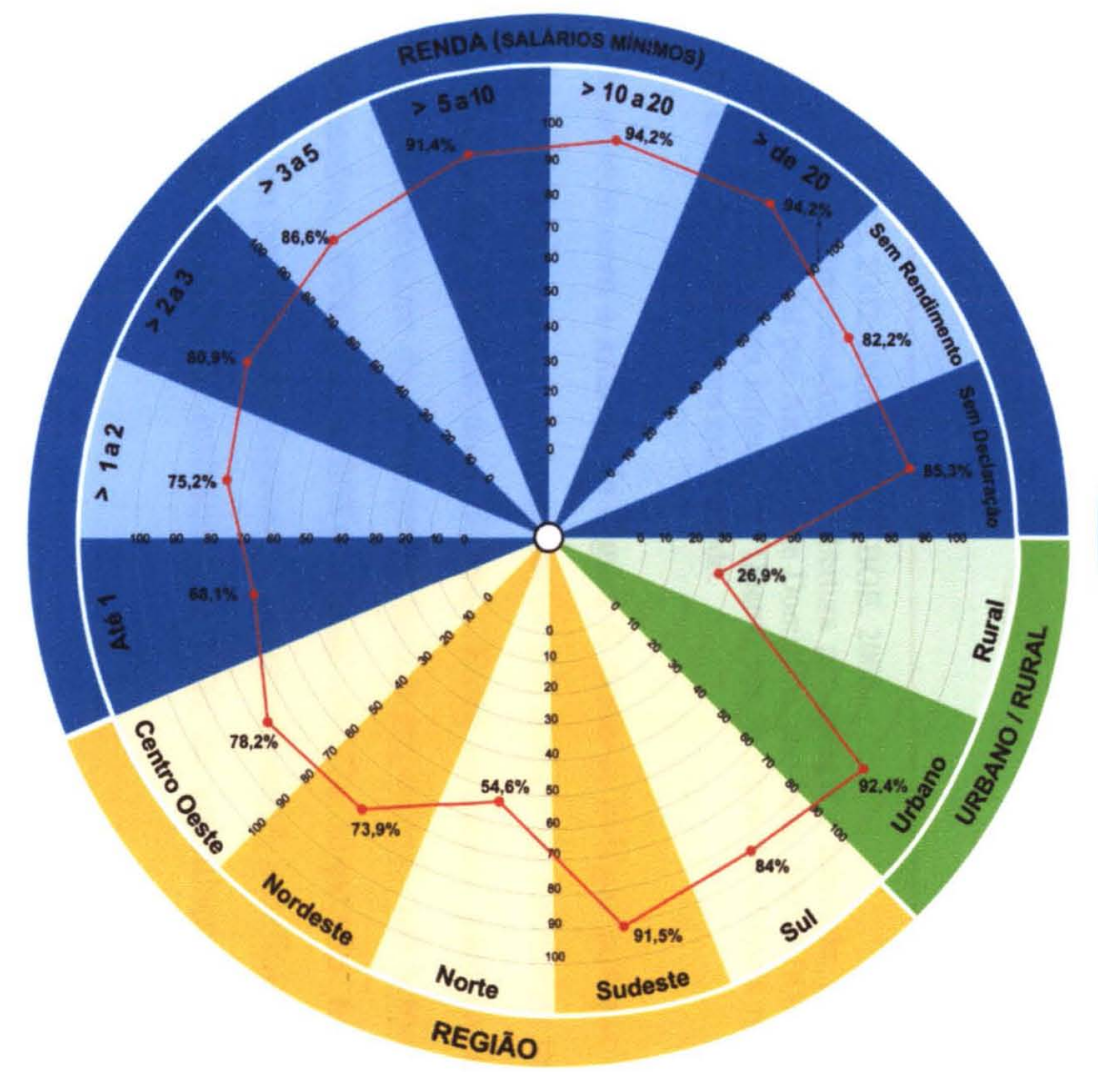

Figura 5B - Distribuição no acesso ao esgotamento sanitário por rede geral dos domićlios brasileiros segundo renda, região e localização.

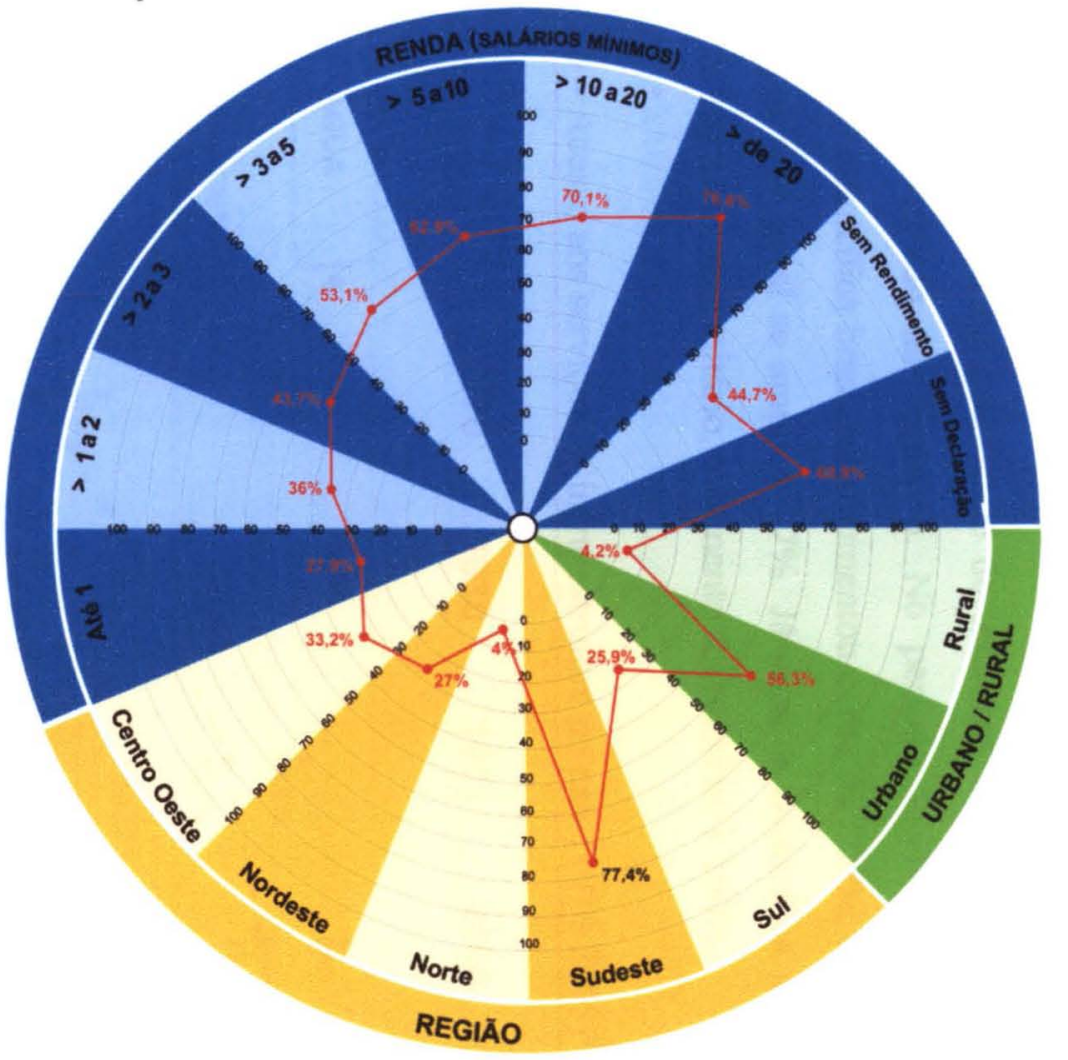

Fonte dos dados: IBGE, 2006. 
Ao se comparar o saneamento básico com os demais setores da infra-estrutura do país, tem-se que a distribuição de energia elétrica está próxima de atingir a universalização e que a telefonia apresenta ritmo de expansão bastante elevado, em virtude do incremento na quantidade de telefones móveis a partir do ano 2000, conforme demonstrado na Figura 6. No período 1991-2005, a quantidade de telefones nos domicílios brasileiros aumentou cerca de $500 \%$, enquanto a cobertura de água por rede geral se ampliou $77 \%$. Já para os domicílios atendidos por rede geral para esgotamento sanitário, o aumento foi próximo a $100 \%$.

Figura 6 - Acesso aos serviços de infra-estrutura no país (1970-2005)*.

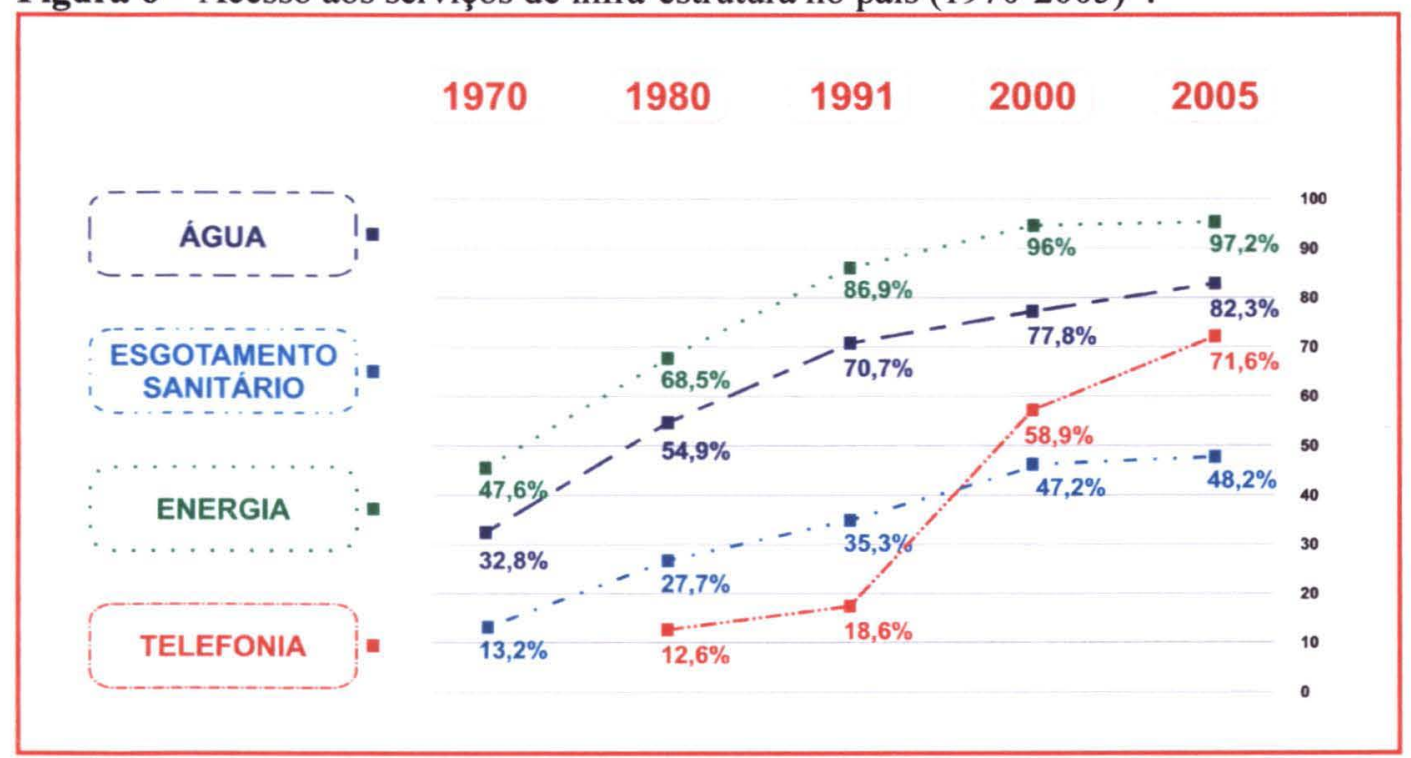

Fonte dos dados: IBGE, 2002; IBGE, 2003b; IBGE, 2006.

Nota: *Os percentuais apresentados para cobertura por energia e telefonia, ano base 2000, foram obtidos da Pesquisa Nacional por Amostras de Domicílio, ano base, 2001 (IBGE, 2002), visto que o Censo 2000 não dispunha desta informação. Quanto aos serviços de telefonia referentes ao ano de 1970, não há dados disponíveis para este período.

De acordo com a análise da Figura 6, pode-se indagar por que o atendimento dos serviços de água e esgoto não avançou em termos de cobertura tanto quanto os demais serviços de infra-estrutura no país. Entre as causas para justificar o menor avanço da infra-estrutura de saneamento básico em relação aos setores de energia e telecomunicações, ZVEIBIL (2003) aponta para a dispersão na aplicação das políticas setoriais por diversos órgãos do governo federal, indefinição da titularidade, dependência de elevados investimentos e falta de articulação intergovernamental 
para execução de reformas setoriais. Do mesmo modo, NASCIMENTO e HELLER (2005) e TONETO JÚNIOR e SAIANI (2006) advogam, entre outros, a fragmentação de políticas públicas, e problemas com concessão e regulação dos serviços como responsáveis pelo déficit do saneamento no país. Outros autores reforçam que a ausência de definição explícita na Constituição acerca da titularidade dos serviços dificulta o avanço da expansão e da melhoria da prestação dos serviços (CONFORTO, 2000; TUROLLA e OHIRA, 2006).

Além disso, os recursos necessários para a expansão dos serviços de saneamento são superiores aos dos demais setores (TUROLLA e OHIRA, 2006). Por exemplo, Haneman apud JORDAN (1998) ${ }^{14}$ afirma que os investimentos em saneamento básico são em média três a quatro vezes maiores que os de energia.

Ao longo das três últimas décadas a questão da titularidade não fez parte da agenda institucional do setor, mesmo após a aprovação da Constituição em 1988. Isto ocorreu preliminarmente porque os progressos na cobertura dos serviços, sobretudo no abastecimento de água, contemplaram os interesses dos grandes municípios pertencentes aos sistemas integrados e metropolitanos. Ademais, diante da fragilidade dos instrumentos contratuais, os prestadores de serviço assumiram as funções de regulação e de elaboração de políticas. Assim, foi-lhes garantida autonomia para definição dos rumos das concessões que, apesar de nem sempre estarem em sintonia com os objetivos da sociedade, evitavam conflitos com os titulares. Efetivamente, a ausência de participação dos municípios repercutiu de forma negativa nos resultados alcançados, mas ao mesmo tempo, estes entes federados não detinham expertise para o exercício da titularidade, gerando um círculo vicioso na definição dos papéis institucionais.

Porém, com a escassez de recursos para realização de investimentos, principalmente para o tratamento de esgotos, e o término dos contratos de concessão, situação ocorrida desde o final dos anos 1990, os municípios passaram a exigir seus direitos e assumir as prerrogativas de titular dos serviços.

As disputas em torno da titularidade estão focadas nos sistemas integrados e nas regiões metropolitanas, consideradas pelos Estados como sistemas de interesse

14 Não são explicitados nesta publicação os critérios de cálculo para dimensionamento dos investimentos em saneamento. 
comum, os quais avocam para si a titularidade. Mesmo diante desta indefinição, a partir de 2003, o governo federal passou a exigir a regularização das concessões como pré-requisito para liberação de empréstimos às concessionárias de água e esgoto (BRASIL, 2007b). Esta medida obrigou alguns estados e municípios a assinar contratos de concessão, com reconhecimento da titularidade municipal. No entanto, a medida foi insuficiente para amenizar as tensões políticas entre os entes federados.

Deve-se ressaltar que o debate sobre titularidade não se configura objeto desta pesquisa. Mas como a questão se constitui em um dos grandes desafios do setor, é preciso avançar rumo à universalização, independente desta definição.

Não obstante a titularidade ser considerada por diversos autores o ponto central dos problemas do setor, essa discussão relegou a segundo plano outros temas fundamentais para o desenvolvimento do saneamento como planejamento, regulação, operação e financiamento (MENDES et al., 2006).

A titularidade vem sendo debatida pelo Supremo Tribunal Federal, em duas Ações Diretas de Inconstitucionalidade que tramitam em processo de julgamento: ADIN $n^{\circ} 1.842$, referente à ação impetrada pelo Partido Democrático Trabàlhista contra o Governo e a Assembléia Legislativa do Estado do Rio de Janeiro; e a ADIN $\mathrm{n}^{\circ}$ 2.077, argüída pelo Partido dos Trabalhadores contra a Assembléia Legislativa do Estado da Bahia.

A indefinição acerca da titularidade também contribui para o atraso no estabelecimento de políticas públicas para o setor (PIRES e PICCININI, 1999). A ausência de políticas adequadas para os serviços de água e esgoto é apontada por LEE (2000) como característica comum na América Latina, e tem ocasionado conflitos e competição pela água em decorrência do seu uso intensivo para transporte e diluição de resíduos, principalmente nas áreas mais urbanizadas.

No Brasil, a falta de política setorial consistente para o saneamento básico se verifica desde o final dos anos 1980, quando do término do PLANASA, última política nacional de longo prazo. Dos setores da infra-estrutura, o saneamento foi o último a dispor de política nacional, mediante a Lei $\mathrm{n}^{0} 11.445$, promulgada em janeiro de 2007, fato este que repercutirá nas políticas subnacionais. Efetivamente, a desarticulação das políticas setoriais de estados e municípios colabora para agravar ainda mais o quadro institucional do setor (OGERA e PHILIPPI JR, 2005). Já para as 
áreas de interface do saneamento básico, como as políticas sociais de saúde pública, meio ambiente, recursos hídricos, entre outros, o país dispõe de diversas políticas públicas.

A Figura 7 demonstra a evolução das principais políticas relacionadas ao saneamento básico e de infra-estrutura do país. Nesta figura não foram consideradas as legislações municipais de saneamento básico, pois tais políticas públicas, em geral, encontram-se diluídas nas leis orgânicas dos municípios.

Figura 7 - Evolução das políticas sociais, de saneamento básico e de infra-estrutura.

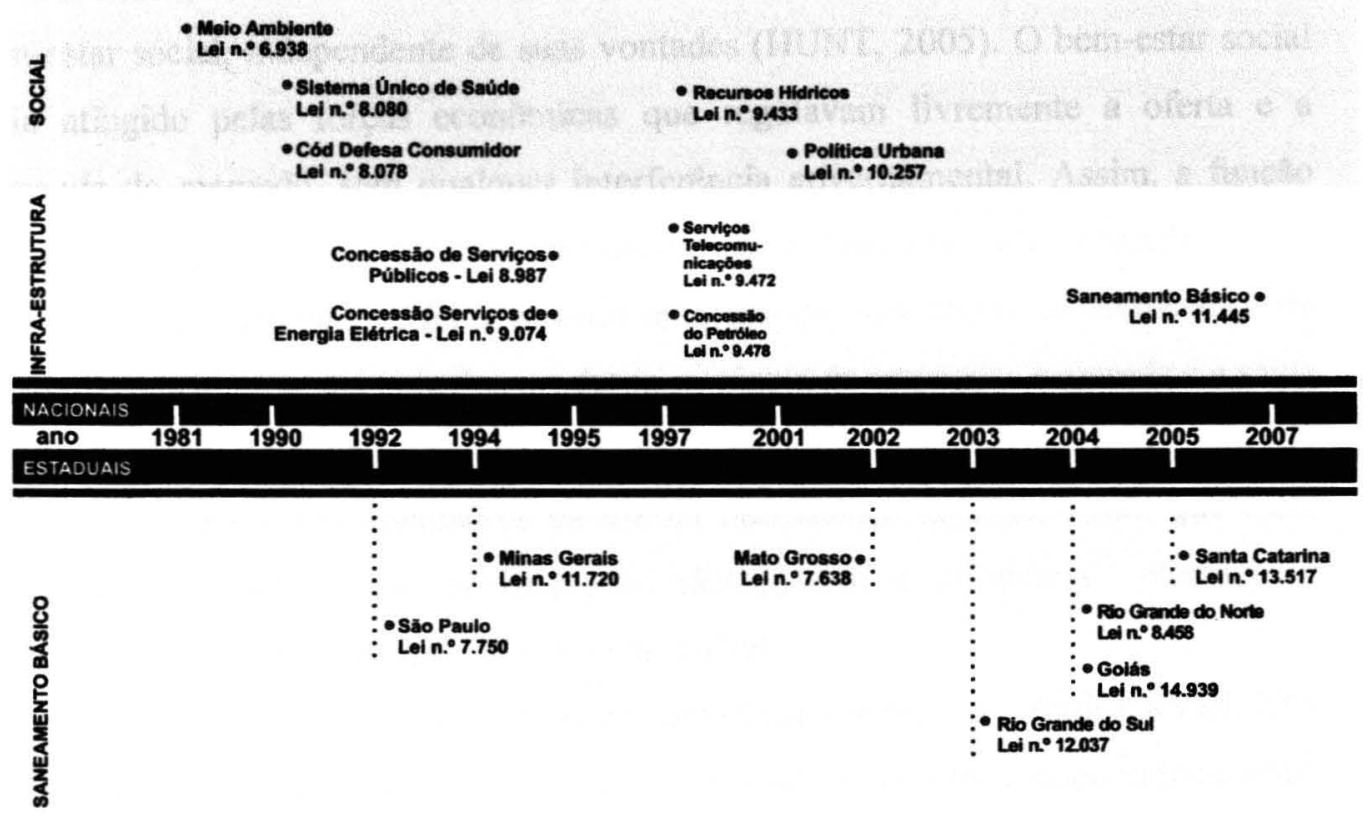

Fonte: Elaboração do autor.

Observa-se ainda que no saneamento básico houve retardo de cerca de uma década em relação aos demais serviços de infra-estrutura para dispor do seu próprio marco legal, o que demonstra a falta de prioridade política com o setor. Como conseqüência, no âmbito estadual são reportadas somente sete políticas públicas, entre os 26 Estados e o Distrito Federal. Ademais, nem todas estas políticas estão regulamentadas ou implementadas. 


\subsection{REGULAÇÃO}

\subsubsection{Origem da Regulação}

As bases doutrinárias da corrente majoritária do pensamento econômico moderno, denominada de escola neoclássica, tiveram em Adam Smith um dos seus principais precursores. Para Adam Smith, a felicidade das pessoas tinha origem na riqueza material e elas eram conduzidas por uma "mão invisível" para a promoção do bem-estar social, independente de suas vontades (HUNT, 2005). O bem-estar social seria atingido pelas forças econômicas que regulavam livremente a oferta e a demanda do mercado, sem qualquer interferência governamental. Assim, a função primordial do governo era garantir e promover a livre competição no mercado.

Na competição perfeita, haveria uma grande quantidade de ofertantes e de demandantes, homogeneidade dos produtos, ausência de restrições à entrada e à saída das firmas e todos teriam informações completas sobre as condições do mercado (PHILLIPS, 1993). Os defensores da escola neoclássica argumentavam que estas condições permitiriam que as empresas alcançassem a eficiência ${ }^{15}$ alocativa e produtiva e, conseqüentemente, o bem-estar social.

Contudo, as sucessivas crises do capitalismo durante os séculos XVIII, XIX e início do século XX demonstraram que os pressupostos da livre concorrência eram inconsistentes e não representavam a realidade econômica. Estes problemas foram denominados de falhas de mercado e impossibilitavam o alcance de suas condições ótimas. Destas falhas, as principais são o poder de mercado, também designado de poder do monopólio, os bens públicos e as externalidades. Além disso, a evolução da teoria econômica agregou a assimetria de informações como falha determinante para o funcionamento dos mercados.

\footnotetext{
${ }^{15}$ A eficiência alocativa decorre da igualdade entre o preço oferecido no mercado e o custo marginal da firma para produzir a última unidade do produto ou serviço (FARINA et al., 1997). Já a eficiência produtiva é dividida em estática e dinâmica. $\mathrm{Na}$ eficiência produtiva estática, o custo total de produção ocorre ao menor valor possível enquanto na dinâmica são adotadas tecnologias mais avançadas para a produção de novos produtos e melhoria nos processos (Id. Ibid.).
} 
O monopólio se caracteriza pela atuação de uma ou poucas empresas de forma exclusiva em uma atividade econômica. Especificamente em relação aos serviços públicos, como abastecimento de água e distribuição de energia elétrica, nos quais é inviável a atuação de mais de uma empresa em um dado mercado, o monopólio é denominado natural. A existência de monopólios naturais dá-se, sobretudo, em virtude da existência de economias de escala e/ou de escopo ${ }^{16}$, presentes na maioria dos serviços públicos de infra-estrutura.

Como nos monopólios naturais dos serviços de utilidade pública a demanda é inelástica e não há ameaça de competição, as empresas monopolistas não oferecem incentivos para reduzir custos e melhorar a eficiência (JOURAVLEV, 2001a). Desta forma, as vantagens econômicas de se ter uma única empresa produzindo bens e serviços são desperdiçadas em decorrência do aumento dos preços e da diminuição da qualidade dos serviços, resultando na apropriação de lucros excessivos pelos monopólios.

Quando a produção de bens e serviços causa impactos positivos e negativos a terceiros, não relacionados à atividade econômica, tem-se a ocorrência de externalidades. Em geral, o custo da externalidade não é internalizado pela empresa, e, a depender do impacto, o custo social é maior do que o custo privado do bem ou serviço. Nesta situação, as empresas atuam de forma oportunística aumentando a produção do bem ou serviço, pois parte do custo de produção é transferido para a sociedade (VARGAS et al., 2002). Das externalidades ambientais, as de caráter negativo são as mais freqüentes. Ao emitir gases em quantidade e concentração não admissíveis, uma indústria estará poluindo o meio ambiente, e ocasionando, por exemplo, doenças respiratórias na população circunvizinha, entre outros problemas. Como resultado, as despesas do tratamento dos doentes e de todos os impactos

\footnotetext{
${ }^{16}$ As economias de escala decorrem da existência de elevados custos fixos na produção de um bem, independente da quantidade produzida (PINHEIRO e SADDI, 2005). Então, quanto maior a quantidade de unidades produzidas, menor será o custo médio. Trata-se do exemplo das usinas de geração hidrelétrica, onde a construção de barragens, de custo fixo inicial bastante elevado, independe da quantidade de energia a ser produzida em qualquer etapa da operação do sistema. Contudo, nas economias de escopo, a produção de mais de um bem ou serviço apresenta custos comuns quando realizados por uma só empresa (Ib. Idib.). Este é o caso das empresas de saneamento básico que para executar serviços de natureza diversa, produção e distribuição de água tratada, e coleta e tratamento dos esgotos, compartilham estruturas operacionais comuns, como apoio administrativo, atendimento ao usuário, entre outros. Conseqüentemente, os custos dos serviços são menores caso fossem realizados por empresas diferentes.
} 
econômicos e não econômicos serão custeadas pela própria sociedade, já que a empresa não realizou o tratamento dos efluentes gasosos, e, por conseguinte, não incorporou estes custos ao seu produto.

Diante das características dos bens e serviços públicos, como a não exclusividade e a não rivalidade, o mercado competitivo não se forma para a produção destes bens e serviços. $\mathrm{O}$ acesso aos sistemas de saúde e de educação são casos típicos, pois na ausência de prestadores privados ou na incapacidade do cidadão de custear o serviço, o Estado não pode se isentar de provê-lo de forma adequada e universal.

Por último, a ausência de informações sobre as reais condições do mercado não permite que os agentes econômicos, sejam eles produtores ou consumidores, tomem decisões perfeitas, conseqüentemente não levando à alocação eficiente dos recursos disponíveis. Por exemplo, as empresas usam informações sobre custos e qualidade de seus produtos de forma estratégica na determinação dos preços finais aos consumidores. Já estes, por distinguirem em geral apenas as características estéticas dos produtos, se encontram numa situação de hipossuficiência em relação aos produtores.

Portanto, na presença de falhas de mercado, a intervenção do Estado na economia é necessária para:

- Simular competição nos mercados em todos os setores sujeitos a falhas de mercado (FARINA et al., 1997);

- Coibir a fixação de preços abusivos pelos monopólios;

- Prover bens e serviços públicos de natureza essencial onde não há atratividade, lucro baixo e risco elevado, para o setor privado (VARGAS et al., 2002);

- Regulamentar e controlar a prestação de serviços públicos de natureza essencial quanto às tarifas e à qualidade dos serviços;

- Reduzir a diferença entre os custos privado e social causados pelas externalidades (MAJONE, 1996). 
A intervenção do Estado dá-se por meio da regulação ou pela propriedade estatal $^{17}$, entendida com a provisão direta de bens e serviços por empresas estatais. Na Figura 8 apresentam-se esquematicamente os pressupostos neoclássicos para intervenção do Estado na economia.

${ }^{17}$ A propriedade pública será discutida com mais detalhes nas seções seguintes. 
Figura 8 - Pressupostos para intervenção do Estado na economia.

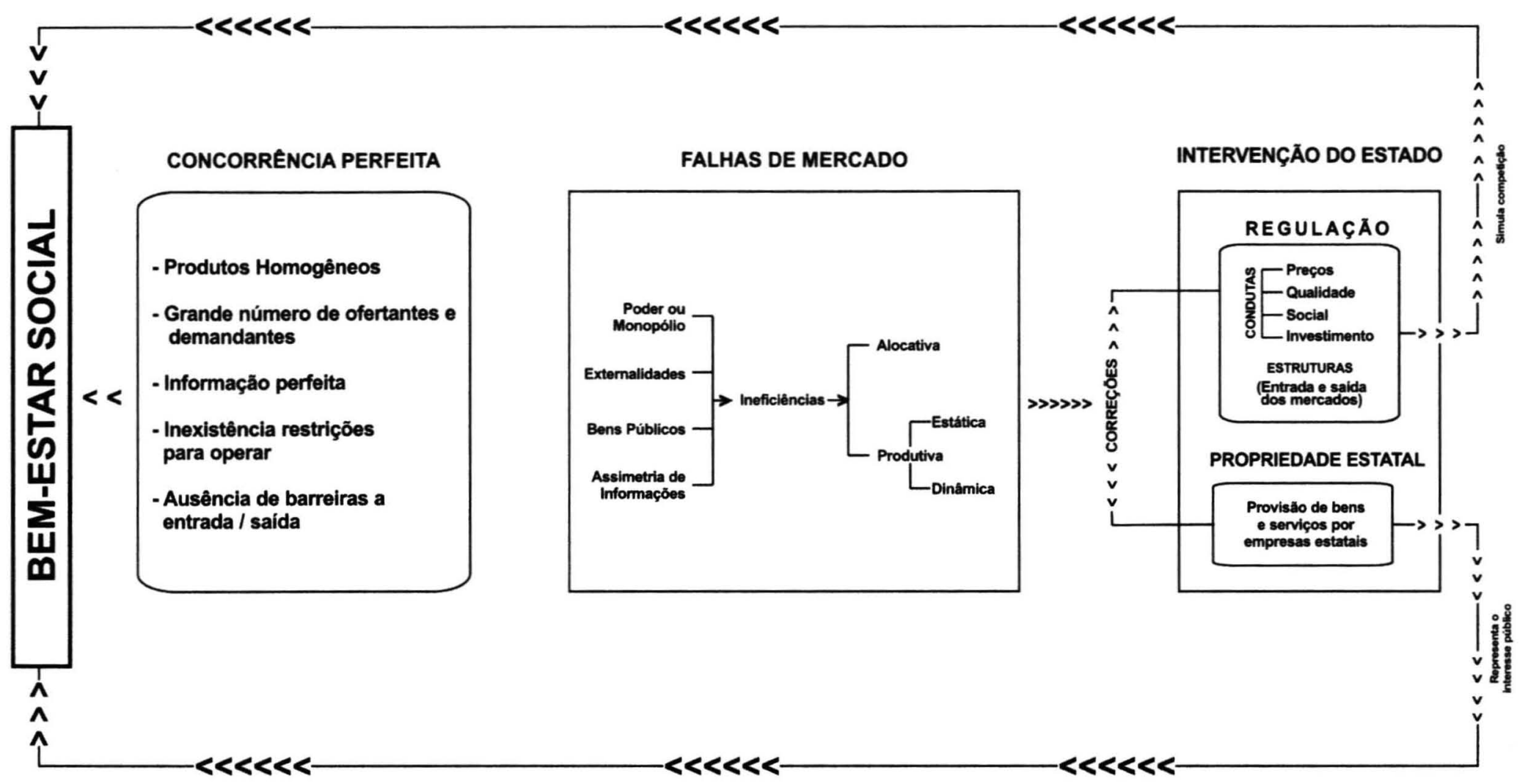

Fonte: Elaboração do autor. 
Diversos autores conceituam a regulação como a restrição das decisões dos agentes econômicos por meio do poder de coerção do Estado (VISCUSI et al., 2005, p. 357; PINHEIRO e SADDI, 2005). Esta visão, focada no controle das atividades econômicas, limita o escopo da regulação às transações de mercado. Por outro lado, o entendimento dos juristas se contrapõe à visão econômica em dois aspectos fundamentais. Primeiro no que diz respeito à abrangência: a regulação é definida como a atuação do Estado não só na ordem econômica, mas também na ordem social com a finalidade de proteger interesse público (DI PIETRO, 2004). Segundo, a autoridade do Estado passa a ser exercida de forma a mediar os conflitos e interesses envolvidos ao invés do uso do poder coercitivo (NAVES, 2004; MARQUES NETO, 2005).

$\mathrm{Na}$ presente pesquisa, o conceito de regulação é entendido como a intervenção do Estado nas ordens econômica e social com a finalidade de se alcançar eficiência e equidade, traduzida como universalização na provisão de bens e serviços públicos de natureza essencial, por parte de prestadores de serviço estatais e privados.

Para melhor compreender a natureza e os objetivos da regulação, é necessária abordagem geral da evolução da teoria da regulação.

\subsubsection{Teorias sobre a Regulação}

Até o início da segunda metade do século $\mathrm{XX}$, o interesse público era $\mathrm{o}$ principal fundamento para justificar a regulação. De acordo com a Teoria do Interesse Público, a regulação era demandada pela sociedade para corrigir as falhas de mercado e prover o bem-estar social, a um baixo custo. Como seus pressupostos apenas indicavam quando a regulação deveria ocorrer, a TIP foi também denominada de teoria normativa da regulação e originou-se nos Estados Unidos no final do século XIX com a criação da Comissão de Comércio Interestadual para regular o transporte ferroviário. Entretanto, somente após os anos 1930, com a crise econômica internacional e a formação do Estado do Bem-Estar Social, é que o desenvolvimento 
das instituições reguladoras foi impulsionado nos Estados Unidos e nos países centrais (VARGAS, 2005).

Esta teoria sofreu críticas bastante incisivas, pois a regulação se deu principalmente em setores nos quais não havia falhas de mercado como táxis, transporte rodoviário de cargas e indústria de seguros (POSNER, 2004; VISCUSI, et al., 2005). Ainda no período de predomínio da Teoria do Interesse Público, segundo POSNER (2004), muitas empresas obtiveram vantagens regulatórias, principalmente em relação à limitação da concorrência nos setores regulados.

Diante deste contexto e em contraposição à TIP, é formulada a Teoria da Captura. Esta, apesar de reconhecer as boas intenções da regulação em promover o interesse público, relata que a TIP é desvirtuada por falhas de governo, resultando em sua captura pela indústria. A regulação é comparada a um ciclo de vida no qual os reguladores buscam originalmente o interesse público, posteriormente se acomodam, e por fim atendem aos interesses dos regulados (PHILLIPS, 1993).

A Teoria da Captura foi criticada em dois aspectos. Primeiro, a regulação era vista como uma "caixa-preta", focada nos resultados, e não considerava os procedimentos envolvidos no processo regulatório (SALGADO, 2003). Segundo, a teoria da captura não conseguia explicar por que em alguns setores regulados, usuários e pequenos produtores eram favorecidos por subsídios cruzados (VISCUSI et al., 2005).

No início dos anos 1970, George Stigler, um economista pertencente à escola de Chicago publica artigo intitulado A teoria econômica da regulação o qual se constitui em um novo arcabouço teórico da regulação. STIGLER (2004, p. 25) defende a tese de que, em geral, "a regulação é adquirida pela indústria, além de concebida e operada fundamentalmente em seu benefício". Segundo este autor, os interesses das indústrias em obter políticas regulatórias do Estado estão relacionados à obtenção de subvenções diretas em dinheiro, controle da entrada de novos concorrentes, limitações a produtos substitutos e complementares, e fixação de preços (Id. Ibid.).

Além disso, as evidências de Stigler apontavam que a regulação apresentava alto custo para a sociedade, seja pela manutenção de cartéis ineficientes, seja por elevados níveis tarifários nos setores regulados. Dessa forma, Stigler se 
contrapõe parcialmente à Teoria da Captura, ao afirmar que não há interesse público envolvido e que a regulação é capturada pelos produtores desde sua origem (SALGADO, 2003). Esta teoria é também conhecida como teoria positiva da regulação, pois aponta quais os resultados da atividade reguladora.

Posteriormente, a Teoria Econômica da Regulação foi complementada por Peltzman e Becker. De acordo com PELTZMAN (2004), as vantagens auferidas pela regulação não eram exclusivas dos produtores e havia disputa entre grupos de interesse pelos ganhos da regulação. Nesta disputa, os produtores, em menor número e mais organizados, levavam os principais beneficios da regulação, entretanto, formavam uma coalizão com pequenos grupos de usuários, com os quais eram repartidos os demais ganhos. Assim, Peltzman procurou explicar a distribuição de subsídios cruzados como meio de equilibrar a distribuição de rendas da regulação entre produtores e consumidores (MAJONE, 1996). Já Becker afirmou que poderia haver ganhos com a regulação em virtude da correção de falhas de mercado, o que justificava em parte a Teoria do Interesse Público (VISCUSI et al., 2005). No entanto, a regulação era determinada principalmente pela influência dos grupos de interesse em pressionar legisladores e reguladores (Id. Ibid.). Em síntese, as visões de Stigler, Peltzman e Becker abordam sob diferentes ângulos os impactos causados pelos grupos de pressão no processo regulatório.

A TER afirmava ainda que, quando os grupos de pressão reagem contra os desperdícios causados pela regulação ou quando o custo do apoio às políticas regulatórias é maior do que a renda extraída por estes grupos, acontece a desregulação (HAGG, 1997). Na verdade, a TER reafirma os postulados básicos da economia neoclássica, ao enfatizar a crença na livre competição como melhor alternativa para se atingir o bem-estar social (SALGADO, 2003). Neste contexto, ocorreram profundas mudanças na intervenção do Estado na economia de todo o mundo a partir dos anos 1970, por meio de políticas de desregulação e de privatização, impulsionadas pelos governos conservadores de Ronald Reagan nos Estados Unidos e de Margareth Tatcher na Inglaterra, e pelos organismos multilaterais como o Banco Mundial e o Fundo Monetário Internacional.

Apesar de as Teorias do Interesse Público e Econômica da Regulação serem consideradas antagônicas, HAGG (1997) afirma que ambas compreendem etapas 
históricas de desenvolvimento do pensamento econômico. MAJONE (1996) corrobora esta afirmação, ao defender que as teorias são mais complementares entre si do que mutuamente exclusivas. Entretanto, ambas as teorias são limitadas, pois ignoram o ambiente institucional no qual os reguladores operam, o que torna impossível explicar o comportamento destes atores e da própria dinâmica do processo regulatório (Id. Ibid.).

O estudo do ambiente institucional coube aos economistas neoclássicos, que fundamentados na microeconomia desenvolveram arcabouço teórico com base na análise dos custos de transação, direitos de propriedade e falhas de organização, os quais afetavam as decisões dos agentes econômicos. Este novo pensamento da teoria da regulação foi denominado de Novo Institucionalismo.

A análise dos custos de transação parte da premissa de que os contratos são incompletos, o que permite aos contratantes agir de forma oportunista para obter vantagens na concepção e elaboração (ex-ante) e na execução (ex-post) dos contratos. Os custos ex-ante estão associados às etapas anteriores à formalização dos contratos como elaboração e negociação de minutas e definição de garantias contratuais (WILLIAMSON, 1985). Já os custos ex-post relacionam-se ao acompanhamento dos contratos pelo regulador e regulado, possíveis renegociações e custos devido a disputas no âmbito do poder judiciário (VARGAS et al., 2002).

Os direitos de propriedade são compreendidos como "um sistema em que itens de valor na economia, sejam recursos ou bens, têm proprietários específicos que podem dispor deles como queiram" (KRUGMAN e WELLS, 2007, p. 237). Assim, como os bens ambientais são de uso comum e domínio público, o mercado não pode alocar de forma racional o consumo destes bens (MARTINS e FELICIDADE, 2001).

VARGAS et al. (2002) consideram que a principal contribuição do novo institucionalismo foi a análise conjunta das falhas de mercado, de governo e de organização, com a definição de mecanismos de governança e de incentivos regulatórios para minimização e correção dos principais impactos adversos destas falhas na atividade regulatória. 
Para os defensores do Novo Institucionalismo, o desenho institucional é identificado como fundamental para o exercício da atividade reguladora (SALGADO, 2003). O desenho é definido como um conjunto de instrumentos de governança regulatória capazes de prover incentivos adequados para que os reguladores não sejam capturados ou não se desvirtuem das suas funções. Estes instrumentos compreendem os mandatos dos dirigentes das agências e salvaguardas contra demissão voluntária, mecanismos de transparência para decisões regulatórias, autonomia financeira e administrativa, entre outros, discutidos nas seções seguintes.

\subsubsection{Propriedade Estatal}

Conforme abordado, a teoria econômica preconiza como correção para as falhas de mercado, a propriedade estatal ou a regulação. Na propriedade estatal, o interesse público estaria representado pelo Estado, que seria responsável pela provisão direta de bens e serviços. Nestas circunstâncias, o objeto da atividade econômica seria a maximização do bem-estar social. Como a provisão estatal representava o interesse público, não havia preocupação quanto à proteção dos direitos dos usuários e caso ocorrese prejuízo na atividade econômica, o ônus seria repartido com a sociedade (MARQUES NETO, 2005).

Além da correção das falhas de mercado, a provisão estatal foi utilizada como instrumento de desenvolvimento econômico, principalmente na Europa e na América Latina, onde a atividade econômica estatal avançou até mesmo sobre áreas passíveis de competição, como mineração, siderurgia, aviação, entre outros. Neste contexto, havia um entendimento de que, além de proteger o interesse público, a propriedade estatal propiciaria instrumentos para o Estado planejar a economia (MAJONE, 2006). 
No Brasil, apesar do modelo de provisão estatal ter sido estimulado como instrumento de desenvolvimento nacional a partir dos anos 1950 , foi somente após a edição do Decreto-Lei n ${ }^{\circ} 200$, em 1967, que criou empresas públicas e de economia mista, é que o modelo se tornou determinante na execução das políticas públicas (SILVA, 2004). Neste período, foram estabelecidas empresas estatais para provisão de serviços públicos por rede nas áreas de telefonia, energia elétrica e saneamento básico (concessionárias estaduais de saneamento básico). No país, a despeito destas empresas terem alcançado enorme avanço da infra-estrutura, sobretudo em termos de expansão das redes, a regulação autônoma, caso existente à época, poderia ter alavancado ainda mais os indicadores de cobertura para níveis próximos à universalização.

Não obstante a propriedade estatal ser considerada uma alternativa à regulação, MARQUES NETO (2005) apresenta vários argumentos para justificar a regulação de empresas estatais: os interesses das empresas e de seus controladores não necessariamente representam o interesse público; não existe divisão de papéis entre regulado e regulador; e, por ser a regulação uma atividade tipicamente estatal, há incompatibilidade com o regime jurídico das empresas estatais ${ }^{18}$.

Especificamente para o setor de água e esgoto do país, exitem também outros aspectos que podem justificar a regulação de empresas estatais:

- Uso da empresa para fins políticos ou privados;

- Baixa eficiência técnica-operacional da maioria dos prestadores de serviço;

- Participação no mercado acionário de algumas empresas estatais. Tal fato pode resultar em maiores exigências quanto à realização de lucros por parte dos acionistas em detrimento da modicidade tarifária;

- Existência de previsão legal para regulação dos serviços, sem a qual se tornam nulos os contratos de serviços concessionados (BRASIL, 2007a).

\footnotetext{
${ }^{18}$ As empresas estatais, cuja maioria é representada por sociedades de economia mista, são consideradas pela legislação (Decreto-Lei $\mathrm{n}^{\circ}$ 900, de 1969) "entidades dotadas de personalidade jurídica de direito privado, criada por lei para a exploração de atividade econômica, sob a forma de sociedade anônima, cujas ações com direito a voto pertençam em sua maioria à União ou a entidade da Administração Indireta" (o destaque é nosso).
} 
Efetivamente, alguns dos problemas citados devem-se à frágil institucionalidade do setor, que compreende ausência de legislação, multiplicidade de agentes articuladores no âmbito do governo federal, omissão dos municípios quanto ao papel de titular dos serviços e falta de regulação dos serviços.

A regulação de empresas estatais também se constitui em resgate da cidadania, pois a mistura de papéis entre operador e titular dos serviços alijou a sociedade do controle dos serviços públicos (INFURB, 1995). Com isso, surgiram consequiências para a prestação dos serviços, pois na ausência de cobrança por expansão e por melhoria da qualidade, houve transferência parcial das ineficiências à população por meio de tarifas elevadas.

Apesar da necessidade da regulação de empresas estatais, GROOM et al. (2006) relatam dificuldades para esta atuação em virtude da falta de instrumentos de punição e de incentivo semelhantes ao da regulação de empresas privadas, inibindo resultados efetivos. Além disso, os governos não diferenciam regulação da propriedade da empresa e das políticas públicas. Ao analisar a regulação de empresas públicas de água e esgoto na Finlândia, VINARRI (2006) corrobora este entendimento ao afirmar que esta atividade tem sido mais leve do que a de empresas privadas, por considerar-se que as estatais maximizam o bem-estar social, agem em prol do interesse público e corrigem falhas de mercado.

A provisão dos serviços por empresas estatais no país ainda é majoritária em setores da infra-estrutura, como o petróleo e o saneamento básico. Não é foco desta pesquisa, porém, discutir vantagens e desvantagens da propriedade estatal ou da iniciativa privada, não obstante reconhecer que ambas as participações cumprem papéis fundamentais e diferentes na provisão da infra-estrutura brasileira. $\mathrm{O}$ que se quer garantir é que, independentemente da propriedade dos ativos, seja pública ou privada, deve ser assegurada à regulação dos serviços como forma de preservar o interesse público. 


\subsubsection{Políticas de Estado, de Governo e Regulatória}

A definição de metas, objetivos e do próprio formato da regulação suscita questionamentos sobre os papéis do Estado, do governo e da agência reguladora. Qual a função das políticas de Estado? Quais os limites entre as políticas governamentais e regulatória e suas interfaces com as políticas públicas setoriais? Quem define a política regulatória? Estas definições são importantes até mesmo para diferenciar os problemas passíveis de ser resolvidos por meio de medidas regulatórias daqueles que envolvam soluções de políticas públicas (EHRHARDT et al., 2007).

Em decorrência da complexidade do tema, e principalmente por sua incipiência no Brasil, essas questões têm ocasionado conflitos entre governo e agências reguladoras. $\mathrm{Na}$ verdade, as políticas de governo e regulatória devem ser estabelecidas no âmbito das políticas de Estado, e somente a elas é que estão subordinadas. Já a política governamental pode até condicionar a política regulatória, no sentido de definir metas e objetivos das políticas públicas setoriais, mas não pode substituí-las.

Mesmo na Inglaterra, considerada modelo de regulação, após uma década de privatização dos serviços públicos, a reforma regulatória do governo trabalhista precisou enfatizar estes limites e os objetivos regulatórios, deixando evidente que caberia ao governo, e não aos reguladores, fixar metas sociais e orientações gerais para os reguladores para atuação na implementação de políticas de equidade (Department of Trade and Industry apud JONES, 2001).

Especificamente em relação aos serviços de saneamento básico, as políticas de Estado e governamental devem fixar objetivos, princípios e metas, assim como definir quem cumprirá estes objetivos (EHRHARDT et al., 2007). No referente à universalização deste setor, VARGAS (2005) defende que os objetivos e metas sociais devem ser definidos pelo poder concedente, no caso, o governo, e os resultados perseguidos pelas agências reguladoras em articulação com os municípios. Porém, a atuação dos reguladores não se limita somente ao cumprimento da 
regulação disposta em lei. Compete a estes entes também a complementação dos instrumentos legais por meio de regulamentos próprios (MENDES, 2002).

Como exemplo para este setor, TRÉMOLET e HUNT (2006) citam a política pública para expansão do atendimento por saneamento básico aos mais pobres na África do Sul que estabeleceu como meta o atendimento a oito milhões de pessoas no período de oito anos. À regulação coube a definição de metas específicas para os prestadores de serviço e a aplicação de penalidades em caso de não cumprimento destas metas (Id. Ibid.).

$\mathrm{Na}$ Figura 9, podem ser identificados, de forma sucinta, os diferentes campos de atuação de cada política, juntamente com suas características específicas. 
Figura 9 - Políticas de Estado, governamental e regulatória.

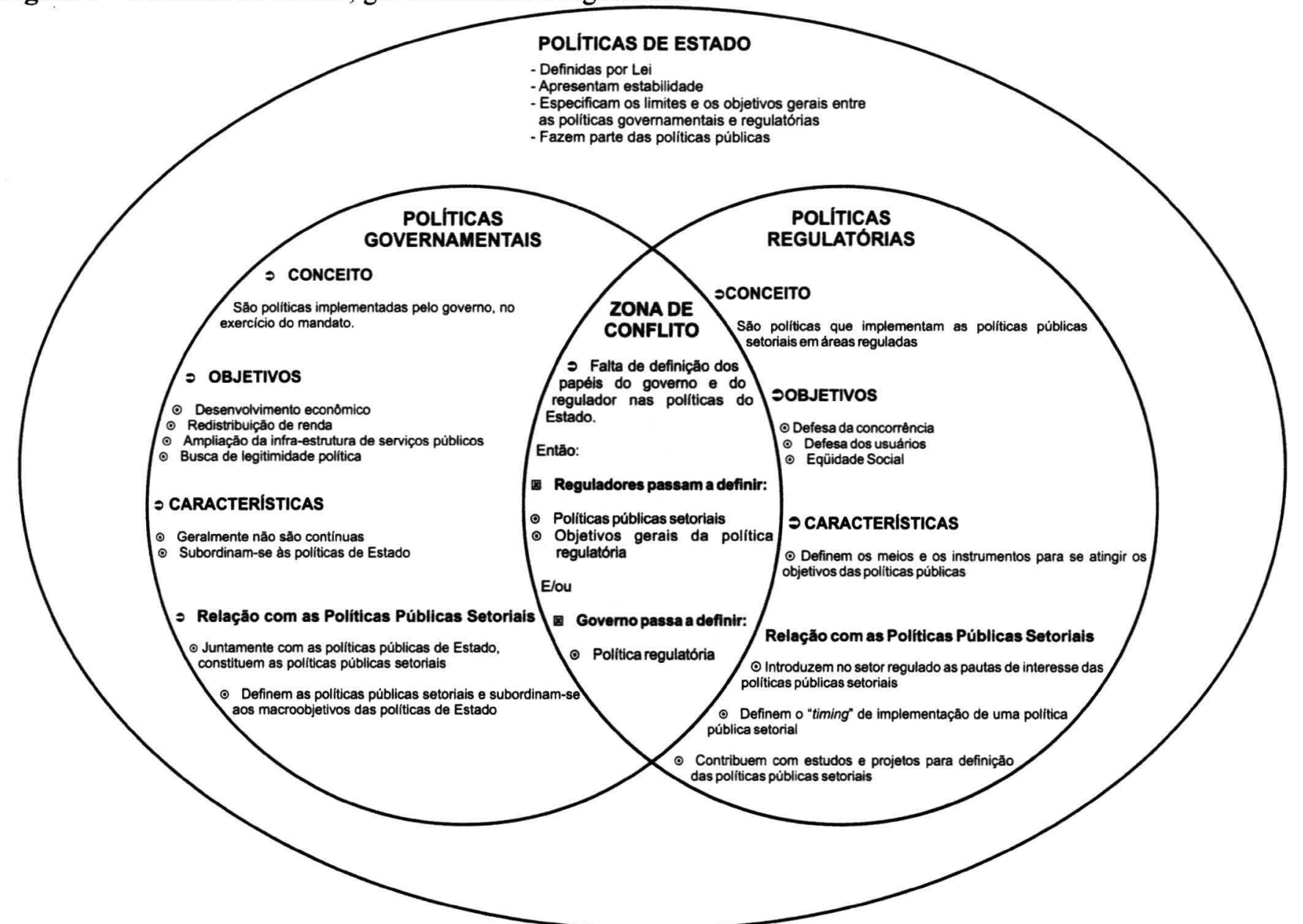

Fonte dos dados: MAJONE, 1996; MARQUES NETO, 2005; PECI, 2007; TRÉMOLET e HUNT, 2006. 
A Figura 9 não evidencia de forma clara a fronteira de atuação entre as políticas de Estado, de governo e regulatória. TRÉMOLET e HUNT (2006) reiteram a dificuldade de definir os limites entre as políticas públicas e regulatórias, as quais, segundo estes autores, dependem da credibilidade e legitimidade do regulador em tomar ou recomendar decisões que resultem em efeitos nas políticas públicas. Para melhor ilustrar o papel de cada política, é apresentado no Quadro 4 o escopo da política de telecomunicações ${ }^{19}$.

\footnotetext{
${ }^{19}$ Entretanto deve-se destacar que o Quadro 4 apresenta apenas uma amostra das funções das políticas governamental e regulatória para o setor de telecomunicações, cujo enfoque da análise está voltado para algumas das atribuições definidas nas Leis $\mathrm{n}^{\text {os }} 9.472 / 97$ e $9.998 / 2000$. Por exemplo, a política regulatória envolve ainda a regulamentação deste setor, a outorga de concessões, permissões e autorizações, entre outros, conforme previsto no art. 19 da Lei $\mathrm{n}^{\circ}$ 9.472/97.
} 
Quadro 4 - Políticas e papéis do Estado, governo e regulador na universalização do setor de telecomunicações.

\begin{tabular}{|c|c|c|c|c|}
\hline \multicolumn{2}{|c|}{ Universalização } & \multirow[b]{2}{*}{$\begin{array}{l}\text { Estado } \\
\text { Lei } \mathbf{n}^{\circ} \text { 9.472/1997 } \\
\text { Dispõe sobre a organização } \\
\text { dos serviços de } \\
\text { telecomunicações, a criação e } \\
\text { funcionamento de um órgão } \\
\text { regulador. } \\
\text { Art. } 2^{\circ} \mathrm{O} \text { Poder Público tem o }\end{array}$} & Governo & \multirow[b]{2}{*}{$\begin{array}{l}\text { Regulador } \\
\text { Art. 19, inc. III - Elaborar e propor ao Presidente } \\
\text { República medidas do plano geral de metas } \\
\text { Art. } 79 \text { - Regular as obrigações de universalização } \\
\text { atribuídas às prestadoras de serviço. } \\
\text { Art. 80 - Elaborar plano específico a ser aprovado } \\
\text { pelo poder executivo sobre as metas periódicas de } \\
\text { universalização. }\end{array}$} \\
\hline $\begin{array}{l}\frac{5}{\sigma} \\
\frac{a}{2} \\
\frac{\pi}{0} \\
0 \\
0\end{array}$ & 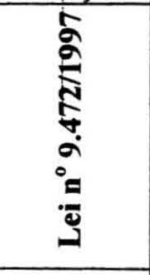 & & $\begin{array}{l}\text { Art. 18, inc. III - Por meio de decreto aprovar o } \\
\text { plano geral de metas para a progressiva } \\
\text { universalização. }\end{array}$ & \\
\hline 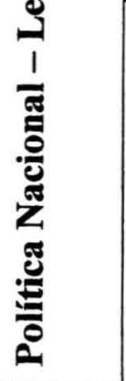 & 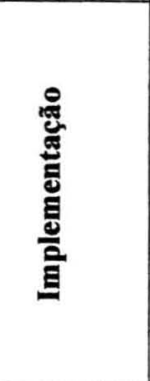 & $\begin{array}{l}\text { dever de: } \\
\text { Inc. I - garantir, a toda a } \\
\text { população, o acesso às } \\
\text { telecomunicações, a tarifas e } \\
\text { preços razoáveis, em } \\
\text { condições adequadas; } \\
\text { Inc. II - estimular a expansão } \\
\text { do uso de redes e serviços de } \\
\text { telecomunicações. }\end{array}$ & $\begin{array}{l}\text { Dec. 2.592/1998 - Aprova o Plano Geral de Metas } \\
\text { para a Universalização do Serviço Telefônico Fixo } \\
\text { Comutado Prestado no Regime Público. } \\
\text { Dec. 4.769/2003 - Aprova o Plano Geral de Metas } \\
\text { para a Universalização do Serviço Telefônico Fixo } \\
\text { Comutado Prestado no Regime Público - PGMU. } \\
\text { Dec. 6.039/2007 - Aprova o Plano de Metas para a } \\
\text { Universalização do STFC em Instituições de } \\
\text { Assistência às Pessoas com Deficiência Auditiva. }\end{array}$ & $\begin{array}{l}\text { Res. 80/2001 - Regulamento para declaração de } \\
\text { cumprimento de obrigações de universalização do } \\
\text { Serviço Telefônico Fixo Comutado }\end{array}$ \\
\hline 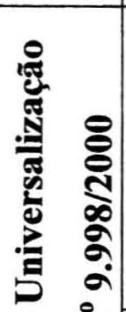 & 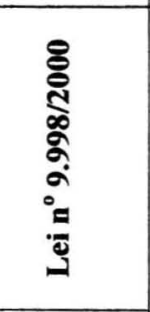 & $\begin{array}{l}\text { Lei } \mathbf{n}^{0} \mathbf{9 . 9 9 8 / 2 0 0 0} \\
\text { Institui o Fundo de } \\
\text { Universalização dos Serviços } \\
\text { de Telecomunicações. } \\
\text { Art. } \mathbf{1}^{\circ} \text { - Fica instituído o } \\
\text { Fundo de Universalização dos } \\
\text { Serviços de } \\
\text { Telecomunicações - FUST, }\end{array}$ & $\begin{array}{l}\text { Art. } 2 \text { - Formular as políticas, as diretrizes gerais e } \\
\text { as prioridades que orientarão as aplicações do } \\
\text { FUST, bem como definir os programas, projetos e } \\
\text { atividades financiados com recursos do Fundo. }\end{array}$ & $\begin{array}{l}\text { Art. } 4^{\circ} \text {, inc. I - implementar, acompanhar e } \\
\text { fiscalizar os programas, projetos e atividades que } \\
\text { aplicarem recursos do FUST; } \\
\text { Inc. II - elaborar e submeter, anualmente, ao } \\
\text { Ministério das Comunicações a proposta } \\
\text { orçamentária do FUST; } \\
\text { Inc. III - prestar contas da execução orçamentária e } \\
\text { financeira do FUST. }\end{array}$ \\
\hline 气 & 章 & $\begin{array}{l}\text { tendo por finalidade cobrir a } \\
\text { parcela de custo atribuível às } \\
\text { obrigações de universalização. }\end{array}$ & $\begin{array}{l}\text { Dec. 3.624/2000 - Dispõe sobre a regulamentação } \\
\text { do Fundo de Universalização dos Serviços de } \\
\text { Telecomunicações - FUST. }\end{array}$ & $\begin{array}{l}\text { Res. 247/2000 - Regulamento para arrecadação da } \\
\text { contribuição das prestadoras de serviços. } \\
\text { Res. 269/2001 - Regulamento de operacionalização } \\
\text { da aplicação de recursos do FUST. }\end{array}$ \\
\hline
\end{tabular}

Fonte: BRASIL, 1997b; BRASIL, 2000. 
Como observado, no Quadro 4 são mostradas as políticas de universalização do setor de telefonia. A política de Estado para universalização deste setor, representada pelas Leis $n^{\text {os }} 9.472 / 1997$ e $9.998 / 2000$, é taxativa ao estabelecer a garantia a toda população ao acesso aos serviços de telecomunicações como dever do poder público (Lei $\mathrm{n}^{\circ} 9.472 / 1997$, art. $2^{\circ}$, inc. I), tendo como instrumento de viabilização o fundo de universalização (Lei $n^{\circ}$ 9.998/2000). Estas leis também definem quais os papéis do governo e do regulador.

Ao governo, cabe definir as metas para a progressiva universalização (Lei $\mathrm{n}^{\circ} 9.472 / 1997$, art. 18 , inc. III), realizada por meio de decreto como o de $\mathrm{n}^{\circ}$ 2.592/1998, o qual compõe o conjunto de políticas governamentais.

Para o regulador, a lei define como função a elaboração e proposição de plano geral de metas ao Presidente da República (art. 19, inc. III) e a regulação das obrigações de universalização atribuídas às prestadoras de serviço (art. 79), mediante desenvolvimento de procedimentos regulatórios e de normatização, que se constituem nos instrumentos da política regulatória.

Quanto ao fundo de universalização, o governo tem o papel de formular políticas e diretrizes gerais para utilização dos recursos do fundo (Lei ${ }^{\circ}$ 9.998/2000, art. $2^{\circ}$ ), como parte das políticas governamentais, cabendo ao regulador a implantação, fiscalização e regulamentação da aplicação dos recursos (art. $4^{\circ}$ ).

Observa-se claramente no Quadro 4 que todas as atribuições estão definidas, cabendo as políticas de Estado e governamentais a fixação das metas sociais, restando ao regulador $\mathrm{e}$ às suas políticas assegurar o cumprimento destas metas. A definição dos papéis do governo e do regulador garante maior estabilidade institucional ao setor, e conseqüentemente, contribui para maiores investimentos na infra-estrutura, conforme demonstrado pelo ritmo de expansão da cobertura de telefonia exposto na Figura 6. 


\subsubsection{Regulação - Eficiência e Equidade}

Como atividade inerentemente estatal, voltada ao interesse público, as políticas de Estado, entre as quais, as regulatórias, devem promover não só a eficiência, mas também a equidade, traduzida como a universalização do acesso aos serviços públicos regulados pelo Estado. Efetivamente, a regulação objetiva a correção das falhas de mercado, ora em termos de eficiência, ora em termos de equidade, ou como resposta para ambas as situações (REYNOLDS, 1981).

Esses objetivos têm sido alvo de muita controvérsia na discussão da regulação. A teoria neoclássica pressupõe que a regulação não deve interferir na redistribuição de bens e serviços, pois há conflito entre eficiência alocativa e universalização dos serviços. Na prática, este conflito ocorre quando da provisão de serviços públicos à população de baixa renda, para os quais os usuários não têm capacidade de pagamento das tarifas (MOITA, 2003), mas cuja prestação deve ser universalizada por razões sociais, éticas e de saúde pública, com vistas à garantia da dignidade da pessoa humana. Na realidade, o caráter público da regulação está associado ao princípio da universalidade do acesso, independente da capacidade de pagamento e da localização dos usuários, cuja determinação deve ser expressa pelo poder concedente no âmbito do contrato de concessão (SILVA, 2004).

Entretanto, BURNS et al. (1995) discordam que a regulação possa ser utilizada com objetivos redistributivos, pois ela é mais custosa, menos eficiente, efetiva e visível do que os instrumentos de transferência de renda e de taxas governamentais. Além disso, segundo estes autores argumentam, os reguladores não dispõem de legitimidade e de expertise para atuação em questões sociais. Deste modo, caso o marco regulatório incorpore objetivos de eficiência alocativa e de equidade, é preciso haver transparência dos compromissos firmados (Id. Ibid.).

Conforme defende BAKKER (2001), no arcabouço neoclássico, a maximização do bem-estar social e a equidade econômica, não social, ocorrem quando há alocação eficiente dos recursos, representada pela igualdade entre preço $\mathrm{e}$ custo marginal. De acordo com esta visão, os conceitos de justiça e de ética estão 
relacionados ao pagamento pelos serviços prestados (REYNOLDS, 1981), colocando-se os usuários na condição de meros consumidores.

Como contraponto à visão neoclássica, BAKKER (2001) afirma que não há conflito entre eficiência e equidade e que as políticas para os serviços de água podem promover simultaneamente sustentabilidade econômica e equidade. Neste contexto, o marco regulatório deve compreender balanço de metas de eficiência e de equidade aceitável pelos membros da sociedade e ter capacidade para ajustar-se às mudanças nos ambientes social, político e ambiental (REYNOLDS, 1981).

Este autor é taxativo ao afirmar que o mercado não possui mecanismos para alcançar metas de equidade ou resolver conflitos inerentes às definições destas metas pelos vários segmentos da sociedade. Outro aspecto refere-se à incapacidade do mercado de lidar com situações onde há impactos não-econômicos de difícil valoração por medidas monetárias (Id. Ibid.; TREBING, 1987). Além disso, os modelos regulatórios neoclássicos tendem a fortalecer o status quo (TREBING, 1987), o que implica a falta instrumentos efetivos que privilegiem o acesso dos mais pobres aos serviços públicos.

Como exemplo, o dilema entre eficiência e equidade pode estar falsamente representado na discussão sobre interesses e conflitos de usuários e não usuários dos serviços. Usuários são aqueles conectados aos sistemas formais de infra-estrutura que pagam tarifas pela fruição destes serviços. Já os não usuários encontram-se desconectados dos sistemas formais por falta de capacidade de pagamento, por não haver infra-estrutura disponível ou por estarem conectados a sistemas próprios ou alternativos.

Segundo MARQUES NETO (2005), aos usuários, denominados por este autor de consumidores efetivos, interessa a qualidade da prestação dos serviços e a modicidade das tarifas, enquanto aos não usuários, chamados de consumidores potenciais, interessa o acesso a estes serviços. Assim, quando a expansão das redes físicas depende do financiamento por recursos próprios, as tarifas podem exceder as expectativas dos consumidores efetivos, o que pode gerar conflito de interesses com os consumidores potenciais (Id. Ibid.). Neste contexto, a regulação assume função relevante de mediar conflitos entre usuários e não usuários e hierarquizar estes objetivos regulatórios, aparentemente conflitantes. 
Há também outros mecanismos baseados no poder discricionário dos reguladores e naqueles especificados no marco regulatório que propiciam margens de atuação aos reguladores para promoção de maior equidade no acesso aos serviços. São exemplos as definições da estrutura de preços das tarifas e de metas de eficiência e compartilhamento destes resultados com os usuários, e a aplicação de penalidades pelo não cumprimento das metas, entre outros. Entretanto, para se atingir estes objetivos, as agências reguladoras precisam deter conhecimento, poderes e suporte político para o exercício destas funções (TREBING, 1981).

No Brasil, a regulação, desde a sua origem, está assentada nos postulados do Código das Águas, e teve na universalidade do acesso aos serviços de infraestrutura de energia e de água um de seus princípios básicos a serem atingidos com a regulação dos serviços públicos (SILVA, 2006).

Nesta pesquisa, entende-se que a regulação deve perseguir objetivos de eficiência e de equidade, embora urge reconhecer a existência de limites nesta atuação. Ademais, as políticas e metas redistributivas são fixadas por atores políticos que possuem legitimidade via processo eleitoral. Não obstante estas ressalvas, o papel dos reguladores é fundamental no processo de universalização dos serviços públicos de infra-estrutura.

\subsubsection{Formas de Regulação}

As empresas monopolistas de serviços públicos apresentam dois tipos de regulação: estrutural e de condutas. A regulação estrutural aborda as condições de entrada e de saída das firmas nos setores regulados e as medidas para separação vertical ${ }^{20}$ de segmentos da prestação dos serviços (PINHEIRO e SADDI, 2005). Já a de condutas regula o comportamento das empresas dentro do mercado e engloba preços, qualidade e investimentos (JOURAVLEV, 2001b). Há também a regulação social, mais relacionada à intervenção do Estado para a correção de externalidades.

\footnotetext{
${ }^{20} \mathrm{Na}$ separação vertical, o processo de produção de bens e serviços, antes realizado por uma só empresa, é segmentado em várias etapas, o que permite a atuação de várias empresas nas diferentes fases da cadeia produtiva (JOURAVLEV, 2001a).
} 
Como cada setor da infra-estrutura apresenta estágios diferentes de desenvolvimento tecnológico e características específicas quanto ao nível de competição em alguns segmentos da prestação dos serviços, os papéis da regulação estrutural e de condutas assumem configurações variadas para cada setor.

Por exemplo, na energia, a cadeia produtiva é dividida em geração, transmissão e distribuição. Esta condição de desverticalização da atividade permite que na geração várias empresas, inclusive com diferentes matrizes energéticas, concorram para ofertar energia aos distribuidores. Assim, nesta área, assume papel relevante a regulação estrutural que define as condições de participação das firmas no mercado de produção de energia. No entanto, o segmento final deste setor, a distribuição, é monopólio natural, onde a regulação de condutas é necessária para simular competição e corrigir falhas de mercado.

Ao mesmo tempo, no saneamento básico, as características do setor não permitem competição, seja pela inviabilidade econômica da desverticalização da prestação dos serviços, seja pela falta de mudanças no padrão tecnológico. Há também outros fatores a dificultar a desagregação do saneamento básico, como a geração de economias de escopo em função da verticalização do setor e a dificuldade de tarifação das diversas etapas da produção (JOURAVLEV, 2004). Assim, por ser atividade típica de monopólio natural, a regulação de condutas é mais relevante que a estrutural (JOURAVLEV, 2001a). Além disso, como não há concorrentes, os reguladores não possuem parâmetros de comparação com outras empresas, e, assim, dificulta-se a fixação de níveis de desempenho para a empresa monopolista (SAPPINGTON, 1994). A Figura 10 apresenta de forma esquemática as configurações dos setores de energia e saneamento básico e as possibilidades de competição em cada área. 
Figura 10 - Configurações dos setores de energia e saneamento básico.

ENERGIA

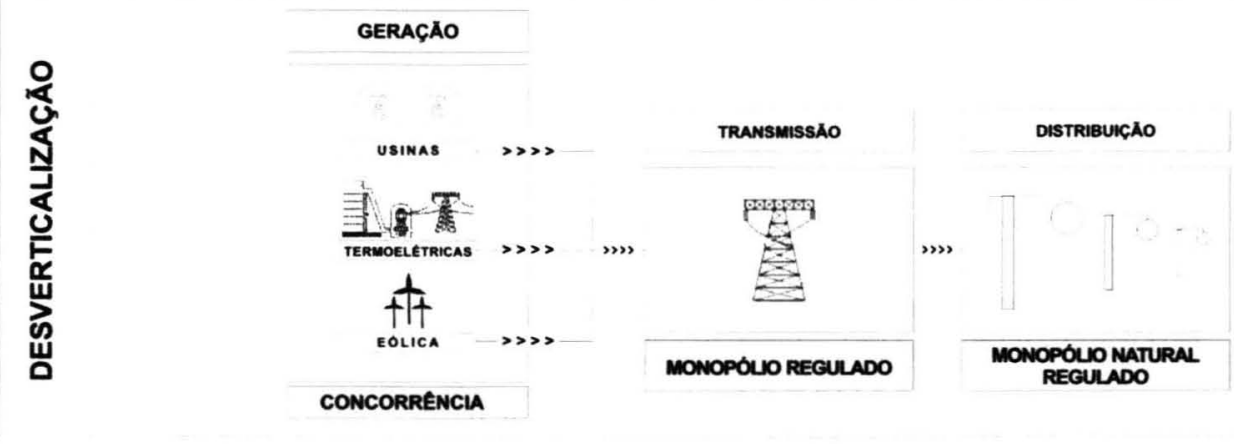

\section{SANEAMENTO BÁSICO}

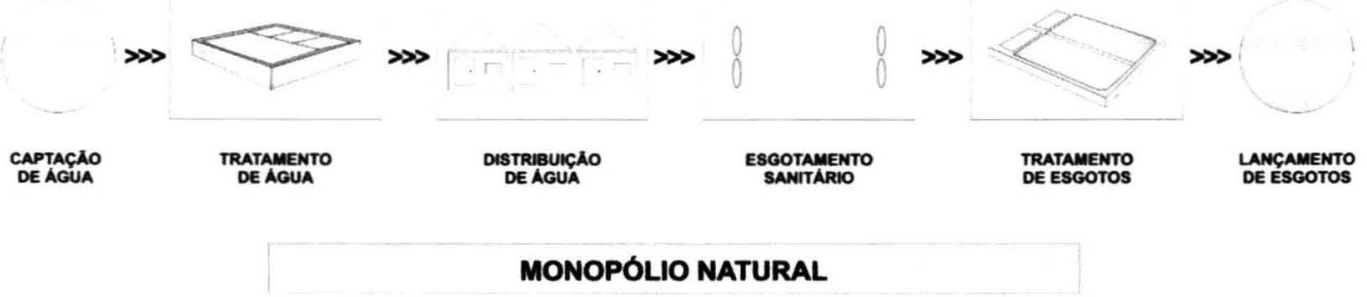

Fonte: Elaboração do autor.

Apesar de o saneamento básico apresentar limitações à competição em decorrência de suas características físicas e econômicas (JOURAVLEV, 2001b), o regulador setorial inglês (OFWAT) definiu como uma de suas prioridades a introdução de competição apenas para grandes consumidores (OFWAT, 2007). Isto se dará mediante o estabelecimento de mecanismos de estímulo à concorrência como separação contábil, permitindo aos potenciais entrantes a observação dos custos das principais atividades desagregadas do setor, além da permissão da competição em serviços de esgotos sanitários e provisão de água bruta, entre outros (Id. Ibid.).

Já para o setor de telecomunicações, a tecnologia é o vetor que viabiliza a competição das empresas para operação dos serviços. Neste caso, a concorrência originou-se da dinâmica da evolução tecnológica e impõe participação efetiva da regulação estrutural nas condições de acesso das empresas ao mercado.

De acordo com JOURAVLEV (2003), a diferença entre o saneamento básico e os setores de telecomunicações e energia, é que a regulação deve se estender 
a todos os segmentos da prestação dos serviços, em virtude da dificuldade de competição nestes segmentos.

Quanto à regulação de condutas, a fixação de preços é a mais relevante, pois interfere diretamente nas condições econômico-financeiras dos serviços regulados. No Quadro 5, constam as características dos principais métodos de regulação de preços, taxa de retorno e teto de preços.

Quadro 5-Características dos principais métodos de regulação de preços.

\begin{tabular}{|c|c|c|}
\hline Características & Taxa de Retorno (rate of return) & Teto de Preço (price cap) \\
\hline Cálculo & $\begin{array}{l}\text { Onde, } \\
R=\mathrm{O}+\mathrm{xA} \\
\mathrm{R} \text { : receitas requeridas } \\
\mathrm{O} \text { : custos operacionais e de depreciação } \\
\text { A: base de ativos a ser remunerada } \\
\mathrm{x} \text { : taxa de retorno } \\
\mathrm{O} \text { valor total das tarifas cobradas deve } \\
\text { ser igual a " } \mathrm{R} \text { ". }\end{array}$ & $\begin{array}{l}\mathrm{P}=\mathrm{RPI} \text { - X } \\
\text { Onde, } \\
\mathrm{P}: \text { preço } \\
\text { RPI: índice de preços no varejo } \\
\mathrm{X} \text { : fator de produtividade }\end{array}$ \\
\hline Procedimento & $\begin{array}{l}\text { 1. empresa apresenta custos } \\
\text { (operacionais e de depreciação) e base } \\
\text { de ativos a ser remunerada; } \\
\text { 2. regulador avalia/revisa custos ("O") } \\
\text { e valor de ativos ("A"), e define taxa de } \\
\text { remuneração ("x"). Os custos aceitos } \\
\text { pelo regulador e a remuneração dos } \\
\text { ativos compõem as receitas requeridas; } \\
\text { 3. define-se o nível de preços que cubra } \\
\text { as receitas requeridas a um lucro zero. }\end{array}$ & $\begin{array}{l}\text { 1. regulador fixa limite máximo de } \\
\text { preços de um bem ou serviço ou de um } \\
\text { conjunto destes; } \\
\text { 2. ao longo do intervalo regulatório, os } \\
\text { preços são reajustados pelo índice de } \\
\text { inflação e reduzidos por um fator de } \\
\text { produtividade; } \\
\text { 3. ao final do período regulatório, é } \\
\text { fixado novo limite com os ganhos de } \\
\text { eficiência distribuídos entre prestador e } \\
\text { usuários. }\end{array}$ \\
\hline Base dos custos & $\begin{array}{l}\text { Histórica (ex-ante), ajustada mediante } \\
\text { inflação projetada. }\end{array}$ & $\begin{array}{l}\text { Prospectiva (ex-post) fundamentada na } \\
\text { operação de uma empresa eficiente. }\end{array}$ \\
\hline $\begin{array}{l}\text { Intervalo } \\
\text { regulatório }\end{array}$ & $\begin{array}{l}\text { Breve e endógeno, ou seja, depende da } \\
\text { conduta da empresa no periodo. }\end{array}$ & $\begin{array}{l}\text { Prolongado e exógeno, suficiente para } \\
\text { que a empresa promova redução de } \\
\text { custos e inovações na produção. }\end{array}$ \\
\hline $\begin{array}{l}\text { Grau de } \\
\text { intervenção } \\
\text { regulatória }\end{array}$ & $\begin{array}{l}\text { Acompanhamento contínuo do } \\
\text { desempenho operacional. }\end{array}$ & $\begin{array}{l}\text { Controle no recebimento do serviço, } \\
\text { com base em um conjunto de parâmetros } \\
\text { de qualidade. }\end{array}$ \\
\hline $\begin{array}{c}\text { Grau de } \\
\text { liberdade da } \\
\text { empresa }\end{array}$ & $\begin{array}{l}\text { Pequeno, pois alterações de preços } \\
\text { necessitam de aprovação do regulador. }\end{array}$ & $\begin{array}{l}\text { Grande, pois o regulador fixa um teto de } \\
\text { preços, podendo a empresa cobrar tarifas } \\
\text { inferiores a este. }\end{array}$ \\
\hline Origem & Estados Unidos & Inglaterra \\
\hline Desvantagens & $\begin{array}{l}\text { - sobreinvestimento, pois o aumento } \\
\text { dos lucros é função da ampliação da } \\
\text { base de ativos; } \\
\text { - incentivos fracos para ganhos de } \\
\text { eficiência e melhorias tecnológicas; } \\
\text { - assimetria de informações dificulta a } \\
\text { correta identificação dos custos } \\
\text { incorridos na prestação dos serviços. }\end{array}$ & $\begin{array}{l}\text { - pode gerar subinvestimento; } \\
\text { - outorga lucros excessivos às empresas; } \\
\text { - há redução na qualidade dos serviços } \\
\text { prestados com o objetivo de diminuir } \\
\text { custos e aumentar lucros. }\end{array}$ \\
\hline
\end{tabular}

Fonte dos dados: FARINA et al., 1997; JOURAVLEV, 2001b; MOITA, 2000; PHILLIPS, 1993; PINHEIRO e SADDI, 2005; SILVA, 2004; VISCUSI et al., 2005. 
Conforme observado neste quadro, independente do método adotado para regulação de preços, as atividades necessárias para determinação de custos e valoração de ativos são complexas e exigem elevada expertise dos reguladores.

No Brasil, o principal mecanismo de precificação utilizado é o da taxa de retorno ${ }^{21}$, adotado desde a edição do Decreto $n^{\circ} 24.643$, de 10 de julho de 1934 , que instituiu o Código das Águas (BRASIL, 1934). Quanto à política de preços, segundo preconiza o art. 180 do referido decreto, as tarifas seriam fixadas trienalmente de acordo com os seguintes critérios:

I - sob a forma do serviço pelo custo, levando-se em conta:

a) todas as despesas e operações, impostos e taxas de qualquer natureza, lançados sobre a empresa, excluídas as taxas de benefício;

b) as reservas para depreciação;

c) a remuneração do capital da empresa.

II - Tendo em consideração, no avaliar a propriedade, o custo histórico, isto é, o capital efetivamente gasto, menos a depreciação;

III - conferindo justa remuneração a esse capital;

IV - vedando estabelecer distinção entre consumidores, dentro da mesma classificação e nas mesmas condições de utilização do serviço;

$\mathrm{V}$ - tendo em conta as despesas de custeio fixadas, anualmente, de modo semelhante.

De acordo com SILVA (2002), o modelo de precificação determinado pelo Código das Águas vigorou por quase sessenta anos na maioria dos setores da infraestrutura sendo considerado instrumento fundamental para a determinação do padrão de regulação nacional ao longo deste período ${ }^{22}$. Atualmente não existe metodologia tarifária clara para os serviços públicos no país e, de forma geral, apesar da prevalência da taxa de retorno, já são observadas aplicações dos mecanismos do tipo teto de preços (ARAÚJO e PIRES, 2000).

Já a regulação da qualidade tem como objetivo fixar condições e parâmetros para a qualidade dos produtos e serviços prestados, e, também, verificar o cumprimento destas disposições. Especificamente em relação aos setores da infraestrutura, o Quadro 6 identifica alguns aspectos da qualidade importantes para a

\footnotetext{
${ }^{21}$ No Código das Águas, o método da taxa de retorno era denominado de "serviço pelo custo".

${ }^{22}$ Durante o PLANASA, o método da taxa de retorno foi legalmente disciplinado pela Lei ${ }^{\circ} 6.528$, de 11 de maio de 1978, tendo sido revogado pela Lei ${ }^{\circ} 11.445 / 2007$.
} 
regulação dos serviços públicos de infra-estrutura. Afora os parâmetros técnicos, a regulação da qualidade controla aspectos de difícil verificação e quantificação, como a cortesia no atendimento aos usuários (SAPPINGTON, 2005).

Quadro 6 - Regulação da qualidade de serviços públicos de infra-estrutura.

\begin{tabular}{|c|c|}
\hline Infra-Estrutura & Exemplos de Parâmetros Regulados \\
\hline a Elétrica & $\begin{array}{l}\text { - Duração Equivalente de Interrupção por Unidade Consumidora; } \\
\text { - Duração de Interrupção Individual por Unidade Consumidora ou por Ponto } \\
\text { de Conexão; } \\
\text { - Duração Máxima de Interrupção Contínua por Unidade Consumidora ou por } \\
\text { Ponto de Conexão. }\end{array}$ \\
\hline Gás Canalizado & $\begin{array}{l}\text { - Poder Calorífico Superior; } \\
\text { - Composição de gases (metano, etano, propano, butano, inertes (N2+ CO2) } \\
\text { nitrogênio, oxigênio, gás sulfídrico); } \\
\text { - Ponto de orvalho de água, } 1 \text { atm (1). }\end{array}$ \\
\hline $\begin{array}{c}\text { Saneamento } \\
\text { Básico }\end{array}$ & $\begin{array}{l}\text { - Pressão dinâmica disponível na rede de distribuição; } \\
\text { - Pressão estática máxima na rede de distribuição; } \\
\text { - Parâmetros físico-químicos (cor, turbidez, pH, metais, etc.) e } \\
\text { bacteriológicos da água distribuída. }\end{array}$ \\
\hline Telecomunicações & $\begin{array}{l}\text { - Quantidade de reparos de Telefone de Uso Público / } 100 \text { TUPs; } \\
\text { - Chamadas originadas no Centro de Atendimento da prestadora no Período } \\
\text { de Maior Movimento; } \\
\text { - Solicitações de reparo, por cem acessos em serviço por mês; } \\
\text { - Tempo de atendimento das solicitações de reparo. }\end{array}$ \\
\hline $\begin{array}{c}\text { Transportes de } \\
\text { Passageiros }\end{array}$ & $\begin{array}{l}\text { - Quantidades de viagens programadas, constantes do cadastro da delegação e } \\
\text { viagens realizadas; } \\
\text { - Idade média da frota em operação e idade máxima de operação; } \\
\text { - Número de acidentes verificado. }\end{array}$ \\
\hline
\end{tabular}

Fonte: ANATEL, 2003; ANEEL, 2000; ANTT, 2005; ANP, 2002; ARCE, 2001.

Conforme observado neste quadro, a regulação da qualidade exige mecanismos diretos e indiretos para acompanhamento dos parâmetros e indicadores regulados, que demandam recursos humanos e custos elevados. Além disso, o exercício desta regulação pode ocasionar conflitos ou sobreposição de tarefas com outros reguladores setoriais ${ }^{23}$.

VISCUSI et al. (2005) justificam que a pouca utilização da regulação da qualidade é devida ao seu alto custo. Efetivamente, a medida mais relevante para reduzir custos e efetuar acompanhamento mais direto da prestação dos serviços é a participação dos usuários no controle da qualidade dos serviços e produtos.

\footnotetext{
${ }^{23}$ Estes aspectos serão discutidos mais detalhadamente nas seções seguintes.
} 
De acordo com JOURAVLEV (2001b), as regulações de preços e de qualidade são interdependentes, pois uma redução da qualidade equivale a um aumento de preços. Em corroboração à importância da regulação da qualidade, HOLT (2005) advoga que sem esta regulação as metodologias de precificação podem fornecer incentivos distorcidos para investimentos e para melhoria da qualidade dos serviços. Entretanto, esta abordagem não tem sido compreendida pelos reguladores, provavelmente em decorrência da complexidade da análise da regulação da qualidade com métodos de regulação de preços.

Na regulação social, destaca-se o controle público das atividades que não são objeto de intervenção direta dos mercados como vigilância sanitária, padrões ambientais e de segurança (VARGAS, 2005), além de falhas de mercado que afetam interesses difusos dos usuários (REICH, 2006). Neste tipo de regulação, o caráter de intervenção do Estado está mais relacionado à ação fiscalizadora do que propriamente à regulação de mercados ou à promoção da concorrência (PACHECO, 2007). De modo geral, a atuação da regulação social ocorre principalmente sobre as externalidades ambientais de caráter negativo causadas pela diluição de efluentes líquidos nos corpos aquosos, lançamento de poluentes na atmosfera e despejo de resíduos sólidos em locais inadequados.

As principais formas de regulação são os contratos, leilão de concessão e agência reguladora. As características mais relevantes e as desvantagens de cada formato são apresentadas no Quadro 7. 
Quadro 7 - Principais características e desvantagens das formas de regulação.

\begin{tabular}{|c|c|c|}
\hline Forma & Características & Desvantagens \\
\hline Por Contratos & $\begin{array}{l}\text { - Propriedade dos ativos permanece } \\
\text { com o Estado; } \\
\text { - Compromissos com investimentos e } \\
\text { critérios de revisão de tarifas são } \\
\text { fixados no contrato. }\end{array}$ & $\begin{array}{l}\text { - Não existe obrigatoriedade de } \\
\text { entidade administrativa do Estado para } \\
\text { acompanhamento do contrato; } \\
\text { - Há pouca flexibilidade para alteração } \\
\text { do contrato durante o período de } \\
\text { vigência. }\end{array}$ \\
\hline $\begin{array}{c}\text { Leilão de } \\
\text { Concessão } \\
\text { (Competição de } \\
\text { Demsetz)* }\end{array}$ & $\begin{array}{l}\text { - Leilão pelo direito ao monopólio em } \\
\text { função do preço mais baixo da tarifa } \\
\text { e/ou maior valor de outorga. }\end{array}$ & $\begin{array}{l}\text { - Se o contrato for de curto prazo, há } \\
\text { pouco incentivo para manutenção das } \\
\text { instalações e para realização dos } \\
\text { inv̀estimentos; } \\
\text { - Se o contrato for de longo prazo, } \\
\text { menor será o efeito das condições } \\
\text { estabelecidas na licitação inicial; } \\
\text { - Há possibilidade de conluio entre os } \\
\text { licitantes. }\end{array}$ \\
\hline $\begin{array}{c}\text { Agência } \\
\text { Reguladora }\end{array}$ & $\begin{array}{l}\text { - Propriedade dos ativos pode ser } \\
\text { estatal ou do operador privado (caso } \\
\text { britânico); } \\
\text { - Presença de agência independente e } \\
\text { autônoma para regulação da } \\
\text { concessão. }\end{array}$ & $\begin{array}{l}\text { - Captura da entidade reguladora pelas } \\
\text { empresas reguladas; } \\
\text { - Restrição da independência do ente } \\
\text { regulador pelo poder executivo; } \\
\text { - Baixa articulação entre os } \\
\text { reguladores setoriais. }\end{array}$ \\
\hline
\end{tabular}

Fonte: JOURAVLEV, 2004; MAJONE, 1996; PHILIPPS, 1993; SILVA, 2004.

Nota: *Proposta original feita por Harold Demsetz, no artigo intitulado Why regulate utilities, publicado no Journal of Law and Economics, vol. 11, $\mathrm{n}^{\circ} 1$, abril de 1968.

Para os serviços públicos de infra-estrutura, o formato de regulação depende da análise, entre outras, das seguintes variáveis: falhas de mercado a serem corrigidas, características do mercado regulado, ambiente político-institucional, propriedade dos ativos, titularidade dos serviços e capacidade administrativa do Estado para regular os serviços. Cada uma destas variáveis apresenta possibilidades múltiplas o que torna a definição do formato uma tarefa complexa. A Figura 11 apresenta matriz com as principais variáveis e subvariáveis determinantes para a escolha da forma de regulação da prestação de serviços públicos de infra-estrutura. 
Figura 11 - Principais variáveis para definição da forma de regulação dos serviços públicos de infra-estrutura.

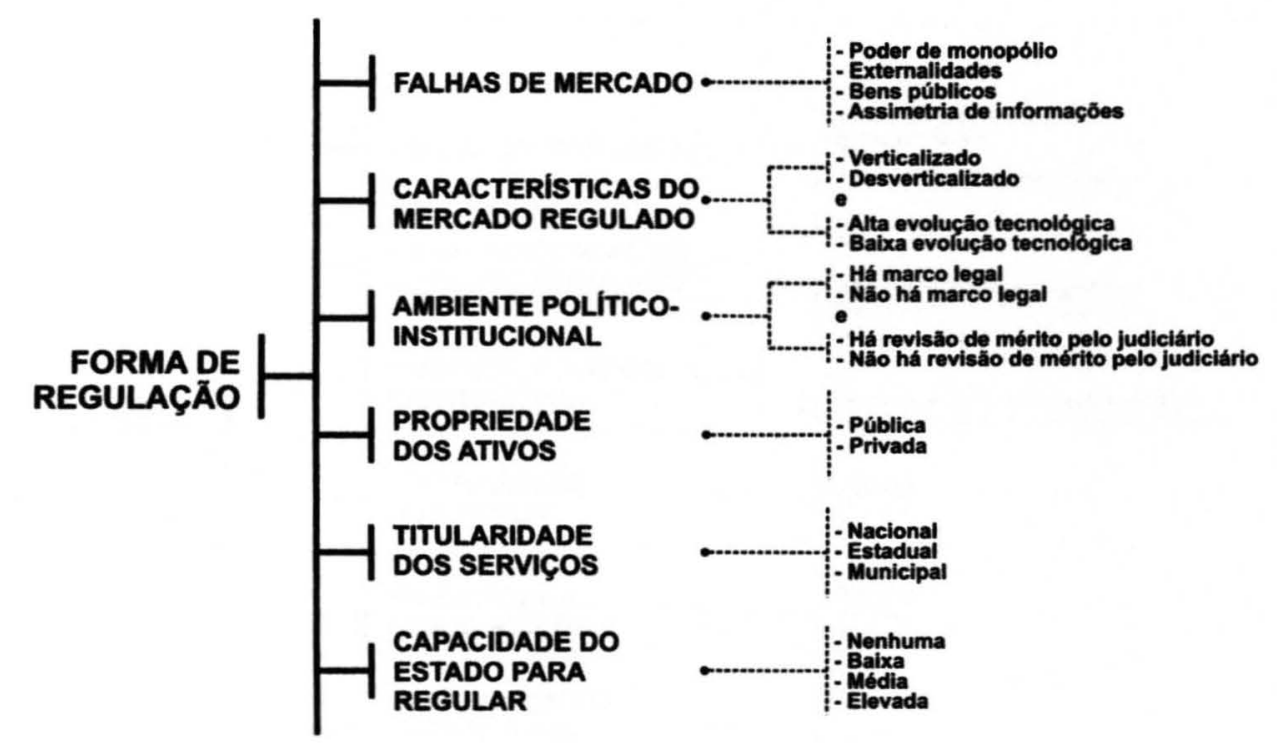

Fonte: Elaboração do autor.

Conforme a análise conjunta do Quadro 7 e da Figura 11 permite concluir, para cada setor da infra-estrutura existe um nível de intervenção regulatório variado. Por exemplo, nas Figuras 12A e 12B são apresentadas duas situações distintas de áreas da infra-estrutura nacional, onde em cada caso é indicada uma forma de regulação específica. Na primeira situação, Figura 12A, têm-se as principais variáveis que determinam a forma de regulação dos serviços de telecomunicações. Neste setor, sobretudo em decorrência das características da titularidade dos serviços, da capacidade do Estado para regular e da existência do marco regulatório, o melhor formato de regulação é por agências. Apesar da vantagem do acompanhamento permanente da prestação destes serviços por agência reguladora, os custos de operação e manutenção deste ente são elevados. 
Figura 12A - Principais variáveis para definição da forma de regulação no setor de telecomunicações.

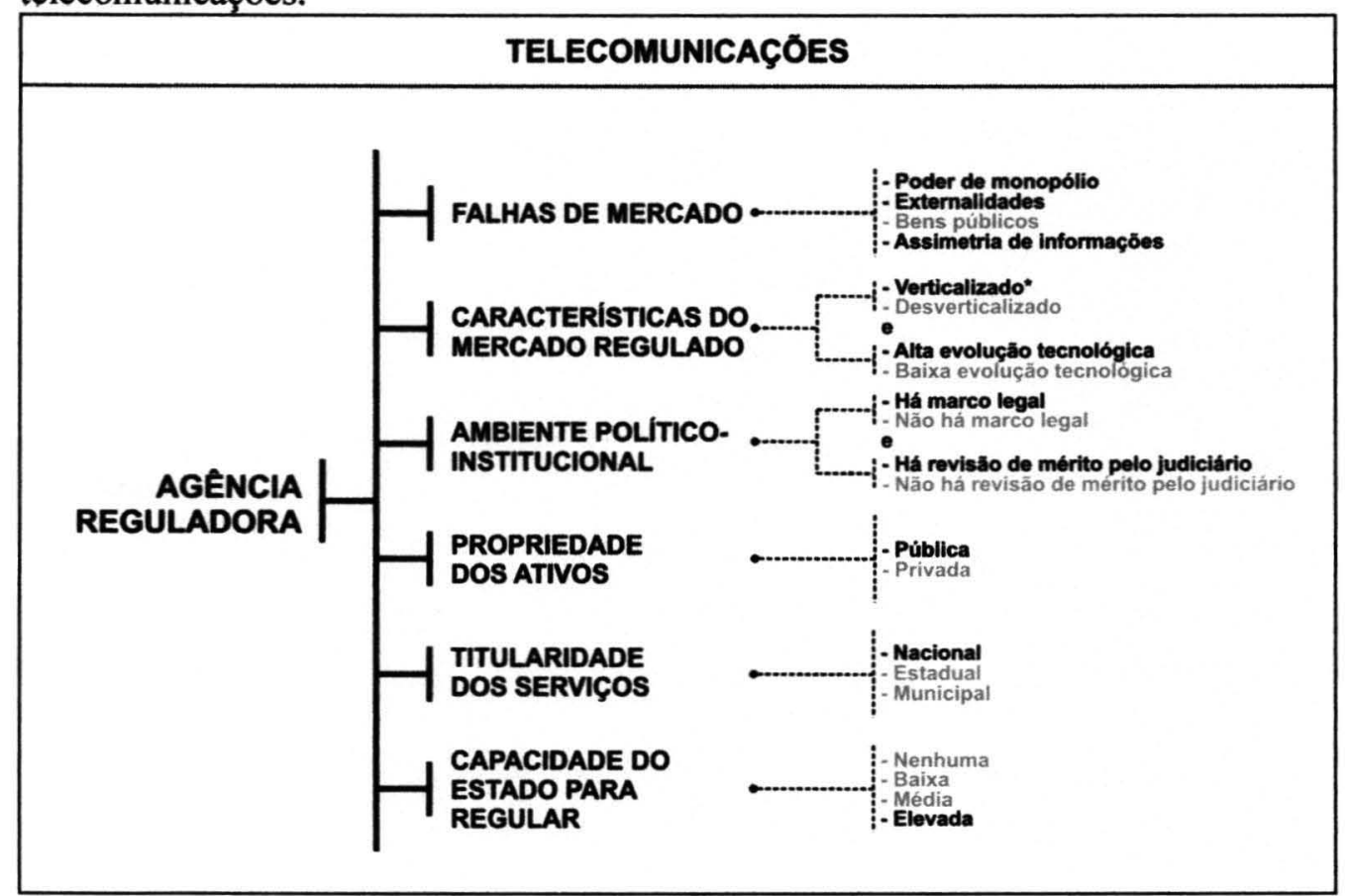

Fonte: Elaboração do autor.

Nota: *Verticalizado na maioria dos segmentos.

Já no contexto do saneamento básico, mostrado na Figura 12B, onde as falhas de mercado são mais evidentes, notadamente as externalidades e o poder de monopólio, a titularidade é fragmentada, e há falta de capacidade dos entes federados para regular os serviços, a regulação por contratos é provavelmente o melhor formato. Estes contratos, geralmente de longo prazo, devem conter cláusulas explícitas sobre revisão de tarifas, direitos dos usuários, metas e investimentos, e penalidades em caso de descumprimento do contrato (PIRES e PICCININI, 1999). Desta forma, mesmo sem uma entidade reguladora, a presença de garantias legais permite que o titular dos serviços argúa junto ao judiciário o cumprimento das obrigações contratuais. Entretanto, as desvantagens deste formato estão relacionadas à falta de acompanhamento contínuo das metas e obrigações contratuais, à rigidez contratual e à dependência do judiciário para solução de conflitos, o que pode retardar investimentos e a solução de problemas. 
Figura 12B - Principais variáveis para definição da forma de regulação no setor de saneamento básico.

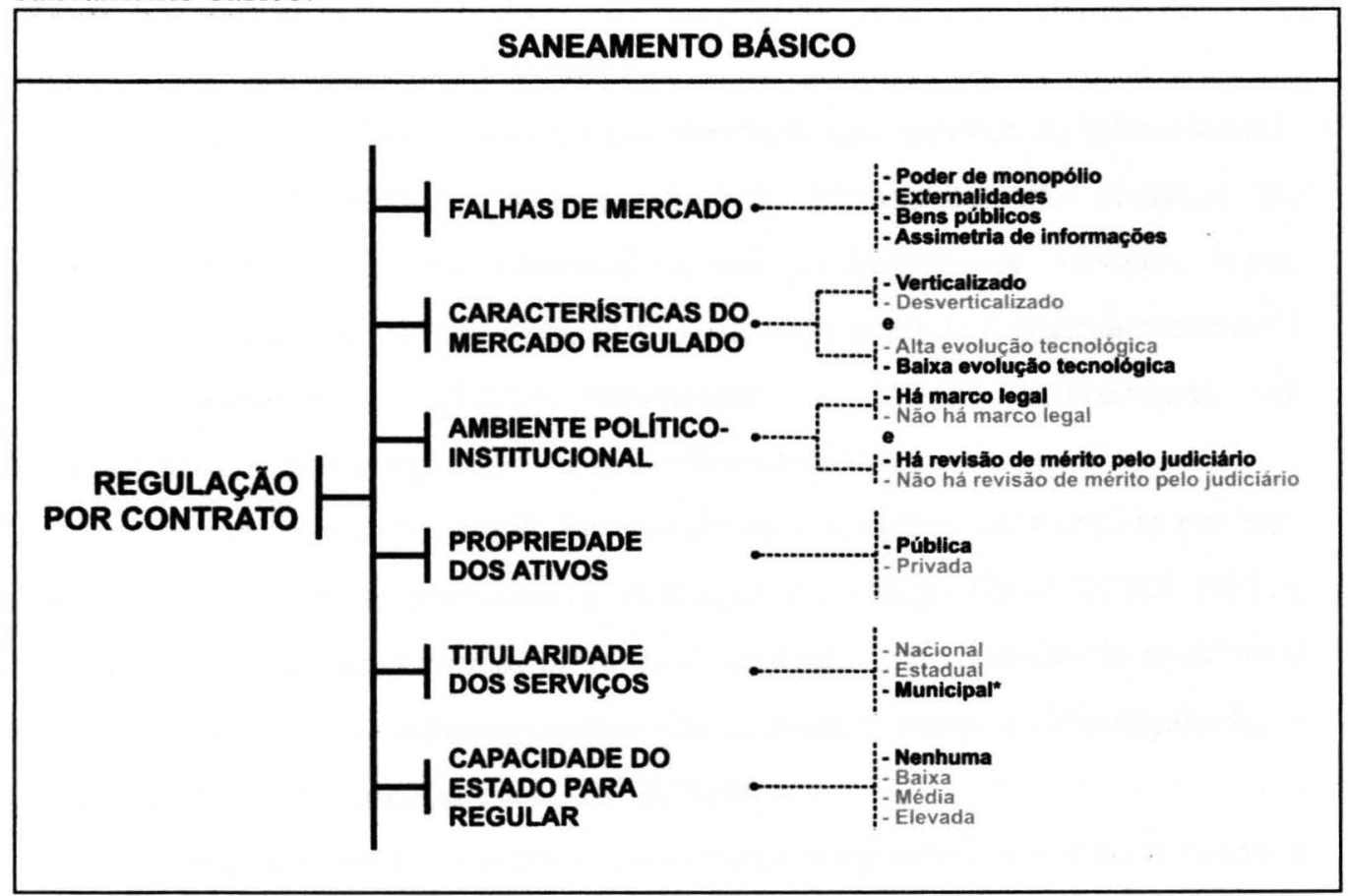

Fonte: Elaboração do autor.

Nota: *Considera-se para efeito desta discussão a titularidade como municipal. Deve-se ressaltar que esta decisão encontra-se sob objeto de discussão no Supremo Tribunal Federal.

Dentro da regulação por agências, há ainda vários arranjos institucionais, como a formação de consórcios entre estados e municípios, ou entre municípios para regulação dos serviços, ou a delegação desta atividade a agência reguladora de outro ente federado. Estas alternativas podem viabilizar a regulação em virtude da economicidade que a agregação de várias concessões proporciona à função reguladora.

Além disso, os modelos apresentados não são rígidos e admitem combinações entre diferentes formas de regulação, a exemplo de contrato com presença de agência reguladora. Neste caso específico, o papel da agência seria monitorar o desempenho da empresa conforme cláusulas contratuais, mediar e resolver disputas no âmbito do contrato e disciplinar aspectos não abordados no contrato de concessão (GROOM et al., 2006). Este arranjo institucional para regulação teria a vantagem de diminuir a interferência política ao oferecer maior tecnicidade para o acompanhamento do contrato (MENDES et al., 2006). Assim, 
estas alternativas permitem que, mesmo sem capacidade para regular, titulares dos serviços compartilhem ou deleguem a regulação a outros entes públicos, proporcionando efetividade a esta atividade.

Ademais, o caráter monopolista da prestação dos serviços de infra-estrutura e suas complexidades reforçam a necessidade do acompanhamento contínuo das condutas técnicas e econômico-financeiras dos prestadores de serviços, sejam públicos ou privados, no sentido de garantir o interesse público. Conseqüentemente é preciso compreender as agências reguladoras, o desenho institucional, seu funcionamento e o marco regulatório a que estão submetidas.

Efetivamente, só há regulação quando esta atividade for exercida por ente público, pois se trata de prerrogativa exclusiva do Estado (MARQUES NETO, 2005). No entanto, algumas formas privadas de controle sobre a atividade econômica exercem interferência no comportamento das empresas, como a auto-regulação, o mercado de capitais e a transparência das informações.

$\mathrm{Na}$ auto-regulação, a própria governança corporativa controla a empresa (TUROLLA e OHIRA, 2006), impondo riscos de que os ganhos de eficiência obtidos pela empresa sejam usufruídos pela corporação na forma de altos salários e excesso do quadro de pessoal. No controle pelo mercado de capitais, os acionistas podem se apropriar dos ganhos de eficiência (Id. Ibid.). Neste caso haverá incentivos para aumento excessivo dos lucros em detrimento da modicidade tarifária.

Já transparência de informações da prestação dos serviços é um mecanismo informal de controle, à medida que os indicadores de desempenho de diversas empresas de um setor regulado são publicados, permitindo à sociedade avaliar tarifas, ineficiências e custos da empresa concessionária mediante comparação com indicadores de outras firmas. Desta forma, haverá incentivo para a empresa ser mais eficiente que a média do setor. Exemplo deste formato pode ser encontrado no Sistema Nacional de Informações sobre Saneamento do Ministério das Cidades, no qual empresas do setor, estaduais e municipais, públicas e privadas, são comparadas entre si em termos de eficiência técnica e econômico-financeira. Entretanto, este sistema depende da auto-adesão dos prestadores de serviço e inexistem mecanismos que obriguem o repasse de informações ou punam as empresas em caso de envio de 
dados incorretos. Estas formas de controle privado enfatizam que a regulação pública é na verdade o principal instrumento para se garantir o interesse público.

\subsection{AGÊNCIAS REGULADORAS}

\subsubsection{Desenho Regulatório}

Conforme discutido na teoria da regulação, subseção 3.2.2, o desenho regulatório é considerado instrumento basilar para se garantir eficiência e eficácia à atividade reguladora. Entre os principais mecanismos do desenho regulatório, destacam-se a independência da agência, os mandatos de seus dirigentes e a participação social (CONFORTO, 2000). Além disso, o ente regulador necessita ter capacidade técnica (MARQUES NETO, 2005), bem como as decisões da agência devem ser tomadas por órgãos colegiados (FARINA et al., 1997). Conseqüentemente, o conjunto destes mecanismos possibilita minimizar riscos de captura das agências, desvios de finalidade e corrupção. A seguir são discutidos alguns destes mecanismos.

\subsubsection{Independência da agência}

As agências reguladoras devem no seu exercício manter independência em relação aos atores envolvidos no processo regulatório: governo, concessionárias e usuários. Contudo, a eqüidistância do regulador quanto a estes atores deve considerar a capacidade de articulação e de pressão de cada ator, pois na relação concessionáriousuário, a capacidade do primeiro é inúmeras vezes superior à do usuário (CONFORTO, 2000). Com o objetivo de promover o equilíbrio entre as partes, a agência deve incentivar e criar instrumentos que minimizem a hipossuficiência dos usuários diante das empresas monopolistas. 
Em face das características da maioria dos serviços de infra-estrutura, altamente dependentes de capital intensivo, e das fragilidades do ambiente políticoinstitucional, a independência das agências é vista por vários autores como instrumento para minimização de riscos regulatórios e de atração de investidores privados (CORREA, 2006; FARINA et al., 1997; PACHECO, 2007; PIRES e GOLDSTEIN, 2001). Não obstante o modelo regulatório blindar a agência das ingerências políticas, este deixa lacunas para interferência dos agentes privados regulados (SILVA, 2002).

Ao se referir às agências reguladoras, MARQUES NETO (2005) descreve a existência de dois tipos de independência, orgânica e administrativa, consideradas pelo autor como mutuamente dependentes. A independência orgânica contempla mecanismos que delimitam os espaços entre o órgão regulador e o poder executivo, como a estabilidade dos dirigentes e a ausência de controle hierárquico (Id. Ibid.). Já na independência administrativa estão presentes os instrumentos necessários para se garantir a efetividade dos resultados da agência como autonomia de gestão e de suas finanças, liberdade para organização dos serviços e regime de pessoal adequado (Id. Ibid.).

No âmbito da independência administrativa, OLIVEIRA et al. (2005) enfatizam a importância da independência financeira para se evitar a completa subordinação ao chefe do executivo bem como para assegurar concretude à atuação da agência. Para ocorer a independência financeira, é necessário que os recursos das agências sejam originados, entre outros, da cobrança de taxas de fiscalização (PIRES e PICCININI, 1999; MARQUES NETO, 2005). Apesar de estes recursos serem pagos às agências reguladoras diretamente pelas empresas concessionárias, são na verdade originados dos próprios usuários, já que as taxas são componentes das tarifas dos serviços públicos regulados.

Efetivamente, a independência das agências não significa adoção de atos unilaterais por parte destas entidades, haja vista existir todo um arcabouço de políticas de Estado, de governo e de regulação, e relações entre estas para consecução de cada política setorial, as quais devem ser seguidas por cada ente no âmbito de sua competência. Ademais, cabe ao executivo indicar os dirigentes das agências, o que lhe confere garantia minima quanto ao cumprimento das políticas 
regulatórias, além de estabelecer, em determinadas situações, contratos de gestão com as agências reguladoras (OLIVEIRA et al., 2005).

Os requisitos relacionados à independência das agências demonstram que esta característica é dificil de ser alcançada. Notadamente há grande desequilíbrio entre os atores no processo regulatório. Pelo lado do governo, existe toda uma cultura política de centralidade das decisões no âmbito do chefe do poder executivo, assim como a operacionalização administrativa das agências depende da liberação de recursos próprios armanezados no caixa único do governo. Já as concessionárias, sejam de caráter público ou privado, desempenham importante papel no desenvolvimento econômico no âmbito do titular dos serviços, e possuem capacidade econômica e política para interferir de forma direta e indireta no processo regulatório.

Por último estão os usuários, parcela mais frágil do equilíbrio entre os atores, que, a depender do capital social acumulado, necessitam dos instrumentos postos à sua disposição pelo ente regulador para inserir-se de forma mais ativa na regulação. Assim, a independência regulatória, apesar de determinada por lei, é comparável a um jogo, altamente dinâmico, onde cada ator disputa continuamente espaços, cria estratégias e move suas peças para obtenção de vantagens dentro do processo regulatório.

Desta forma, SUNDFELD (2002) advoga a utilização do termo autonomia por considerar que independência é na verdade utilizada como desejo de autonomia ante o poder executivo. Entretanto, como ressalta SEROA DA MOTTA (2006), a autonomia deve estar diretamente relacionada aos mecanismos de transparência de decisões e de prestação de contas à sociedade ${ }^{24}$.

\subsubsection{Mandatos dos dirigentes}

O estabelecimento de mandatos atenua a influência de pressões de caráter político sobre a agência e contribui para que os objetivos da instituição,

\footnotetext{
${ }^{24}$ Também denominado de accountability.
} 
fundamentados em lei, sejam perseguidos pelos dirigentes (OLIVEIRA et al., 2005). Além disso, a limitação do prazo do mandato evita que os dirigentes criem vínculos com grupos de interesse no processo regulatório (FARINA et al., 1997).

Outros aspectos inerentes aos mandatos são a estabilidade e a nãocoincidência, e os critérios de escolha dos dirigentes. A estabilidade permite serem tomadas decisões de natureza regulatória de acordo com critérios técnicos e legais, inclusive quando estas deliberações são discordantes do governo em exercício (PIRES e PICCININI, 1999). Na não-coincidência dos mandatos, as escolhas para o quadro dirigente ocorrem de forma escalonada, de maneira que durante a gestão de determinado governo somente parcela da diretoria da agência é indicada ou renovada, já que a parcela restante, escolhida durante o governo anterior, permanece na agência até o final do seu mandato. Assim, caso haja mudança de orientação no comando do governo, há menos possibilidades de ruptura da política regulatória. Desta forma, o mecanismo da não-coincidência dos mandatos confere maior estabilidade à agência e às próprias políticas regulatórias.

Quanto aos critérios de seleção dos dirigentes, os escolhidos devem possuir notória capacidade técnica, necessária para condução das políticas e discussões regulatórias, caracterizadas por apresentarem elevada complexidade. Ademais, a seleção dos dirigentes via indicação do executivo e aprovação pelo legislativo contribui para a legitimação da independência da agência (MARQUES NETO, 2005). Conseqüentemente, o envolvimento do poder legislativo permite se compartilhar a responsabilidade política da escolha entre os dois poderes e torna transparente o processo de seleção dos candidatos.

\subsubsection{Participação e controle social}

Por si só, a existência de agência reguladora não garante os efeitos benéficos da regulação. Como afirma CONFORTO (2000), a eficácia e a transparência desta atividade são diretamente proporcionais ao controle social exercido. Além de auxiliar e complementar a regulação, o controle social pode até substituir em certas ocasiões 
a influência do ente regulador sobre as empresas reguladas (BORENSTEIN, 2000). Neste contexto, entende-se como participação e controle social a tomada de decisões e de opiniões pela sociedade sobre rumos e diretrizes da prestação dos serviços públicos, por intermédio de audiências e consultas públicas, ouvidorias, conselhos setoriais e de usuários.

As audiências públicas têm por objetivo o debate e a apresentação oral de assunto de interesse relevante enquanto a consulta pública destina-se a colher opiniões e sugestões sobre documentos ou minutas de resoluções de interesse público (ANATEL, 2001). Para MENDES et al. (2007), as audiências e consultas públicas são instrumentos de construção coletiva das demandas sociais e a participação social nos processos de concessão e regulação tornam mais efetiva a gestão dos serviços públicos.

Já a ouvidoria é o canal de entrada e de maior contato das agências com os usuários dos serviços públicos regulados. Mediante telefone gratuito e atendimento de balcão das agências, os usuários denunciam, reclamam, sugerem e elogiam acerca da prestação dos serviços. Deste modo, as ouvidorias se constituem em possibilidade concreta de exercício da cidadania (DANTAS, 2007).

Em relação aos conselhos setoriais, estes podem ser de caráter consultivo ou deliberativo. Nos de caráter consultivo os usuários recomendam ações e opinam sobre decisões regulatórias, enquanto nos deliberativos as decisões da agência são submetidas à aprovação do conselho. Em relação aos conselhos consultivos, GALVÃO JUNIOR e XIMENES (2007) advogam que a falta de poder decisório destes conselhos pode resultar em seu enfraquecimento. Assim, para o controle social ser efetivo, é importante que os atores envolvidos no processo decisório estejam informados e capacitados acerca do objeto da decisão, condições estas indispensáveis à participação qualificada e à democratização do processo (PEREIRA e JOHNSSON, 2005). Contudo, nos conselhos deliberativos, a depender dos critérios de funcionamento e de composição, corre-se o risco de que as decisões sejam baseadas em critérios políticos.

Como exemplo, TUROLLA (2007) discute os riscos na definição de reajustes e revisões de tarifas do setor de saneamento por meio de conselhos. Isto, segundo o autor, poderia privilegiar grupos sociais específicos em detrimento da sociedade. 
Além dos mecanismos de participação social citados, JOURAVLEV (2003) defende o envolvimento dos usuários como fonte de consulta sobre suas demandas em relação aos serviços prestados e sobre a qualidade destes serviços. Entretanto, limitar a participação dos usuários como fonte de informação possibilita se devolver aos usuários, principalmente aos mais pobres, a responsabilidade do controle sobre a prestação dos serviços (REICH, 2006). Portanto, no controle social da prestação dos serviços, o papel do regulador deve ser pró-ativo a fim de incentivar e promover efetivamente este controle (MARQUES NETO, 2005).

\subsubsection{Decisão colegiada}

A principal justificativa para as agências reguladoras serem dirigidas por órgãos colegiados é a minimização dos riscos de captura (CONFORTO, 1998; OLIVEIRA et al., 2005). Ademais, a decisão colegiada contribui para maior diversidade de pensamentos e estabilidade quando da ocorrência de mudanças no ambiente político externo (MARQUES NETO, 2005; JOURAVLEV, 2001b; FOSTER, 2005), não obstante haver também desvantagens em relação ao aumento no tempo para tomada de decisões e maior custo administrativo (FARINA et al., 1997).

Então, a questão é definir qual o número ideal de dirigentes para o colegiado, mas sem comprometer a celeridade das decisões e sem elevar o custo regulatório. Esta decisão deve também estar relacionada ao tamanho da agência, à quantidade de serviços regulados e ao orçamento da instituição. Segundo cálculos de TUROLLA (2007), sete seria o número ideal de diretores de uma agência reguladora, considerando duas variáveis no estudo: celeridade das decisões e independência. Por outro lado, agências reguladoras comandadas por um único dirigente apresentam maiores possibilidades de gestão personalista e risco de captura por setores regulados (CONFORTO, 1998).

Aliada à decisão colegiada, a transparência das decisões é essencial para se garantir a legitimidade social das agências (ARAÚJO e PIRES, 2000). Daí ser 
necessário divulgar previamente as pautas das reuniões, tornar públicas as reuniões colegiadas e disponibilizar na internet os resultados e a fundamentação das decisões do órgão colegiado da agência.

\subsubsection{Tecnicidade e quadro de pessoal}

A expertise técnica é necessária para que decisões no âmbito administrativo apresentem legitimidade (OLIVEIRA et al., 2005; PIRES e PICCININI, 1999). É essa legitimidade que associada à independência diferencia as agências reguladoras do modelo burocrático tradicional (MAJONE, 2006).

Para tanto, o quadro técnico da agência reguladora deve ser composto por profissionais contratados mediante concurso público, remunerados com salários compatíveis ou no mínimo equivalentes aos do mercado regulado (CONFORTO, 1998; PIRES e GOLDSTEIN, 2001; SALGADO, 2003). Outra característica do quadro de pessoal é a necessidade de permanente capacitação, pois os reguladores devem estar preparados para compreender a constante evolução do ambiente regulado que lida com mudanças tecnológicas, qualidade de produtos e serviços, metodologias tarifárias, entre outros (CORREA, 2006; SAPPINGTON, 1994).

$\mathrm{Na}$ verdade, o conhecimento acumulado do quadro técnico é essencial para compensar as desvantagens existentes entre a agência e as empresas reguladas, no que se refere ao domínio das informações sobre a prestação dos serviços como custos e qualidade, reduzindo assim a assimetria de informações existente entre regulador e regulado.

Se por um lado o conhecimento técnico fornece aos reguladores mais poder e discricionariedade do que outros agentes administrativos (MAJONE, 2006), por outro não pode ser usado como instrumento de exclusão da população das decisões que lhe afetam (SERRA, 2004). Assim, a expertise não pode ser insulada na própria agência e deve ser compartilhada com outros reguladores setoriais e sociais. Além disso, o conhecimento técnico precisa ser traduzido em linguagem de fácil compreensão para comunicação à sociedade. 


\subsubsection{Marco Regulatório e Agências}

Os mecanismos do desenho regulatório devem estar dispostos em um conjunto de leis, decretos, normas, regulamentos e contratos, denominado marco regulatório. Em outras palavras, o marco regulatório compreende as regras do jogo, tanto para o poder concedente, mediante a definição dos limites institucionais para atuação no setor regulado e das políticas públicas setoriais, como para as concessionárias, com critérios de avaliação de tarifas e normas de qualidade dos serviços, e também para os usuários dos serviços, por meio da fixação de direitos e deveres sobre a prestação dos serviços regulados.

A depender do tipo de instrumento legal, o marco regulatório é produzido por várias instituições. Por exemplo, no poder legislativo são elaboradas as leis de políticas públicas e de criação da agência para o setor regulado enquanto no executivo são estabelecidos decretos das políticas setoriais de governo. Às agências, cabe a edição de normas sobre a qualidade da prestação dos serviços bem como a interpretação de cláusulas contratuais. No âmbito do direito privado, concessionárias e poder executivo, ora representado pela agência reguladora, elaboram contratos de concessão para a prestação dos serviços.

Quanto aos contratos, ao mesmo tempo em que precisam detalhar metas de cobertura e de qualidade, devem também permitir flexibilidade com vistas a possibilitar negociação transparente de cláusulas econômico-financeiras, entre outros (CONFORTO, 1998). Na verdade, dificilmente há contratos completos no longo prazo, característica dos setores de infra-estrutura, o que poderá resultar em problemas transacionais entre prestadores de serviço e usuários (FARINA et al., 1997).

Mesmo com o marco regulatório bem elaborado, não haverá eficácia se a agência reguladora não detiver condições e instrumentos adequados para o desempenho de suas funções ou não possuir poderes para este exercício (CORREA, 2006). Para tanto, no exercício das funções regulatórias, as agências são dotadas de poder executivo, para fiscalizar a prestação dos serviços; legislativo, para elaborar resoluções e normas; e judiciário, para arbitrar conflitos entre usuários e 
concessionários e aplicar penalidades (PHILLIPS, 1993; SALGADO, 2003). MARQUES NETO (2005) apresenta outra classificação e sugere a existência de seis poderes para as agências reguladoras: fiscalização, normativo, outorga, sancionatário, conciliação e recomendação. Apesar da nomenclatura proposta por este autor ser diferente, os conteúdos por ele discutidos sobre os poderes de fiscalização e de outorga estão contemplados no escopo do poder executivo, citado anteriormente. Já os poderes sancionatário e de conciliação estão situados no âmbito do poder judiciário enquanto o normativo tem a mesma atribuição do poder legislativo. Como nova contribuição, MARQUES NETO (2005) aponta o poder de recomendação, inerente à prerrogativa da agência subsidiar o governo na formulação de políticas públicas.

A ampla margem de atribuições e poderes outorgados às agências reguladoras tem resultado em inúmeras críticas por vários segmentos da sociedade. Efetivamente, a legitimidade das agências está amparada em quatro aspectos: primeiro, as agências são criadas por lei, mediante discussão e aprovação dos representantes eleitos pela população; segundo, os dirigentes são escolhidos pelo poder executivo, também eleito pela população; terceiro, as decisões da agência são baseadas em normas e procedimentos formais, às vezes, inclusive, com participação social; por último, estas decisões devem ser embasadas e passíveis de questionamento pelo poder judiciário (MAJONE, 2006).

\subsubsection{Agências Reguladoras no Brasil}

A discussão sobre a regulação por agências iniciou-se no país por volta dos anos 1930 quando da elaboração do Código das Águas. Neste período, vários autores, baseados no sistema norte-americano de comissões, destacaram-se na proposição de modelos de regulamentação ${ }^{25}$ para os serviços de utilidade pública. No

\footnotetext{
${ }^{25}$ Apesar de existirem algumas diferenças conceituais, até em decorrência do ambiente políticoinstitucional do período, a regulamentação era equivalente à atual regulação enquanto as comissões exerciam as mesmas funções das modernas agências reguladoras.
} 
contexto destas propostas, a maioria dos serviços públicos eram prestados pela iniciativa privada, pouco regulados e em plena crise (INFURB, 1995).

A regulamentação defendida à época justificava-se pela defesa do interesse público junto às atividades econômicas, cujo exercício seria mais intenso e extenso que o poder de polícia do Estado, abrangendo o estabelecimento de padrões para prestação dos serviços, fixação de lucros, tarifas e métodos contábeis a serem utilizados pelas empresas regulamentadas (MELLO, 1940).

Quanto à forma de regulamentação, PINTO (1941), inspirado na correção das falhas do modelo norte-americano, concebeu novo arcabouço para as comissões no Brasil. Nesta concepção, seria outorgada às comissões a competência jurisdicional, ficando livres de apelação de suas decisões por parte dos tribunais ordinários (Id. Ibid.). Além disso, inicialmente haveria uma única comissão, de caráter autárquico e com abrangência federal, que centralizaria a regulamentação de todos os serviços de utilidade pública no país. Em relação às atuais agências reguladoras, o modelo proposto por PINTO (1941) apresentava algumas semelhanças. Entre estas, existência de mandatos para os dirigentes, autonomia administrativa para a comissão e objetivos idênticos como modicidade tarifária, garantia de serviço adequado e equilíbrio econômico-financeiro dos contratos, denominado então de estabilidade financeira.

Entretanto coube a VALLADÃO (1941) a mais importante defesa da regulamentação dos serviços de utilidade pública, mediante elaboração do anteprojeto do Código das Águas e sua apresentação junto à Comissão Legislativa do Congresso Nacional. VALLADÃo (1941) propôs a criação da Comissão Federal de Forças Hidráulicas, composta por sete comissários, escolhidos pelo Presidente da República e aprovados pelo Congresso, com competência para editar regulamentos, examinar pedidos de concessão, fixar tarifas, fiscalizar a prestação dos serviços, entre outros. A comissão poderia ser descentralizada no âmbito de estados e municípios desde que estes obedecessem as regras estabelecidas pela Comissão Federal. Mas o texto final do Código das Águas aprovado, Decreto ${ }^{\circ}{ }^{24.643 / 1934}$, não considerou as comissões, e atribuiu ao Serviço de Águas do Departamento Nacional de Produção Mineral, subordinado à aprovação prévia do ministro da agricultura, a regulamentação dos serviços. 
Apesar de vários instrumentos regulatórios, como as comissões, não terem sido aprovados no Código das Águas, SILVA (2006) destaca que a principal contribuição de Alfredo Valladão, Anhaia Mello, Bilac Pinto, entre outros, refere-se aos princípios que nortearam a regulação do Código e a legislação subseqüente, como universalidade do acesso e modicidade tarifária.

Mesmo com o intenso debate travado à época, o modelo das comissões não evoluiu devido ao centralismo do Estado Novo, e posteriormente em virtude das políticas desenvolvimentistas dos anos 1950 e 1960 que consolidaram a intervenção direta do Estado para provisão de bens e serviços públicos. Daí, com a propriedade estatal, a regulamentação era “dispensável”. Este modelo de provisão estatal perdurou por quase sessenta anos (INFURB, 1995).

Assim, a criação das agências reguladoras no Brasil ocorreu somente em meados dos anos 1990 no processo de reforma do Estado, no qual setores da infraestrutura tiveram seus controles acionários abertos à participação da iniciativa privada. Neste processo de reforma, a lógica central era a mudança do perfil do Estado brasileiro, de produtor de bens e serviços para regulador de serviços públicos concedidos à iniciativa privada. Este processo ocorreu simultaneamente em vários países da América Latina sob um arcabouço ideológico neo-conservador (SILVA, 2002), incentivado pelas instituições multilaterais como o Banco Mundial e o Fundo Monetário Internacional.

Inicialmente, o debate sobre as agências reguladoras se deu mediante o encaminhamento de suas leis de criação ao Congresso Nacional, para, posteriormente, serem discutidos os conceitos básicos do modelo regulatório (PECI, 2007). Neste contexto, às agências caberiam as funções de organização e manutenção do equilíbrio do setor e do mercado regulado, bem como a resolução de conflitos entre poder concedente, concessionárias e usuários (DI PIETRO, 2004).

A par disso, a falta de discussão na sociedade sobre o papel destas instituições provocou, a princípio, intensa insatisfação da opinião pública, que logo associou os aumentos tarifários dos serviços públicos privatizados à existência dos órgãos reguladores. Ao mesmo tempo, alguns processos de privatização e de montagem de marcos regulatórios se concretizaram antes da existência das agências, o que dificultou a adaptação destes órgãos ao ambiente institucional já estabelecido. 
Segundo PECI (2007) e DI PIETRO (2004), o modelo regulatório nacional foi baseado na experiência norte-americana quanto à forma de implementação, embora aspectos conceituais e procedimentais desta experiência tenham sido desconsiderados no modelo nacional. Na opinião de SALGADO (2003), porém, a transposição de experiências regulatórias dos Estados Unidos e Inglaterra para o Brasil é inviável, pois as realidades dos serviços de infra-estrutura são bastante diferentes, haja vista ainda haver elevado déficit de cobertura nos países em desenvolvimento. Ademais, o ordenamento jurídico inglês pressupõe rígida hierarquia das normas nacionais sobre as subnacionais, inexequível para países de estrutura federativa (SILVA, 2004). Efetivamente, o modelo brasileiro apresenta algumas particularidades que misturam regulação por contratos, originada do modelo francês, com agências reguladoras, tradicionais do modelo anglo-saxão.

Para dotar as agências reguladoras com maior autonomia de atuação, foi outorgado a estes entes o caráter jurídico-administrativo de autarquias especiais. Conforme MARQUES NETO (2005), este caráter, aliado às prerrogativas jurisdicionais, confere às agências atribuições típicas de Estado.

O projeto de reforma de Estado resultou ainda na criação das agências executivas, responsáveis por implementar políticas e diretrizes de governo. São exemplos a Agência Nacional de Águas, a Agência Nacional de Vigilância Sanitária e a Agência Nacional de Saúde Complementar.

A diferença entre agências executiva e reguladora fica evidente quando da análise de suas autonomias. Ambas são dotadas de autonomia administrativa, mas somente as reguladoras possuem autonomia política, condição necessária para regular serviços monopolistas (PACHECO, 2007). Como relata SALGADO (2007), o formato decisório das agências é outra característica que delimita os dois modelos. Segundo esta autora, nas agências executivas prevalece a decisão monocrática, enquanto nas reguladoras a deliberação é colegiada.

Ao todo, são identificadas no país 32 agências reguladoras, sendo seis de âmbito nacional, 21 estaduais e cinco municipais, conforme demonstrado na Figura 13. Destas, $59 \%$ foram criadas na segunda metade da década de 1990 . Tal fato reafirma a incipiência do modelo regulatório nacional por agências, quando comparado ao sistema norte-americano, cuja origem remonta ao final do século XIX. 
Figura 13 - Leis de criação das agências reguladoras brasileiras.

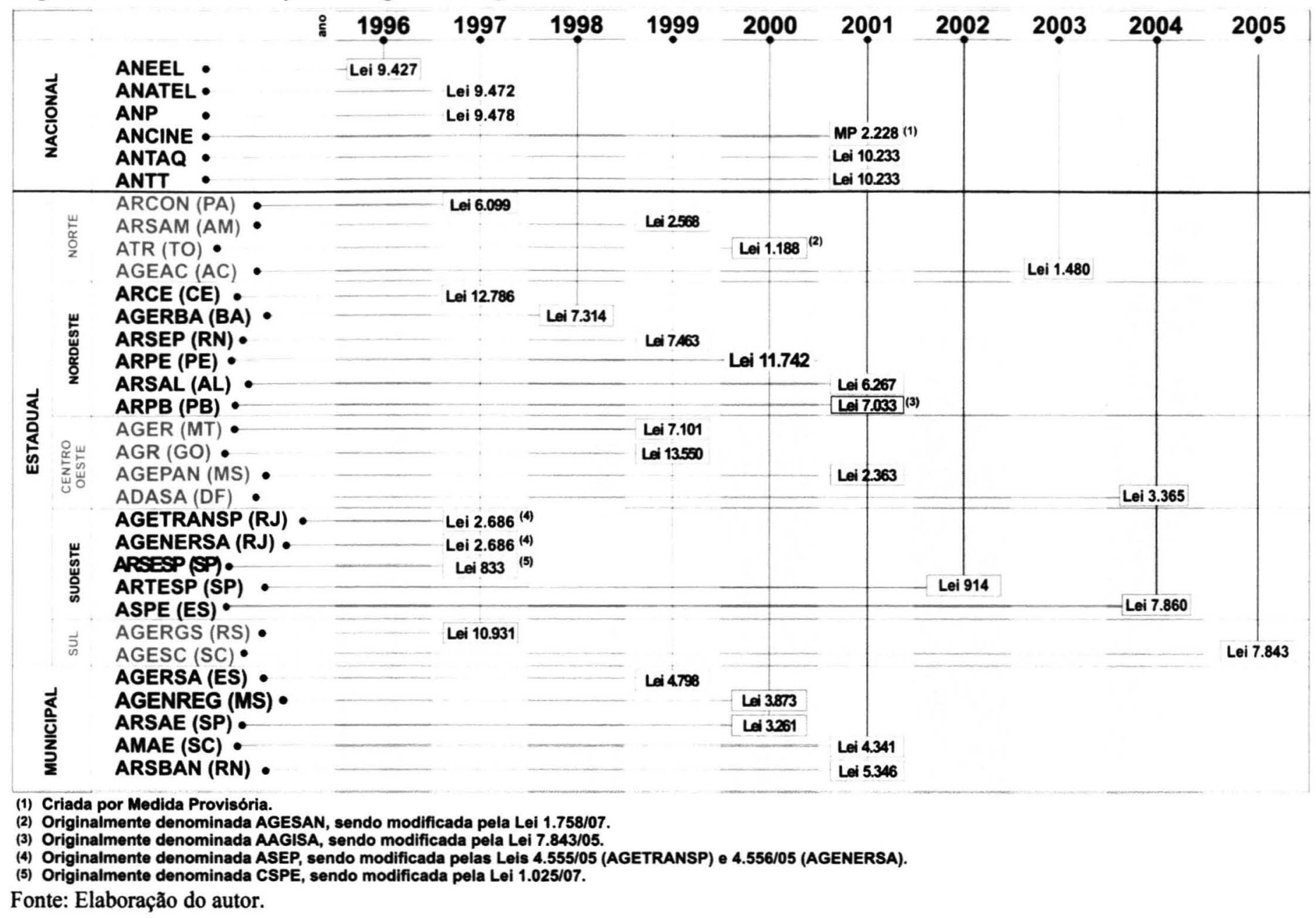


Em relação às áreas de atuação das agências reguladoras, a Figura 14 demonstra que as agências nacionais e municipais atuam de forma geral em um único setor regulado, enquanto as estaduais são multissetoriais.

Figura 14 - Mapa de atuação das agências reguladoras brasileiras.

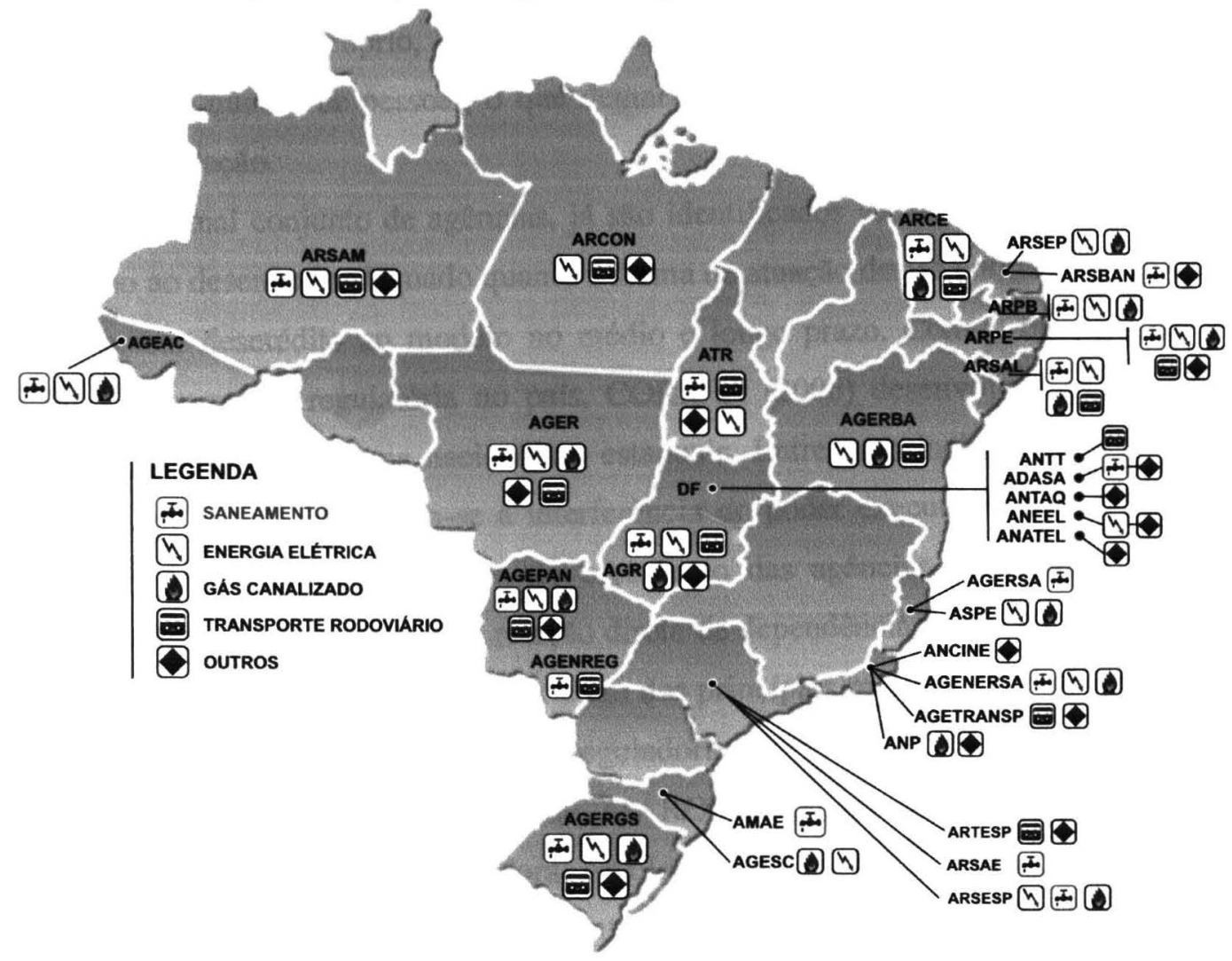

Fonte: Elaboração do autor.

O mapa de atuação mostra não haver regulação por agências em importantes Estados brasileiros como Minas Gerais e Paraná, ou especificamente em relação aos estados da Bahia e São Paulo ${ }^{26}$, quanto a regulação do saneamento básico.

Notadamente, observa-se que as agências municipais atuam mais especificamente no setor de saneamento básico. Com o advento da Lei $\mathrm{n}^{\circ}$ 11.445/2007, que torna obrigatória a regulação dos serviços de saneamento básico

\footnotetext{
${ }^{26}$ A criação da agência estadual para regular os serviços de saneamento básico em São Paulo ocorreu somente no final de 2007.
} 
em sistemas concessionados, espera-se rápido crescimento no número de agências municipais neste setor, principalmente nas capitais e nas grandes cidades.

Apesar de o mapa demonstrar amplo rol de competências de várias agências, nem todas efetivamente atuam na regulação dos serviços. A estruturação de uma agência exige, pois, além da lei de criação, elaboração de marcos setoriais, concurso de pessoal próprio, montagem de instalações físicas, treinamento e capacitação do quadro de pessoal, o que demanda determinado período para início efetivo da regulação.

No atual conjunto de agências, já são identificados vários problemas tanto em relação ao desenho inadequado quanto à forma de atuação destas entidades, o que poderá causar descrédito ao modelo no médio e longo prazo. Com o objetivo de avaliar a governança regulatória no país, CORREA (2006) desenvolveu pesquisa com 21 agências reguladoras nacionais e estaduais. Entre os principais problemas detectados no estudo, destacam-se a interferência do poder executivo nas decisões regulatórias e o contingenciamento do orçamento das agências. A retenção dos recursos próprios das agências cria relação direta de dependência destes entes com o poder executivo. Tal relação compromete um dos princípios basilares da regulação: a independência e autonomia das agências reguladoras.

Em corroboração a este estudo, MARQUES NETO (2005) afirma que a principal ameaça às agências reguladoras está localizada no âmbito da independência administrativa em função do constante contingenciamento dos recursos, políticas de contratação de pessoal e de salários, entre outros. Ainda segundo este autor, a solução para o equacionamento dos problemas das agências seria a adoção de uma lei geral no sentido de melhor caracterizar o conceito de agência reguladora, padronizar o regime jurídico e resolver problemas referentes ao desenho de agências. Esta lei encontra-se em discussão no Congresso Nacional desde 2004, por meio do Projeto de Lei $n^{\circ}$ 3.337. Entretanto ainda não se obteve consenso entre as diferentes visões sobre regulação existentes dentro do parlamento e no próprio governo federal. 


\subsection{REGULAÇÃO DO SETOR DE ÁGUA E ESGOTO}

\subsubsection{Características do Setor de Água e Esgoto}

As características do setor de água e esgoto, sumariadas no Quadro 8, conferem várias dimensões de análise a esta prestação de serviços, além de justificar, de forma inequívoca, a necessidade de regulação setorial. Estas características apresentam importantes repercussões para definição dos arranjos institucionais de gestão e de regulação da prestação dos serviços e, mais especificamente, para delimitar a forma de atuação dos reguladores.

Quadro 8 - Características do setor de saneamento e suas repercussões.

\begin{tabular}{|c|c|c|}
\hline \multicolumn{2}{|r|}{ Características } & Repercussões \\
\hline \multirow{5}{*}{$\frac{\mathscr{0}}{\frac{0}{n}}$} & $\begin{array}{l}\text { Maioria dos ativos (redes } \\
\text { de água e esgoto) } \\
\text { encontra-se enterrada }\end{array}$ & $\begin{array}{l}\text { - Difícil determinação do estado de conservação. } \\
\text { - Custo de manutenção elevado e complexidade para detecção de } \\
\text { vazamentos nas tubulações. }\end{array}$ \\
\hline & $\begin{array}{l}\text { Mudança lenta no padrão } \\
\text { tecnológico }\end{array}$ & $\begin{array}{l}\text { - Poucos ganhos de eficiência mediante avanços tecnológicos. } \\
\text { - Ativos com vida útil prolongada. }\end{array}$ \\
\hline & $\begin{array}{l}\text { Qualidade dos produtos } \\
\text { de complexa verificação } \\
\text { pelo usuário-consumidor }\end{array}$ & $\begin{array}{l}\text { - Necessidade de estrutura adequada para monitoramento da } \\
\text { qualidade de produtos e serviços ofertados pelas concessionárias. }\end{array}$ \\
\hline & $\begin{array}{l}\text { Redes integradas em } \\
\text { aglomerados urbanos }\end{array}$ & $\begin{array}{l}\text { - Envolvimento de mais de um ente federado na gestão dos serviços. } \\
\text { - Expansão da infra-estrutura associada ao planejamento urbano. }\end{array}$ \\
\hline & $\begin{array}{l}\text { Essencialidade no uso e } \\
\text { consumo dos produtos } \\
\text { (água e esgoto) }\end{array}$ & $\begin{array}{l}\text { - Universalidade do atendimento independe da capacidade de } \\
\text { pagamento do usuário. } \\
\text { - Geração de externalidades positivas e negativas para a saúde } \\
\text { pública, meio ambiente, recursos hídricos, entre outros. }\end{array}$ \\
\hline \multirow{6}{*}{ 导 } & Custo fixo elevado & - Pouca flexibilidade para etapalização dos investimentos. \\
\hline & $\begin{array}{l}\text { Ativos específicos e de } \\
\text { longa maturação, e } \\
\text { existência de sunk costs }\end{array}$ & $\begin{array}{l}\text { - Monopólio natural. } \\
\text { - Inexistência de usos alternativos. } \\
\text { - Baixo valor de revenda. } \\
\text { - Possibilidade remota de saída das concessionárias do mercado } \\
\text { (não-contestável). } \\
\text { - Pouca atratividade para investimentos. }\end{array}$ \\
\hline & $\begin{array}{l}\text { Assimetria de } \\
\text { informações }\end{array}$ & $\begin{array}{l}\text { - Demais atores do setor dependem da informação técnica e } \\
\text { econômico-financeira disponibilizada pelas concessionárias. }\end{array}$ \\
\hline & Demanda inelástica & $\begin{array}{l}\text { - Possibilidade de extração de rendas significativas pelo prestador de } \\
\text { serviços (monopólio). }\end{array}$ \\
\hline & Economias de escala & $\begin{array}{l}\text { - Viabilidade da prestação dos serviços por uma única empresa } \\
\text { (monopólio). }\end{array}$ \\
\hline & Economias de escopo & $\begin{array}{l}\text { - Custos comuns na operação de serviços de água e esgoto e } \\
\text { tratamento de esgotos, tornando mais viável a prestação dos serviços } \\
\text { por uma única empresa (monopólio). }\end{array}$ \\
\hline
\end{tabular}

Fonte dos dados: FARINA et al., 1997; JOURAVLEV, 2001b; INFURB, 1995; BRASIL, 1995b; SEROA DA MOTTA e MOREIRA, 2006; TUROLLA e OHIRA, 2006. 
A localização da infra-estrutura de redes dificulta a verificação das condições de manutenção e operação, o que resulta no aumento da carga de fiscalização e de informação para os reguladores (JOURAVLEV, 2001b). Em virtude do caráter essencial dos serviços de saneamento básico, a qualidade de seus produtos assume maior importância que em qualquer outro setor da infra-estrutura de serviços públicos, obrigando o regulador a monitorá-la continuamente.

Devido a assimetria de informações, o regulador tende a focar sua atuação nas condutas mais facilmente observáveis do regulado (JOURAVLEV, 2003), como a qualidade da água distribuída e a pressão disponível na rede, cuja coleta de dados pode ser realizada diretamente pelo regulador. Este comportamento pode restringir a abrangência da atividade regulatória, deixando para segundo plano questões centrais, como verificação de custos e tarifas, sobre as quais os reguladores dependem de informações disponibilizadas pelos prestadores de serviço.

Outra repercussão importante decorre da existência de externalidades, cujos efeitos extrapolam os limites da atuação da regulação setorial e o escopo dos contratos de prestação dos serviços. Assim, as interfaces do setor com as áreas de saúde pública, meio ambiente, recursos hídricos, defesa do consumidor e planejamento urbano, ampliam a complexidade e o volume de informações requeridos para a adequada regulação, e exige articulação intersetorial entre estas áreas.

As características econômicas do setor, relativas ao elevado volume de investimentos e à especificidade dos ativos, podem gerar comportamento oportunista ex-post por parte dos reguladores, como por exemplo mudanças de regras tarifárias após a construção de obras e instalações operacionais (JOURAVLEV, 2001b). Conseqüentemente, este é mais um fator a dificultar o aporte de investimentos para o setor, e obriga que o marco regulatório e o desenho da agência ofereçam garantias e estabilidade de regras suficientemente claras para os investidores.

A universalidade do atendimento, relacionada ao caráter essencial da prestação dos serviços, independe da capacidade de pagamento dos usuários, o que contraria as regras de mercado (INFURB, 1995). Desta forma, o poder de monopólio se contrapõe ao caráter essencial dos serviços e a sua demanda inelástica, tornando a 
regulação fundamental para garantir o equilíbrio entre produtores e consumidores (FARINA et al., 1997).

Assim, desde a sua origem, os serviços de água e esgoto estão associados ao duplo caráter de serviço público voltado para o atendimento às necessidades básicas da população e da atividade econômica, relacionada à produção (SILVA, 2004). Ainda de acordo este autor, este duplo caráter não causou problemas na maioria dos países da América Latina, pois tais objetivos tiveram a mesma importância estratégica.

Segundo a teoria da regulação, as características apresentadas para o setor de saneamento configuram situações de falhas de mercado como poder de monopólio, externalidades, bens públicos e assimetria de informação, o que justificaria a regulação do setor. Além disso, vários estudiosos reafirmam a necessidade de regulação setorial com a seguinte finalidade:

- Assegurar eficiência e eficácia da prestação dos serviços (PEROSA, 2002);

- Gerar incentivos para práticas eficientes de gestão, para expansão do produto e redução de tarifas (SEROA DA MOTTA, 2006);

- Maximizar a qualidade dos serviços e alavancar investimentos com vistas à modernização e à universalização do setor (CONFORTO, 2000);

- Favorecer a adoção de gestão profissional e a autonomia administrativa das empresas públicas, e ampliar a participação privada no setor (PENA e ABICALIL, 1999);

- Limitar a interferência política no setor mediante regras implementadas independente do ciclo eleitoral (TRÉMOLET e HUNT, 2006);

- Garantir a universalização do setor e evitar que os usuários paguem excessivamente pelos serviços prestados (BRITTO, 2001).

Considerando ser o setor de água e esgoto operado majoritariamente por empresas estatais, além da necessidade do atendimento às características do desenho regulatório, conforme discutido nas seções anteriores, a regulação setorial deve enfatizar a divisão de atribuições entre poder concedente e regulador. Esta premissa é vista como a base do sistema regulador (INFURB, 1995). Efetivamente, a regulação é mais complexa quando as duas partes, regulado e regulador, pertencem ao mesmo ente federado. Diante disso, podem acontecer conflitos de interesse, sendo 
necessário, além da garantia de atendimento aos princípios de independência e autonomia, que o desenho regulatório preveja mecanismos de transparência, prestação de contas e controle social, entre outros, sob riscos de inviabilizar o atendimento aos objetivos regulatórios.

\subsubsection{Regulação Suprasetorial}

As características do setor de saneamento, sobretudo as externalidades, provocam rebatimento da regulação setorial nas suas diversas interfaces, notadamente nas áreas de saúde pública, meio ambiente, recursos hídricos e defesa do consumidor. $O$ limite entre estas regulações é tênue, e na ausência de coordenação intersetorial e atuação concorrente, pode haver problemas de sobreposição de funções, com incremento de custos e ineficácia das diversas atividades regulatórias.

As principais interfaces destas áreas com a regulação dos serviços de água e esgoto, especificamente para cada etapa da cadeia produtiva do setor, são mostradas nas Figuras 15 a 17. Apesar de existir relação entre a área de meio ambiente e a etapa produtiva de abastecimento de água, assim como recursos hídricos e esgotamento e tratamento de esgotos, procurou-se apresentar nestas figuras apenas as interfaces mais relevantes.

$\mathrm{Na}$ Figura 15 constam as principais interfaces da prestação dos serviços de abastecimento de água com a regulação intersetorial, com destaque para as áreas de saúde pública e de recursos hídricos. 
Figura 15 - Interfaces da regulação da prestação dos serviços de abastecimento de água com a regulação intersetorial.

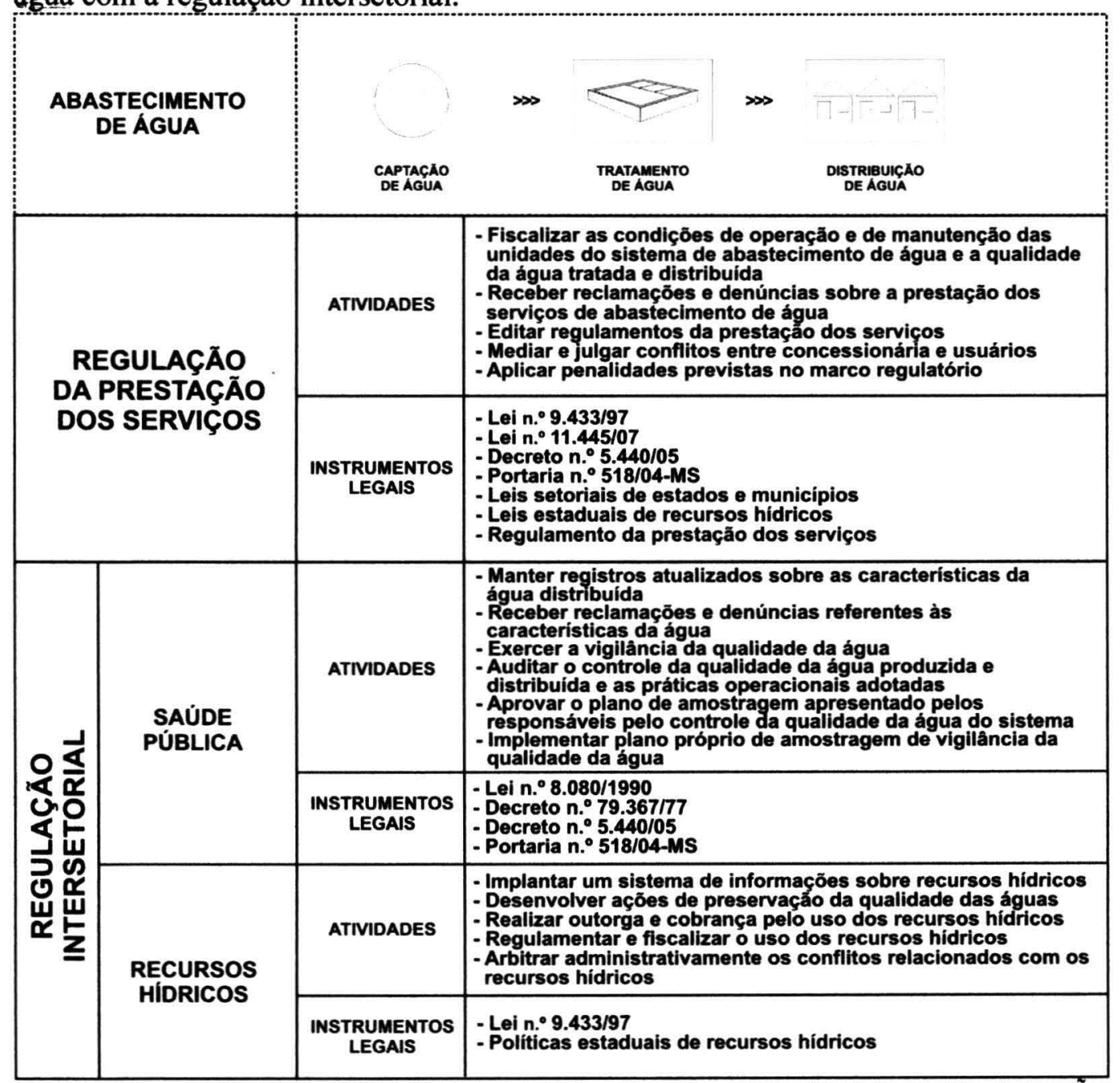

Fonte dos dados: BRASIL, 1997a; BRASIL, 2004b; BRASIL, 2005; BRASIL, 2007a; GALVÃO JUNIOR et al., 2006.

Algumas atribuições localizadas na interface da regulação setorial com a área de saúde pública estão claras; outras, não. Por exemplo, a definição dos padrões de potabilidade é competência exclusiva da legislação federal, conforme determinado pelo Decreto $n^{0} 79.367 / 1977$ (BRASIL, 1977) e pela Lei $n^{0}$ 11.445/2007 (BRASIL, 2007a). Contudo, na verificação do atendimento aos padrões de potabilidade, atividade das vigilâncias sanitárias, há margem para atuação do regulador setorial segundo os marcos regulatórios de saneamento que determinam a verificação do cumprimento das metas e dos padrões de qualidade estabelecidos nos contratos de programa e de concessão. Neste caso, tem-se uma possível sobreposição de funções. 
Ademais, a intervenção nesta área torna-se mais atrativa para os reguladores setoriais visto que os sistemas de vigilância sanitária não conseguem cumprir de forma adequada suas obrigações em relação ao monitoramento da qualidade da água para abastecimento público (BRASIL, 2006).

De acordo com (INFURB, 1995), a articulação da regulação setorial com a área de saúde proporcionaria benefícios ao setor notadamente com o aproveitamento das capacitações existentes de cada estrutura e minimização de problemas resultantes da duplicidade de funções.

No referente aos recursos hídricos, a qualidade e a quantidade da água afluente, as estações de tratamento de água e a cobrança pelo uso deste recurso são os principais aspectos do ordenamento desta área com a regulação setorial. Contudo, o relativo isolamento em que se encontra a área de recursos hídricos representa um entrave para cooperação intersetorial com o saneamento básico (Ib. Idib.).

As interfaces da prestação dos serviços de esgotamento e tratamento de esgotos ocorrem principalmente com a área de meio ambiente, conforme demonstrado na Figura 16. 
Eigura 16 - Interfaces da regulação da prestação dos serviços de esgotamento e tratamento de esgotos com a regulação intersetorial.

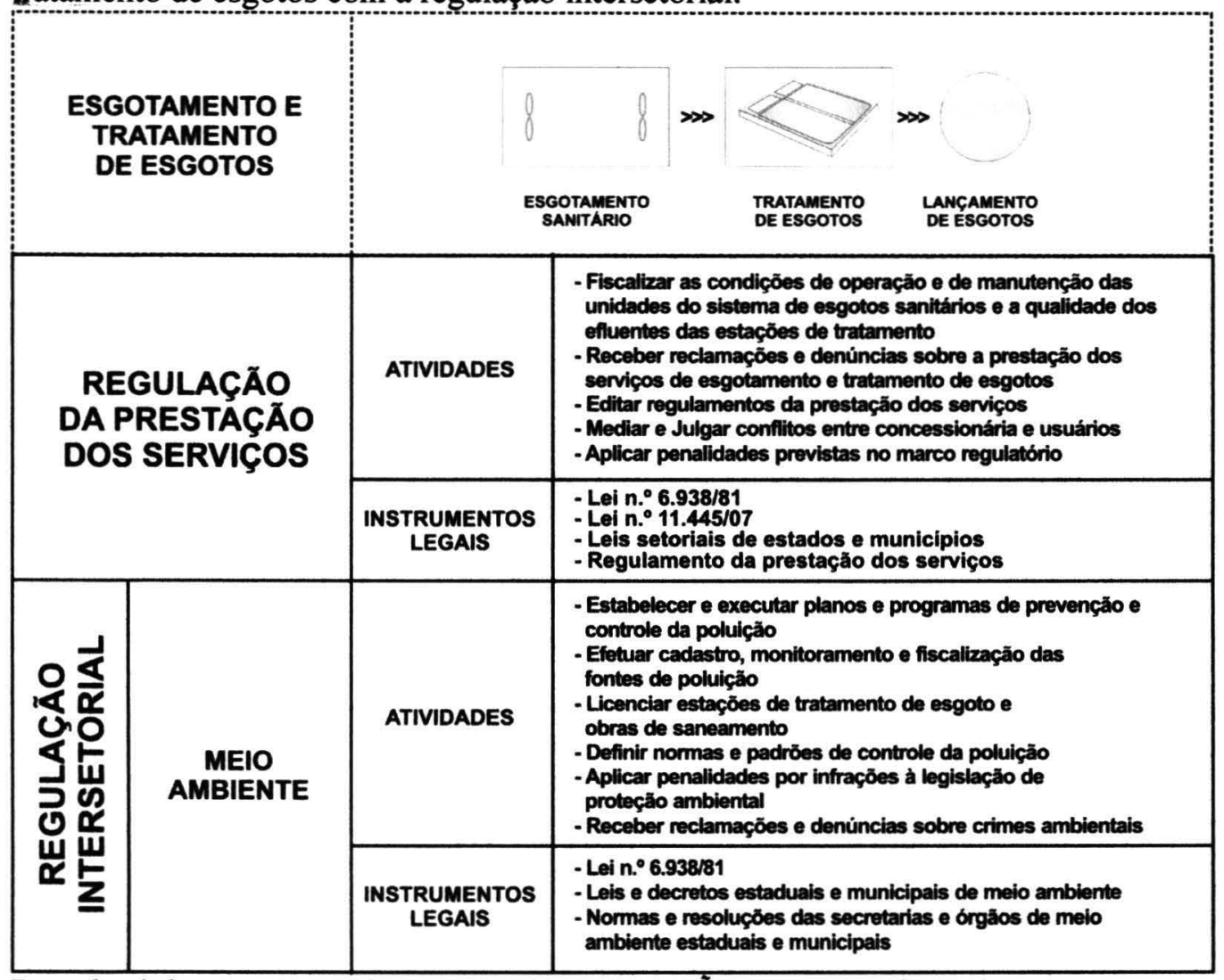

Fonte dos dados: BRASIL, 1981; BRASIL, 2007a; GALVÃO JUNIOR et al., 2006.

Em relação ao meio ambiente, o controle de qualidade dos efluentes exercido pelos órgãos ambientais torna evidente a necessidade de articulação desta área com a regulação setorial no sentido de contribuir para a definição do marco regulatório do setor de saneamento por meio de parâmetros e metas de cobertura dos serviços (CONFORTO, 2000). Além disso, os padrões ambientais apresentam impacto relevante nos custos operacionais e nas tarifas dos serviços (HOLT, 2005; TRÉMOLET e HUNT, 2006), representando mais uma razão para justificar a interlocução entre as áreas.

Por último, a etapa de comercialização dos serviços de saneamento básico tem com a área de defesa do consumidor sua principal interface, como exposto na Figura 17. 
Figura 17 - Interfaces da regulação da prestação dos serviços de comercialização dos serviços de saneamento básico com a regulação intersetorial.

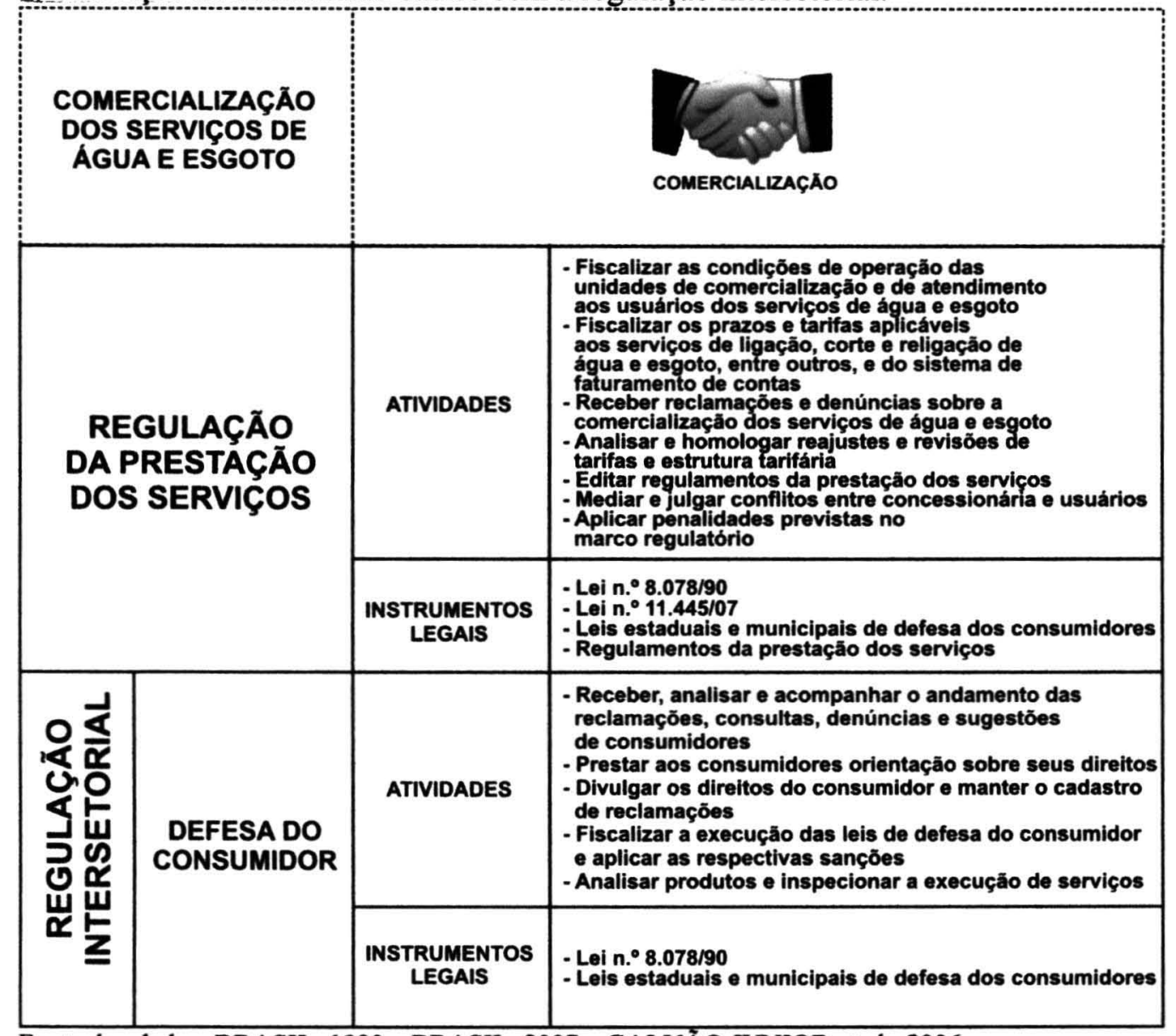

Fonte dos dados: BRASIL, 1990a; BRASIL, 2007a; GALVÃO JUNIOR et al., 2006.

No contexto desta interface é importante destacar que as agências reguladoras, por meio de suas ouvidorias, "não são órgãos de defesa do consumidor e, sim, entidades que prezam pela efetiva melhoria nos índices de qualidade, continuidade, segurança e confiabilidade da prestação dos serviços públicos essenciais" (DANTAS, 2007, p. 182). Esta definição demonstra ser mais abrangente o campo de atuação do regulador setorial que se caracteriza como órgão de proteção dos usuários dos serviços públicos, além de ser instrumento de incentivo para acesso dos não usuários a estes serviços públicos.

Desta forma, a participação do sistema de defesa do consumidor deve ser compreendida como um elemento auxiliar à regulação setorial, pois a competência para regular a prestação dos serviços é exclusiva do seu titular (INFURB, 1995). 
Não se espera que a regulação setorial venha substituir funções específicas da regulação intersetorial, mesmo quando estas atividades não estejam sendo executadas adequadamente. $\mathrm{O}$ que se busca são formas de cooperação institucional, com vistas a racionalizar custos, obter maior efetividade na atividade regulatória, e notadamente garantir melhor qualidade da prestação dos serviços. Para tanto, o arcabouço regulatório deve considerar as instituições e os instrumentos legais existentes, objetivando aproveitar suas potencialidades e introduzir soluções para as situações onde há fragilidades (EHRHARDT et al., 2007).

Além dos problemas citados, a sobreposição de funções por diferentes reguladores pode acarretar perda de credibilidade e legitimidade à medida que a aplicação de penalidades por um dos reguladores pode interferir nos procedimentos estabelecidos entre o regulador de saneamento e o prestador de serviços (PIRES e PICCININI, 1999); contestação das decisões entre as agências (FARINA et al., 1997); e produção de tensões e ineficiências entre as entidades reguladoras, também denominado de problema da "agência comum" (JOURAVLEV, 2001b).

Para se estabelecer cooperação intersetorial para a regulação dos serviços de água e esgoto, alguns obstáculos de natureza institucional e operacional precisam ser superados. Entre estes, se destacam:

- Excesso de corporativismo nas instituições;

- Incompreensão ou desconhecimento dos objetivos da regulação setorial, tanto em virtude do novo caráter desta regulação como pela falta de marco legal consolidado;

- Receio de perda de espaços institucionais e desmonte de estruturas existentes;

- Ineficiência da regulação intersetorial, em decorrência da falta de condições para atuação dos órgãos ou da ausência de recursos humanos capacitados.

Diante dos diferentes estágios institucionais e operacionais que atravessam cada um dos reguladores, qualquer forma de integração com a regulação setorial dificilmente se viabilizaria no curto prazo (INFURB, 1995). Desta forma, a construção de uma cooperação intersetorial exigiria inicialmente definir áreas de atuação convergente, estabelecimento de responsabilidades e atribuições, e definição 
de mecanismos de comunicação e de compartilhamento de informações, respeitando os limites operativos e as capacidades instaladas dos respectivos reguladores. 


\section{REgULAÇÃO DOS SERVIÇOS DE ÁGUA E ESGOTO NO NORDESTE BRASILEIRO}

\subsection{MODELO REGULATÓRIO NA LEI N ${ }^{\mathrm{O}} 11.445 / 2007$}

Conforme expresso no seu art. $1^{\circ}$, a Lei $n^{\circ} 11.445 / 07$ tem como objeto estabelecer diretrizes nacionais para o saneamento básico e a política federal do setor. Este objeto traz significativas repercussões sobre a legislação subnacional existente, assim como implica em nova legislação, sobretudo relacionada à regulação da prestação dos serviços.

Nos princípios fundamentais desta lei, algumas questões relevantes foram abordadas, como, por exemplo, a universalidade do acesso; a ênfase no planejamento via articulação institucional entre os diversos entes federados; a utilização de tecnologias e métodos apropriados que considerem a capacidade de pagamento dos usuários e a compatibilidade às condições locais e regionais; e, a busca por eficiência e eficácia na prestação dos serviços e a transparência das ações.

A lei preencheu algumas lacunas, como a regulação de sistemas interdependentes entre si operados por diversos prestadores, cuja indefinição tem sido foco de conflitos entre operadores e titulares dos serviços. Além disso, nela foram enfatizados conceitos como progressividade, gradatividade e flexibilidade, relacionados a padrões de qualidade dos efluentes gerados nas estações de tratamento de esgotos, utilização de tecnologias apropriadas e a própria universalização dos serviços, definida conceitualmente como a "ampliação progressiva do acesso de todos os domicílios ocupados ao saneamento básico" (o destaque é nosso).

Apesar do caráter abrangente da lei, que compreende as atividades de abastecimento de água, esgotamento sanitário, limpeza urbana e manejo dos resíduos sólidos, o foco central são os serviços de água e esgoto.

Como a União não é o titular da prestação dos serviços, os princípios e objetivos da política federal se limitam a contribuir, incentivar, promover e fomentar o desenvolvimento do setor. Mesmo diante desta limitação, a União dispõe de 
instrumentos, notadamente financeiros, para induzir os titulares a adotarem suas determinações para a gestão dos serviços, segundo definido no art. 50 da mencionada lei.

Em relação à articulação entre os reguladores intersetoriais, a Lei $\mathrm{n}^{0}$ 11.445/2007 não define instrumentos concretos de coordenação dos setores afins aos serviços de água e esgoto.

Quanto à regulação dos serviços, $o$ art. 21 estabelece que esta atividade deve atender aos seguintes princípios: "I - independência decisória, incluindo autonomia administrativa, orçamentária e financeira da entidade reguladora; II - transparência, tecnicidade, celeridade e objetividade das decisões".

Conforme discutido nas seções anteriores, estes princípios se consubstanciam no desenho dos entes reguladores, os quais deverão apresentar características como, por exemplo, mandatos dos dirigentes, decisão colegiada, tecnicidade e quadro de pessoal qualificado.

O Quadro 9 sumaria algumas das funções definidas para o titular dos serviços e para o regulador na lei.

Quadro 9 - Funções do titular e do regulador estabelecidas na Lei ${ }^{\circ}$ 11.445/2007.

\begin{tabular}{|c|l|}
\hline $\begin{array}{c}\text { Titular } \\
\text { Elaborar planos de } \\
\text { saneamento básico }\end{array}$ & Verificar o cumprimento dos planos de saneamento básico. \\
\hline $\begin{array}{c}\text { Delegar a prestação dos } \\
\text { serviços }\end{array}$ & $\begin{array}{l}\text { Garantir o cumprimento das condições e metas estabelecidas; } \\
\text { Garantir a fiel interpretação dos contratos. }\end{array}$ \\
\hline $\begin{array}{c}\text { Fixar direitos e deveres } \\
\text { dos usuários }\end{array}$ & $\begin{array}{l}\text { Normatizar aspectos técnicos, econômicos e sociais da prestação dos } \\
\text { serviços; } \\
\text { Receber e se manifestar sobre as reclamações dos usuários; } \\
\text { Dar publicidade aos direitos e deveres dos usuários; } \\
\text { Permitir acesso às informações sobre os serviços prestados. }\end{array}$ \\
\hline $\begin{array}{c}\text { Estabelecer } \\
\text { mecanismos de controle } \\
\text { social }\end{array}$ & $\begin{array}{l}\text { Dar transparência às ações, baseada em sistemas de informações e } \\
\text { processos decisórios institucionalizados; } \\
\text { Dar publicidade a relatórios, estudos e decisões. }\end{array}$ \\
\hline $\begin{array}{c}\text { Definir nos contratos } \\
\text { regras para fixação, } \\
\text { reajuste e revisão de } \\
\text { tarifas }\end{array}$ & $\begin{array}{l}\text { Definir as pautas das revisões tarifárias; } \\
\text { Estabelecer regras e critérios de estruturação do sistema contábil e plano } \\
\text { de contas; } \\
\text { Definir e fixar tarifas; } \\
\text { Auditar e certificar anualmente os investimentos realizados, os valores } \\
\text { amortizados, a depreciação e os respectivos saldos; } \\
\text { Estabelecer normas e mecanismos sobre tarifas, pagamentos e subsídios } \\
\text { para prestadores que realizem atividades interdependentes. }\end{array}$ \\
\hline $\begin{array}{c}\text { Intervir e retomar a } \\
\text { operação dos serviços }\end{array}$ & Recomendar ao titular a intervenção nos serviços. \\
\hline
\end{tabular}

Fonte dos dados: BRASIL, 2007a. 
Nas diversas funções há margem para atuação discricionária do ente regulador, desde que suas decisões pautem-se por critérios técnicos e em consonância as diretrizes estabelecidas no marco regulatório.

$\mathrm{O}$ atendimento às funções regulatórias elencadas no Quadro 9, segundo os princípios da regulação definidos em lei, exigirá do ente regulador elevada capacidade técnica e operacional, além de recursos financeiros para custeio das atividades. Porém, a não definição na lei de instrumentos que assegurem a autonomia orçamentária e financeira põe em risco a viabilidade do cumprimento deste princípio (MUKAI, 2007), fundamental para a efetividade da regulação.

De acordo com estudos desenvolvidos por YILMAR (1998), a regulação envolve três tipos de custo: o primeiro está relacionado à manutenção e operação das agências reguladoras; o segundo é referente aos custos incorridos pelos indivíduos, empresas e pelo próprio governo para cumprimento das determinações regulatórias; e, por último, há o custo indireto da regulação, também denominado de custo oculto, relacionado às falhas de regulação, o qual inclui os benefícios que empresas e governo teriam se não houvesse excessiva atividade reguladora. Para o caso brasileiro, ainda no início da regulação setorial, o custo se restringe preliminarmente à manutenção e operação das agências, pois os demais custos surgirão na medida em que se consolida a atividade reguladora.

Efetivamente, o financiamento da regulação nas agências com competência para atuar no saneamento básico é realizado por taxas de regulação previstas nos marcos setoriais subnacionais. No Quadro 10 constam as taxas de regulação previstas em alguns marcos legais de estados e municípios. 
Quadro 10 - Taxas de regulação das agências com competência para atuar no saneamento básico.

\begin{tabular}{|c|c|c|c|}
\hline Abrangência & Agência & Taxa de Regulação ${ }^{(1)}$ & Base Legal \\
\hline \multirow{4}{*}{$\begin{array}{l}\text { Municipal } \\
\text { Setorial }\end{array}$} & $\begin{array}{l}\text { AGERSA (Cachoeiro } \\
\text { do Itapemirim/ES) }\end{array}$ & $\begin{array}{l}1 \% \text { faturamento total e efetivo de tarifas de } \\
\text { água e esgoto pagas pelos usuários no mês } \\
\text { anterior }\end{array}$ & $\begin{array}{c}\text { Lei } n^{\circ} \\
4.876 / 2003\end{array}$ \\
\hline & $\begin{array}{c}\text { AMAE } \\
\text { (Joinville/SC) }\end{array}$ & $1 \%$ do faturamento bruto da concessionária. & $\begin{array}{c}\text { Decreto }^{\circ} \\
13.455 / 2007^{(2)}\end{array}$ \\
\hline & ARSAE (Mauá/SP) & $\begin{array}{l}1 \% \text { do faturamento bruto da Concessionária } \\
\text { (serviços de esgoto) e } 1 \% \text { do faturamento } \\
\text { bruto da Autarquia (serviços de água) }\end{array}$ & $\begin{array}{l}\text { Contrato de } \\
\text { concessão }\end{array}$ \\
\hline & $\begin{array}{l}\text { ARSBAN } \\
\text { (Natal/RN) }\end{array}$ & $\begin{array}{l}\% \text { sobre o valor do faturamento mensal } \\
\text { efetivamente arrecadado, sendo } 2 \% \text { no } 1^{\circ} \\
\text { qüinqüênio; } 1,5 \% \text { no } 2^{\circ} \text { qüinqüênio; e } 1 \% \text { a } \\
\text { partir do } 3^{\circ}\end{array}$ & $\begin{array}{l}\text { Lei } n^{\circ} \\
5.250 / 2001\end{array}$ \\
\hline $\begin{array}{c}\text { Municipal } \\
\text { Multisetorial }\end{array}$ & $\begin{array}{c}\text { AGENRENG } \\
\text { (Campo Grande/MS) }\end{array}$ & $\begin{array}{llll}1 \% \text { do faturamento mensal } & \text { da } \\
\text { concessionária }\end{array}$ & $\begin{array}{l}\text { Edital de } \\
\text { licitação }\end{array}$ \\
\hline \multirow{11}{*}{$\begin{array}{c}\text { Estadual } \\
\text { Multisetorial }\end{array}$} & ADASA (DF) & $\begin{array}{l}0,5 \% \text { do somatório dos volumes produzidos } \\
\text { de água e de coleta de esgotos sanitários } \\
\text { (m3) vezes a tarifa média }\end{array}$ & $\begin{array}{c}\text { Resolução } \\
\text { ADASA no } \\
160 / 2006 \\
\end{array}$ \\
\hline & AGENERSA (RJ) & $\begin{array}{l}0,5 \% \text { sobre o somatório das receitas das } \\
\text { tarifas auferidas mensalmente pela } \\
\text { Concessionária }\end{array}$ & $\begin{array}{l}\text { Lei } \mathrm{n}^{\circ} \\
4.556 / 2005\end{array}$ \\
\hline & AGERGS (RS) & $\begin{array}{l}\text { Valor de acordo com o faturamento bruto } \\
\text { anual do exercício anterior ao da } \\
\text { fiscalização e controle, convertido em } \\
\text { Unidade Padrão Fiscal do Estado, que varia } \\
\text { de } 13 \text { a } 77.965 \text { UPFs. (UPF/2008 = R\$ } \\
10,4257)\end{array}$ & $\begin{array}{l}\text { Lei } n^{\circ} 11.863 / \\
2002\end{array}$ \\
\hline & AGR (GO) & $\begin{array}{l}10 \% \text { sobre } \mathrm{R} \$ 0,11 \text { (onze centavos de real) } \\
\text { por } \mathrm{m}^{3} \text { de água distribuída pela } \\
\text { concessionária }\end{array}$ & $\begin{array}{l}\text { Decreto } n^{\circ} \\
5.940 / 2004\end{array}$ \\
\hline & $\mathrm{ARCE}(\mathrm{CE})$ & R\$ $214.000,00 /$ mês para o ano de $2008^{(3)}$ & $\begin{array}{l}1^{\circ} \text { termo } \\
\text { aditivo } \\
\text { Convênio } n^{\circ} \\
20 / 2001\end{array}$ \\
\hline & ARPB (PB) & $\begin{array}{l}0,5 \% \text { da receita bruta mensal faturada pelos } \\
\text { concessionários. }\end{array}$ & $\begin{array}{c}\text { Lei }^{\circ} \\
7.843 / 2005 \\
\end{array}$ \\
\hline & ARPE (PE) & $\begin{array}{l}0,5 \% \text { da receita liquida da concessionária } \\
\text { regulada, dividida em duodécimos }\end{array}$ & $\begin{array}{c}\text { Lei } \mathrm{n}^{\circ} \\
11.921 / 2000\end{array}$ \\
\hline & ARSAL (AL) & $\begin{array}{l}0,5 \% \text { do valor do benefício econômico } \\
\text { anual auferido pelo concessionário }\end{array}$ & $\begin{array}{c}\text { Lei } \mathrm{n}^{\circ} \\
6.267 / 2001\end{array}$ \\
\hline & ARSAM (AM) & Até $1 \%$ incidente sobre o valor faturado & $\begin{array}{c}\text { Lei } n^{\circ} \\
2.568 / 1999\end{array}$ \\
\hline & ARSESP (SP) & $\begin{array}{l}0,5 \% \text { do faturamento anual diretamente } \\
\text { obtido com a prestação do serviço }\end{array}$ & $\begin{array}{c}\text { Lei Compl. } \mathrm{n}^{\circ} \\
1.025 / 2007 \\
\end{array}$ \\
\hline & ATR (TO) & $\begin{array}{l}0,5 \% \text { do valor do benefício econômico } \\
\text { anual auferido pelo concessionário }\end{array}$ & $\begin{array}{c}\text { Lei }^{\circ} \\
1.758 / 2007\end{array}$ \\
\hline
\end{tabular}

Fonte: Elaboração do autor.

Nota: ${ }^{(1)}$ Taxas previstas nas disposições legais. Não há necessariamente arrecadação efetiva, pois algumas agências ainda não iniciaram as atividades regulatórias no setor;

${ }^{(2)}$ Originalmente a taxa era de até $3 \%$ do faturamento bruto da concessionária conforme a Lei Municipal $n^{\circ} 4.924 / 2003$;

${ }^{(3)}$ Valor referente à cobertura das despesas do plano de trabalho, anexo ao aditivo do Convênio. 
Segundo este quadro demonstra, o custo regulatório é maior para as agências municipais, com taxas que variam de 1 a $3 \%$, do que para as agências estaduais, cujas taxas estão em torno de $0,5 \%$ do faturamento das concessionárias. Um dos aspectos a favorecer o menor custo nas agências estaduais é o rateio dos custos de áreas comuns, como, por exemplo, atividades administrativas e ouvidoria, pelos diversos setores regulados. COWAN (2007) relata que há economias de escopo na regulação quando executada por agências multisetoriais e que o custo regulatório deve ser considerado na viabilidade desta atividade, principalmente em países em desenvolvimento.

Apesar de se considerar que a viabilidade da regulação não se limita somente ao custeio da atividade, este é um dos pontos fundamentais para garantir sua implementação nos moldes da Lei $n^{0} 11.445 / 2007$. Desta forma, ao analisarem 2.523 municípios brasileiros com até 200.000 economias ativas de água e esgoto, cujos serviços são operados por concessionárias estaduais, GALVÃO JUNIOR et al. (2008) concluíram que a regulação conforme estabelecido nesta lei, e custeada por taxa de regulação de $3 \%$ do faturamento das concessionárias, é viável somente em 65 municípios $^{27}$. Ademais, no universo pesquisado pelos autores (Id. Ibid.), constavam 820 municípios do Nordeste brasileiro, ou seja, $46 \%$ do total de municípios da região. Destes, somente em sete era viável a regulação por agência municipal.

Além dos aspectos financeiros, diversos autores relatam outras razões que dificultam a regulação setorial por parte dos municípios. A principal delas é a falta capacidade técnica para regular os serviços de água e esgoto (CONFORTO, 2000; SEROA DA MOTTA, 2004; TUROLLA, 2002). Em virtude disso, os municípios enfrentam dificuldades relacionadas à leitura acurada dos termos contratuais em bases mais técnicas bem como não possuem competência para negociar com os

\footnotetext{
${ }^{27}$ Os autores adotaram os seguintes procedimentos: 1) a amostra dos municípios foi extraída do SNIS2005; 2) Para cada município, foi calculado o somatório das economias ativas de água e de esgoto, e a receita operacional direta total; 3 ) a amostra foi dividida em três categorias: pequeno porte - até 10 mil economias de água e esgoto; médio porte - de 10.001 a 50 mil economias de água e esgoto; e, grande porte - de 50.001 a 200 mil economias de água e esgoto; 4) para cada uma destas categorias, foi definida uma agência reguladora padrão e definido seu respectivo custo; 5) calculou-se o valor arrecadado da taxa de regulação $(1,2$ e $3 \%)$ em cada município com base na aplicação destes percentuais sobre a receita operacional direta total de cada concessão; 6) por último, os custos de cada agência padrão foram comparados com os valores calculados das taxas de regulação em cada concessão.
} 
prestadores de serviço, que em geral, detêm ampla experiência, e poder político e econômico (JOURAVLEV, 2001a).

Apesar de reconhecer as vantagens da proximidade entre o município e a população, ARAÚJO (1999) alerta que a regulação por este ente federado pode resultar em decisões de natureza pessoal passíveis de prejudicar a atividade.

Estas dificuldades são ainda mais complexas quando o prestador de serviços é uma empresa privada, pois a assimetria de recursos financeiros e administrativos entre a concessionária e o município é mais evidente (ARRETCHE, 1999; SILVA, 2004). Como exemplo, VARGAS (2005) relata a experiência de regulação ${ }^{28}$ da prestação dos serviços dos municípios de Limeira (SP) e Niterói (RJ), operados por empresas privadas, nos quais, em virtude da fragilidade dos entes reguladores, há maiores riscos de captura do ente regulador pelo regulado. Até mesmo nos grandes municípios, como Buenos Aires, na Argentina, existe dificuldade para regular empresas privadas (LEE, 2000).

Assim, a desagregação da regulação no nível municipal pode ser vista como importante desafio para estabelecimento da regulação no país (MENDES et al., 2006).

Como alternativa, a Lei $n^{0} 11.445 / 2007$ permite a delegação da regulação a qualquer entidade reguladora constituída dentro dos limites do respectivo Estado, conforme definido no art. $8^{\circ}$ e no 23 , parágrafo $1^{\circ}$. Deste modo, fica facultado aos titulares não capacitados para o exercício desta atividade ou não interessados em exercê-la por ente regulador próprio delegar a agência estadual ou a consórcio criado para este fim.

Nos consórcios, TUROLLA e OHIRA (2006) consideram que a agregação dos entes federados poderá ocorrer mediante critérios políticos e conjunturais, e não sob aspectos de natureza econômica. Neste contexto, uma regulação por consórcio se contrapõe aos princípios de autonomia e independência elencados na Lei $\mathrm{n}^{\mathrm{o}}$ 11.445/2007, inviabilizando esta atividade. Ademais, a constituição de consórcio demanda elevado nível de negociação política e tempo de maturação prolongado,

\footnotetext{
${ }^{28}$ Os organismos municipais que exerciam as atividades reguladoras não possuíam características das agências reguladoras.
} 
além de não existir no país experiência concreta de regulação segundo esta modelagem institucional (GALVÃO JUNIOR et al., 2008).

$\mathrm{Na}$ delegação às agências estaduais, o elevado custo regulatório pode ser diluído entre os diversos municípios delegatários, permitindo assim a regulação, principalmente para os pequenos municípios (MENDES et al., 2006). A despeito das vantagens da agregação e considerando o modelo majoritário de prestação dos serviços no país, por Companhias Estaduais de Saneamento Básico, a regulação por agência estadual sobre empresa situada na mesma esfera de governo poderia também resultar em captura do ente regulador não só pelo regulado, mas também pelo próprio governo. Diversos são os mecanismos de interferência governamental sobre as agências como, por exemplo, contingenciamento de recursos próprios oriundos de taxas de regulação e interferência nas decisões regulatórias. Daí ser fundamental que o desenho da agência salvaguarde o ente regulador de ingerências políticas e econômicas, preservando os princípios de autonomia e independência estabelecidos na lei.

Entretanto, delegar a regulação à agência estadual não significa omissão do município no exercício desta atividade. Há diversas formas de cooperação entre municípios e agência, com compartilhamento de funções específicas, cuja modelagem depende fundamentalmente da capacidade político-institucional do município. Ante as diferentes realidades regionais e locais, INFURB (1995) corrobora esta posição ao descrever que o exercício da titularidade deve considerar vários formatos de arranjo de partilha e cooperação entre os diversos entes.

Deve-se ainda ressaltar que a participação dos municípios na gestão dos serviços abrange também a definição da política setorial configurada, sobretudo por meio dos planos de saneamento básico, conforme descrito no art. $9^{\circ}$ da Lei $n^{\circ}$ 11.445/2007. 


\subsection{OPERACIONALIZAÇÃO DA REGULAÇÃO DO SETOR DE} ÁGUA E ESGOTO

$\mathrm{Na}$ operacionalização da regulação, são efetivadas as disposições e obrigações legais estabelecidas no marco regulatório pelas agências reguladoras. A atuação de uma agência pode pautar-se sob diversas formas, a depender do marco regulatório estabelecido e da estrutura operacional, recursos financeiros e humanos disponíveis para o regulador fazer cumprir este marco.

Estudo desenvolvido por WILLAMS et al. (1988) para a National Association of Regulatory Utilities Comission, associação que congrega as comissões estaduais de regulação dos Estados Unidos, classificou a atuação das comissões em cinco estágios. $\mathrm{O}$ critério de classificação foi baseado no escopo das funções exercidas pelas comissões reguladoras americanas (Id. Ibid.).

No primeiro estágio a comissão responde às demandas e às solicitações da empresa e dos usuários, enquanto no segundo, além de responder às demandas, a comissão acompanha as empresas reguladas. No terceiro estágio, é avaliada a eficiência das atividades operacionais e de planejamento executadas pela empresa regulada. No estágio seguinte, a comissão exerce papel ativo ao regular todos os aspectos relacionados à indústria privada da água, inclusive observando a legislação e a estrutura da indústria, além dos padrões de qualidade de outras agências. Por último, o quinto estágio é caracterizado por atuação que extrapola o âmbito da empresa regulada, com foco no setor regulado como um todo. Cada estágio é cumulativo, ou seja, para atingir o nível superior, a comissão necessita cumprir todas as funções dos estágios anteriores, e também as previstas para o próprio nível.

Para o atendimento aos escopos previstos nos cinco estágios, o estudo da NARUC correlaciona três níveis de conhecimento e de capacitação dos reguladores, assim definidos: no primeiro nível, os reguladores devem ter conhecimento em auditoria de finanças e análise de documentação relativa à qualidade dos serviços. Para o segundo nível, os reguladores devem conhecer a operação dos sistemas, entender as demais regulações do setor, compreender os programas de financiamento e apoio técnico às empresas, bem como ter habilidades para realizar auditorias em 
técnicas de planejamento e de gestão dos sistemas. Para o último nível, além das habilidades dos níveis 1 e 2 , os reguladores devem ter capacidade para analisar demandas de longo prazo do setor e dos usuários, ter preparação para avaliar medidas legislativas e trabalhar em cooperação com outros reguladores, associações de usuários e de empresas.

Ao analisar a classificação do NARUC, SILVA (2006) relata não ser possível transpô-la de forma preconcebida para a realidade nacional. Efetivamente, o uso desta escala de evolução institucional guarda algumas ressalvas quando aplicada à regulação setorial no Brasil. Inicialmente, trata-se de situações institucionais distintas, pois no âmbito brasileiro prevalecem agências estaduais multisetoriais, gestão pública na prestação dos serviços e problemas de institucionalidade e de instabilidade das políticas, não aplicável ao caso norte-americano. Entretanto, a gradatividade no exercício do escopo regulatório associada a requisitos de capacitação do quadro técnico são as principais contribuições do estudo da NARUC, adaptáveis a qualquer realidade institucional. Ademais, no modelo superior de escopo deste estudo, equivalente ao quinto estágio, a regulação extrapola os limites dos contratos de concessão e da empresa regulada, condição ideal para regulação de qualquer setor da infra-estrutura.

Portanto, a definição de uma escala de evolução institucional para o Brasil deve considerar aspectos da institucionalidade brasileira e da própria configuração do setor, as quais, por muitas vezes, poderão contrariar modelos de experiências internacionais já consolidados.

Independente da evolução institucional de uma agência, de forma sintética, são quatro as principais atividades operacionais exercidas por ente regulador: fiscalização, regulação econômica, normatização e ouvidoria, todas demonstradas no Quadro 11, onde constam também os aspectos que envolvem o seu exercício. 
Quadro 11 - Considerações gerais e específicas das atividades de fiscalização, normatização, regulação econômica e ouvidoria.

\begin{tabular}{|c|c|c|c|c|}
\hline Atividades & Fiscalização & Normatização & Regulação Econômica & Ouvidoria \\
\hline 苞 & $\begin{array}{l}\text { Atividade de regulação técnica } \\
\text { exercida com vistas à verificação } \\
\text { contínua dos serviços regulados, } \\
\text { objetivando apurar se está sendo } \\
\text { efetivamente prestado de acordo } \\
\text { com as normas legais e } \\
\text { regulamentares. }\end{array}$ & $\begin{array}{l}\text { Detalhamento do marco } \\
\text { regulatório setorial mediante } \\
\text { estabelecimento de normas } \\
\text { resoluções. }\end{array}$ & $\begin{array}{l}\text { Determinação de tarifas e de } \\
\text { estruturas tarifárias suficientes para } \\
\text { prover serviços a um custo } \\
\text { adequado e promover viabilidade } \\
\text { econômico-financeira para o setor } \\
\text { no longo prazo. }\end{array}$ & $\begin{array}{l}\text { Orgão promotor do direito } \\
\text { administrativo, de natureza } \\
\text { imparcial, destinada a contribuir } \\
\text { para melhor funcionamento dos } \\
\text { serviços públicos, criando } \\
\text { condições para que a sociedade } \\
\text { reivindique seus direitos negados } \\
\text { pelas concessionárias. }\end{array}$ \\
\hline 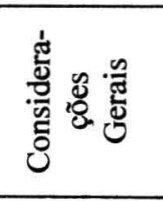 & $\begin{array}{l}\text { - Não é função do regulador intervir } \\
\text { - O regulador deve conhecer e ter } \\
\text { documentos, assim como para defini } \\
\text { - As informações referentes aos proc } \\
\text { - Para compensar a assimetria de inf }\end{array}$ & $\begin{array}{l}\text { da periodicidade do envio dos da } \\
\text { os regulatórios devem ser mantida } \\
\text { lações, o regulador deve promover }\end{array}$ & lizados pela empresa regulada; & la prestação dos serviços. \\
\hline 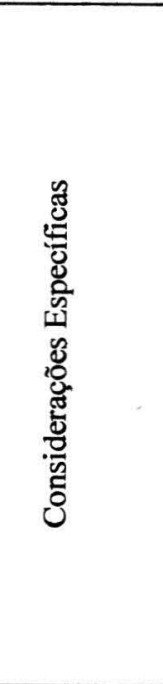 & $\begin{array}{l}\text { - A fiscalização pode ser realizada } \\
\text { de forma direta, por meio de } \\
\text { inspeção presencial nas instalações } \\
\text { operacionais, ou indireta, mediante } \\
\text { o uso de indicadores; } \\
\text { - O regulador deve ter poder de } \\
\text { entrada para realização das } \\
\text { inspeções na concessionária; } \\
\text { - As fiscalizações técnicas devem } \\
\text { ser realizadas por empresas } \\
\text { certificadas e autônomas em } \\
\text { relação às empresas reguladas; } \\
\text { - Na montagem dos indicadores, os } \\
\text { dados primários devem ter } \\
\text { rastreabilidade; a } \\
\text { - As agências devem dispor de } \\
\text { fontes de informação externas à } \\
\text { concessionária. }\end{array}$ & $\begin{array}{l}\text { - Regras específicas trazem mais } \\
\text { segurança aos prestadores de } \\
\text { serviço e previsibilidade às ações } \\
\text { do ente regulador; } \\
\text { - As normas devem ser realistas, } \\
\text { viáveis, tecnologicamente } \\
\text { racionais, passíveis de fiscalização } \\
\text { e coerentes com a realidade } \\
\text { econômica e social do setor; } \\
\text { - No processo de elaboração de } \\
\text { normas, deve haver publicidade e } \\
\text { participação dos atores do setor na } \\
\text { discussão das propostas; } \\
\text { - Na definição dos prazos de } \\
\text { vigência das normas, devem ser } \\
\text { avaliados os impactos econômico- } \\
\text { financeiros na concessão e a } \\
\text { urgência e abrangência das regras. }\end{array}$ & $\begin{array}{l}\text { - O regulador deve ter acesso às } \\
\text { informações econômico- } \\
\text { financeiras e contábeis necessárias } \\
\text { para realização das análises; } \\
\text { - Na metodologia de fixação de } \\
\text { tarifas, deve ser incorporada } \\
\text { medida de qualidade dos serviços; }\end{array}$ & $\begin{array}{l}\text { - O trabalho de ouvidoria } \\
\text { possibilita subsidiar a fiscalização } \\
\text { exercida pela área técnica; } \\
\text { - Para prover mais agilidade no } \\
\text { tratamento das reclamações dos } \\
\text { usuários, a ouvidoria deve propor } \\
\text { audiências de mediação para } \\
\text { solução dos conflitos; } \\
\text { - A ouvidoria deve receber a } \\
\text { solicitação do usuário somente se } \\
\text { este procurou inicialmente o } \\
\text { atendimento da concessionária; } \\
\text { - Compete também à ouvidoria a } \\
\text { realização de audiências e } \\
\text { consultas públicas sobre temas } \\
\text { relevantes para a concessão, como } \\
\text { revisão de tarifas e edição de } \\
\text { normas. }\end{array}$ \\
\hline
\end{tabular}

Fonte dos dados: DANTAS, 2007; EHRHARDT et al., 2007; GALVÃO JUNIOR et al., 2006; HOLT, 2005; JOURAVLEV, 2003; JOURAVLEV, 2001b;

TRÉMOLET e HUNT, 2006. 
O Quadro 11 demonstra haver uma série de particularidades a serem observadas na operacionalização da regulação e de cada uma de suas atividades.

$\mathrm{Na}$ implantação da regulação e de sua estrutura, uma das estratégias básicas a serem seguidas é a gradatividade, pois o objetivo maior da regulação é alcançar a máxima eficiência da prestação dos serviços públicos, e não o controle em si mesmo (IESP, 1995). Entre os principais problemas da gradatividade está a descontinuidade das políticas governamentais, que combinados à fragilidade institucional das agências, podem dificultar a gradatividade das ações regulatórias. Por exemplo, eventos eleitorais durante o período de consolidação da regulação setorial testam a solidez dos resultados regulatórios já alcançados, sobretudo quando as agências e a própria regulação encontram-se em formação. Objetivamente, isto pode se materializar mediante a indicação do quadro gerencial intermediário das agências, previsto em algumas leis de criação, diretamente pelo chefe do poder executivo.

Outro aspecto relevante é a não interferência do regulador nas atividades internas da empresa regulada. Esta interferência pode inibir a utilização de novas tecnologias e impactar negativamente a eficiência operacional da empresa regulada (CONFORTO, 1998). Desta forma, os reguladores devem notificar, por meio dos vários instrumentos de trabalho, as não-conformidades em relação aos resultados finais dos produtos e serviços prestados. Mas cabe a empresa regulada, dentro de uma racionalidade técnica e econômica, definir a melhor alternativa para atendimento aos padrões regulamentares e as determinações do regulador.

Para a consecução das atividades reguladoras, a obtenção de informação sobre a prestação dos serviços é fator decisivo. Como as agências dependem diretamente dos prestadores de serviços para obter informações, haverá incentivo para que as empresas se comportem de forma inadequada, subtraindo ou até mesmo distorcendo os dados fornecidos aos reguladores (FOSTER, 2005). Além disso, o regulado poderá "inundar" o regulador com excesso de informações, acima de sua capacidade de processamento (JOURAVLEV, 2003).

Com vistas à minimização deste problema, além das informações da empresa regulada, a agência reguladora deve buscar subsídios junto aos usuários dos serviços. Entretanto, SAPPINGTON (2005) adverte para os limites desta participação, porquanto há níveis e padrões de serviço que tanto os usuários como os 
próprios reguladores são incapazes de observar. Um dos exemplos desta situação é a qualidade da água distribuída. Como se trata de parâmetros físico-químicos e bacteriológicos, de não deteç̧ão visual pelos usuários, e como a fiscalização feita pelos reguladores é amostral, torna-se complexa a observância do atendimento à legislação pela empresa regulada. Neste caso, exige-se um conjunto de medidas, desde a inspeção física de laboratórios e unidades de produção de água, à verificação do controle de qualidade, de tal forma que sejam minimizados os riscos de eventuais não-conformidades na prestação dos serviços.

Por outro lado, a dificuldade de obtenção de informações, principalmente as de natureza econômico-financeira e contábil, poderá contribuir para que a agência concentre suas atividades onde seja mais fácil adquirir dados e resultados de curto prazo. Estas áreas da prestação dos serviços não necessariamente representam o foco principal das ineficiências e estão mais relacionadas à fiscalização dos serviços, como, por exemplo, medições de pressão na rede de distribuição de água.

É preciso, no entanto, para fazer cumprir as determinações do marco legal e da agência reguladora. Para isto, dispõe-se de vários instrumentos, entre os quais a aplicação de sanções administrativas à empresa regulada e a introdução na metodologia tarifária de mecanismos de incentivo à eficiência e à melhoria da qualidade dos serviços prestados.

Os valores relativos às penalidades devem ser suficientes para proverem incentivos e induzir as empresas a atuar de forma eficiente e de acordo com as disposições regulamentares (HOLT, 2005; JOURAVLEV, 2001b). No entanto, quando as penalidades são aplicadas sobre empresas públicas, há problemas de natureza política e institucional. Existem riscos de que as penalidades, quer seja pela aplicação de sanções pecuniárias, quer seja pela redução de tarifas, tenham como conseqüência o desembolso de recursos fiscais pelo titular, proprietário da empresa, para correção das ineficiências. Tal fato resulta na divisão do ônus para toda a sociedade. Assim, para a regulação de empresas públicas, EHRHARDT et al (2007) relata que inicialmente deveriam ser estabelecidas metas e responsabilidades, sem aplicação de sanções, com introdução gradual da regulação no setor. Posteriormente, com a melhoria da eficiência na prestação dos serviços, as regras relativas às sanções poderiam ser inseridas (Id. Ibid.). 
Ainda em relação às penalidades, é preciso definir a quem serão destinados os recursos oriundos das sanções. Se for o próprio regulador, haverá maior incentivo para aplicação de multas, pois os recursos aumentarão o orçamento da agência. Contudo, se os recursos forem para o titular dos serviços, poderá haver redirecionamento para outras áreas da administração pública, o que agrava ainda mais o déficit de investimentos do setor. Diante disto, uma das alternativas seria a constituição de fundos para aplicação em ações de educação sanitária e ambiental ou para orientação dos direitos e deveres dos usuários, sob coordenação da própria agência reguladora.

Ademais, para tornar efetivo o exercício de suas atividades, as infrações referentes à sonegação de informação ou encaminhamento de dados falsos ao regulador, assim como a restrição ao acesso às instalações operacionais, deveriam ser punidas com multas mais elevadas.

Para poder realizar estas atividades, a agência reguladora deverá dispor de infra-estrutura adequada e de recursos humanos capacitados para o exercício destas atividades. Neste intuito, a agência deverá ter quadros técnicos estáveis, contratados via concurso público, devidamente remunerados mediante salários compatíveis com a complexidade da atividade ou no mínimo equivalentes ao mercado privado, além de programa permanente de capacitação. Caso contrário, haverá evasão de pessoal especializado e perda de acervo técnico, situação já reportada em várias agências (GALVÃO JUNIOR et al., 2008).

Outro aspecto associado à discussão sobre os quadros técnicos é a quantidade de pessoal lotado ou previsto para as agências, em geral, com dimensionamento inferior às obrigações legais estabelecidas nos marcos regulatórios.

\subsection{REGULAÇÃO NO NORDESTE BRASILEIRO}

Nesta seção é apresentada abordagem geral e discussão sobre as agências reguladoras de saneamento básico do Nordeste com base em dados documentais e da 
literatura e nos depoimentos dos dirigentes destas agências, com vistas à obtenção de subsídios para definição de modelos regulatórios aplicáveis à região.

\subsubsection{Agência Reguladora do Estado da Paraíba}

A ARPB é uma autarquia especial, criada pela Lei Complementar $n^{\circ}$ 67/2005, dotada de autonomia administrativa, técnica e financeira, com estrutura definida pela Lei $n^{0}$ 7.843/2005. Contudo, a ARPB derivou-se da AAGISA, instituída em 2001, à qual competia também as atribuições de execução da política estadual de recursos hídricos e de fiscalização das atividades de irrigação no Estado da Paraíba (PARAÍBA, 2001). Em 2005, esta agência foi desmembrada em duas: AESA, responsável pela gestão das águas, e ARPB, com competência para regulação dos serviços de gás canalizado, energia elétrica e saneamento básico.

Originalmente a agência era vinculada à Secretaria Extraordinária do Meio Ambiente, dos Recursos Hídricos e Minerais, e posteriormente transferida para o âmbito da Secretaria de Estado da Infra-Estrutura. Atualmente, faz parte da estrutura da chefia da Casa Civil do Estado. Em relação as diferentes vinculações da agência na esfera administrativa do governo estadual, especificamente sua localização dentro da Secretaria de Infra-Estrutura poderia causar conflito de interesses, pois a maioria das empresas reguladas, como a CAGEPA e a PBGÁS, está vinculada à estrutura desta secretaria.

A única menção na Lei $n^{\circ} 7.843 / 2005$ acerca da universalização dos serviços é encontrada nos objetivos fundamentais da ARPB, que é o de "incentivar a expansão e a modernização, com vistas à sua universalização e à melhoria dos padrões de qualidade" (PARAÍBA, 2005). Deste modo, a universalidade do acesso é tratada genericamente, devendo o tema ser detalhado nos marcos setoriais de cada área da infra-estrutura regulada, já que a ARPB é um regulador multissetorial.

Para o saneamento básico, segundo o representante da ARPB, a forma como a agência pode contribuir para a universalização dos serviços seria mediante a fiscalização da CAGEPA. 
Entre as competências da ARPB incluí-se a análise e aprovação de reajustes tarifários, os quais deverão ser submetidos à homologação do governador do Estado (PARAÍBA, 2005).

A agência está em fase de preparação para a regulação dos serviços de saneamento básico. Neste sentido, na visão do representante da ARPB, o melhor formato para se trabalhar seria considerar a companhia estadual como parceira assim como o governo estadual. Esta visão de parceria é também reforçada no entendimento do representante sobre os arranjos institucionais para regulação dos serviços no Estado.

Em relação à participação social na regulação dos serviços, está previsto o Conselho Estadual de Regulação, Controle e Fiscalização, composto por oito membros. Destes, um representante do poder executivo, um do legislativo, três das concessionárias, um dos conselhos de consumidores, um dos órgãos de defesa do consumidor e um da diretoria da ARPB (PARAÍBA, 2005). Uma das funções deste conselho é a de "opinar sobre o plano de metas para universalização dos serviços públicos regulados pela ARPB e sobre as políticas setoriais a eles inerentes" (Id. Ibid.). Apesar do caráter consultivo do conselho, segundo se observa na sua composição, os usuários estão representados quantitativamente em menor número do que as concessionárias dos serviços regulados, o que contribui para aumentar o desequilíbrio entre forças sociais e econômicas no processo regulatório.

O quadro de pessoal da agência é composto em sua maioria por cargos comissionados, havendo servidores públicos cedidos por órgãos estaduais e prefeituras municipais. Esta situação, segundo o representante da ARPB, perdura desde 2002, quando da implantação da agência.

Segundo a lei de criação da ARPB, os membros do conselho diretor da agência, composto por um diretor-presidente e três diretores executivos, são de livre nomeação do governador do Estado, enquanto para os demais cargos da agência a competência é do diretor-presidente da própria agência, como mostra o organograma apresentado na Figura 18. 
Figura 18 - Organograma da ARPB

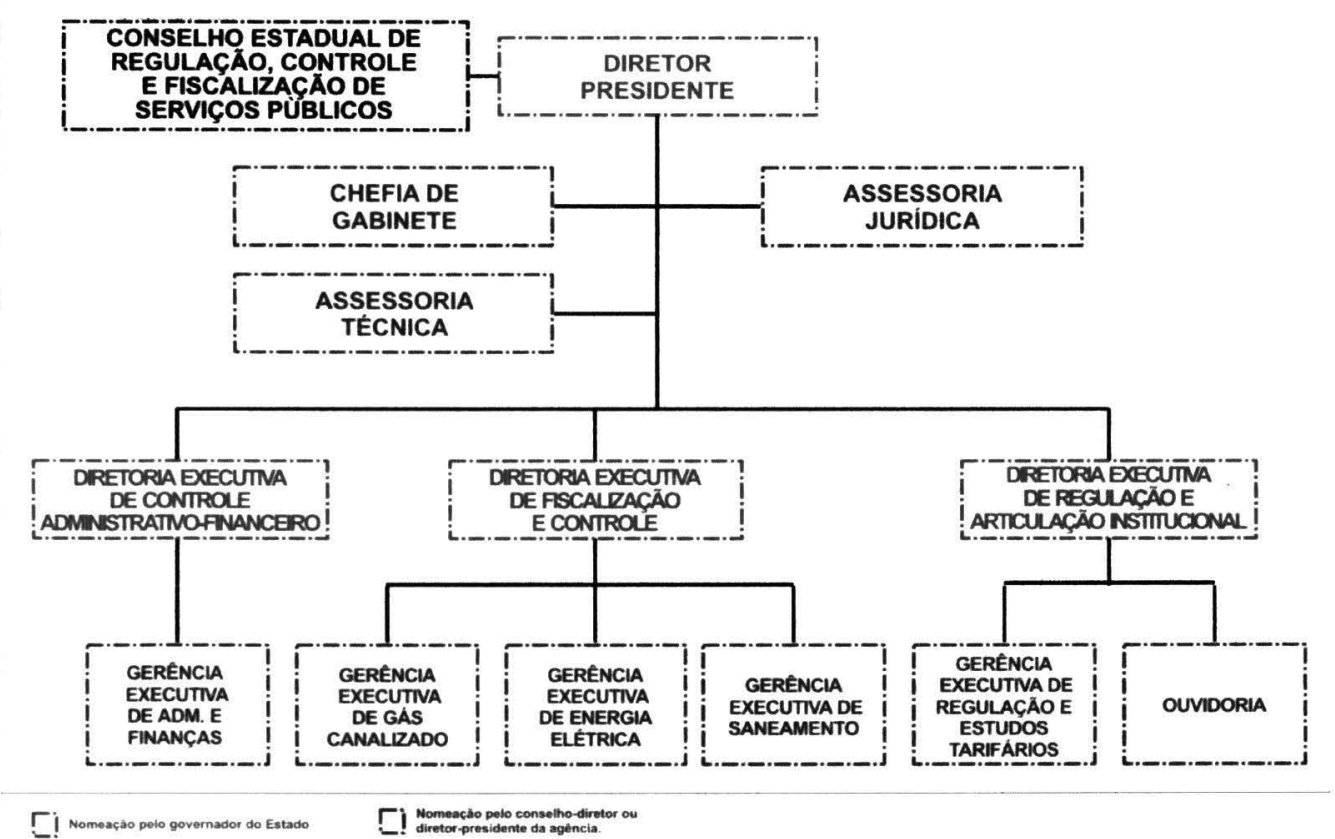

Fonte dos dados: PARAÍBA, 2005.

No tocante à coordenação com os demais reguladores setoriais, a ARPB relaciona-se exclusivamente com os órgãos de defesa do consumidor.

Ainda segundo o representante da ARPB, a evolução institucional da agência está condicionada "ao apoio que lhe seja conferido pelo governo estadual". Considerando a perspectiva de condução da regulação do setor de saneamento, mais focada para uma atuação complementar à concessionária estadual, aliada à falta de quadros técnicos concursados, é de se esperar para o Estado da Paraíba uma regulação fragilizada e insuficiente para $o$ atendimento ao disposto na Lei $\mathrm{n}^{\circ}$ 11.445/2007.

\subsubsection{Agência Reguladora de Serviços Públicos do Estado de Alagoas}

Criada pela Lei $\mathrm{n}^{\circ}$ 6.267, de 20 de setembro de 2001, a ARSAL é uma autarquia sob regime especial, dotada de autonomia administrativa, patrimonial e financeira. Como determina $a$ Lei $n^{0}$ 6.267, o "estímulo à expansão e à modernização dos serviços delegados, de modo a buscar a sua universalização e a melhoria dos 
padrões de qualidade, ressalvada a competência do Estado quanto à definição das políticas de investimento" é considerado um dos objetivos fundamentais da agência (ALAGOAS, 2001).

Ademais, conforme define o art. 35 da lei de criação da ARSAL, a agência regulará as obrigações de universalização e de continuidade conceituadas da seguinte forma:

$\S \mathbf{1}^{\circ}$ Obrigações de universalização são as que objetivam possibilitar o acesso de qualquer pessoa ou instituição de interesse público aos serviços delegados, independentemente de sua localização e condição sócio-econômica, bem como as destinadas a permitir a utilização destes serviços essenciais de interesse público.

$\S \mathbf{2}^{\circ}$. Obrigações de continuidade são as que objetivam possibilitar aos usuários dos serviços sua fruição de forma ininterrupta, sem paralisações injustificadas, devendo o serviço estar à disposição dos usuários, em condições adequadas de uso (ALAGOAS, 2001).

Em relação à compreensão do papel da agência reguladora no tocante à universalização, o representante da ARSAL entende que o "...objetivo maior de todo o regulador, principalmente de todos os dirigentes, é a universalização, de levar os serviços públicos para toda a camada da população" mas que "...é preciso que estas metas sejam definidas e planejadas adequadamente pelo poder executivo".

Desde 2002, a agência vem se preparando para regular os serviços de saneamento básico prestados pela Companhia de Abastecimento D’Água e Saneamento de Alagoas. Entretanto, esta atividade não foi implantada em virtude do não pagamento da taxa de regulação, da alta rotatividade da diretoria da estatal e da cultura auto-regulatória da empresa (LINS, 2007). De acordo com o representante da agência, a discussão da regulação dos serviços com a companhia, e não diretamente com o governo, parece ter sido um dos grandes erros estratégicos na condução da implementação da regulação do saneamento básico em Alagoas.

Desta forma, cessadas as negociações com a CASAL, como afirma o representante da ARSAL, os problemas e as opções serão levados ao poder executivo para que decida a melhor alternativa quanto à regulação dos serviços no estado. Além disso, a agência trabalha com duas possibilidades para regular os serviços: “negociar município a município, via Associação dos Municípios Alagoanos (AMA), 
e outra através da delegação expressa no marco regulatório, onde o poder regulatório ficaria a cargo da agência estadual estabelecida, no caso a ARSAL".

Contudo, o envolvimento da companhia na elaboração do desenho da agência pode conduzir a erros de concepção, porquanto há um comportamento natural de que interesses privados venham a ser preservados no marco regulatório. Isto se torna mais evidente em empresas ineficientes nas quais o excesso de corporativismo por parte da direção e do corpo técnico pode resultar em forte reação a mudanças no status quo. Assim, o envolvimento do poder executivo é essencial nas discussões de concepção do marco regulatório e da agência, devendo a participação da companhia ser postergada para outras fases do processo como, por exemplo, a regulamentação da prestação dos serviços.

A ARSAL já elaborou várias minutas de documentos para o marco regulatório estadual, entre as quais se destacam o regulamento dos serviços (ARSAL, 2007a), o contrato para concessão da prestação dos serviços de água e esgoto entre município e concessionária (ARSAL, 2007b) e o convênio entre prefeituras e ARSAL para delegação da regulação (ARSAL, 2007c). Apesar de estas minutas terem sido elaboradas antes da promulgação da Lei ${ }^{0} 11.445 / 2007$, elas sinalizam a compreensão da agência estadual sobre diversas questões regulatórias. Na minuta do regulamento da prestação dos serviços, por exemplo, há vários aspectos que apontam positivamente para a melhoria da qualidade da prestação dos serviços, e, conseqüentemente, para a universalização do seu acesso. Entre outros, exige-se que o índice de perdas seja de no máximo $35 \%$, que haja micromedição em todas as ligações de água de acordo com prazos definidos pela agência, e que as tarifas sejam objeto de aprovação da ARSAL. Diante do elevado número de funcionários da CASAL, índice de perdas físicas de $52 \%$ e inadimplência próxima a $20 \%$, além de déficit anual médio de dez milhões de reais (LINS, 2007), a regulação deve num primeiro momento promover choque de eficiência na empresa, com vistas a otimizar recursos despendidos na prestação dos serviços.

Quanto à minuta do contrato de concessão, ficam estabelecidas metas físicas e qualitativas, e exigidas apresentação de planos de exploração dos serviços qüinqüenais ao longo do período contratual, assim como regras para aplicação de penalidades em caso de descumprimento de cláusulas contratuais (ARSAL, 2007b). 
Já no convênio de delegação da regulação, a agência "assume" integralmente a condição de titular dos serviços, pois não pressupõe participação do município na regulação dos serviços (ARSAL, 2007c). Para viabilizar a regulação no Estado de Alagoas no contexto da Lei $\mathrm{n}^{0} 11.445 / 2007$, o representante da ARSAL defende que a regulação por uma agência estadual

... seria a melhor modelagem a ser aplicada até por causa de você racionar, dar uma melhor qualidade técnica a regulação. Regulação que todos nos sabemos, é cara, e que não adianta fracionar por vários entes federativos, no caso mais específico dos municípios, porque não vai ter a qualidade técnica desejável para efetuar a boa regulação.

Em relação aos recursos humanos, a agência conta com 111 funcionários, assim divididos: 15 comissionados; 63 provisórios vinculados a uma cooperativa; 10 cedidos de outros órgãos do governo estadual; 12 terceirizados; e 11 estagiários. De acordo com o representante da agência, a não existência de servidores concursados “dificulta sobremaneira a operacionalização da agência devido à evasão técnica referente aos baixos salários, bem inferiores à média de outras agências".

Segundo o organograma da agência, mostrado na Figura 19, compete ao governador do Estado a indicação de todos os cargos da agência, entretanto, em relação aos conselheiros, é necessária a aprovação da Assembléia Legislativa estadual. 
Figura 19 - Organograma da ARSAL.

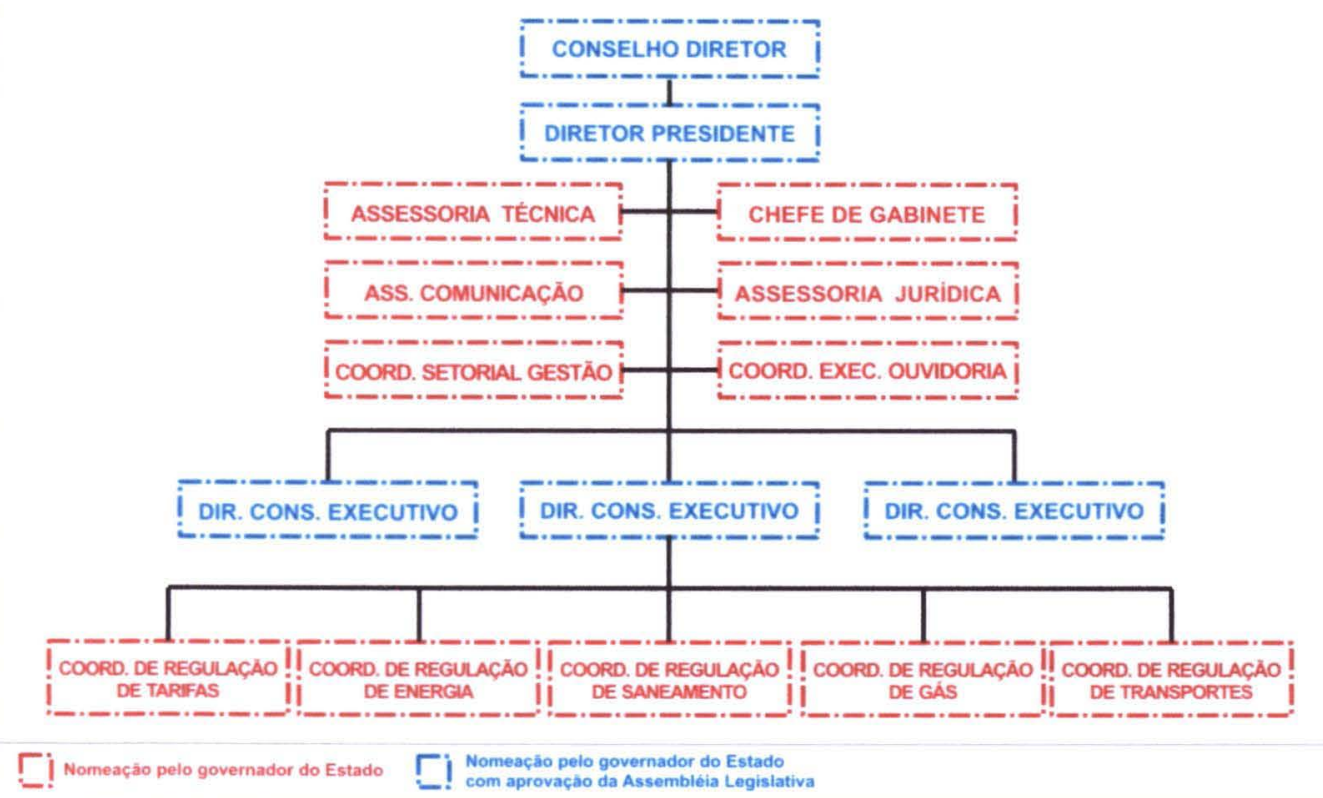

Fonte dos dados: ARSAL, 2007d; ALAGOAS, 2001.

Conforme o representante da agência, ainda não houve problemas quanto às indicações do quadro gerencial intermediário da ARSAL diretamente pelo governador do Estado. Tal fato, porém, poderá comprometer e até mesmo inviabilizar operacionalmente a agência em caso de mudança brusca de orientação política do governo estadual.

A agência está vinculada à Secretaria de Gestão Pública do governo estadual, mas a ARSAL já pertenceu às estruturas das Secretarias de Planejamento e da Fazenda do Estado, e segundo o representante da agência, o critério de vinculação é político-administrativo do Estado.

Sobre as parcerias com outros reguladores setoriais, a agência vem realizando cooperação técnica com o Instituto do Meio Ambiente do Estado, mediante o repasse do banco de dados da área de transportes com vistas ao mapeamento e zoneamento de áreas pelo órgão ambiental. Deste modo, esta parceria poderá ser estendida para outras áreas da regulação. 
4.3.3 Agência Reguladora dos Serviços Públicos Delegados do Estado do Ceará

Entre os objetivos fundamentais da ARCE, estabelecidos na Lei $\mathrm{n}^{\circ}$ 12.786/1997, que instituiu a agência, encontra-se o estímulo "à expansão e à modernização dos serviços delegados, de modo a buscar a sua universalização e a melhoria dos padrões de qualidade, ressalvada a competência do Estado quanto à definição das políticas de investimento" (CEARÁ, 1997).

A lei de criação delimita os papéis do poder concedente e da agência reguladora ao definir que compete à ARCE "implementar as diretrizes estabelecidas pelo poder concedente em relação à concessão e permissão de serviços sujeitos à competência da ARCE".

De acordo com o representante da ARCE, as atividades da agência são direcionadas para a universalização dos serviços tanto em termos qualitativos como quantitativos. Ainda segundo o representante desta agência, este direcionamento ocorre

na medida que ela analisa os custos da empresa na questão da definição das tarifas, na medida em que ela solicita e determina que a concessionária tenha uma política de tarifa social, na medida em que ela determina um plano de redução de perdas...isso direciona para a melhoria dos serviços $e$ a ampliação da universalização.

A atuação da ARCE no setor de saneamento básico ocorre desde 2001 mediante convênio entre governo do Estado, CAGECE e a agência. Por este instrumento, o governo do Estado transferiu as atribuições de fiscalização da Secretaria de Infra-Estrutura sobre a CAGECE para a ARCE, a qual ficou responsável por regulamentar a prestação dos serviços; proceder à fiscalização direta mediante auditorias técnicas; realizar análise econômica via estudo das propostas de reajuste e de revisão de tarifas e estruturas tarifárias; e apreciar as intenções dos usuários como última instância recursal administrativa para julgamento dos conflitos entre estes e a CAGECE (CEARÁ, 2001). 
Apesar da precariedade dos instrumentos de fiscalização do convênio, algumas características da atuação da agência simulam formato operacional semelhante a uma atividade reguladora. Entre eles, podem-se destacar a realização de audiências e consultas públicas para análise de revisões tarifárias, a disponibilização na internet de dados sobre a prestação dos serviços para os usuários e o atendimento de ouvidoria para solução e mediação de conflitos entre prestador de serviços e usuários. De acordo com o representante da ARCE, os principais avanços na prestação dos serviços foram

...primeiro, a questão da qualidade e do controle de qualidade. Eu acho ai foi um avanço muito grande com a atuação da $A R C E$, e em segundo lugar a transparência. Hoje em dia, todo o estudo tarifário, a qualidade dos serviços, elas são amplamente divulgadas na internet através dos indicadores que foram implementados pela ARCE.

Como exemplo, tem-se diagnóstico da agência que reportou nãoconformidades na qualidade bacteriológica da água distribuída de cinqüenta municípios do interior do Ceará operados pela CAGECE, representando um terço das concessões da companhia (SILVA, 2007). Segundo este estudo, para correção das não-conformidades foi firmado Termo de Ajustamento de Conduta com o acompanhamento das medidas corretivas mediante fiscalizações de campo pela agência (Id. Ibid.).

Em relação ao exercício do poder de recomendação da agência, a Lei $\mathbf{n}^{0}$ 12.786/1997 define entre as competências da agência a de "prestar consultoria técnica relativamente aos contratos de concessões e termos de permissões, mediante solicitação do poder concedente" (CEARÁ, 1997). O representante da agência defende maior participação da ARCE na definição das políticas setoriais de longo prazo, pois, segundo ele, é preciso "ter não só um posicionamento político, mas também um posicionamento técnico". De forma concreta, a agência esta coordenando estudos no âmbito estadual sobre contabilidade regulatória, e tarifas e subsídios, financiados pelo Banco Mundial.

O desenho institucional da agência, com mandatos dos dirigentes, funcionários concursados, capacitação técnica e coordenadorias definidas por setores, de acordo com o representante da ARCE, é o fator que melhor contribui para 
o exercício da função regulatória da agência. Como demonstra o organograma estabelecido na lei de criação, apresentado na Figura 20, os conselheiros são nomeados pelo governador do Estado, após análise curricular pública, e os cargos técnicos são escolhidos pelo conselho diretor da agência, cuja investidura é exclusiva para funcionários próprios.

Figura 20 - Organograma da ARCE.

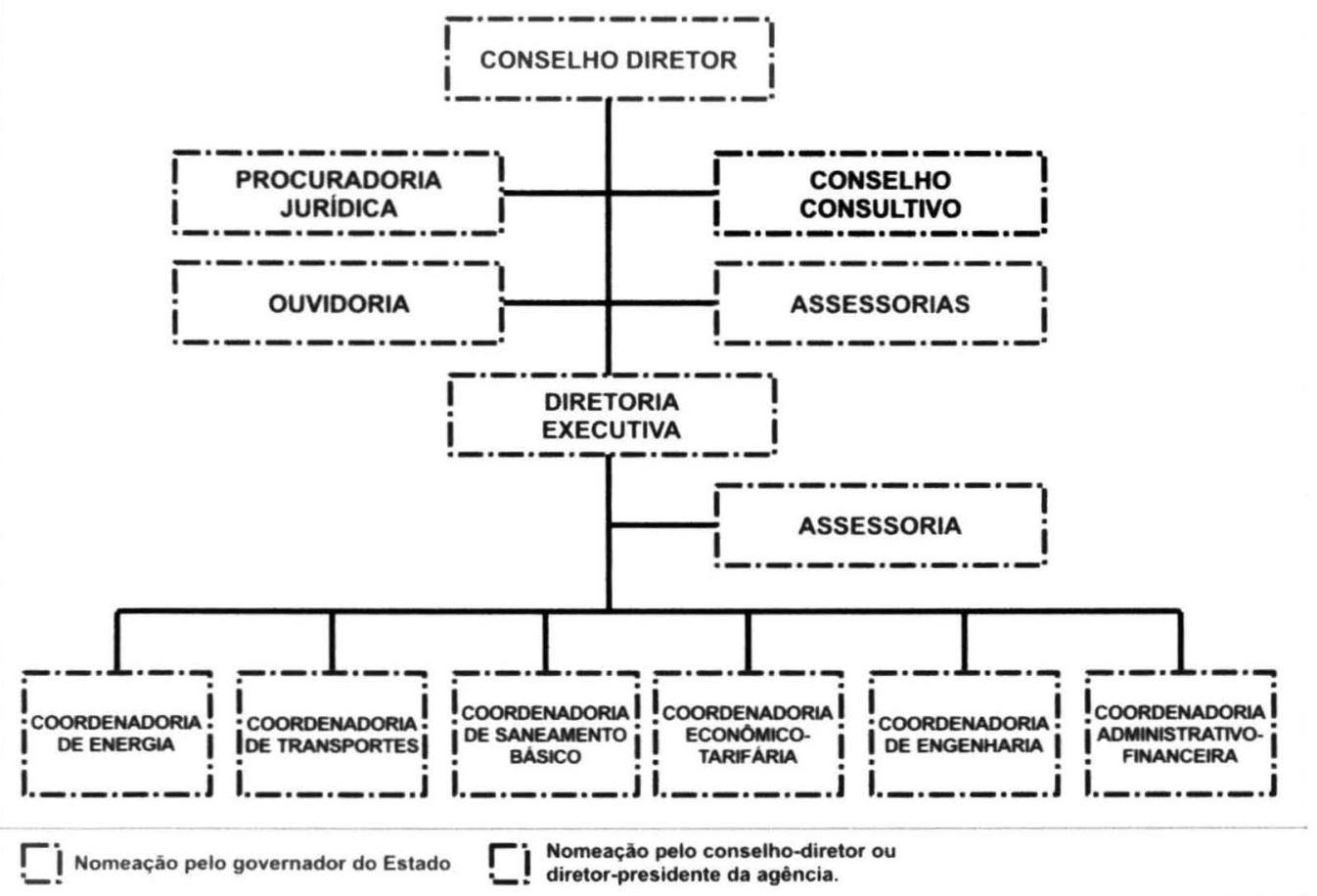

Fonte: ARCE, 2007; CEARÁ, 1997.

Não obstante a seleção dos conselheiros da agência ser pública, a aprovação pela Assembléia Legislativa do Estado poderia trazer maior legitimidade ao processo de escolha do conselho diretor.

O quadro de pessoal próprio é composto por 36 funcionários concursados, mas um terço destes se evadiu no período 2001-2006 em decorrência dos salários e da falta de perspectivas do Plano de Cargos e Salários (PCS), então existentes. Segundo o representante da agência, em 2006 foi editado um novo PCS, no sentido de corrigir as distorções, mas "não há ainda indicação segura de que a evasão foi contida, pois após o PCS dois outros servidores se afastaram da Agência para assumirem cargos em outras instituições". 
Em relação à vinculação da ARCE dentro da estrutura do governo do Estado, desde sua criação a agência esteve atrelada às seguintes secretarias e órgãos do Estado: Procuradoria Geral do Estado, Secretaria de Ouvidoria Geral e Meio Ambiente, Secretaria da Justiça e novamente Procuradoria Geral do Estado. De acordo com o representante da ARCE, "não há uma justificativa clara para a vinculação, apenas uma diretriz para garantir maior independência nas suas ações junto às entidades fiscalizadas".

Além do convênio com o governo do Estado e a CAGECE sobre 148 municípios do estado, a ARCE regula mediante delegação do município a concessão de Juazeiro do Norte, com cerca de 250 mil habitantes. Assim, são dois os arranjos institucionais de regulação sobre a prestação dos serviços no Estado do Ceará, como demonstrado no Quadro 12. 
Quadro 12 - Arranjos de cooperação entre a ARCE, governo estadual e municípios para regulação dos serviços de água e esgoto no Estado do Ceará.

JUAZEIRO DO NORTE

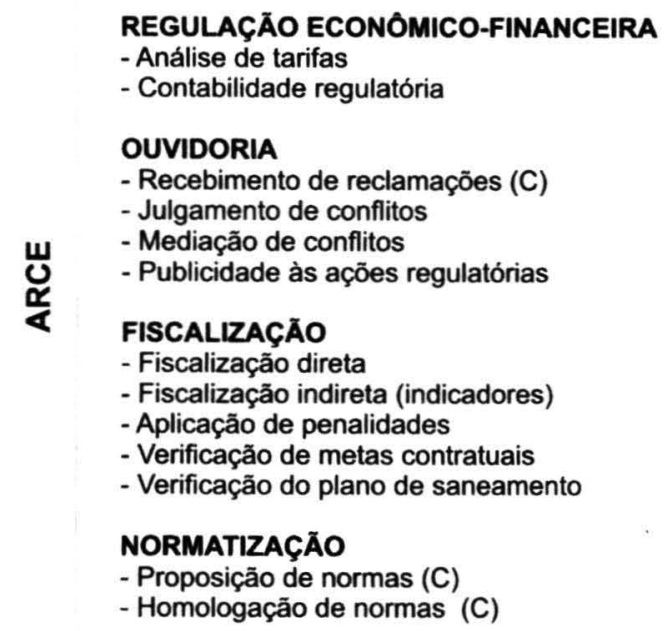

REGULAÇÃO ECONÓMICO-FINANCEIRA

- Homologação de tarifas

음

- Recebimento de reclamações (C)

NORMATIZAÇÃO

- Proposição de normas (C)

- Homologação de normas (C)

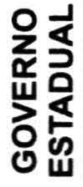

CONVÊNIO COM O GOVERNO DO ESTADO

REGULAÇÃO ECONÓMICO-FINANCEIRA

- Análise de tarifas

- Contabilidade regulatória

OUVIDORIA

- Recebimento de reclamações

- Julgamento de conflitos

- Mediação de conflitos

- Publicidade às ações regulatórias

FISCALIZAÇÃo

- Fiscalização direta

- Fiscalização indireta (indicadores)

NORMATIZAÇÃO

- Proposição de normas

- Homologação de normas

Fonte dos dados: CEARÁ, 2001; JUAZEIRO DO NORTE, 2003.

Nota: (C) - atividade conjunta entre regulador e município.

REGULAÇÃO ECONÓMICO-FINANCEIRA

- Homologação de tarifas

FISCALIZAÇÃO

- Aplicação de penalidades administrativas

De acordo com o Quadro 12, na regulação de Juazeiro do Norte, as atividades regulatórias são compartilhadas entre agência e município, enquanto no convênio com o governo do Estado e a CAGECE, o município não tem nenhuma participação. Contudo, a homologação de tarifas, aspecto relevante da regulação econômica dos serviços, é de responsabilidade do município de Juazeiro do Norte e do governo do Estado, conforme seus respectivos instrumentos de cooperação, ficando a agência com papel de assessoramento técnico.

Como os instrumentos de punição a infrações são frágeis, o representante da ARCE entende que, neste caso, os mecanismos de transparência contribuem para a 
eficácia da atividade regulatória. $\mathrm{O}$ único instrumento efetivo de punição editado pela agência é a resolução de penalidades de Juazeiro ${ }^{29}$, e que apesar de estabelecer punições que variam de 0,1 a $1 \%$ do faturamento (ARCE, 2006), os critérios de fixação de prazos para aplicação de sanções na prática reduzem a eficácia deste instrumento.

Para a regulação da prestação dos serviços de água e esgoto nos termos da Lei $n^{\circ} 11.445 / 2007$, o representante da agência entende que os municípios do estado não têm condições para o exercício da regulação.

Em relação às parcerias com os demais reguladores setoriais, há cooperação com os órgãos de defesa do consumidor, mas este relacionamento ocorre de maneira informal, de acordo com as demandas pontuais das instituições.

$\mathrm{Na}$ perspectiva do representante da ARCE, a evolução institucional no médio prazo se dará com maior autonomia financeira, administrativa e independência decisória, e maior reconhecimento de suas decisões por parte da sociedade. Para o longo prazo, o regulador da ARCE espera que a agência possa

contribuir com a universalização dos serviços, por meio, por exemplo, da atração de investimentos com regras mais claras, com a modicidade tarifária, por exemplo, com a introdução de mecanismos de incentivo que fomentem maior eficiência na prestação dos serviços, o que também contribui para a universalização, e com a sustentabilidade econômica da prestação dos serviços de água e esgoto.

Ainda segundo o representante da ARCE, o primeiro estágio já foi atingido com a promulgação da Lei $n^{0} 11.445 / 2007$, que determina a regulação por entidade independente, enquanto o segundo estágio ocorrerá com a política estadual de saneamento, adicionada a um desenho de gestão e de regulação eficientes, além da consolidação de parcerias interfederativas e intersetoriais.

\footnotetext{
${ }^{29}$ Nas demais concessões, a ARCE regula por Convênio, não havendo previsão para penalidades pecuniárias.
} 
4.3.4 Agência de Regulação dos Serviços Públicos Delegados do Estado de Pernambuco

Autarquia especial dotada de autonomia financeira, orçamentária, funcional e administrativa, a ARPE foi criada pela Lei $\mathrm{n}^{\circ} 12.126 / 2001$ e posteriormente consolidada pela Lei $n^{0} 12.524 / 2003$. Entre os objetivos desta agência se destaca o "estímulo à expansão e à modernização dos serviços públicos delegados, de modo a buscar sua universalização e a melhoria dos padrões de qualidade, ressalvada a competência do Estado quanto à definição das políticas de investimento" (PERNAMBUCO, 2003). Mencionam-se, ainda, nos objetivos a promoção da eficiência técnica e a economicidade dos serviços públicos entendidas como a prestação dos serviços com "regularidade, continuidade, segurança, atualidade, universalidade e modicidade das tarifas" (Id. Ibid.).

De acordo com o representante da ARPE, na universalização dos serviços

as decisões relativas ao encaminhamento de um processo de universalização estão acima da hierarquia das agências, estão vinculadas à formulação de políticas e o papel das agências é de monitorar e de criar os instrumentos operacionais necessários para atingir uma meta que foi definida como parte de uma política.

O organograma da agência, mostrado na Figura 21, é composto pela estrutura administrativa da ARPE e por conselho consultivo, com oito membros nomeados pelo governador do Estado e indicados por diversas instituições. Em relação à universalização, compete ao conselho "opinar sobre o plano geral de metas para universalização dos serviços prestados pelas entidades reguladas, antes do seu encaminhamento ao governador do estado, e sobre as políticas setoriais, inerentes aos serviços regulados pela ARPE, definidos pelo governo estadual" (PERNAMBUCO, 2003). 
Figura 21 - Organograma da ARPE.

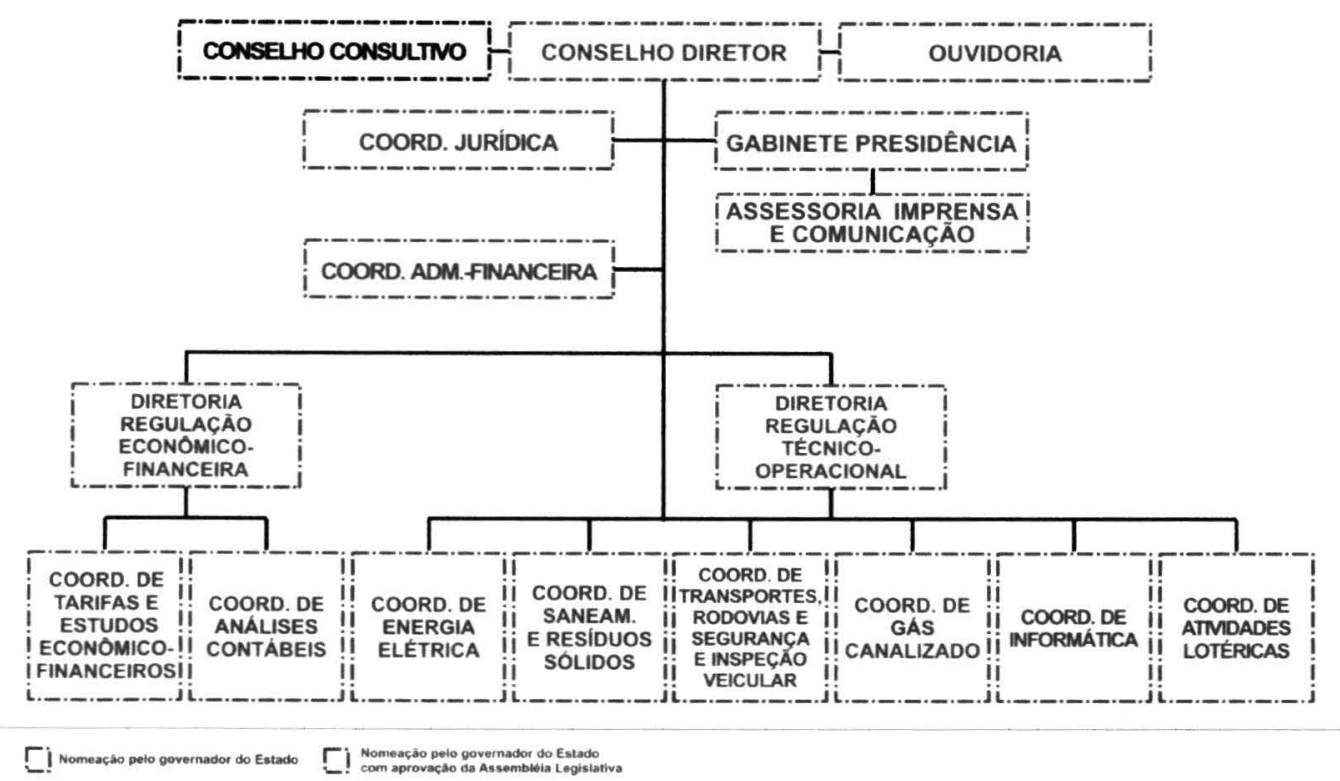

Fonte dos dados: PERNAMBUCO, 2003.

Ainda de acordo com a Figura 21, todos os cargos da agência são de livre nomeação do governador de Estado, mas os conselheiros são submetidos a aprovação da Assembléia Legislativa. O quadro de pessoal da agência é constituído por funcionários de outros órgãos do Estado, escolhidos mediante concurso interno, pessoal com contrato temporário, selecionado via concurso público, e servidores com cargos comissionados. Não há funcionários próprios concursados e a rotatividade de pessoal verifica-se apenas para os cargos comissionados.

Apesar de a indicação de cargos técnicos comissionados ser de livre escolha do governador, o representante da ARPE relata que até o presente momento não teve problemas em relação a esta questão e que este mecanismo do desenho da agência poderia ser aperfeiçoado.

Desde sua origem, a agência encontra-se vinculada administrativamente ao gabinete do governador.

Quanto à normatização do setor, a ARPE editou a Resolução $n^{0} 4 / 2007$, que estabelece as condições gerais para fiscalização técnico-operacional da COMPESA em todo o Estado. Entre outras obrigações, a resolução define metas e prazos para instalação de medidores de vazão nas entradas e saídas das estações de tratamento de água, determina eficiência mínima de conjuntos elevatórios, estabelece regras em 
caso de racionamento do fornecimento de água, e institui penalidades por descumprimento da resolução de acordo com a gravidade e a abrangência da infração (ARPE, 2007a). As multas previstas na resolução variam de $0,01 \%$ a $0,50 \%$ do valor do faturamento da concessionária referente ao exercício anterior a lavratura do auto de infração (Id. Ibid.).

Segundo o representante da ARPE, o processo de discussão da resolução contou com a participação da COMPESA, com vistas a se construir uma normatização exeqüível para a realidade do setor.

Mesmo sem a delegação dos poderes concedentes para regular a prestação dos serviços, a ARPE vem fiscalizando desde 2003 os aspectos técnicos e operacionais da COMPESA e analisando as tarifas de água e esgoto. Nesse processo, identificou determinadas não-conformidades, entre as quais: não atendimento à Portaria 518/04-MS e irregularidades das instalações operacionais da COMPESA (TAVARES et al., 2007), elevado índice de perdas físicas e de faturamento (LUNA, 2007) e problemas relacionados ao não gerenciamento dos resíduos sólidos gerados nos processos de tratamento de água e de esgotos (PRAGANA et al., 2007). Estas não-conformidades foram motivos de pactuação de programas de controle e de manutenção da COMPESA com a ARPE (LUNA, 2007; PRAGANA et al., 2007; TAVARES et al., 2007).

Especificamente em relação aos processos de revisão tarifária sob competência da ARPE, a Lei $n^{0} 12.813 / 2005$ obriga a realização de audiências públicas prévias às revisões (PERNAMBUCO, 2005). Assim, desde 2005, as revisões tarifárias $^{30}$ da COMPESA são precedidas de audiências públicas para discussão da proposta da companhia e do parecer da agência, com o objetivo de coletar subsídios para o relatório final de homologação. Nas revisões tarifárias, a análise da agência é baseada nos seguintes princípios: equilíbrio entre não onerar os usuários e não inviabilizar a saúde econômico-financeira da empresa; adequação da prestação de serviços versus eficiente utilização dos sistemas e instalações da empresa; e, maximização entre aspectos econômicos e objetivos sociais (ARPE, 2007b).

\footnotetext{
${ }^{30}$ A metodologia tarifária adotada pela ARPE para a COMPESA considera a realização de revisão tarifária com periodicidade anual.
} 
Um dos aspectos relevantes da regulação econômica realizada pela ARPE é a introdução de meta regulatória de redução de perdas nas revisões tarifárias, o que se traduz em incentivo à eficiência na prestação dos serviços. Assim, de acordo com o representante da ARPE, a metodologia adotada "pressupõe que vai reduzir as perdas, e que aquela redução de perdas diminui a necessidade de receita, e também os custos de produção. Estas duas diminuições juntas são beneficios para o consumidor". Como resultado, na revisão tarifária de 2007, a COMPESA teria aumento médio em torno de $6 \%$, mas com a aplicação da meta de redução de perdas, a reposição final ficou em torno de $3,7 \%$. Em outras palavras, a empresa deverá reduzir suas perdas para compensar a diferença entre o reajuste devido (6\%) e o homologado pela agência $(3,7 \%)$.

Para viabilização da regulação nos termos da Lei $\mathrm{n}^{0} 11.445 / 2007$, o representante da agência entende que esta deva ser homogeneizada para todo o Estado de Pernambuco, realizada pela própria ARPE.

Quanto às parcerias com os demais reguladores intersetoriais, não foi mencionada existência de instrumento formal de cooperação entre as entidades. No entanto, a ARPE participa de ações junto às entidades do meio ambiente, defesa do consumidor, vigilância sanitária e recursos hídricos.

4.3.5 Agência Reguladora de Serviços de Saneamento Básico do Município de Natal (RN)

A ARSBAN, autarquia sob regime especial, foi criada pela Lei $n^{\circ}$ $5.346 / 2001$, e tem como um de seus princípios a "universalidade dos serviços de saneamento, de modo a assegurar o mais amplo atendimento das populações, sem exclusão dos estratos de baixa renda e das áreas de baixa densidade populacional, bem como buscando garantir que tais serviços sejam prestados em todo o Município, objetivando reduzir as desigualdades e promover o seu desenvolvimento econômico e social" (NATAL, 2001a).

Para assegurar o cumprimento deste princípio, esta agência deve fixar normas, critérios e procedimentos que contenham os indicadores de qualidade dos 
serviços e de sua adequada prestação; programas, metas de expansão e qualidade dos serviços; medição, faturamento e cobrança dos serviços; métodos de monitoramento dos custos, bem como de reajustamento e revisão das tarifas; procedimentos de acompanhamento e avaliação da prestação dos serviços; e planos de contingência e segurança dos serviços (Id. Ibid.).

De acordo com o representante da ARSBAN, a contribuição da agência para a universalização dos serviços

vem no sentido de estar articulando contatos e exercendo uma certa influência, no sentido de estar cobrando que esses serviços sejam prestados, de tentar articular alguma coisa de política não partidária do ponto de vista até de auxiliar em estudos $e$ pareceres que venham contribuir para trazer investimentos para essa área.

No contrato de concessão entre a prefeitura do município de Natal e a CAERN, objeto de regulação da ARSBAN, estão fixadas metas para atendimento aos serviços de água e esgoto. Assim, para o abastecimento de água é determinado o atendimento a, no mínimo, $98 \%$ da população até o terceiro ano e cobertura total da população até o quinto ano (NATAL, 2002). Já para o esgotamento sanitário, esta instituída meta de atendimento com coleta e tratamento de esgotos a, no mínimo, $60 \%$ da população até o quinto ano; $80 \%$ até o sétimo ano; $90 \%$ até o décimo ano e o total da população até o décimo quinto ano (Id. Ibid.).

No organograma da agência, mostrado na Figura 22, todos os cargos são de nomeação direta do prefeito de Natal, tendo o cargo de diretor-presidente mandato de quatro anos. 
Figura 22 - Organograma da ARSBAN.

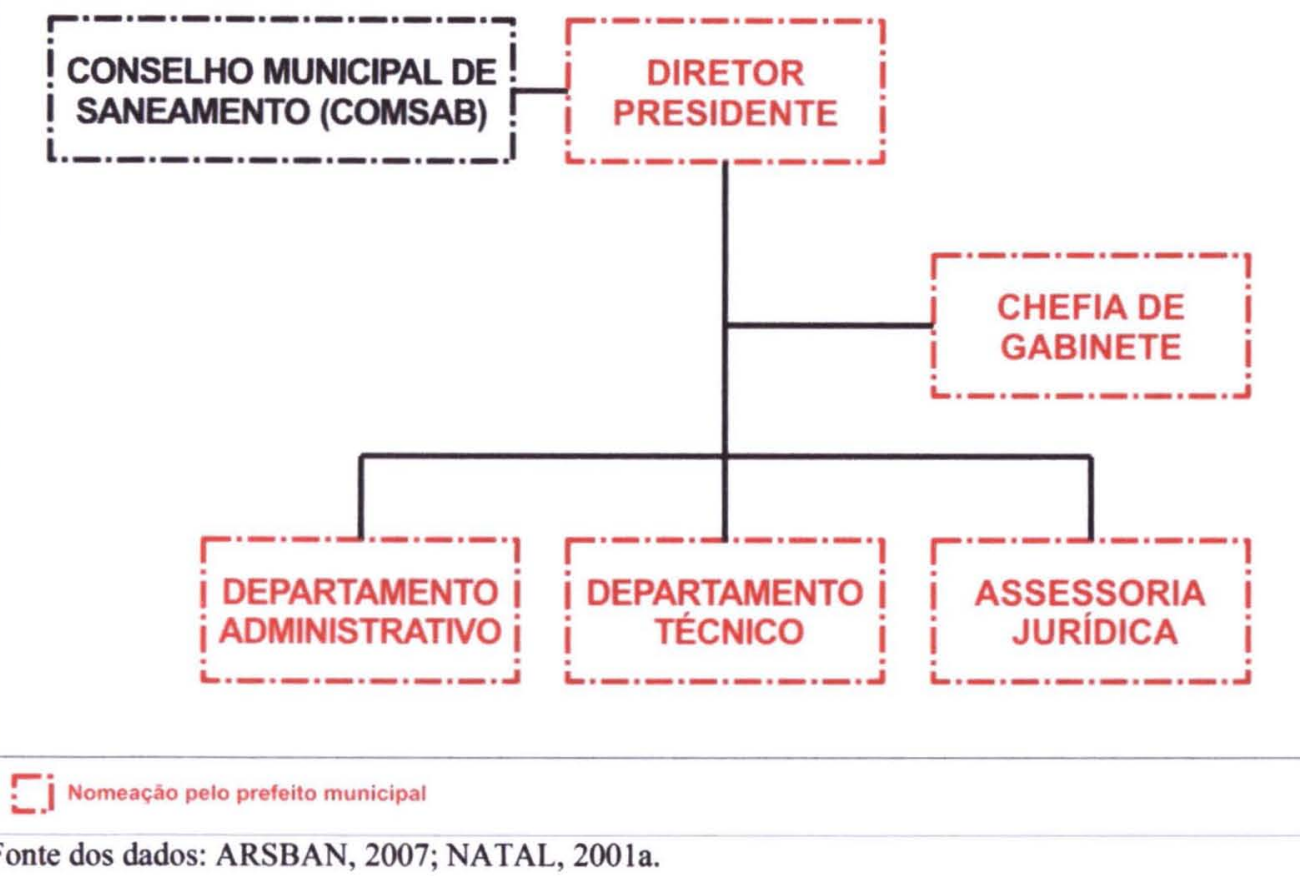

Além dos cargos comissionados apresentados na Figura 22, a estrutura de pessoal da ARSBAN é composta por prestadores de serviços e estagiários. Segundo o representante da agência, a existência de funcionários concursados possibilitaria "produzir instrumentos, além de acompanhar de forma sistemática e planejada a operacionalização dos serviços no município". Do ponto de vista administrativo, a agência está vinculada à Secretaria Municipal de Planejamento.

Ainda como mostra o organograma da ARSBAN, existe o Conselho Municipal de Saneamento Básico (COMSAB), órgão colegiado, ao qual compete, entre outras atribuições, a participação na elaboração e execução da Política Municipal de Saneamento e dos Planos Diretores de Abastecimento de Água, Drenagem, Limpeza Urbana e Esgotamento Sanitário do Município de Natal e o acompanhamento do cumprimento das metas fixadas em lei, por parte das empresas concessionárias (NATAL, 2001b). Especificamente, o contrato de concessão de Natal determina que o COMSAB seja o órgão responsável pela aprovação das tarifas dos serviços de água e esgoto (NATAL, 2002). 
A agência também incentiva a constituição de organizações dos usuários, denominadas de Associações dos Usuários dos Serviços de Saneamento Ambiental. Estas associações têm como objetivo a discussão de questões referentes aos serviços de saneamento básico em todas as suas vertentes, água, esgoto, lixo e drenagem, além da fiscalização de sua prestação (ASSIS, 2007).

De acordo com o representante da ARSBAN, o principal diferencial da agência

é o controle social que é exercido via COMSAB, que acaba exercendo um papel consultivo e deliberativo, como também por meio das associações que hoje já estão conseguindo ter uma certa projeção na cidade, até em participação em audiências públicas na Câmara de Vereadores".

Apesar de estar constituída desde 2002, a ARSBAN ainda não dispõe de instrumentos efetivos para impor sanções à CAERN por prestação inadequada de serviços. Desta forma, o representante da agência afirma que "não basta apenas fiscalizar e fazer cobranças por meio de oficios para que os problemas sejam solucionados se não há instrumentos para punição das infrações".

Mesmo com estas limitações a ARSBAN vem conseguindo estabelecer diretrizes para a contabilidade regulatória, considerada base para análise dos processos de revisão tarifária. Neste sentido o Quadro 13 apresenta balanço sintético dos últimos processos de revisão tarifária conduzidos pela ARSBAN.

Quadro 13 - Resumo das revisões tarifárias da CAERN.

\begin{tabular}{|l|c|l|}
\hline \multicolumn{1}{|c|}{ Proposta da Concessionária } & Ano & \multicolumn{1}{|c|}{ Índice Concedido } \\
\hline Reestruturação tarifária (52,3 até 150\%) & 2003 & $22 \%$ \\
\hline Revisão tarifária (24,3\%) & 2004 & $12,28 \%$ \\
\hline $\begin{array}{l}\text { Reajuste escalonado da categoria residencial temporária } \\
\text { equiparando-se à residencial normal (24,3\%) }\end{array}$ & 2005 & Pedido negado \\
\hline $\begin{array}{l}\text { Revisão tarifária e definição de normas para reajuste e } \\
\text { revisão de tarifas }\end{array}$ & 2006 & $\begin{array}{l}4,43 \% \text { e índices } \\
\text { diferenciados para o } \\
\text { consumo excedente }\end{array}$ \\
\hline
\end{tabular}

Fonte: LIMA, 2006

Em relação aos demais reguladores intersetoriais, a ARSBAN vem desenvolvendo uma série de ações conjuntas. Com a vigilância ambiental do município é mantido intercâmbio de informações sobre a qualidade da água. Para a área de recursos hídricos, a ARSBAN firmou convênio com o Instituto de Gestão das 
Águas para monitoramento dos poços da CAERN. Já em relação ao meio ambiente, foram promovidas fiscalizações conjuntas com a Secretaria de Meio Ambiente e Urbanismo e o Instituto de Defesa do Meio Ambiente com o objetivo de identificar ligações de esgoto clandestinas na rede de drenagem de águas pluviais. Por último, embora a agência não tenha atuado junto aos órgãos de defesa do consumidor, manteve relacionamento com o Ministério Público no tocante à participação em audiências e produção de estudos e pareceres passíveis de subsidiá-lo em suas ações.

\subsubsection{Considerações Gerais}

A análise dos dados levantados na documentação, literatura e depoimentos procurou identificar e discutir subsídios e aspectos críticos para o desenvolvimento da regulação na região Nordeste os quais são discutidos a seguir.

\subsubsection{Universalização}

A maioria dos reguladores compreende com clareza o papel da regulação da prestação dos serviços de água e esgoto e os limites desta atividade como instrumento de incentivo à universalização da prestação destes serviços.

A busca da universalização é descrita como princípio e/ou objetivo das agências em suas respectivas leis de criação, mas esta temática é tratada de forma genérica, devendo seu detalhamento ser contemplando nos marcos regulatórios subnacionais de cada área regulada.

Mesmo diante de instrumentos precários, foram identificadas ações próuniversalização pelas agências reguladoras que já atuam no setor, como a ARCE, a ARPE e a ARSBAN. Estas ações estão relacionadas às atividades de fiscalização, normatização, regulação econômica e ouvidoria, aparentemente criando incentivos no sentido de ganhos de eficiência, mesmo de forma incipiente, na melhoria do desempenho das empresas reguladas. 
Ademais, esta atuação tem demonstrado os danos aos quais à sociedade e os usuários dos serviços públicos estão expostos quando estes serviços não são regulados. Tal fato relaciona-se a problemas na qualidade da água distribuída, tarifas que refletem ineficiências, normas favoráveis aos prestadores de serviços, entre outros, já identificadas e em parte corrigidas por determinação das agências. Inegavelmente, algumas destas não-conformidades são graves, e podem até afetar diretamente a saúde dos usuários.

Entretanto, a busca pela universalização somente será alcançada com uma regulação adequada, de acordo com os princípios da Lei $\mathrm{n}^{0}$ 11.445/2007. Conseqüentemente, isto evidencia a necessidade de adaptação dos desenhos de agências existentes $\mathbf{e} o$ atendimento aos princípios da lei pelas novas agências, o que permitirá podem contribuir de forma mais efetiva para a universalização.

\subsubsection{Poder de recomendação}

De acordo com a maioria dos reguladores nordestinos, é relevante reforçar o papel do poder de recomendação das agências, notadamente quando da formulação das políticas públicas, apesar de haver reconhecimento dos limites de atuação destes entes nesta temática. Esta disposição das agências demonstra amadurecimento e acúmulo de conhecimento sobre o setor regulado.

No tocante à formulação das políticas subnacionais, o exercício do poder de recomendação seria relevante, pois na maioria dos Estados da região inexiste corpo técnico qualificado para discussão das questões institucionais do setor. Em alguns Estados, o quadro de pessoal das secretarias responsáveis pela área do saneamento básico é formado por funcionários emprestados das Companhias Estaduais de Saneamento Básico. Esta característica, embora não desqualifique a participação e a capaciđade técnica destes funcionários, limita esta atuação, pois eles podem influenciar o escopo das políticas públicas no sentido de preservar medidas favoráveis as companhias. 


\subsubsection{Vinculação administrativa}

Algumas das agências analisadas já tiveram mais de um lócus no âmbito administrativo do poder executivo, com destaque para a ARCE, com quatro alterações durante seus dez anos de existência. Em virtude do seu caráter especial e também inovador dentro do ordenamento jurídico brasileiro, há dúvidas sobre o lócus mais adequado para uma agência reguladora na estrutura do poder executivo. Além disso, a presença de uma agência em uma secretaria de Estado, cujo caráter limita a hierarquia do secretário ou a ingerência sobre as ações regulatórias, pode resultar em problemas de natureza política.

Há indicações de que a localização da agência na esfera do gabinete do governador de Estado poderia reforçar a capacidade de fazer cumprir as determinações regulatórias, mas, em contrapartida, poderia haver pressão mais direta por parte do chefe do poder executivo sobre a agência. Se, por um lado, há indefinições quanto à localização da agência, por outro entende-se não ser indicada a vinculação das agências às Secretarias de Infra-Estrutura ou similares, as quais estão subordinadas às empresas estatais reguladas de saneamento básico, gás canalizado, metrô, entre outras. Tal situação poderia causar conflito de interesse no âmbito da mesma estrutura administrativa, apesar da autonomia das agências reguladoras.

\subsubsection{Quadro de pessoal próprio}

Das agências analisadas, somente a ARCE dispõe de quadro de pessoal próprio concursado. Quanto às demais agências, embora já tenham passado por mais de uma gestão de governo, tempo suficiente para viabilizar a realização de concurso público, ainda não o fizeram. Como resultado, o quadro de pessoal é composto por funcionários terceirizados e comissionados. Em virtude da rotatividade deste pessoal, há volatilidade do conhecimento e restrição nos investimentos internos de capacitação do quadro de pessoal. 


\subsubsection{Indicação dos quadros intermediários}

A autonomia administrativa consta das leis de criação de todas as agências, entretanto a evidência factual sugere que há dependência em graus variados em relação aos governos. Isto decorre em virtude da centralização dos orçamentos na esfera do poder executivo e da indicação de cargos técnicos comissionados para os escalões intermediários das agências reguladoras. Com isto, há riscos de utilização de critérios políticos nas indicações, o que contraria diretamente os princípios da Lei $\mathrm{n}^{\mathrm{o}}$ 11.445/2007, assim como as recomendações derivadas da teoria da regulação.

Como alternativa, a distribuição de cargos técnicos instituída no desenho da ARCE estabelece contraponto para a politização da indicação dos cargos gerenciais, ao restringir aos servidores concursados o acesso a estes cargos.

\subsubsection{Falta de instrumentos efetivos de sanção}

Um dos aspectos a dificultar a atuação das agências reguladoras é a falta de instrumentos efetivos de sanção por inadequação à prestação dos serviços pelas concessionárias. Até mesmo onde há contrato com metas definidas, como na concessão de Natal, inexiste legislação normativa que discipline a prestação de serviços e consequentemente a punição por infrações. Somente a ARPE dispõe norma de penalidades, inserida na resolução sobre condições da prestação dos serviços, cuja aplicação é extensiva a todas as concessões operadas pela COMPESA. Além disso, a ARCE instituiu resolução específica sobre penalidades para a concessão de Juazeiro do Norte, entretanto, as restrições impostas à aplicação de sanções limitam a efetividade da medida.

A falta de instrumentos efetivos de sanção pode estar associada a dois aspectos. $\mathrm{O}$ primeiro diz respeito às vicissitudes da institucionalidade setorial, caracterizada pela falta na definição da titularidade, ausência de marco regulatório 
consistente e presença de instrumentos precários para atuação das agências, como nos casos da ARPE e da ARCE. O outro aspecto pode estar relacionado à implantação gradativa da atividade reguladora, pois nesta fase preliminar, as agências estariam se estruturando e concebendo instrumentos para atuação mais efetiva. Apesar destas ressalvas, a ausência de normatização de sanções impediu maior avanço nos resultados da regulação.

\subsubsection{Evolução institucional}

Os diferentes estágios de evolução institucional em que se apresentam a ARSAL e a ARCE, por exemplo, estão relacionados às estratégias adotadas por cada agência para a regulação dos serviços. A primeira adotou estratégia de discutir preliminarmente com a concessionária, no sentido de buscar consenso quanto aos instrumentos regulatórios, para então regular a prestação dos serviços. Como houve reação por parte da concessionária, a discussão prolongou-se por mais de três anos e resultou na não efetivação da regulação no Estado de Alagoas. Por outro lado, a discussão da ARCE foi realizada prioritariamente no âmbito do governo estadual, o qual, por determinação política, decidiu pela regulação setorial mediante instrumento de caráter precário. Em relação à concessionária, a discussão da agência se limitou às tratativas operacionais para o estabelecimento desta regulação.

Diante da estratégia exposta pelo representante da ARPB para implantação da regulação na Paraíba, semelhante àquela adotada pela ARSAL, presume-se que seja insuficiente para o estabelecimento da regulação dos serviços de água e esgoto neste Estado.

Em virtude da ausência de políticas setoriais subnacionais consistentes e da falta de diretrizes regulatórias, até a promulgação da Lei $n^{0} 11.445 / 2007$, a atuação das agências reguladoras do Nordeste brasileiro nos últimos cinco anos esteve dependente de determinados fatores, como: qualidade do desenho institucional de cada ente, capacidade de articulação dos dirigentes destas agências e conhecimento 
técnico do quadro de pessoal. Esta atuação ocorreu de forma gradativa e, em algumas circunstâncias, de comum acordo com as empresas concessionárias.

Não obstante ser necessário e salutar o diálogo permanente com os prestadores de serviço, tal comportamento deveria ser também reportado em magnitude e frequêencia apropriadas em relação aos demais atores do setor, notadamente seus usuários.

Entretanto, o processo de construção da regulação na região Nordeste da maioria das agências analisadas deve agora ser consolidado com a definição dos marcos regulatórios estaduais, em conformidade com a Lei $\mathrm{n}^{\circ} 11.445 / 2007$, os quais disciplinarão a atuação das agências reguladoras, mesmo em um contexto de indefinição da titularidade dos serviços.

\subsubsection{Arranjos para a regulação dos serviços}

A análise das agências reguladoras do Nordeste demonstra que não existe formato definido para regulação setorial nos termos da Lei $\mathrm{n}^{0} 11.445 / 07$, baseada em arranjos cooperativos que contemplem o recebimento da delegação dos municípios para o exercício da regulação.

Há, porém, expectativas de que os marcos regulatórios estaduais transfiram as atribuições regulatórias para as agências estaduais, mas estes não resolverão as situações de conflito de titularidade nos sistemas metropolitanos e integrados.

Assim, para a região Nordeste, há espaços para diferentes tipos de arranjos, com e sem a participação dos municípios no compartilhamento das atividades regulatórias. Um dos grandes desafios na concepção destes arranjos é a definição do grau desta participação, especificamente nos municípios com capacidade políticoadministrativa para constituírem entes reguladores próprios.

Quanto à regulação exercida pelo próprio município, há dificuldades para este exercício, como mostram a literatura e os depoimentos dos reguladores. 


\subsubsection{Parcerias intersetoriais}

Nas agências analisadas foram reportados poucos instrumentos formais de cooperação institucional com outros reguladores intersetoriais. Apesar de esta quantidade ser reduzida, existe muitas parcerias informais entre agências e demais reguladores.

Em geral, estas parcerias são pontuais e realizadas para atendimento a objetivos de curto prazo, sem uma política de cooperação mais ampla para consolidação da parceria.

Ademais, não há uniformidade quanto às áreas onde são realizadas as parcerias. Na Paraíba e no Ceará, por exemplo, são relatados trabalhos com a área de defesa do consumidor, enquanto em Alagoas a agência atua em cooperação com a área de meio ambiente. Já em Natal, são descritas atuações conjuntas com todas as áreas de regulação intersetorial, exceto com os órgãos de defesa do consumidor. Por último, em Pernambuco, a ARPE promove ações específicas em todas as áreas.

As não-conformidades identificadas pelas agências, principalmente quanto à qualidade da água distribuída, demonstram de forma indireta que os reguladores intersetoriais não estão cumprindo a legislação incidente. Este é, portanto, mais um motivo para coordenação entre as áreas.

\subsubsection{Quadro-resumo}

Complementarmente, no Quadro 14 apresenta-se resumo das principais características encontradas nas agências reguladoras do Nordeste brasileiro analisadas nesta pesquisa. 
Quadro 14 - Resumo das características gerais das agências reguladoras do Nordeste brasileiro.

\begin{tabular}{|c|c|c|c|c|c|}
\hline \multirow{2}{*}{ Características } & \multicolumn{5}{|c|}{ Agência reguladora } \\
\hline & ARPB & ARSAL & ARCE & ARPE & ARSBAN \\
\hline \multicolumn{6}{|l|}{ Mandato dos dirigentes } \\
\hline Critério de seleção & $\mathrm{E}$ & $\mathrm{EA}$ & $\mathrm{E}$ & EA & $\mathrm{E}$ \\
\hline Quantidade de dirigentes & 4 & 4 & 3 & 3 & 1 \\
\hline Tempo de mandato (anos) & 4 & 4 & 4 & 4 & 4 \\
\hline 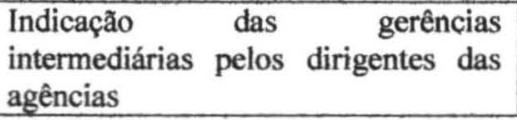 & $\checkmark$ & - & $\checkmark$ & - & - \\
\hline \multicolumn{6}{|l|}{ Atividades regulatórias em andamento } \\
\hline Fiscalização & - & - & $\checkmark$ & $\checkmark$ & $\checkmark$ \\
\hline Normatização & - & - & $\checkmark$ & $\checkmark$ & - \\
\hline Regulação econômica & - & - & $\checkmark$ & $\checkmark$ & $\checkmark$ \\
\hline Ouvidoria & - & - & $\checkmark$ & $\checkmark$ & - \\
\hline \multicolumn{6}{|l|}{ Normatização existente* } \\
\hline Condições da prestação dos serviços & - & - & $\checkmark$ & $\checkmark$ & - \\
\hline Indicadores & - & - & - & - & - \\
\hline Tarifas & - & - & - & - & - \\
\hline Subsidios & - & - & - & - & - \\
\hline Ouvidoria & - & - & - & - & - \\
\hline Contabilidade regulatória & - & - & - & - & - \\
\hline $\begin{array}{l}\text { Transferência de informações } \\
\text { regulado-regulador }\end{array}$ & - & - & $\checkmark$ & - & - \\
\hline Outros & - & - & $\checkmark$ & $\checkmark$ & - \\
\hline \multicolumn{6}{|l|}{ Participação e controle social } \\
\hline $\begin{array}{l}\text { Audiências e consultas públicas } \\
\text { realizadas no setor de saneamento }\end{array}$ & - & - & $\checkmark$ & $\checkmark$ & $\checkmark$ \\
\hline Caráter dos conselhos & $\mathrm{C}$ & - & $\mathrm{C}$ & $\mathrm{C}$ & $\mathrm{D}$ \\
\hline \multicolumn{6}{|l|}{ Quadro de pessoal } \\
\hline Concursado & - & - & $\checkmark$ & - & - \\
\hline Comissionado & $\checkmark$ & $\checkmark$ & - & $\checkmark$ & $\checkmark$ \\
\hline Terceirizado & - & $\checkmark$ & $\checkmark$ & $\checkmark$ & $\checkmark$ \\
\hline $\begin{array}{l}\text { Emprestado de outros órgãos } \\
\text { públicos }\end{array}$ & $\checkmark$ & & - & $\checkmark$ & - \\
\hline \multicolumn{6}{|l|}{ Taxa de regulação } \\
\hline$\%$ ou valor $(\mathrm{R} \$)$ & 0,5 & 0,5 & $\begin{array}{c}\mathrm{R} \$ \\
214.000,00 \\
\text { /mês } \\
\end{array}$ & 0,5 & 2 \\
\hline Base de cálculo & $\begin{array}{l}\text { Receita } \\
\text { líquida }\end{array}$ & $\begin{array}{l}\text { Receita } \\
\text { líquida }\end{array}$ & - & $\begin{array}{l}\text { Receita } \\
\text { líquida }\end{array}$ & $\begin{array}{c}\text { Faturam. } \\
\text { mensal }\end{array}$ \\
\hline Concessionária (a ser) regulada & CAGEPA & CASAL & CAGECE & COMPESA & CAERN \\
\hline Número de concessões & 175 & 77 & 149 & 169 & 1 \\
\hline
\end{tabular}

Fonte dos dados: ALAGOAS, 2001; ARCE, 2007; ARPB, 2007; ARPE, 2007c; ARSAL, 2007d; ARSBAN, 2007; CEARÁ, 1997; MCIDADES, 2006; NATAL, 2001a; PARAÍBA, 2005; PERNAMBUCO, 2003.

Nota: *Temas gerais a serem normatizados de acordo com o art. 23 da Lei $n^{\circ} 11.445 / 2007$.

Legenda: EA: nomeação pelo chefe do poder executivo com aprovação da Assembléia Legislativa; E: nomeação pelo chefe do poder executivo.

$\checkmark$ : existente; - : não existente.

C: consultivo; D: deliberativo. 
Segundo este quadro demonstra, ainda existem muitos desafios para estabelecimento da regulação nos moldes da Lei $n^{0} 11.445 / 2007$. São desenhos de agência a serem adequados, normas a serem elaboradas, concurso de pessoal a ser realizado, atividades a serem implantadas, entre outros, cuja consecução contribuirá para o fortalecimento da regulação e de seus entes e, conseqüentemente, para a busca da universalização da prestação dos serviços de saneamento básico.

Especificamente em relação à normatização dos serviços, observa-se no Quadro 14 que não existem normas específicas, principalmente quanto aos aspectos econômico-financeiros da regulação, como tarifas, subsídios e contabilidade regulatória. Com efeito, esta é uma conseqüência do avanço em termos de regulação econômica do setor, pouco significativo quando comparado à regulação da qualidade. 


\section{ESTRUTURA PARA O MODELO REGULATÓRIO}

\subsection{EVOLUÇÃO INSTITUCIONAL}

A proposta de evolução institucional das agências reguladoras estaduais de saneamento básico está baseada na análise da literatura, no estado da arte da regulação no país, na discussão com os reguladores setoriais e na experiência do autor. Trata-se, contudo, de proposição genérica visto que a busca de identidade própria e o alcance de patamares superiores de estágios institucionais se dará caso a caso, conforme cada realidade político-institucional. Da mesma forma, a agência poderá apresentar características que possibilitem enquadrá-la em diferentes estágios, porém, haverá predominância ou maior identificação com determinado nível. Além disso, não há como especificar prazos de permanência ou de mudanças para estágios superiores ou inferiores, o que ocorrerá de maneira diferente para cada agência em virtude da dinâmica do processo regulatório.

Entretanto, apesar da proposição de evolução institucional das agências reguladoras buscar indicar um ciclo de aperfeiçoamento do processo regulatório, poderá haver retrocessos no escopo proposto em função das instabilidades causadas pelos ciclos políticos e pela própria inexistência de uma cultura regulatória setorial, o que conferirá não-linearidade a evolução proposta.

$\mathrm{Na}$ Figura 23 é apresentada proposta de evolução institucional para as agências reguladoras estaduais de saneamento básico. 
Figura 23 - Proposição de evolução institucional das agências reguladoras estaduais de saneamento básico.

\begin{tabular}{|c|c|c|c|c|}
\hline & INSTITUCIONAL & OPERACIONAL & RESULTADOS ESPERADOS & ASPECTOS CRITICOS \\
\hline$\frac{0}{0}$ & $\begin{array}{l}\text { - Lei de criação da agência } \\
\text { - Instalaçâo da agência }\end{array}$ & $\begin{array}{l}\text { - Conhecimento das áreas técnico- } \\
\text { operacional e econômico- } \\
\text { financeira da empresa regulada } \\
\text { - Conhecimento dos formatos e } \\
\text { sistemas de informaçăo da } \\
\text { empresa regulada }\end{array}$ & $\begin{array}{l}\text { - Definiçắo do modus operandi } \\
\text { da agência (padrōes de relatórios, } \\
\text { estratégias de fiscalização, } \\
\text { minutas de resoluçăo, } \\
\text { entre outros) }\end{array}$ & $\begin{array}{l}\text { - Lócus da discussăo sobre a } \\
\text { concepçấo da agência } \\
\text { - Desenho da agência aprovado } \\
\text { por lei } \\
\text { - Critérios de indicação dos quadros } \\
\text { dirigente e gerencial da agência } \\
\text { - Nomeaçắo do quadro técnico } \\
\text { provisório }\end{array}$ \\
\hline 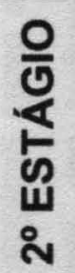 & $\begin{array}{l}\text { - Pessoal próprio concursado } \\
\text { - Recebimento da delegação } \\
\text { para regulaçăo de outros } \\
\text { entes federados } \\
\text { - Comunicaçắo com a sociedade }\end{array}$ & $\begin{array}{l}\text { - Edição de regulamentos } \\
\text { - Fiscalizaçăo técnico-operacional } \\
\text { da prestaçâo dos serviços } \\
\text { - Revisōes tarifárias em bases } \\
\text { superficiais } \\
\text { - Busca de informaçōes fora do } \\
\text { âmbito da empresa regulada } \\
\text { - Atendimento de ouvidoria }\end{array}$ & $\begin{array}{l}\text { - Melhorias em áreas específicas } \\
\text { da prestação dos serviços } \\
\text { - Transparência da regulaçāo e da } \\
\text { gestáo da prestaçãa dos serviço } \\
\text { - Respeitabilldade técnica perante } \\
\text { as empresas reguladas }\end{array}$ & $\begin{array}{l}\text { - Delimitaçăo clara dos papéis do } \\
\text { regulador e do regulado } \\
\text { - Contingenciamento de recursos } \\
\text { - Discordâncias com o governo } \\
\text { - Evasăo de quadros técnicos } \\
\text { - Forte assimetria de informações } \\
\text { - Ciclo eleitoral }\end{array}$ \\
\hline $\begin{array}{l}\frac{0}{0} \\
\frac{1}{4} \\
\text { in } \\
\stackrel{5}{10}\end{array}$ & $\begin{array}{l}\text { - Parcerias efetivas com os } \\
\text { reguladores intersetoriais } \\
\text { - Revisão do desenho institucional } \\
\text { da agência } \\
\text { - Maior permeabilidade à sociedade } \\
\text { - Participaçąo na elaboraçăo de } \\
\text { politicas públicas }\end{array}$ & $\begin{array}{l}\text { - Contabilidade regulatória } \\
\text { - Fiscalizaçäo direta e indireta por } \\
\text { meio de indicadores } \\
\text { - Fluxo regular de informaçóes } \\
\text { da empresa regulada }\end{array}$ & $\begin{array}{l}\text { - Melhoria geral na prestação dos } \\
\text { serviços } \\
\text { - Elevado nivel de conhecimento da } \\
\text { população sobre a agência } \\
\text { - Respeitabilidade técnica no } \\
\text { âmbito governamental }\end{array}$ & $\begin{array}{l}\text { - Assunção de novos encargos } \\
\text { regulatórios em agências } \\
\text { multissetoriais } \\
\text { - Priorizaçăo de outras áreas } \\
\text { reguladas em detrimento do } \\
\text { saneamento básico quando a } \\
\text { agência é multissetorial }\end{array}$ \\
\hline$\frac{0}{\frac{0}{6}}$ & $\begin{array}{l}\text { - Orçamento próprio } \\
\text { - Mudança no modelo de gestăo } \\
\text { e de prestaçắo dos serviços }\end{array}$ & $\begin{array}{l}\text { - Regulação plena } \\
\text { - Interligaçăo com os sistemas de } \\
\text { informação da empresa regulada }\end{array}$ & $\begin{array}{l}\text { - Eficiência técnico-operacional } \\
\text { na prestaçấo dos serviços } \\
\text { - Modicidade tarifária } \\
\text { - Legitimidade socia } \\
\text { - Proximidade do alcance das } \\
\text { metas de universalizaçãol }\end{array}$ & $\begin{array}{l}\text { - Reciclagem técnica contínua } \\
\text { do quadro de pessoal } \\
\text { - Introdução de competição em } \\
\text { segmentos da prestaçâao } \\
\text { dos serviços }\end{array}$ \\
\hline
\end{tabular}

Fonte: Elaboração do autor. 
Como exposto nesta figura, a caracterização de cada estágio de evolução institucional foi definida em função das seguintes variáveis: institucional, operacional, resultados esperados e aspectos críticos. As variáveis institucionais estão relacionadas à definição dos marcos institucionais, à estruturação da agência reguladora e aos seus relacionamentos intergovernamental, intersetorial e social. Já a variável operacional busca identificar o nível e o tipo de atuação nas diversas atividades regulatórias como fiscalização, ouvidoria, normatização e regulação econômica. Os resultados esperados indicam a eficiência e a eficácia da atuação da agência sobre a empresa regulada e o reconhecimento institucional e social desta atuação. Por último, os aspectos críticos representam os pontos de inflexão em relação a alteraç̃̃es dentro do próprio estágio regulatório ou de muđança para estágio inferior ou superior.

O primeiro estágio apresentado na Figura 23 é caracterizado pelas medidas legais e operacionais de implantação da agência reguladora. Neste processo, após formatação da proposta pelo poder executivo, há todo um debate políticoinstitucional entre atores econômicos, sociais e políticos no âmbito do poder legislativo para definição do modelo regulatório. Do ponto de vista operacional, a agência já instalada buscará conhecer os sistemas operacional, econômico-financeiro e de informações da empresa regulada. Baseada nestes dados preliminares e nas metas estabelecidas no marco regulatório, a agência definirá o padrão operacional de regulação dos serviços, o qual inclui minutas de resolução, informações a serem requisitadas à empresa regulada, formatos de relatórios, capacitação do quadro de pessoal, contrataçð̃es de consultoria de apoio, entre outros.

Há importante questão sobre a participação da empresa regulada nas discussões sobre a concepção da agência reguladora. A questão subjacente se refere ao potencial de pressão por manutenção de interesses corporativos ou privados. Além disso, os critérios de nomeação, seja do quadro técnico ou do corpo dirigente, devem conter requisitos associados ao conhecimento econômico, jurídico e técnico do setor a ser regulado, pois escolhas politicas podem desvirtuar ou atrasar a implantação das medidas preliminares de estruturação da agência reguladora.

No segundo estágio, são tomadas as primeiras iniciativas de ordem institucional e legal que darão identidade e concretude à atividade regulatória. São 
esperados neste estágio os primeiros resultados, embora pontuais, de melhoria da qualidade da prestação dos serviços, cujos procedimentos e métodos adotados poderão gerar conflitos de natureza política com a concessionária e o governo. Contudo, esta atuação inicial, se pautada em critérios técnicos, poderá conferir ao ente regulador credibilidade perante a empresa regulada. Em relação à estruturação da agência, a inexistência de salários e de planos de carreira compatíveis com a função reguladora poderá resultar em evasão de quadros técnicos concursados, inclusive já capacitados para o exercício da atividade.

Quanto ao terceiro estágio, espera-se que a agência detenha amplo conhecimento da empresa e do setor regulado, com resultados concretos, o que the garantirá reconhecimento no âmbito intragovernamental. Diante disto, a agência buscará consolidar sua atuação no setor mediante parcerias com reguladores intersetoriais, no sentido de racionalizar a atividade reguladora, e proporcionar-lhe maior foco nas questões fundamentais como custos e tarifas. Em decorrência do caráter multissetorial da agência e dos resultados alcançados na regulação do setor de saneamento, poderá haver mudança nas prioridades da agência, com centralização dos esforços em áreas onde eventualmente ocorram problemas de natureza regulatória. Ao mesmo tempo, estes resultados credenciam a agência para assumir novos encargos em áreas ainda não reguladas, tipo resíduos sólidos e projetos especiais como, por exemplo, as parcerias público-privadas. Ademais, a agência poderá exercer efetivamente seu poder de recomendação participando da elaboração das políticas públicas setoriais com sugestões e propostas.

Por fim, no quarto estágio, a estabilidade da função regulatória propiciará à agência indicar ao poder concedente mudanças no modelo de gestão e de prestação dos serviços com vistas a avançar na universalização e no aumento da eficiência do setor. Neste contexto, a agência adquirirá legitimidade social, fase mais avançada para a consolidação da regulação e, sobretudo proximidade do alcance das metas de universalização. Ainda neste contexto, exige-se manutenção permanente de capacitação do quadro de pessoal para que não haja acomodação em virtude dos resultados já alcançados. A maturidade do setor poderá ainda criar ambiente favorável para introdução de competição em segmentos da prestação dos serviços, o que poderá se tornar um ponto de inflexão na regulação do setor. 
Ao se considerar o atual estágio das agências reguladoras setoriais de saneamento básico no Nordeste brasileiro e até mesmo no âmbito nacional, a maioria encontra-se no primeiro estágio, e poucas em fase de transição para o segundo estágio de evolução institucional. Mesmo assim, muitas agências não conseguirão sequer alcançar estágios superiores visto apresentarem inúmeros problemas, como:

- Indicação política dos quadros dirigente e gerencial;

- Falta de credibilidade técnica motivada pela ausência de pessoal qualificado e concursado;

- Contingenciamento de recursos próprios;

- Interferência governamental nas decisões regulatórias;

- Captura pelas empresas reguladas;

- Excesso de controle social, provocando "engessamento" do exercício da atividade reguladora.

Há de se considerar ainda que o ambiente político-institucional externo poderá trazer repercussões para as agências reguladoras de saneamento básico. $\mathbf{A}$ própria definição da lei geral das agências, em discussão no Congresso Nacional por meio do Projeto de Lei $\mathrm{n}^{\circ} 3.337 / 04$, provocará rebatimentos nas legislações subnacionais e, conseqüentemente, nas agências reguladoras estaduais.

\subsection{COOPERAÇÃO INSTITUCIONAL ENTRE AGÊNCIAS REGULADORAS ESTADUAIS E MUNICÍPIOS}

As bases em que se devem assentar as formas de cooperação entre agências reguladoras estaduais e municípios para a regulação dos serviços dependem da capacidade político-institucional e administrativa do titular dos serviços de cada concessão. Estes arranjos devem abranger formas com e sem compartilhamento de funções regulatórias. Assim, como mostra o Quadro 15, são propostos arranjos de cooperação via delegação plena da regulação às agências estaduais, delegação compartilhada com os municípios em dois níveis e delegação compartilhada agregada. 
Quadro 15 - Arranjos de cooperação entre agências reguladoras estaduais e municípios para regulação dos serviços de água e esgoto.

\begin{tabular}{|c|c|c|c|c|}
\hline & DELEGAÇAO PLENA & $\begin{array}{l}\text { DELEGAÇÃO C } \\
\text { RESTRITA }\end{array}$ & $\begin{array}{l}\text { APARTILHADA } \\
\text { AMPLA }\end{array}$ & $\begin{array}{l}\text { DEEGACAO } \\
\text { COMPARTHHADAAGPEGADA }\end{array}$ \\
\hline & 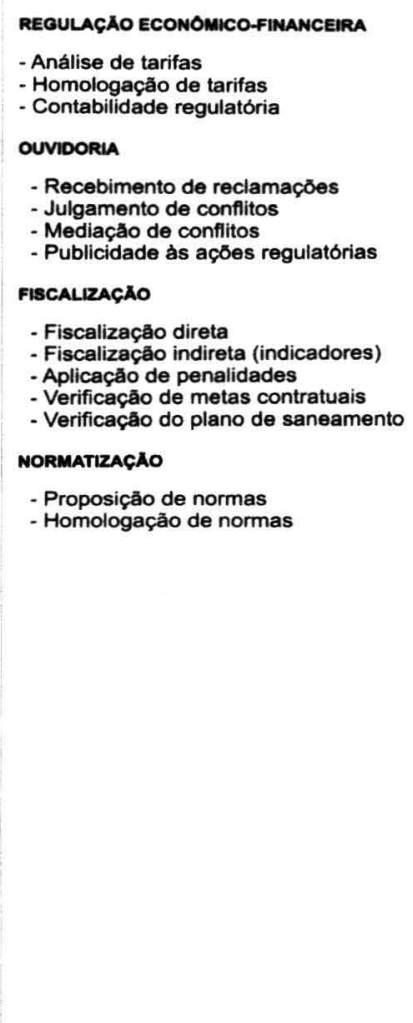 & 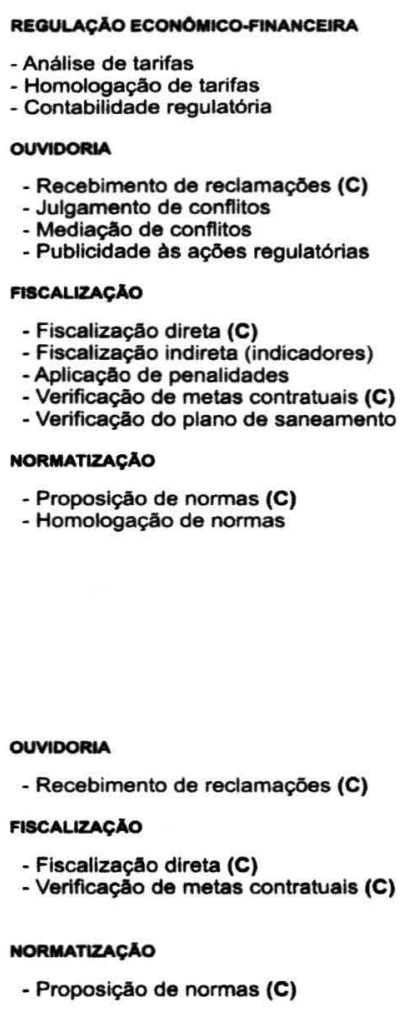 & 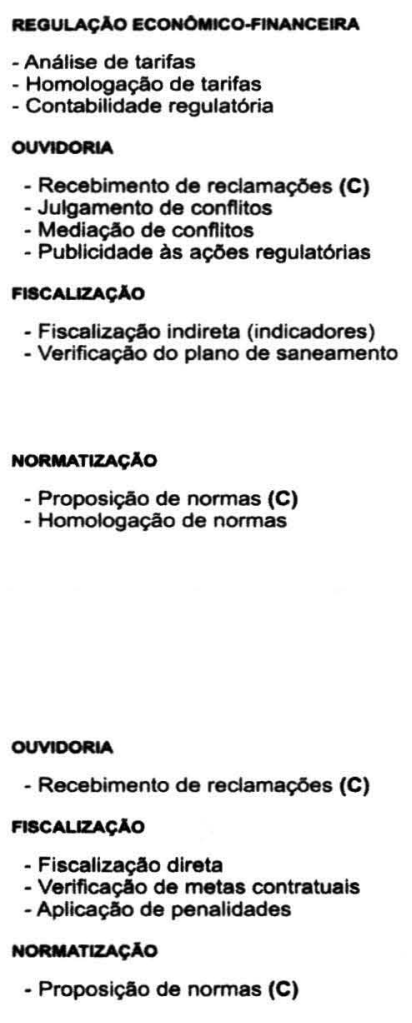 & 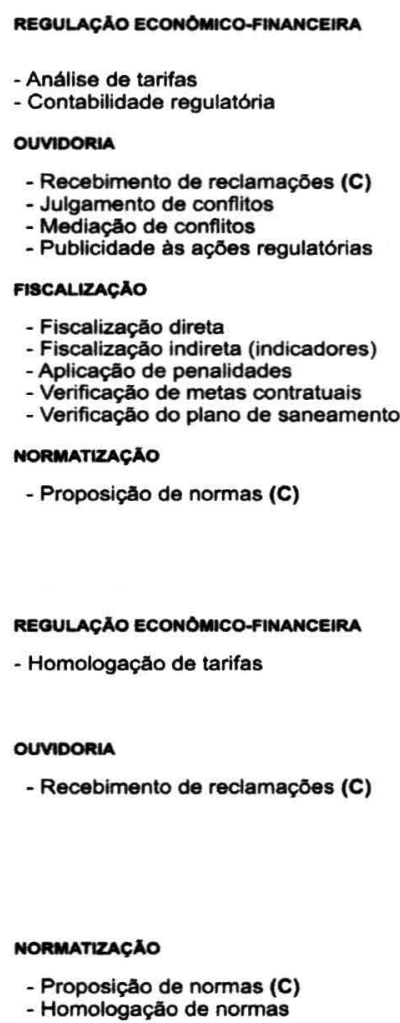 \\
\hline
\end{tabular}

Fonte: Elaboração do autor. $\quad$ Nota: (C) - atividade conjunta entre regulador e municipio. 
Como consta o Quadro 15, entre as atividades regulatórias que serão objeto de delegação encontram-se a fiscalização da prestação dos serviços direta e indireta e a aplicação de penalidades; ouvidoria para recebimento de reclamações, mediação e julgamento de conflitos entre poder concedente, concessionária e usuários dos serviços; regulação de tarifas mediante análise e homologação de reajustes e revisões tarifárias e contabilidade regulatória; e normatização por meio de proposição e homologação de resoluções para a prestação dos serviços.

No primeiro modelo proposto, a delegação plena, a transferência das atividades de regulação para a agência estadual é integral. Tal arranjo resulta da incapacidade do município de assumir ou dividir atribuições regulatórias. Assim, as funções de fiscalização, regulação de tarifas, normatização, ouvidoria ficariam a cargo das agências estaduais. Como contrapartida, a agência deve prestar contas de suas atividades realizadas no âmbito da concessão em formato e frequência definidos pelas partes. Este formato de prestação de contas deve ser suficiente para evitar o isolamento da agência reguladora do município e, conseqüentemente, dos usuários dos serviços, que delegaram a regulação.

Para o segundo formato, a delegação compartilhada, a execução das atividades regulatórias seria dividida entre a agência estadual e o município. No primeiro nível, de maneira restrita, o município poderia exercer conjuntamente com a agência estadual o recebimento de reclamações dos usuários, propor normas, fiscalizar a prestação dos serviços e as metas contratuais. Já no segundo nível, no formato amplo, aplicável para municípios maiores e com elevada capacidade administrativa e institucional, algumas atividades especificas ficariam sob a responsabilidade exclusiva do município, notadamente aquelas relacionadas à fiscalização dos serviços. Entende-se que no formato de delegação compartilhada, a competência para regular tarifas deve ser exclusiva da agência, no sentido de se evitar qualquer tipo de interferência política nesta área.

No último formato, a delegação compartilhada agregada, caberia aos municípios em conjunto com outros atores sociais, via Conselho Estadual de Saneamento ou similar, homologar tarifas e normas para a prestação dos serviços. Neste caso, o conjunto dos titulares seria representado por pequeno grupo de municípios, de acordo com critérios de representação regional, ou por tamanho de 
município. Neste contexto, uma menor gama de atribuições específicas aos municípios seria compensada pelo maior controle social e nível de responsabilização do conselho estadual na definição de normas e tarifas. A delegação compartilhada agregada da regulação poderia ser aplicada em estados onde o nível de associativismo entre os municípios encontra-se em estágio elevado de organização.

Da mesma forma, esta modelagem pode ser a mais adequada para regióes metropolitanas e integradas, onde ocorram conflitos sobre a titularidade. Esta solução, respaldada pela Lei $\mathrm{n}^{\circ} 11.445 / 2007$, dividiria atribuições regulatórias relevantes, como, por exemplo, homologação de tarifas e normas, entre municípios e estados.

Independente de qualquer forma de cooperação estabelecida entre agências reguladoras e municípios, a comunicação, prestação de contas e transparência das ações são elementos-chave no desenvolvimento da atividade reguladora. 


\section{CONCLUSÃO}

A pesquisa desenvolvida permitiu concluir que é objetivo da regulação alcançar eficiência e equidade na prestação dos serviços. Existem, porém, limites nesta atuação e as políticas e metas redistributivas devem ser fixadas pelos atores políticos, que possuem legitimidade via processo eleitoral.

Além disso, para que o modelo de regulação por agências contribua efetivamente com a universalização dos serviços, os entes reguladores devem ser concebidos e capacitados para o exercício de suas funções. A concepção de uma agência envolve o desenho institucional, baseado nos princípios de independência e de autonomia que a atividade exige, e se constitui nos mandatos para os dirigentes, na transparência dos procedimentos, na tecnicidade das decisões e na existência de mecanismos de controle social, entre outros. Em relação à capacitação, é necessário que o quadro de pessoal da agência seja selecionado mediante critérios técnicos, via concurso público, com treinamento permanente e salários compatíveis com a complexidade das funções regulatórias.

Quanto ao arranjo institucional para regulação da prestação dos serviços de água e esgoto, conclui-se que não existe padrão, pois as características do modelo de gestão do setor, associadas às condições socioeconômicas e político-administrativas da região Nordeste, levam à adoção de soluções caso a caso, próprias da institucionalidade brasileira. Desta forma, é fundamental dispor de vários arranjos institucionais para a regulação adequados às diferentes realidades regionais e locais.

Especificamente em relação às agências reguladoras do Nordeste brasileiro, observou-se na maioria destas entidades, a existência de desenhos institucionais inadequados, permeabilidade do ente regulador a influencias de natureza política, falta de quadros técnicos estáveis e de instrumentos efetivos de sanção, cujas consequências podem retardar ou até mesmo inviabilizar a regulação setorial em vários estados. Entre os fatores que contribuem para este contexto estão a existência de instrumentos precários para regulação e a ausência de cooperação institucional entre agências reguladoras e municípios para o exercício desta atividade. Assim, a elaboração e implementação dos marcos regulatórios subnacionais de acordo com os 
princípios da Lei $\mathrm{n}^{\circ} 11.445 / 2007$, permitirão definir mecanismos concretos para o desempenho adequado da regulação e de seus entes, bem como oferecerão oportunidades para reformulação dos desenhos institucionais das agências existentes.

Não obstante estes problemas, as experiências em andamento têm criado incentivos no sentido de ganhos de eficiência nas empresas reguladas, mesmo de forma incipiente, o que contribui para a busca da universalização dos serviços.

Apesar de a pesquisa ter como foco a regulação por agências estaduais, não se desconsidera nem a relevância dos entes reguladores municipais nem a própria participação dos municípios no processo regulatório. Entretanto, há dificuldades para o exercício da atividade regulatória por ente próprio na maioria dos municípios da região Nordeste.

A investigação realizada não se encerra neste trabalho, ao contrário, suscita elementos para amplo debate que se inicia no país, sobretudo em virtude do estabelecimento dos marcos regulatórios subnacionais. Embora esta lei tenha trazido avanços na institucionalidade do setor, os marcos regulatórios subnacionais e sua efetiva implementação é que darão identidade à regulação, pois a lei estabelece somente diretrizes gerais.

Considerando ainda a importância destes marcos, as escolhas iniciais do poder executivo é que farão avançar a regulação, sobretudo em relação aos atores responsáveis pela concepção do modelo regulatório e do desenho da agência, ao perfil dos dirigentes indicados para estas entidades, à capacidade dos quadros técnicos e à disponibilidade orçamentária para início das atividades regulatórias.

Assim, ante os diferentes aspectos abordados nesta pesquisa, entende-se que no desenvolvimento da regulação setorial devem ser consideradas as seguintes diretrizes:

Gradatividade: A falta de cultura regulatória do setor e de quadros técnicos com conhecimento específico na área, além da legislação subnacional se encontrar em fase de concepção, exigem gradatividade na implantação da atividade regulatória.

Sustentabilidade da atividade regulatória: A regulação dever ser custeada com recursos dos próprios usuários, desde que não onerem de maneira abusiva as tarifas, tornando a atividade independente dos recursos orçamentários do titular dos 
serviços. Ademais, o conceito de sustentabilidade da atividade regulatória deve ser entendido de forma mais ampla, abrangendo não só os aspectos financeiros, mas também as capacidades técnica e institucional do ente regulador para executar as obrigações previstas no marco setorial.

Aproveitamento das capacidades instaladas: As agências reguladoras devem identificar formas de atuação dos sistemas de regulação intersetorial no sentido de efetivar parcerias para a regulação dos serviços de água e esgoto. Assim, o aproveitamento das capacidades técnicas e institucionais já existentes, com reconhecimento dos limites e das fragilidades operacionais de cada regulador intersetorial, contribuirá para priorização de ações que fortaleçam a regulação do setor. Diante das dificuldades de construção desta parceria intersetorial, propõe-se adoção de estratégia mediante modelo de cooperação baseado no estabelecimento gradual de mecanismos de diálogo e comunicação entre os vários reguladores.

Modelos regulatórios: Os modelos de regulação devem ser adaptáveis às diferentes realidades político-institucionais e administrativas, não havendo modelo ideal ou superioridade entre os vários arranjos. Assim, diante dos arranjos propostos, cabe, pois, identificar o mais adequado à realidade concreta e a melhor combinação de instrumentos institucionais e operacionais.

Fortalecimento institucional: A busca do fortalecimento institucional das agências reguladoras deve ser vista como meta permanente mediante ações de transparência, divisão de atribuições entre poder concedente e regulador, capacitação do quadro de pessoal, respeito às decisões regulatórias, entre outros.

Para finalizar, no contexto desta pesquisa, os subsídios advindos da literatura, da discussão com os reguladores setoriais e da experiência do autor podem contribuir para a regulação na região. Não obstante ser a pesquisa de caráter regional, as contribuiçð̃es apresentadas não se limitam ao Nordeste, e podem se ampliar para a discussão sobre a regulação em outras regiões.

Desta forma, é preciso consolidar a regulação e seus entes, pois com a plenitude desta atividade se poderá contribuir efetivamente para a universalização da prestação dos serviços de água e esgoto no Brasil. 


\section{RECOMENDAÇÕES}

Os desafios do setor de saneamento quanto à construção de uma regulação independente nos termos da Lei $\mathrm{n}^{\circ} 11.445 / 2007$ impõem demandas de pesquisas no campo acadêmico.

Entre os estudos necessários para complementação de lacunas no campo do conhecimento institucional do setor, recomendam-se os seguintes temas:

1. Regulação de empresas estatais e sociedades de economia mista de saneamento básico na América Latina.

Diferentes pesquisas desenvolvidas sobre regulação abordam o comportamento do setor quando operado por empresas privadas, entretanto, na realidade latino-americana há forte participação estatal na prestação dos serviços. Este contexto demanda pesquisa comparativa entre os diversos modelos regulatórios aplicados no Brasil e nos demais países da região, no intuito de identificar os desafios postos para este tipo de regulação, os incentivos e os instrumentos adotados pelos diferentes reguladores e os marcos setoriais estabelecidos.

2. Regulação da prestação dos serviços de água e esgoto por consórcios.

No Brasil é reportada a existência de consórcios de municípios para gestão de bacias hidrográficas e de sistemas para disposição e tratamento de resíduos sólidos, compra de insumos, entre outros. No entanto, não há experiência concreta de regulação da prestação dos serviços de água e esgoto por consórcio. Neste sentido, sugere-se desenvolver pesquisa para análise da viabilidade de regulação por esta modalidade, que discuta os entraves legais e operacionais para sua consecução, e forneça subsídios para montagem de modelos institucionais viáveis.

3. Normatização do setor de saneamento básico.

De acordo com o disposto no art. 23 da Lei $n^{\circ} 11.445 / 2007$, há um conjunto de normas a serem elaboradas, principalmente relacionadas aos aspectos econômicofinanceiros da regulação da prestação dos serviços de água e esgoto. Portanto, tornase necessária a discussão da base teórica, da legislação e dos métodos que comporão estes regulamentos, de forma a serem exequíveis às características do modelo de prestação dos serviços do país e às particularidades locais e regionais. 


\section{REFERÊNCIAS}

ABICALIL M. T. Uma nova agenda para o saneamento. In: ABICALIL M. T. et al. (Coord.). $O$ pensamento do setor de saneamento no Brasil: perspectivas futuras. Brasília: PMSS, 2002. p. 115-35.

AESBE - ASSOCIAÇÃO DAS EMPRESAS DE SANEAMENTO BÁSICO ESTADUAIS. Financiamento de investimentos em saneamento básico. Brasília, DF, 2006.

ALAGOAS. Lei $n^{\circ}$ 6.267, de 20 de setembro de 2001. Institui a Agência Reguladora de Serviços Públicos do Estado de Alagoas - ARSAL, e dá outras providências. Disponivel em:

http://www.arsal.al.gov.br/legba/bancodemidia/arquivos/lei_6267.pdf $>$. Acesso em: 4 dez. 2007.

ANATEL - AGÊNCIA NACIONAL DE TELECOMUNICAÇÕES. Regimento interno da ANATEL. Brasília: ANATEL, 2001. Disponível em < http://www.anatel.gov.br/Portal/documentos/biblioteca/resolucao/2001/anexo_res_27 0_2001.pdf?numeroPublicacao $=28626$ \&assuntoPublicacao $=$ Regimento $\% 20$ Interno $\%$ 20da\%20Anatel\&caminhoRel=Cidadao-Interação\%20com\%20a\%20SociedadeConsultas\%20à\%20Sociedade>. Acesso em: 12 nov. 2007.

ANATEL - AGÊNCIA NACIONAL DE TELECOMUNICAÇÕES. Plano geral de metas da qualidade para o serviço telefônico fixo comutado. Brasília: ANATEL, 2003.

Disponível

em

$<$ http://www.anatel.gov.br/Portal/documentos/biblioteca/contrato/concessao/novos/p gmq 2006.pdf?numeroPublicacao $=56726 \&$ assuntoPublicacao $=$ PLANO $\% 20$ GERAL \%20DE\%20METAS\%20DA\%20QUALIDADE\%20PARA\%200\%20SERVIÇO\%2 0TELEFÔNICO\&caminhoRel=Cidadao-Fiscalização-Apresentação>. Acesso em: 27 set. 2007. 
ANEEL - AGÊNCIA NACIONAL DE ENERGIA ELÉTRICA. Resolução ANEEL $n^{\circ} 24$, de 27 de janeiro de 2000. Estabelece as disposições relativas à continuidade da distribuição de energia elétrica às unidades consumidoras. Diário Oficial da União, Brasília, DF, 25 jan. 2006. Seção 1, p. 54, v. 143, n. 18.

ANP - AGÊNCIA NACIONAL DO PETRÓLEO. Portaria $n^{\circ} 104$, de 8 de julho de 2002. Estabelece a especificação do gás natural, de origem nacional ou importada, a ser comercializado em todo o território nacional. Diário Oficial da União, Brasília, DF, 9 jul. 2002.

ANTT - AGÊNCIA NACIONAL DE TRANSPORTES TERRESTRES. Resolução $\mathrm{n}^{\circ} 1.159$, de 5 de outubro de 2005. Disciplina os indicadores de produtividade e qualidade a serem aplicados na avaliação da prestação dos serviços regulares do transporte rodoviário interestadual e internacional coletivo de passageiros. Diário Oficial da União, Brasilia, DF, 13 out. 2005.

ARAGÃO, A. S. Regulação da economia: conceito e características contemporâneas. In: PECI, A. (Org.). Regulação no Brasil: desenho, governança e avaliação. São Paulo: Atlas, 2007. p. 31-71.

ARAÚJO, H. C.; PIRES, J. C. L. Regulação e arbitragem nos setores de serviços públicos no Brasil: problemas e possibilidades. Revista de Administração Pública. Rio de Janeiro, v. 34, n. 5, p. 9-28, set./out. 2000.

ARAÚJO, R. A. Regulação da prestação de serviços de saneamento básico abastecimento de água e esgotamento sanitário. In: IPEA. Infra-estrutura: perspectivas de reorganização; saneamento. Brasília: IPEA, 1999. p. 47-74. Disponível em $<\mathrm{http}$ //www.ipea.gov.br/pub/infraestrutura/saneamento/san_parte2.pdf $>$. Acesso em: 29 jun. 2006. 
ARCE - AGÊNCIA REGULADORA DE SERVIÇOS PÚBLICOS DELEGADOS DO ESTADO DO CEARÁ. Resolução ARCE n 24, de 16 de agosto de 2001. Disciplina a qualidade da água e de esgotos na prestação dos serviços de abastecimento de água e esgotamento sanitário. Fortaleza, CE, 2001.

ARCE - AGÊNCIA REGULADORA DE SERVIÇOS PÚBLICOS DELEGADOS DO ESTADO DO CEARÁ. Resolução ARCE n 69, de 24 de agosto de 2006. Disciplina a aplicação de penalidades por irregularidades na prestação do serviço público de abastecimento de água e esgotamento sanitário de Juazeiro do Norte. Fortaleza, CE, 2006.

ARCE - AGÊNCIA REGULADORA DE SERVIÇOS PÚBLICOS DELEGADOS DO ESTADO DO CEARÁ. Disponível em < http://www.arce.ce.gov.br $>$. Acesso em: 4 dez. 2007.

ARRETCHE, M. T. S. Política nacional de saneamento: a reestruturação das companhias estaduais. In: IPEA. Infra-estrutura: perspectivas de reorganização; saneamento. Brasília: IPEA, 1999. p. 75-106. Disponível em $<$ http://www.ipea.gov.br/pub/infraestrutura/saneamento/san_parte3.pdf $>$. Acesso em: 4 ago. 2006.

ARPE - AGÊNCIA DE REGULAÇÃO DE PERNAMBUCO. Resolução nº 4, de 30 de maio de 2007. Estabelece condições gerais para fiscalização técnico-operacional dos serviços públicos de distribuição d'água e de esgotamento sanitário, pela Companhia Pernambucana de Saneamento - Compesa, em todo o Estado de Pernambuco, e dá outras providências. Recife, PE, 2007a

ARPE - AGÊNCIA DE REGULAÇÃO DE PERNAMBUCO. Ata da $1^{\mathrm{a}}$ audiência pública de saneamento, realizada pela agência de regulação dos serviços públicos delegados do estado de Pernambuco - ARPE, no dia 7 de agosto de 2007. Recife, PE, 2007b. 
ARPE - AGÊNCIA DE REGULAÇÃO DE PERNAMBUCO. Disponível em < http://www.arpe.pe.gov.br>. Acesso em: 4 dez. 2007c.

\section{ARSAL - AGÊNCIA REGULADORA DE SERVIÇOS PÚBLICOS DO ESTADO}

DE ALAGOAS. Minuta do regulamento dos serviços de saneamento do estado de Alagoas. Disponível em < http://www.arsal.al.gov.br/servicos/saneamento/arquivos/minuta_regulamento.pdf >. Acesso em: 4 dez. 2007a.

ARSAL - AGÊNCIA REGULADORA DE SERVIÇOS PÚBLICOS DO ESTADO DE ALAGOAS. Minuta de contrato de concessão da prestação de serviços públicos de abastecimento de água e esgotamento sanitário. Disponível em < http://www.arsal.al.gov.br/servicos/saneamento/arquivos/minuta_contrato_concessao .pdf $>$. Acesso em: 4 dez. 2007b.

ARSAL - AGÊNCIA REGULADORA DE SERVIÇOS PÚBLICOS DO ESTADO DE ALAGOAS. Minuta do convênio de delegação de poderes e de cooperação técnica que entre si celebram o município e a agência reguladora de serviços públicos do estado de Alagoas. Disponível em < http://www.arsal.al.gov.br/servicos/saneamento/arquivos/minuta_convenio_prefeitur as.pdf $>$. Acesso em: 4 dez. 2007c.

ARSAL - AGÊNCIA REGULADORA DE SERVIÇOS PÚBLICOS DO ESTADO DE ALAGOAS. Disponível em <http://www.arsal.al.gov.br>. Acesso em: 4 dez. 2007d.

ARSBAN - AGÊNCIA REGULADORA DE SERVIÇOS DE SANEAMENTO BÁSICO DO MUNICÍPIO DE NATAL. Disponível em < http://www.natal.rn.gov.br/arsban/>. Acesso em: 4 dez. 2007.

ARPB - AGÊNCIA DE REGULAÇÃO DO ESTADO DA PARAÍBA. Disponível em < http://www.arpb.pb.gov.br>. Acesso em: 4 dez. 2007. 
ASSIS, J. B. L. ASSUSSA: um projeto possível. In: Congresso Brasileiro de Regulação (ABAR), 5, 2007, Recife, Pernambuco. Anais ... Alagoas: ABAR, CDROM, 2007.

BAKKER, K. J. Paying for water: water pricing and equity in England and Wales. Transactions of the Institute of British Geographers, v. 26, n. 2, p. 143-164, Jun. 2001.

BARCELLOS, C. A lenda urbana sobre internações devidas à falta de saneamento. Cad. Saúde Pública, Rio de Janeiro, v. 21, n. 4, p.996-997, ago. 2005.

BLACKMAN, C. R. Universal service: obligation or opportunitty? Telecommunications Policy, v. 19, n. 3, p. 171-76, 1995.

BORENSTEIN, C. R. Regulação em setores de infra-estrutura: a sociedade no controle externo das organizações. Revista de Administração Pública, Rio de Janeiro, v. 34, n. 5, p. 47-59, set./out. 2000.

BRASIL. Decreto n. ${ }^{\circ} 24.643$, de 10 de julho de 1934. Decreta o Código das Águas. Rio de Janeiro, RJ.

BRASIL. Decreto $n^{0} 79.367$, de 9 de março de 1977. Dispõe sobre normas e o padrão de potabilidade de água $\mathrm{e}$ dá outras providências. Disponível em: $<$ https://www.presidencia.gov.br/casacivil/site/static/le.htm>. Acesso em: 28 jun. 2006.

BRASIL. Lei n. ${ }^{\circ} 6.938$, de 31 de agosto de 1981. Dispõe sobre a Política Nacional do Meio Ambiente, seus fins e mecanismos de formulação e aplicação, e dá outras providências. Diário Oficial da União, Brasília, DF, 2 set. 1981.

BRASIL. Constituição (1998). Constituição da República Federativa do Brasil. Brasília, DF: Senado, 1988. 
BRASIL. Lei n. $^{\circ} 8.078$, de 11 de setembro de 1990 . Dispõe sobre a proteção do consumidor e dá outras providências. Diário Oficial da União, Brasília, DF, 12 set. 1990a.

BRASIL. Lei n. ${ }^{\circ} 8.080$, de 19 de setembro de 1990. Dispõe sobre as condições para a promoção, proteção e recuperação da saúde, a organização e o funcionamento dos serviços correspondentes e dá outras providências. Diário Oficial da União, Brasília, DF, 20 set. 1990b. p. 018055.

BRASIL. Lei n. ${ }^{\circ} 8.987$, de 13 de fevereiro de 1995. Dispõe sobre o regime de concessão e permissão da prestação de serviços públicos previsto no art. 175 da Constituição Federal, e dá outras providências. Brasília, DF, 1995a.

BRASIL. Ministério do Planejamento e Orçamento. Secretaria de Política Urbana. Regulação da prestação de serviços de saneamento; análise comparada da legislação internacional. Brasília, DF. 1995 b.

BRASIL. Lei n. ${ }^{\circ}$ 9.433, de 8 de janeiro de 1997. Institui a Política Nacional de Recursos Hídricos, cria o Sistema Nacional de Gerenciamento de Recursos Hídricos, regulamenta o inciso XIX do art. 21 da Constituição Federal, e altera o art. $1^{\circ}$ da Lei $\mathrm{n}^{\circ} 8.001$, de 13 de março de 1990 , que modificou a Lei $\mathrm{n}^{\circ} 7.990$, de 28 de dezembro de 1989. Diário Oficial da União, Brasília, DF, 9 jan. 1997a.

BRASIL. Lei n. ${ }^{\circ}$ 9.472, de 16 de julho de 1997. Dispõe sobre a organização dos serviços de telecomunicações, a criação e funcionamento de um órgão regulador e outros aspectos institucionais, nos termos da Emenda Constitucional n 8, de 1995. Diário Oficial da União, Brasília, DF, 11 jul. 1997b.

BRASIL. Lei n. ${ }^{\circ}$ 9.998, de 16 de agosto de 2000. Institui o Fundo de Universalização dos Serviços de Telecomunicações. Diário Oficial da União, Brasília, DF, 11 ago. 2000. 
BRASIL. Lei n. ${ }^{\circ} 10.257$, de 19 de julho de 2001. Regulamenta os arts. 182 e 183 da Constituição Federal, estabelece diretrizes gerais da política urbana e dá outras providências. Diário Oficial da União, Brasília, DF, 11 jul. 2001.

BRASIL. Ministério das Cidades. Secretaria Nacional de Saneamento Ambiental. Dimensionamento das necessidades de investimento para a universalização dos serviços de abastecimento de água e de coleta e tratamento de esgotos sanitários no Brasil. Brasília, DF, 2003

BRASIL. Ministério da Saúde. Organização Pan-Americana da Saúde. Avaliação de impacto na saúde das ações de saneamento: marco conceitual e estratégia metodológica. Brasília, DF, 2004a.

BRASIL. Ministério da Saúde. Portaria $n^{0}$ 518, de 25 de março de 2004b. Estabelece os procedimentos e responsabilidades ao controle e vigilância da qualidade da água para consumo humano e seu padrão de potabilidade, e dá outras providências. Disponível em: <http://dtr2001.saude.gov.br/sas/PORTARIAS/Port2004/GM/GM518.htm>. Acesso em: 26 jun. 2006.

BRASIL. Decreto $\mathrm{n}^{0}$ 5.440, de 4 de maio de 2005. Estabelece definições e procedimentos sobre o controle da qualidade da água de sistemas de abastecimento e institui mecanismos e instrumentos para divulgação de informação ao consumidor sobre a qualidade da água para consumo humano. Disponível em: $<$ https://www.planalto.gov.br/ccivil_03/_Ato2004-2006/2005/Decreto/D5440.htm>. Acesso em: 26 jun. 2006.

BRASIL. Ministério da Saúde. Vigilância em saúde: dados e indicadores selecionados 2005. Brasília; 2006. Disponível em < http://portal.saude.gov.br/portal/arquivos/pdf/indicadores_2006.pdf $>$. Acesso em: 18 jun. 2007. 
BRASIL. Lei $\mathrm{n}^{\circ} 11.445$, de 5 de janeiro de 2007. Estabelece diretrizes nacionais para o saneamento básico; altera as Leis nos 6.766, de 19 de dezembro de 1979, 8.036, de 11 de maio de 1990, 8.666, de 21 de junho de 1993, 8.987, de 13 de fevereiro de 1995; revoga a Lei $n^{0} 6.528$, de 11 de maio de 1978; e dá outras providências. Diário Oficial da União, Brasília, DF, 8 jan. 2007a.

BRASIL. Ministério das Cidades. Secretaria Nacional de Saneamento Ambiental. Investimentos federais em saneamento. Brasília, DF, 2007b.

BRITTO, A. L. N. P. A Regulação dos serviços de saneamento no Brasil: perspectiva histórica, contexto atual e novas exigências de uma regulação pública. In: ENCONTRO NACIONAL DA ANPUR, 9., 2001, Rio de Janeiro. Anais ... Rio de Janeiro: ANPUR, 2001. p. 1080-93.

BURNS, P.; CRAWFORD, I.; DILNOT, A. Regulation and redistribution in utilities. Fiscal Studies, v. 16, n. 4, p. 1-22, Nov. 1995.

CEARÁ. Lei $\mathrm{n}^{\circ}$ 12.786, de 30 de dezembro de 1997. Institui a Agência Reguladora de Serviços Públicos Delegados do Estado do Ceará - ARCE, e dá outras providências. <Disponível em: http://www.arce.ce.gov.br/legislacao.asp?id=221>. Acesso em: 26 jun. 2006.

CEARÁ. Convênio $n^{\circ} 1$, de $1^{\circ}$ de setembro de 2001. Convênio que entre si celebram a Agência Reguladora de Serviços Públicos Delegados do Estado do Ceará - ARCE, a Secretaria da Infra-Estrutura do Estado do Ceará - SEINFRA e a Companhia de Água e Esgoto do Ceará- CAGECE, para a transferência de atribuições de auditoria da SEINFRA sobre a CAGECE. Disponível em: <Disponível em: http://www.arce.ce.gov.br/legislacao.asp?id=224>. Acesso em: 26 jun. 2006.

CONFORTO, G. Descentralização e regulação da gestão de serviços públicos. Revista de Administração Pública, Rio de Janeiro, v. 32, n. 1, p. 27-40, jan./fev. 1998. 
CONFORTO, G. A regulação e a titularidade dos serviços de abastecimento de água e esgotamento sanitário no Brasil. Revista de Administração Pública, Rio de Janeiro, v. 34, n. 5, p. 165-80, set./out. 2000.

CORREA, P. et al. Regulatory governance in infrastructure industries assessment and measurement of Brazilian regulators. Washington DC: World Bank, 2006.

COWAN, S. Alternative approaches to regulation: an economic analysis of lighthanded regulation. Paper prepared for the Australian Competition and Consumer Commission Regulatory Conference. Surfers' Paradise, Jul. 2007.

DANTAS, D. C. C. A ouvidoria e a informação como instrumentos de controle social: a experiência da ARCE. In: GALVÃO JR., A. C.; XIMENES, M. M. A. F. Regulação, controle social da prestação dos serviços de água e esgoto. Fortaleza: ABAR, 2007. p. 177-192.

DI PIETRO, M. S. Z. Limites da função reguladora das agências diante do princípio da legalidade. In: .Direito regulatório: temas polêmicos. Belo Horizonte: Fórum, 2004. p. 19-50.

EHRHARDT, D. et al. Economic regulation of urban water and sanitation services: some practical lessons. Washington, DC.: World Bank, 2007. 30 p. Disponível em http://wwwwds.worldbank.org/external/default/WDSContentServer/WDSP/IB/2007/06/04/0000 20953_20070604154231/Rendered/PDF/399110Economic0regulation0WS901PUBL IC1.pdf. Acesso em: 29 jun. 2007.

FARIA, S. A.; FARIA, R. C. Cenários e perspectivas para o setor de saneamento e sua interface com os recursos hídricos. Eng. San. Ambient., Rio de Janeiro, v. 9, n. 3, p. 202-210, jul./set. 2004. 
FARINA, E. M. M. Q.; AZEVEDO, P. F.; PICCHETTI, P. A reestruturação dos setores de infra-estrutura e a definição dos marcos regulatórios: princípios gerais, características e problemas. In: IPEA. Infra-estrutura: perspectivas de reorganização, regulação. Brasília: IPEA, 1997. v.1, p. 43-80. Disponível em $<$ http://www.ipea.gov.br/pub/infraestrutura/regulacao/parte2.pdf $>$. Acesso em: 25 maio 2007.

FOSTER, V. Ten years of water service reform in Latin America: toward an AngloFrench model. Washington, DC: World Bank, 2005. 26 p. Disponível em http://www-

wds.worldbank.org/external/default/WDSContentServer/WDSP/IB/2005/04/13/0000 90341_20050413100040/Rendered/PDF/320270WSSServiceReform.pdf. Acesso em: 29 jun. 2007.

FREY, K. Políticas públicas: um debate conceitual e reflexões referentes à prática da análise de políticas públicas no Brasil. Brasília: IPEA, 2000. p. 211-259. Disponível em: <http://www.ipea.gov.br/pub/ppp/ppp21/Parte5.pdf>. Acesso em: 6 maio 2006.

GAESE, H. Degradation factors in a risk-prone area: the semiarid Northeast of Brazil. In: GAISER et al. (Ed.). Global change and regional impacts. New York: Springer, 2003. p. 125-133.

GALVÃO JUNIOR, A. C. et al. Regulação: procedimentos de fiscalização em sistemas de abastecimento de água. Fortaleza: Expressão Gráfica e Editora/ARCE, 2006.

GALVÃO JR., A. C.; PAGANINI, W. S. Estado da arte da regulação da prestação dos serviços de água e esgoto no Brasil. In: Congreso de la Asociación Interamericana de Ingeniería Sanitaria Y Ambiental (AIDIS), 30, 2006, Punta del Leste, Uruguay. Anais ...Punta del Leste: AIDIS, CD-ROM, 2006. 
GALVÃo JUNIOR, A. C. G.; XIMENES, M. M. A. F. Desafios para os conselhos de saneamento básico. In: . Regulação, controle social da prestação dos serviços de água e esgoto. Fortaleza: ABAR, 2007. p. 69-93.

GALVÃO JUNIOR, A. C.; TUROLLA, F. A.; PAGANINI, W. S. Viabilidade da Regulação Subnacional dos Serviços de Abastecimento de Água e Esgotamento Sanitário sob a Lei 11.445/2007. Eng Sanit Ambient., Rio de Janeiro, 2008. No prelo.

GHARAM, S.; CORNFORD, J.; MARVIN, S. The socio-economic benefits of a universal telephone network. Telecommunications Policy, v. 20, n. 1, p. 3-10, 1996.

GIL, A. C. Como elaborar projetos de pesquisa. 4. ed. São Paulo: Atlas, 2002.

GLEICK, P. H. The Human Right of Water. Water Policy, v. 1, n. 1, p. 487-503, 1999.

GOMES FILHO, J. F. Crianças e adolescentes no semi-árido brasileiro. Recife: Unicef, 2003.

GROOM, E.; HALPERN, J.; EHRHARDT, D. Explanatory notes on key topics in the regulation of water and sanitation services. Washington, DC: World Bank, 2006. $84 \quad$ p. $\quad$ Disponível em $<$ http://wwwwds.worldbank.org/external/default/WDSContentServer/WDSP/IB/2006/09/29/0003 10607_20060929133630/Rendered/PDF/375290Explanatory0notes0WSS601PUBLI C1.pdf>. Acesso em: 29 jun. 2007.

HAGG, T. G. P. Theories on the economics of regulation: a survey of the literature from European perspective. European Journal of Law and Economics, n. 4, p. 337-70, dez. 1997. 
HELlER, L.; COLOSIMO, E. A.; ANTUNES, C. M. F. Environmental sanitation conditions and health impacts: a case-control study. Rev Soc Bras Med Trop, v. 36, n. 1, p. 41-50, jan./fev. 2003.

HELlER, L.; NASCIMENTO, N. O. Pesquisa e desenvolvimento na área de saneamento no Brasil: necessidades e tendências. Eng Sanit Ambient., Rio de Janeiro, v. 10, n. 1, p. 24-35, jan./mar. 2005.

HELLER et al. Políticas públicas de saneamento: considerações sobre um enfoque metodológico para a comparação de diferentes modelos de gestão. In: Congreso Brasileiro de Engenharia Sanitária e Ambiental, 24, 2007, Belo Horizonte. Anais... Rio de Janeiro: ABES, CD-ROM, 2007.

HESPANHOL, I. Água e saneamento básico, uma visão realista. In: REBOUÇAS et al. (Coord.). Águas doces no Brasil. São Paulo: Escrituras Editora, 1999. p. 249303.

HOLT, L. Utility service quality - telecommunications, electricity, water. Utilities Policy, n. 13, p. 189-200, Sep. 2005.

HUNT, E. K. História do pensamento econômico, uma perspectiva crítica. 2. ed. Rio de Janeiro: Elsevier, 2005.

HUTTON, G.; HALLER, L. Evaluation of the costs and benefits of water and sanitation Improvements at the global level. Genebra, Suíça: Organização Mundial da Saúde, 2004.

IBGE - Instituto Brasileiro de Geografia e Estatística. Censo Demográfico 2000. Rio de Janeiro: IBGE; 2001.

IBGE - Instituto Brasileiro de Geografia e Estatística. Pesquisa nacional por amostra de domicílios: 2001. Rio de Janeiro, 2002. 
IBGE - Instituto Brasileiro de Geografia e Estatística. Contas Regionais do Brasil 2003a. Disponível em $<\mathrm{http}: / /$ www.ibge.gov.br $>$. Acesso em $1^{\circ} \mathrm{dez}$. 2007b.

IBGE - Instituto Brasileiro de Geografia e Estatística. Estatísticas do século XX. Rio de Janeiro, 2003b.

IBGE - Instituto Brasileiro de Geografia e Estatística. Pesquisa nacional por amostra de domicílios: 2005. Rio de Janeiro, 2006.

IBGE - Instituto Brasileiro de Geografia e Estatística. Contagem 2007. Rio de Janeiro, 2007a. Disponível em <http://www.ibge.gov.br>. Acesso em $1^{\circ} \mathrm{dez} .2007$.

IBGE - Instituto Brasileiro de Geografia e Estatística. Perfil dos municípios brasileiros: 2006. Rio de Janeiro, 2007b.

IESP - Instituto de Economia do Setor Público. Proposta de regulamentação da prestação de serviços de saneamento. Brasília: Ministério do Planejamento e Orçamento. Secretaria de Política Urbana/IPEA, 1995. 168 p. (Série Modernização do Setor de Saneamento, 5).

INFURB - Núcleo de Pesquisas em Informações Urbanas da Universidade de São Paulo. Fundamentos e proposta de ordenamento institucional. Brasília: Ministério do Planejamento e Orçamento. Secretaria de Política Urbana/IPEA, 1995. (Série Modernização do Setor Saneamento, 1).

INSTITUTO TRATA BRASIL. Trata Brasil: saneamento e saúde. NERI, M. C. (Coord.). Rio de Janeiro: FGV/IBRE, CPS, 2007.

JONES, A. Social responsibility and the utilities. Journal of Business and Ethics, n. 34, p. 219-229, 2001. 
JORDAN, J. L. Introduction to water: Economic concepts, water supply and water use. Georgia, USA: Department of Agricultural \& Applied Economics, 1998. (Georgia Water Series, Issue 1, $\mathrm{n}^{\circ}$ 98-13).

JOURAVLEV, A. Regulación de la industria de agua potable: necesidades de información y regulación estructural. Santiago do Chile: CEPAL, 2001a. v. 1. Disponível em:

http://www.cepal.org/publicaciones/xml/0/9380/lcl1671add.1PE.pdf $>$. Acesso em: 8 abr. 2007.

JOURAVLEV, A. Regulación de la industria de agua potable: regulación de las conductas. Santiago do Chile: CEPAL, 2001b. v. 2. Disponível em: < http://www.cepal.org/publicaciones/xml/0/9380/lcl1671PE.pdf $>$. Acesso em: 8 abr. 2007.

JOURAVLEV, A. Acesso a la información: una tarea pendiente para la regulación latinoamericana. Santiago do Chile: CEPAL, 2003. Disponível em: < http://www.cra.gov.co/portal/www/resources/nxp_ajouravlev.pdf $>$. Acesso em: 5 set. 2006.

JOURAVLEV, A. Drinking water supply and sanitation services on the threshold of the XXI century. Santiago do Chile: CEPAL, 2004. Disponível em: < http://www.cepal.org/publicaciones/xml/9/19539/lcl2169i.pdf $>$. Acesso em: 5 set. 2006.

JUAZEIRO DO NORTE. Lei ${ }^{\circ} 2.761$, de 10 de novembro de 2003. Altera a Lei Municipal $n^{\circ} 2759$, de 27.10.2003, que dispõe sobre o regime de concessão da prestação dos serviços públicos de captação, adução, tratamento, reservação e distribuição de água e de coleta, transporte, tratamento e disposição final de esgotos sanitários do município de Juazeiro do Norte e adota outras providências. Disponível em: <http://www.arce.ce.gov.br/legislacao.asp?id=1521>. Acesso em: 2 abr. 2007. 
KRUGMAN, P.; WELLS, R. Introdução à economia. Rio de Janeiro: Elsevier, 2007.

LAKATOS, E. V.; MARCONI, M. A. Fundamentos de metodologia científica. São Paulo: Atlas 1985.

LEE, T. R. Urban water management for better urban life in Latin America. Urban Water, v. 2, n.1, p. 71-78, Mar. 2000.

LIMA, U. M. A regulação dos serviços de saneamento básico no município de Natal. Palestra proferida no curso Regulação da prestação de serviços de água e esgoto. ABES/SP: $1^{\circ}$ set. 2006.

LINS, A. P. G. D. Regulação enquanto ferramenta de controle social no setor de saneamento. Estudo de caso: ARSAL . In: Congresso Brasileiro de Regulação (ABAR), 5, 2007, Recife, Pernambuco. Anais ... Alagoas: ABAR, CD-ROM, 2007.

LUNA, M. A. S. A questão das perdas de água no estado de Pernambuco. In: Congresso Brasileiro de Regulação (ABAR), 5, 2007, Recife, Pernambuco. Anais ... Alagoas: ABAR, CD-ROM, 2007.

MAJONE, G. Regulating Europe. New York: Routledge, 1996.

MAJONE, G. Do Estado positivo ao Estado regulador: causas e consequiências da mudança no modo de governança. In: MATOS, P.T.L. et al. (Orgs.). Regulação econômica e democracia: o debate europeu. São Paulo: Singular, 2006. p. 53-85.

MARQUES NETO, F. A. Agências reguladoras independentes: fundamentos e seu regime jurídico. Belo Horizonte: Fórum, 2005.

MARTINS, R. C.; FELICIDADE, N. Limitações da abordagem neoclássica como suporte teórico para gestão de recursos hídricos no Brasil. In: FELICIDADE, N.; 
MARTINS, R. C.; LEME, A. A. (Orgs.). Recursos hídricos no Brasil. São Carlos: RiMa, 2001. p. 17-37.

MCIDADES - Ministério das Cidades. Sistema nacional sobre saneamento: diagnóstico dos serviços de água e esgotos - 2005. Brasília: MCIDADES. SNSA, 2006.

MELLO, L. A. O problema econômico dos serviços de utilidade pública. São Paulo: Prefeitura Municipal de São Paulo, 1940.

MENDES, C. H. Reforma do estado e agências reguladoras: estabelecendo os parâmetros de discussão. In: SUNDFELD, C. A. (Org.). Direito administrativo e econômico. 2. ed. São Paulo: Malheiros, 2002. p. 99-139.

MENDES, C. H. et al. Poder Concedente e Marco Regulatório no Saneamento Básico. Cadernos Direito GV. Vol. 2, n. 2, Relatório de Pesquisa número 10, São Paulo, 2006.

MENDES, P. B. M. T. et al. Audiências públicas: limites e possibilidades nos processos decisórios. In: GALVÃO JR., A. C.; XIMENES, M. M. A. F (Edit.). Regulação, controle social da prestação dos serviços de água e esgoto. Fortaleza: ABAR, 2007. p. 115-143.

MINAYO, M. C. S. O desafio do conhecimento - pesquisa qualitativa em saúde. 8. ed. São Paulo: Hucitec, 2004.

MOITA, R. M. S. Regulação por incentivos: a universalização dos serviços de saneamento básico. 2003. Dissertação (Mestrado em Economia). Faculdade de Economia, Administração e Contabilidade, USP, São Paulo. 
MRE - Ministério das Relações Exteriores. Região Nordeste. Disponível em: < http://www.mre.gov.br/CDBRASIL/ITAMARATY/WEB/port/divpol/nordeste/regia o/apresent/index.htm>. Acesso em: 6 dez. 2007.

MUKAI, S. T. Da regulação. In: MUKAI, T. (Coord.). Saneamento básico: diretrizes gerais - comentários gerais à Lei 11.445 de 2007. Rio de Janeiro: Lumen Juris, 2007. p. 59-71.

NASCIMENTO, N. O.; HELLER, L. Ciência, tecnologia e inovação na interface entre as áreas de recursos hídricos e saneamento. Eng. San. Ambient., Rio de Janeiro, v. 10, n. 1, p. 36-48, jan./mar. 2005.

NATAL (Prefeitura Municipal). Lei $n^{\circ}$ 5.346, de 28 de dezembro de 2001. Cria a Agência Reguladora de Serviços de Saneamento Básico do Município de Natal ARSBAN, e dá outras providências. 2001a. Disponível em: $<$ http://www.abar.org.br>. Acesso em 12 jun. 2006.

NATAL (Prefeitura Municipal). Lei $\mathrm{n}^{\circ} 5.285$, de 25 de julho de 2001. Cria o Conselho Municipal de Saneamento Básico e estabelece outras disposições. $2001 \mathrm{~b}$.

NATAL, Contrato de concessão da prestação de serviços públicos de abastecimento de água e esgotamento sanitário. Natal, Rio Grande do Norte, 2002.

NAVES, R. Agências reguladoras: origens e perspectivas. In: FIGUEIREDO, M. (Org.). Direito e regulação: no Brasil e nos EUA. São Paulo: Malheiros, 2004. p. 123-134.

OFWAT - Water Services Regulation Authority. Market competition in the water and sewerage industries in England and Wales. Part one : water supply licensing. England: $\quad$ OFWAT, $2007 . \quad$. $\quad$ Disponível em $<$ http://www.ofwat.gov.uk/aptrix/ofwat/publish.nsf/AttachmentsByTitle/marketcomp 
_waterind_part1.pdf/\$FILE/marketcomp_waterind_part1.pdf $>$. Acesso em: $29 \mathrm{dez}$. 2007.

OGERA, R. C.; PHILIPPI JR., A. Gestão dos serviços de água e esgoto nos municípios de Campinas, Santo André, São José dos Campos e Santos, no período de 1996 a 2000. Eng. San. Ambient., Rio de Janeiro, v. 10, n. 1, p. 72-81, jan./mar. 2005.

OLIVEIRA, G.; FUJIWARA, T.; MACHADO, E. L. A experiência brasileira com agências reguladoras. In: SALGADO, L. H.; SEROA DA MOTTA, R. Marcos regulatórios no Brasil: o que foi feito e o que falta fazer. Rio de Janeiro: IPEA, 2005. p. 163-197.

OMS - Organização Mundial da Saúde. Fundo das Nações Unidas para a Criança UNICEF. Global water supply and sanitation assessment 2000 report. New York, USA, 2000.

OMS - Organização Mundial da Saúde. The world health report 2007: a safer future: global public health security in the 21 st century. Genebra, Suécia, 2007.

ONU - Organização das Nações Unidas. General comment $n^{\circ} 15$, de 20 de janeiro de 2003. Right to water. Genebra, Suíça, 2003.

ONU - Organização das Nações Unidas. Projeto do Milênio das Nações Unidas 2005. Investindo no Desenvolvimento: Um plano prático para atingir os Objetivos de Desenvolvimento do Milênio. Visão Geral. Nova Iorque, EUA, 2005.

ONU - Organização das Nações Unidas. The millennium development goals report 2007. Nova Iorque, EUA, 2007. 
PACHECO, R. S. Regulação no Brasil: desenho das agências e formas de controle. Revista de Administração Pública, Rio de Janeiro, v. 40, n. 4, p. 523-43, jul./ago. 2007.

PARAÍBA (Estado). Lei Estadual $n^{\circ} 7.033$ de 29 de novembro de 2001. Cria a Agência de Águas, Irrigação e Saneamento do Estado da Paraíba - AAGISA, e dá outras providências. $\quad$ Disponível em < http://www.semarh.pb.gov.br/legislacao\%20recursos\%20hidricos/lei7033.php>. Acesso em: 4 dez. 2007.

PARAÍBA (Estado). Lei Estadual $n^{\circ}{ }^{0} 7.843$, de $1^{\circ}$ de novembro de 2005. Dispõe sobre a estrutura e o funcionamento da Agência de Regulação do Estado da Paraíba ARPB, instituída pela Lei Complementar $n .^{\circ}$ 67, de 7 de julho de 2005, e dá outras providências. Disponível em < http://www.arpb.pb.gov.br/pdf/lei_7843_021105_Reestrutura.pdf $>$. Acesso em: 4 dez. 2007.

PARLATORE, A. C. Privatização do setor de saneamento no Brasil. In: PINHEIRO, A. C.; KIICHIRO, F. (Eds.). A privatização no Brasil: o caso dos serviços de utilidade pública. Rio de Janeiro: BNDES, p. 281-320, 2000. Disponível em $<$ http://www.bndes.gov.br/conhecimento/ocde/ocde08.pdf $>$. Acesso em: 29 jun. 2006.

PATERSON, C.; DUNCAN, M.; CURTIS, T. Pro-poor sanitation technologies. Geoforum, v. 38, n. 5, p. 901-907, Set. 2007.

PECI, A. Regulação comparativa: uma (des)construção dos modelos regulatórios. In: PECI, A. (Org.). Regulação no Brasil: desenho, governança, avaliação. São Paulo: ATLAS, 2007. p. 72-92. 
PELTZMAN, S. A teoria da regulação depois de uma década de desregulação. In: MATTOS, P. et al. (Coord.). Regulação econômica e democracia: o debate norteamericano. São Paulo: Ed. 34, 2004. p. 81-127.

PENA, D. S.; ABICALIL, M. T. Saneamento: os desafios do setor e a política de saneamento. In: IPEA. Infra-estrutura: perspectivas de reorganização, saneamento. Brasília: IPEA, 1999. p. 107-137. Disponível em $<$ http://www.ipea.gov.br/pub/infraestrutura/saneamento/san_parte4.pdf $>$. Acesso em: 6 maio 2006.

PEREIRA, D. S. P.; JOHNSSON, R. M. F. Descentralização da gestão dos recursos hídricos em bacias nacionais no Brasil. Rega, Porto Alegre, v. 2, n. 1, p. 53-72, jan./jul. 2005.

PERNAMBUCO (Estado). Lei Estadual $n^{\circ}$ 12.524, de 30 de dezembro de 2003. Altera e consolida as disposições da Lei $n^{\circ} 12.126$, de 12 de dezembro de 2001, que cria a Agência de Regulação dos Serviços Públicos Delegados do Estado de Pernambuco - ARPE, e dá outras providências. Disponível em < http://www.arpe.pe.gov.br/pdf/lei_estadual_12524.PDF>. Acesso em: 4 dez. 2007.

PERNAMBUCO (Estado). Lei Estadual $\mathrm{n}^{\circ}$ 12.813, de 19 de maio de 2005. Disciplina a realização de audiências públicas previamente à autorização de aumentos nas tarifas ou preços praticados por empresas concessionárias de serviços públicos de titularidade do Estado de Pernambuco. . Disponível em $<$ http://www.arpe.pe.gov.br/pdf/lei_estadual_12813.PDF>. Acesso em: 4 dez. 2007.

PEROSA, P. T. Y. Regulação dos serviços de saneamento básico: aspectos conceituais e fatores intervenientes. 2002. 94 p. Dissertação (Mestrado em Saúde Pública). Faculdade de Saúde Pública, USP, São Paulo. 
PHILIPPI JR., A.; SILVEIRA, V. F. Saneamento ambiental e ecologia aplicada. In: PHILIPPI JR. et al. (Coord.). Curso de gestão ambiental. Barueri, SP: Manole; 2004. p.19-52.

PHILLIPS JR., C. F. The regulation of public utilities - theory and practice. Arlington, VA: Public Utilities Report, 1993.

PINHEIRO, A. C.; SADDI, J. Direito, economia e mercados. Rio de Janeiro: Elsevier, 2005.

PINTO, B. Regulamentação efetiva dos serviços de utilidade pública. Rio de Janeiro: Revista Forense, 1941.

PIRES, J. C. L.; GOLDSTEIN, A. Agências reguladoras brasileiras: avaliação e desafios. Revista do BNDES, Rio de Janeiro, v. 8, n. 16, p. 3-42, dez. 2001. Disponível em <http://www.bndes.gov.br/conhecimento/revista/rev1601.pdf $>$. Acesso em: 4 ago. 2006.

PIRES, J. C. L.; PICCININI, M. S. A regulação dos setores de infra-estrutura no Brasil. Rio de Janeiro: BNDES, 1999, p. 217-260. Disponível em $<\mathrm{http} / / /$ www.bndes.gov.br/conhecimento/livro/eco90_07.pdf $>$. Acesso em: 18 ago. 2006.

POSNER, R. A. Teorias da regulação econômica. In: MATTOS, P. et al. (Coord.). Regulação econômica e democracia: o debate norte-americano. São Paulo: Ed. 34, 2004. p. 49-80.

PRAGANA, R. B. et al. Papel das agências reguladoras na fiscalização da destinação dos resíduos provenientes dos serviços de saneamento básico - estudo de caso: estado de Pernambuco . In: Congresso Brasileiro de Regulação (ABAR), 5, 2007, Recife, Pernambuco. Anais ... Alagoas: ABAR, CD-ROM, 2007. 
REICH, N. A crise regulatória: ela existe e pode ser resolvida? In: MATOS, P.T.L. et al. (Orgs.). Regulação econômica e democracia: o debate europeu. São Paulo: Singular, 2006. p. 17-52.

REYNOLDS, L. Foundations of an institutional theory of regulation. Journal of Economic Issues, v. XV, n. 3, p. 641-656, Sep. 1981.

RIBEIRO, H. Saúde pública e meio ambiente: evolução do conhecimento e da prática, alguns aspectos éticos. Saúde e Sociedade, São Paulo, v. 13, n. 1, p. 70-80, jan./abr. 2004.

SALGADO, L. H. Agências reguladoras na experiência brasileira: um panorama do atual desenho institucional. Rio de Janeiro: IPEA, 2003. 52 p. Disponível em $<$ http://www.ipea.gov.br/pub/td/2003/td_0941.pdf>. Acesso em: 19 maio 2007.

SAPPINGTON, D. E. M. Principles of regulatory policy design. Washington, DC.: World Bank, 1994. 49 p. Disponível em <http://wwwwds.worldbank.org/external/default/WDSContentServer/WDSP/IB/1994/01/01/0000 09265_3961005201619/Rendered/PDF/multi0page.pdf $>$. Acesso em 19 maio 2007.

SAPPINGTON, D. E. M. Regulating service quality: a survey. Journal of Regulatory Economics, v. 27, n. 2, p. 124-154, 2005.

SEROA DA MOTTA, R. Questões regulatórias do setor de saneamento no Brasil. Rio de Janeiro: IPEA, 2004. 24 p. Disponível em < http://www.ipea.gov.br/sites/000/2/publicacoes/notastecnicas/notastecnicas5.pdf>. Acesso em: 19 maio 2007.

SEROA DA MOTTA, R. As opções de marco regulatório de saneamento no Brasil. Plenarium, Brasília, n. 3, p. 100-116, Set. 2006. 
SEROA DA MOTTA, R.; MOREIRA A. Efficiency and regulation in the sanitation sector in Brazil. Utilities Policy, v. 14, n. 3, p. 185-195, set. 2006.

SERRA, G. C. Questão urbana e participação no processo de decisão. In: PHILIPPI JR. et al (Coord.). Curso de gestão ambiental. Barueri, SP: Manole, 2004. p. 715735.

SILVA, A. M. A.; RESENDE, G. A importância do acesso aos serviços públicos na renda por habitante dos municípios nordestinos. Brasília: IPEA, 2005. 21 p. Disponível em <http://www.ipea.gov.br/pub/td/2005/td_1132.pdf >. Acesso em: 29 jun. 2006.

SILVA, R. T. Público e privado na oferta de infra-estrutura urbana no Brasil. In: Anuário Gedim 2002 (Cidades, serviços e cidadania). Programa Interdisciplinar Globalização Econômica e Direitos no Mercosul (Gedim), Unesco/MOST. Rio de Janeiro: Editora Lúmen Júris, 2002. p. 53-112.

SILVA, R. T. A regulação e o controle público da infra-estrutura e dos serviços urbanos no Brasil. In: DEÁK, C.; SCHIFFER, S.R. (Orgs.). O processo de urbanização no Brasil. São Paulo: Edusp, 2004. p. 261-312.

SILVA, R. T. Aspectos conceituais e teóricos. In: GALVÃO JR., A. C.; SILVA, A. C. Regulação, indicadores para a prestação dos serviços de água e esgoto. Fortaleza: ABAR, 2006, p. 29-53.

SILVA, A. C. Aplicação de indicadores para regulação da qualidade dos serviços de abastecimento de água (estudo de caso). In: Congresso Brasileiro de Engenharia Sanitária e Ambiental, 24, 2007, Belo Horizonte. Anais... Rio de Janeiro: ABES, CD-ROM, 2007. 
SILVA, R. T.; MACHADO, L. Serviços urbanos em rede e controle público do subsolo - novos desafios à gestão urbana. São Paulo Perspec., São Paulo, v. 15, n. 1, p. 102-111, jan./mar. 2001.

SOARES, S. R. A.; BERNARDES, R. S.; CORDEIRO NETTO, O. M. Relações entre saneamento, saúde pública e meio ambiente: elementos para formulação de um modelo de planejamento em saneamento. Cad. Saúde Pública, Rio de Janeiro, v. 18, n. 6, 1713-24, nov./dez., 2002.

STIGLER, G. J. A teoria da regulação econômica. In: MATTOS, P. et al. (Coord.). Regulação econômica e democracia: o debate norte-americano. São Paulo: Ed. 34, 2004. p. 23-48.

SUNDFELD, C. A. Introdução às agências reguladoras. In: . (Org.).

Direito administrativo e econômico. 2. ed. São Paulo: Malheiros, 2002. p. 17-38.

TAVARES, R. G. et al. A experiência da ARPE no monitoramento dos parâmetros cor, turbidez, cloro residual e coliformes totais - indicadores de qualidade da água tratada. In: Congresso Brasileiro de Regulação (ABAR), 5, 2007, Recife, Pernambuco. Anais ... Alagoas: ABAR, CD-ROM, 2007.

TEIXEIRA, J. C.; PUNGIRUM, M. E. M. C. Análise da associação entre saneamento e saúde nos países da América Latina e do Caribe, empregando dados secundários do banco de dados da Organização Pan-Americana de Saúde - OPAS. Rev. Bras. Epidemiol., São Paulo, v. 8, n. 4, p. 365-76, 2005.

TONETO JÚNIOR, R.; SAIANI, C. C. S. Restrições à expansão dos investimentos no saneamento básico brasileiro. Revista Econômica do Nordeste, Rio de Janeiro, v. 37, n. 4 , p. 572-591, out./dez. 2006.

TREBING, H. M. Regulation of industry: an institutional approach. Journal of Economic Issues, v. XXI, n. 4, p. 1707-1737, Dec. 1987. 
TRÉMOLET, S; HUNT, C. Taking account of the poor in water sector regulation. Washington, DC: World Bank, 2006. 75 p. Disponível em <http://wwwwds.worldbank.org/external/default/WDSContentServer/WDSP/IB/2006/10/05/0000 90341_20061005145018/Rendered/PDF/375340Poor0in0Water0sector0WN1101PU BLIC1.pdf>. Acesso em: 10 ago. 2007.

TUPPER, H. C.; RESENDE, M. Efficiency and regulatory issues in the Brazilian water and sewage sector: an empirical sudy. Utilities Policy, v. 12, p. 29-40, n. 1 , Mar. 2004.

TUROLlA, F. A. T. Política de saneamento: avanços recentes e opções futuras de políticas públicas. Brasília: IPEA, 2002. 26 p. Disponível em <http://www.ipea.gov.br/pub/td/2002/td_0922.pdf>. Acesso em: 6 maio 2006.

TUROLLA, F. A. T. Participação social na definição de tarifas. In: GALVÃO JR., A. C.; XIMENES, M. M. A. F. Regulação, controle social da prestação dos serviços de água e esgoto. Fortaleza: ABAR, 2007. p. 95-113.

TUROLLA, F. A.; OHIRA, T. H. Saneamento básico: experiência internacional e avaliação de propostas para o Brasil. São Paulo, SP: CNI, 2006.

VALLADÃO, A. Regime jurídico das águas e da indústria hidroelétrica. São Paulo: Prefeitura Municipal de São Paulo, 1941.

VARGAS, M. C. O negócio da água. São Paulo: Annablume, 2005.

VARGAS, M. C.; LEME, A.; LIMA, R. State, market and utilities provision: economic theory perspectives. Oxford: Prinwass, 2002. Disponível em < http://users.ox.ac.uk/ prinwass/PDFs/vargas.pdf $>$. Acesso em: 25 maio 2007. 
VINNARI, E. M. The economic regulation of publicly owned water utilities: The case of Finland. Utilities Policy, v. 14, p. 158-165, Set. 2006.

VISCUSI, W. K.; HARRINGTON JR., J. E.; VERNON, J. M. Economics of regulation and antitrust. $4^{\text {th }}$ ed. Cambridge, MA: MIT Press, 2005.

YILMAR, Y. A real alternative for regulation reform. Cato Policy Analysis, n. 303, Apr. 1998.

WILLAMS, J.; BORROWS, J.; DALY, S. Small water company regulations: choices for commissions. NARUC, 1988.

WILLIAMSON, O. E. The economics institutions of capitalism. New York, NY: The Free Press, 1985.

ZVEIBIL, V. Z. Reforma do estado e a gestão do saneamento: uma trajetória incompleta. 2003. 237 p. Tese (Doutorado em Saúde Pública). Escola Nacional de Saúde Pública, FIOCRUZ, Rio de Janeiro. 


\section{Anexo 1 - Roteiro da entrevista com os reguladores}

\section{Entrevista Oral}

Pergunta 1: Qual o papel da agência reguladora na universalização dos serviços? (Por quê?)

Objetivo: levantar a compreensão acerca do papel que a agência deveria assumir na universalização dos serviços.

Pergunta 2: Quais os mecanismos e iniciativas da sua agência reguladora sobre os prestadores de serviço visando ampliar ou incentivar o atendimento por água e esgoto, principalmente em relação às camadas mais carentes da população? (Como?)

Objetivo: levantar as ações e incentivos regulatórios em curso com vistas à universalização dos serviços de água e esgoto.

Pergunta 3: De que maneira os temas subsídios, eficiência, contratos de concessão e/ou programa, critérios de investimento são focados pela agência reguladora como ferramentas para universalização dos serviços?

Objetivo: levantar a opinião acerca de temas relevantes à universalização dos serviços.

Pergunta 4: De que forma o desenho de uma agência reguladora pode influenciar os objetivos de universalização da prestação dos serviços?

Objetivo: levantar a percepção sobre a influência do desenho da agência no objetivo de universalização dos serviços.

Pergunta 5: Que arranjos institucionais estão sendo realizados entre sua agência e estado/municípios para a regulação dos serviços em seu Estado?

Objetivo: levantar formas de arranjos institucionais para a regulação dos serviços.

Pergunta 6: Como viabilizar a regulação da prestação dos serviços de água e esgoto em seu Estado de forma a atender à Lei ${ }^{\circ} 11.445 / 2007$ ? 
Objetivo: levantar os desafios para viabilizar a regulação.

Pergunta 7: Que aspectos deveriam constar do marco regulatório estadual de saneamento básico para a universalização dos serviços?

Objetivo: levantar contribuições para formulação de marco regulatório de saneamento básico.

Pergunta 8: Quais os desafios para a formulação do marco regulatório em seu Estado?

Objetivo: levantar as dificuldades para formulação/implementação do marco regulatório de saneamento básico.

\section{Complementação da Entrevista Oral realizada por e-mail}

Pergunta 1: Como a agência se relaciona com os seguintes reguladores intersetoriais e que formas de cooperação poderiam ser estabelecidas para a regulação dos serviços de água e esgoto com estes reguladores: meio ambiente, defesa do consumidor, vigilância sanitária e recursos hídricos.

Objetivo: levantar as dificuldades e pontos convergentes para construção de cooperação intersetorial para regulação dos serviços de água e esgoto.

Pergunta 2: Quais os arranjos institucionais propostos pela agência para recebimento da delegação da regulação dos serviços de água e esgoto dos municípios? Quais os espaços de participação dos municípios no(s) arranjo(s) previstos para esta regulação?

Objetivo: levantar os principais aspectos dos modelos de recebimento da delegação da regulação da prestação dos serviços e as formas de participação dos municípios nos arranjos propostos.

Pergunta 3: Como a agência está participando do processo de negociação dos contratos de prestação dos serviços de água e esgoto? Qual o comportamento da agência em relação à concessionária e ao poder concedente? 
Objetivo: levantar formas de exercício do poder de recomendação da agência e seu comportamento diante dos atores do setor.

Pergunta 4: Qual a situação funcional (comissionados, concursados, provisórios, etc.) do quadro de pessoal da agência? Há evasão de quadros técnicos? Se sim, em que magnitude?

Objetivo: levantar a situação do quadro de pessoal da agência.

Pergunta 5: Em que aspectos da regulação em seu Estado há margem para atuação discricionária da agência que incentive melhoria de eficiência da concessionária regulada e da qualidade da prestação dos serviços? De que forma esta atuação é realizada?

Objetivo: levantar a atuação da agência dentro da margem de discricionariedade que o marco setorial lhe confere.

Pergunta 6: Qual seria a estrutura operacional adequada ou ideal de sua agência para regular os serviços de água e esgoto no Estado? O que falta para obtê-la? Objetivo: levantar as estruturas atual e futura para regulação dos serviços.

Pergunta 7: Qual a secretaria de Estado a que a agência está vinculada e qual justificativa desta vinculação? Se a agência foi vinculada a outras secretarias, favor citá-las.

Objetivo: levantar a localização institucional da agência dentro da estrutura do poder executivo.

Pergunta 8: Como obter eficácia na atividade regulatória mesmo diante da fragilidade ou ausência de mecanismos para punição de infrações pela concessionária?

Objetivo: levantar as dificuldades para atuação da agência diante da fragilidade do marco regulatório. 
Pergunta 9: Qual sua expectativa de evolução institucional da agência no médio e longo prazo? Quais seriam estes estágios e as principais dificuldades a serem vencidas?

Objetivo: levantar as perspectivas de evolução da agência no médio e longo prazo.

Pergunta 10: Quais deveriam ser os principais aspectos a serem considerados no futuro marco regulatório setorial do seu Estado?

Objetivo: levantar os principais pontos a serem contemplados no marco regulatório setorial do Estado. 